\title{
The Agency of Things in Medieval and Early Modern Art
}

\author{
Materials, Power and Manipulation
}

This volume explores the late medieval and early modern periods from the perspective of objects. While the agency of things has been studied in anthropology and archaeology, it is an innovative approach for art historical investigations. Each contributor takes as a point of departure active things: objects that were collected, exchanged, held in the hand, carried on a body, assembled, cared for or pawned. Through a series of case studies set in various geographic locations, this volume examines a rich variety of systems throughout Europe and beyond.

Grażyna Jurkowlaniec (PhD 2000, habilitation 2009) is assistant Professor at the Institute of Art History at the University of Warsaw. She specializes in art and artistic patronage between the thirteenth and sixteenth century in Europe. She has published in Zeitschrift für Kunstgeschichte, Konsthistorisk tidskrift and Artibus et Historiae.

Ika Matyjaszkiewicz (PhD candidate at the University of Warsaw) conducts a project for the Polish National Science Centre Painted Representations of the Volto Santo in the Light of Spatial Studies. Her research focuses on the relationship between the beholder and the work of art. Her publications concern medieval, modern and contemporary art.

Zuzanna Sarnecka (BA Cantab., MA Cantab. and London, PhD) is a lecturer in Art History at the University of Warsaw. Her doctoral thesis at the University of Cambridge focused on the devotional and artistic significance of glazed terracotta sculpture in the Marche. She has published in Artibus et Historiae and Arte Medievale. 


\section{Routledge Research in Art History}

Routledge Research in Art History is our home for the latest scholarship in the field of art history. The series publishes research monographs and edited collections, covering areas including art history, theory, and visual culture. These high-level books focus on art and artists from around the world and from a multitude of time periods. By making these studies available to the worldwide academic community, the series aims to promote quality art history research.

The Gamin de Paris in Nineteenth-Century Visual Culture

Delacroix, Hugo, and the French Social Imaginary

Marilyn R. Brown

Antebellum American Pendant Paintings

New Ways of Looking

Wendy N.E. Ikemoto

Expanding Nationalisms at World's Fairs

Identity, Diversity and Exchange, 1851-1915

Edited by David Raizman and Ethan Robey

William Hunter and his Eighteenth-Century Cultural Worlds

The Anatomist and the Fine Arts

Helen McCormack

The Agency of Things in Medieval and Early Modern Art

Materials, Power and Manipulation

Edited by Grażyna Jurkowlaniec, Ika Matyjaszkiewicz, Zuzanna Sarnecka

National Identity and Nineteenth-Century Franco-Belgian Sculpture

Jana Wijnsouw 


\section{The Agency of Things in Medieval and Early Modern Art Materials, Power and Manipulation}

Edited by Grażyna Jurkowlaniec, Ika Matyjaszkiewicz and Zuzanna Sarnecka 
First published 2018

by Routledge

711 Third Avenue, New York, NY 10017

and by Routledge

2 Park Square, Milton Park, Abingdon, Oxon OX14 4RN

Routledge is an imprint of the Taylor \& Francis Group, an informa business

(C) 2018 Taylor \& Francis

The right of Grażyna Jurkowlaniec, Ika Matyjaszkiewicz and Zuzanna Sarnecka to be identified as the authors of the editorial material, and of the authors for their individual chapters, has been asserted in accordance with sections 77 and 78 of the Copyright, Designs and Patents Act 1988.

The Open Access version of this book, available at www.taylorfrancis. com, has been made available under a Creative Commons Attribution-Non Commercial-No Derivatives 4.0 license.

Trademark notice: Product or corporate names may be trademarks or registered trademarks, and are used only for identification and explanation without intent to infringe.

Library of Congress Cataloging in Publication Data

A catalog record for this book has been requested

ISBN: 978-1-138-05422-6

ISBN: 978-1-315-16694-0

Typeset in Sabon

by Swales \& Willis Ltd, Exeter, Devon, UK 


\section{Contents}

Figures

vii

Acknowledgments xiii

Contributors xiv

Introduction 1

Art History Empowering Medieval and Early Modern Things 3

GRAŻYNA JURKOWLANIEC, IKA MATYJASZKIEWCZ, ZUZANNA SARNECKA

PART 1

Material Agency

1 The Power of Nature and the Agency of Art: The Unicorn

Cup of Jan Vermeyen

ANDREW MORRALL

2 Late Medieval Enclosed Gardens of the Low Countries:

Mixed Media, Remnant Art, Récyclage and Gender in the

Low Countries (Sixteenth Century Onwards)

BARBARA BAERT, HANNAH ITERBEKE, LIEVE WATTEUW

\section{PART 2}

The Power of Things

3 Knighted by the Apostle Himself: Political Fabrication and

Chivalric Artefact in Compostela,1332

ROSA M. RODRÍGUEZ PORTO

4 Agency and Miraculous Images

5 Agency, Beauty and the Late Medieval Sculptural Encounter 
vi Contents

PART 3

Objects as Social Agents

6 Dispersal, Exchange and the Culture of Things in Fifteenth-century Italy

LEAH R. CLARK

7 Michelangelo, Tommaso de' Cavalieri and the Agency of the Gift-Drawing

ALEXANDER LEE

8 Distributing Dürer in the Netherlands: Gifts, Prints, and the Mediation of Fame in the Early Sixteenth Century JAYA REMOND

PART 4

Agency of Physical Manipulations

9 The Early Modern Bible between Material Book and Immaterial Word

WIM FRANÇOIS

10 Diagnostic Performance and Diagrammatic Manipulation in the Physician's Folding Almanacs

KAREN EILEEN OVERBEY, JENNIFER BORLAND

11 Surgical Saws and Cutting-Edge Agency JACK HARTNELL

PART 5

The Agency of Things and Human Agency

12 The Boots of Saint Hedwig: Thoughts on the Limits of the Agency of Things JACQUELINE E. JUNG 


\section{Figures}

Cover Image: Anonymous, Panel from the Annunciation with the Unicorn Poliptych, c.1480-90, tempera on panel. Warsaw, Muzeum Narodowe w Warszawie, inv. no. Śr. 124. Photo: (C) Muzeum Narodowe w Warszawie.

Figure 1.1 Jan Vermeyen and Ottavio Miseroni, Unicorn Horn Cup, narwhal horn, diamonds, rubies, gold and enamel work.

Vienna, Kunsthistorisches Museum, Kunstkammer, inv. no. KK 1113. Photo: (C) KHM-Museumsverband. 18

Figure 1.2(a) Detail of Figure 1.1. 21

Figure 1.2(b) Detail of Figure 1.1. 21

Figure 1.3 Workshop of Ottavio Miseroni, Minerva [commesso:

Giovanni Ambrogio(?), mount: Jan Vermeyen], agate, jasper, silver gilt, rubies, white enamel. Vienna, Kunsthistorisches Museum, Kunstkammer, inv. no. ANSA XII 819. Photo:

(C) KHM-Museumsverband.

Figure 1.4 Nikolaus Pfaff, Covered Cup, rhinoceros horn, warthog tusks, fossilized shark's tooth, silver gilt, partially painted in cold colors, 1611. Vienna, Kunsthistorisches Museum, Kunstkammer, inv. no. KK 3709. Photo:

(C) KHM-Museumsverband.

Figure 1.5 Detail of Figure 1.4.

Figure 1.6 Isaac de Pleyère, Relation de Groenland (Paris: Augustin Courbé: 1647), fol. 145.

Figure 2.1 Anonymous, Enclosed Garden with Calvary and Hunt on the Unicorn, mixed media, 1510-20. Mechelen, Museum Hof van Busleyden. Photo: (C) KIK-IRPA, Brussels.

Figure 2.2 Anonymous, View of the Court Béguinage of St. Catherine in Mechelen, oil on paper, 1500-1600. Mechelen, Museum Hof van Busleyden. Photo: (C) KIK-IRPA, Brussels.

Figure 2.3 Anonymous, Skull Relic of Herkenrode, mixed media, 1400-1800. Hasselt, Sint-Quintinuskathedraal. Photo: (C) KIK-IRPA, Brussels.

Figure 2.4 Anonymous, Enclosed Garden with Calvary and Hunt on the Unicorn (X-Ray), mixed media, 1510-20. Mechelen, Museum Hof van Busleyden. Photo: C KIK-IRPA, Brussels. 
viii Figures

Figure 3.1 The statue of Santiago del Espaldarazo is arranged for display in the exhibition Santiago: A orixe. Santiago de Compostela, Cidade da Cultura. Photo: (C) Fundación Cidade da Cultura de Galicia/Manuel G. Vicente.

Figure 3.2 Santiago del Espaldarazo. Monasterio de Las Huelgas de Burgos. Photo: Eloy García Quevedo, Exposición de Arte Retrospectivo de 1921. By kind permission of the Instituto de Enseñanza Secundaria Conde Diego de Porcelos, Burgos.

Figure 3.3 Cartulary of the Hospital of St Jacques of Tournai, c.1489. Tournai, Bibliothèque de la Ville, Tournai MS 27, fol. 1r (detail). Photo: (C) Bibliothèque de la Ville de Tournai.

Figure 3.4 Tumbo B of the Cathedral of Santiago de Compostela, c.1326. Archivo-Biblioteca de la Catedral de Santiago de Compostela, fol. 2v (ACS, CF, 33). Photo:

(C) Cabildo de la Catedral de Santiago de Compostela.

Figure 3.5 Second seal of Béranger of Landore. Archivo de la

Catedral de Salamanca. Photo from: Santiago, Camiño de Europa: culto e cultura na peregrinación a Compostela, exhib. cat., Santiago, Mosteiro de San Martiño Pinario, July-September, 1993 (Santiago de Compostela: Xunta de Galicia, 1993), 436.

Figure 5.1 Male torso from Miletus, marble, c.480-470 BCE. Paris, Musée du Louvre. Photo: (C) RMN-Grand Palais (Musée du Louvre)/Hervé Lewandowski.

Figure 5.2 Marco Romano, Crucifix, detail, polychromed wood, second decade of the fourteenth century(?). Colle di Val d'Elsa, Museo Civico e Diocesano. Photo: Author.

Figure 5.3 Italian sculptor, Crucifix, polychromed wood, fourteenth century. Naples, Santa Maria di Constantinopoli. Photo: Author.

Figure 5.5 Giovanni Pisano, Crucifix, polychromed wood, c.1300. Pisa, San Nicola. Photo: Author.

Figure 5.6 Detail of Figure 5.5. Photo: Author.

Figure 6.1 Montalto Reliquary, front and back with inscriptions. Montalto delle Marche, Museo Diocesano. Photo: (C) Museo Sistino di Montalto Marche.

Figure 6.2 Entry from Archivio di Stato di Modena, Amministrazione dei Principi 638 7R. Photo: (C) Archivio di Stato di Modena.

Figure 6.3 Detail of memento mori message on cover of Archivio di Stato di Modena, Amministrazione dei Principi 638. Photo: (C) Archivio di Stato di Modena. 
Figure 8.1 Albrecht Dürer, Saint Jerome in His Study, engraving, 1514. Berlin, Kupferstichkabinett, Staatliche Museen, inv. no. 401-2. Photo: (C) Kupferstichkabinett, Staatliche Museen zu Berlin.

Figure 8.2 Albrecht Dürer, Adam and Eve, engraving, 1504. Berlin, Kupferstichkabinett, Staatliche Museen zu Berlin, inv. no. 101-1893. Photo: (C) Kupferstichkabinett, Staatliche Museen zu Berlin.

Figure 9.1 El nuevo testamento de nuestro Redemptor y Salvador Iesu Christo . . ., trans. Francisco de Enzinas ([Antwerp: Steven Mierdmans], 1543). Brussels, Koninklijke Bibliotheek van België, LP 28636. Photo: (C) Koninklijke Bibliotheek van België.

Figure 9.2(a) De Bibel Tgeheele Oude ende Nieuwe Testament ... and 9.2(b) (Antwerp: Willem Vorsterman, 1528) and Tgeheele Nieu Testament... (Antwerp: Willem Vorsterman, 1529). Leuven, KU, Maurits Sabbe Library, GBIB P22.055.1/F\%/BIJB/1528-29.

Figure 9.3 De Bibel inhoudende het oude ende nyeuwe Testament..., trans. Nicholas van Winghe (Antwerp: Widow Henrick Peetersen van Middelburch for Marie Ancxt, 1560). Leuven, KU, Maurits Sabbe Library, GBIB P22.055.1/F\% BIJB/1560.

Figure 9.4 Den Bibel Tgeheele Oude ende Nieuwe Testament . . . (Antwerp: Willem Vorsterman, 1533-4). Leuven, KU, Maurits Sabbe Library, GBIB P22.055.1/F/BIJB/1533-34.

Figure 9.5 Den Bibel Tgeheele Oude ende Nieuwe Testament . . . (Antwerp: Willem Vorsterman, 1533-4). Leuven, KU, Maurits Sabbe Library, GBIB P22.055.1/Fo/BIJB/1533-34.

Figure 9.6 Die Bibel, wederom met grooter nersticheit oversien ende gecorrigeert ...., trans. Alexander Blanckart and Joannes Sprengel (Cologne: Jasper van Gennep, 1547-8), front page. Leuven, KU, Maurits Sabbe Library, GBIB P22.055.1/F/BIJB/1548.

Figure 9.7 Het nieu testament onses Heeren Iesu Christi met korte uytlegghinghen ..., ed. Franciscus Costerus (Antwerp: Ioachim Trognaesius, 1614). Leuven, KU, Maurits Sabbe Library, GBIB P225.055.1/F COST Nieu 1614.

Figure 10.1 Folding Physician's Almanac, showing structure of folded folios with leather cover, England, fifteenth century. Oxford, Bodleian Library, MS Ashmole 6. Photo: K. E. Overbey; reproduced with permission of the Bodleian Library. 
$\mathrm{x}$ Figures

Figure 10.2 Charts of solar and lunar eclipses Almanach, tabula festorum, mobilium ab anno 1364 usque annum domini 1462, York, England, between 1406 and 1424. Philadelphia, The Rosenbach, MS 1004/29, fol. 7. Photo: J. Borland.

Figure 10.3 Table of planetary hours. Oxford, Bodleian Library, MS Rawlinson D928. Photo: K. E. Overbey; reproduced with permission of the Bodleian Library.

Figure 10.4 St Margaret emerging from the Dragon. Vie de Sainte Marguerite, France, probably Paris, 1491. New York, The Pierpont Morgan Library, MS M.1092, Recto. Photo: (C) The Pierpont Morgan Library, New York.

Figure 10.5 Martyrdom of St Edmund. Wall painting at St Andrew's Church, Stoke Dry, Rutland. Photo: Amanda Slater, licensed under CC BY-SA 2.0 (https://creativecommons.org/ licenses/by-sa/4.0/legalcode). Original photograph has been cropped and adjusted for color.

Figure 11.1 Attributed to the Master of Los Balbases, Saints Cosmas and Damian Performing the Miracle of the Transplanted Leg, oil on wooden board, c.1495. Wellcome Collection, London. Photo supplied by Wellcome Collection, licensed under [CC-BY / CC-BYNC].

Figure 11.2 Anonymous, The Leg Amputation of Friedrich III, watercolour on paper, c.1493. Vienna, Graphische Sammlung Albertina, Min. 22475. Photo: (C) Albertina, Vienna

Figure 11.3 Four surgical saws, iron, steel, and gilded details with wooden or metal handles, late fifteenth and sixteenth centuries. London, Wellcome Collection (long-term loan from Science Museum, Hamonic Collection), object numbers (clockwise from upper-left): A241432, A121436, A135416, A121431. Photo supplied by Wellcome Collection, licensed under [CC-BY / CC-BYNC].

Figure 11.4 Detail of the handle of a bow-frame amputation saw, steel and ebony with inset reflective eyes. London, Science Museum, Hamonic Collection, object number A135416. Photo: Author.

Figure 11.5 Frontispiece to Walther Ryff, Gross Chirurgei oder volkommene Wundartznei (Frankfurt: Christian Egenolff, 1559). London, Wellcome Library, EPB/D 5677/D. Photo supplied by Wellcome Collection, licensed under [CC-BY / CC-BYNC].

Figure 11.6 Anatomical instruments displayed on a table, including an amputation saw, Andreas Vesalius, De Humani Corporis Fabrica, reproduced from the original 1543 volume by Franciscius \& Criegher in Venice, 1568. Heidelberg, Universitätsbibliothek, urn:nbn:de:bsz:16-diglit-129406. Photo supplied by Wellcome Collection, licensed under [CC-BY / CC-BYNC]. 
Figure 12.1 Vita beatae Hedwigis (Hedwig Codex), Silesia, 1353, fol. 12v: St Hedwig with Duke Ludwig of Liegnitz and Duchess Agnes. Los Angeles, J. Paul Getty Museum, Ludwig XI 7. Photo: (C) J. Paul Getty Museum

Figure 12.2 Vincent Van Gogh, A Pair of Shoes, 1886. Amsterdam, Van Gogh Museum. Photo: (C) Album/Art Resource, New York.

Figure 12.3 Three medieval shoes and the problems they caused to feet. Photo from: Francis Grew and Margrethe de Neergaard, Shoes and Pattens. Medieval Finds from Excavations in London: 2, rev. edn (Woodbridge: Boydell, 2001), 109.

Figure 12.4 Hedwig Codex, Silesia, 1353, fol. 64v: A hanged man is release thanks to Hedwig's intervention (top); a woman who has worked a mill on a Sunday appeals to Hedwig to loosen her hands from her tool (bottom). Los Angeles, J. Paul Getty Museum, Ludwig XI 7. Photo: (C) J. Paul Getty Museum.

Figure 12.5 Hedwig Codex, Silesia, 1353, fol. 24v: A crucifix speaks to Hedwig during prayer (top); Hedwig cleanses herself and her grandchildren with the water nuns used to wash their feet (bottom). Los Angeles, J. Paul Getty Museum, Ludwig XI 7. Photo: (C) J. Paul Getty Museum.

Figure 12.6 Hedwig Codex, Silesia, 1353, fol. 38v: Hedwig crawls barefoot to church through the snow, leaving bloody footprints behind (top); Hedwig flagellates herself, then has an attendant continue the process (bottom). Los Angeles, J. Paul Getty Museum, Ludwig XI 7. Photo: (C) J. Paul Getty Museum.

Figure 12.7 Hedwig Codex, Silesia, 1353, fol. 46r: Hedwig's hand freezes in place as she listens to scripture during dinner (top); Hedwig levitates and glows while she prays (bottom). Los Angeles, J. Paul Getty Museum, Ludwig XI 7. Photo: (C) J. Paul Getty Museum.

Figure 12.8 Hedwig Codex, Silesia, 1353, fol. 24r: Hedwig kisses the nuns' choir stalls in the Trzebnica convent (top), kisses the stairs to their dormitories and their used handtowels (bottom). Los Angeles, J. Paul Getty Museum, Ludwig XI 7. Photo: (C) J. Paul Getty Museum.

Figure 12.9 Hedwig Codex, Silesia, 1353, fol. 38r: Hedwig's normally bare feet are miraculously shod when her husband surprises her in her chamber (top); Hedwig demonstrates to her confessor how she has 'worn' the shoes he gave her (bottom). Los Angeles, J. Paul Getty Museum, Ludwig XI 7. Photo: (C) J. Paul Getty Museum.

Figure 12.10 Sculpture of St Bartholomew, wood with polychromy, southern Germany or Switzerland, c.1470. Fribourg (Switzerland), Musée d'art et d'histoire. Photo: Author. 


\section{xii Figures}

Figure 12.11 Hedwig Codex, Silesia, 1353, fol. 46v: Hedwig converses with her chaplain (top); Hedwig prays at altar of Trzebnica convent church holding ivory statuette and gives the statuette to others to kiss (bottom). Los Angeles, J. Paul Getty Museum, Ludwig XI 7. Photo: (C) J. Paul Getty Museum.

Figure 12.12 Hedwig Codex, Silesia, 1353, fol. 82v: Hedwig is attended by saints on her deathbed (top), then breathes her last in the presence of nuns (bottom). Los Angeles, J. Paul Getty Museum, Ludwig XI 7. Photo: (C) J. Paul Getty Museum.

Figure 12.13 Hedwig Codex, Silesia, 1353, fol. 87r: Hedwig is liturgically commemorated (top) and prepared for burial (bottom). Los Angeles, J. Paul Getty Museum, Ludwig XI 7. Photo: (C) J. Paul Getty Museum.

Figure 12.14 Hedwig Codex, Silesia, 1353, fol. 137v: Hedwig is exhumed (top) and her relics processed into church at her canonization in 1267 (bottom). Los Angeles, J. Paul Getty Museum, Ludwig XI 7. Photo: (C) J. Paul Getty Museum. 


\section{Acknowledgments}

This volume is the final outcome of the research project Agency of Things. New Perspectives on European Art of the Fourteenth-Sixteenth Centuries, supported by the National Science Centre, Poland (no 2013/09/B/HS2/01444).

Our deepest gratitude goes to Antoni Ziemba and Kamil Kopania, our co-investigators in The Agency of Things project, for all the stimulating discussions that nourished this book. We would like to stress Antoni's role in forging close links between the National Museum and the University of Warsaw which ensured that artistic objects were always at the heart of our investigations. The selection of the papers presented to the reader in this volume directly corresponds with the shared interests and issues that occupied the entire team at the University of Warsaw for the past three years.

For generously granting us the opportunity to host the two-day conference in June 2015 in the unique setting of the National Museum in Warsaw, we are immensely grateful to Director Agnieszka Morawińska. She provided the intellectual support for the project and facilitated our research of the museum's collection in every possible way. We hope that the cover of this volume which shows one of the National Museum's treasures becomes a visible token of our gratitude.

We would also like to thank our friends and colleagues, who have helped with the planning and the smooth organisation of the conference in Warsaw, most importantly Patrycja Misuda-Ramlau, Magdalena Herman and Jakub Bendkowski. Our special thanks go to Zofia Herman and Jakub Adamski for chairing during the conference and holding a brilliant session for our guests and speakers in the Medieval Gallery of the National Museum.

We are grateful to all speakers and contributors for sharing freely with us their views on the issue of agency. The conference and work on this volume gave us an invaluable opportunity to discuss key aspects of the theoretical framework through the lens of new case studies and cutting-edge research. Stimulating discussions confirmed some of our preliminary hypotheses, while at times they encouraged us to rethink or indeed abandon other concepts.

Finally, thanks to Isabella Vitti and the Routledge editorial team for carrying our book project forward and publishing this volume. 


\section{Contributors}

Barbara Baert is a Professor in Art History at the University of Leuven, Belgium. She studied art history and philosophy at the Catholic University of Leuven and at the Università degli Studi in Siena. She is the founder of the Iconology Research Group, a European network for the research into the analysis of images. She has published in various journals on sacred topography, the theory of images and relics and gender iconography. Her recent publications include: Caput Johannis in Disco. Essay on a Man's Head (Brill Publishers, 2012), The Woman with the Bloodflow. Narrative, Iconic and Anthropological Spaces (Leuven-Peeters 2014), Nymph. Motif, Phantom, Affect. A Contribution to the Study of Aby Warburg (Leuven-Peeters, 2014) and Pneuma in the Middle Ages and the Early Modernity (Leuven-Peeters, 2016). She was awarded with the prestigious Francqui Prize in 2016 for her important interdisciplinary contributions to the Human Sciences.

Jennifer Borland is Associate Professor of Art History at Oklahoma State University. Her research and scholarship have been concerned with medieval medical and scientific imagery, medievalism and collecting, materiality, the corporeal experience of objects and spaces, and audience and reception. Her publications include 'Freeze-framed: theorizing the historiated initials of the Régime du corps', Word o Image 32.2 (April-June 2016), 235-50; 'Unruly Reading: The Consuming Role of Touch in the Experience of a Medieval Manuscript', in Scraped, Stroked, and Bound: Materially Engaged Readings of Medieval Manuscripts, ed. Jonathan Wilcox (Turnhout: Brepols, 2013), 97-114, plates 225-30; and 'Encountering the Inauthentic', in Transparent Things: A Cabinet, ed. Karen Eileen Overbey and Maggie M. Williams (New York: punctum books, 2013), 17-38. She is currently completing a book about the illustrated manuscripts of Aldobrandino of Siena's Régime du corps, a late-medieval health guide. Jennifer is a founding member of the Material Collective (thematerialcollective.org).

Leah R. Clark is a Lecturer in Art History at the Open University. She holds an MA from the Courtauld Institute of Art and a PhD from McGill University, Montreal. Her research explores the roles objects play in creating networks in the fifteenth century through their exchange, collection and replication. She is presently completing a book manuscript (Objects and Exchanges: Circulation, Replication, and Association in the Italian Courts (1450-1500)), and has started on a new book project, which explores objects and materials in cross-cultural exchanges through three key themes - touch, transfer and translation. She has recently co-edited (with Nancy Um) a special issue of the Journal of Early Modern History, 'The Art of 
Embassy: Objects and Images of Early Modern Diplomacy' (2016). Her work has been published in a range of edited volumes and journals, including the Journal of the History of Collections. She has received awards and fellowships from a number of institutions including the Social Sciences and Humanities Research Council of Canada, the Italian government and the British Academy.

Peter Dent (PhD, Art History, the Courtauld Institute of Art) is a Senior Lecturer in Art History in the Department of History of Art, University of Bristol. He wrote his doctoral thesis (also at the Courtauld) on representations of the body of Christ in fourteenth-century Tuscan sculpture (2005). He has since held research fellowships from the British Academy, the Henry Moore Foundation and the Leverhulme Trust. He edited the collection Sculpture and Touch (Ashgate, 2014) and is currently one of the editors of the Sculpture Journal.

Wim François is a Research Professor of the Special Research Fund of the KU Leuven. $\mathrm{He}$ is a member of the Research Unit of History of Church and Theology. His field of research is the history of Church and Theology in the Early Modern Era (1450-1650). He is investigating the place of vernacular Bible reading in the life of the faithful in the period concerned. In addition, he is doing research into the Bible commentaries edited by the Louvain and Douai theologians during the Golden Age of Catholic biblical scholarship (1550-1650), with a particular focus on the Augustinian inspiration of the aforementioned commentaries. He is also involved in the Biblia Sacra Research Group, a network of researchers investigating the Bible in the late Middle Ages and the Early Modern Era. His recent publications include: The Reception of Trent's Regula Quarta (1564) and Vernacular Bible Reading in the Low Countries (2015), 'The Compositors' Neglect' or the True Story Behind the Prohibition of Vorsterman's Dutch Bibles (2015), Augustine's Heritage in Late Medieval Biblical Scholarship (2014), The Catholic Church and Vernacular Bible Reading, Before and After Trent (2013) and Erasmus van Rotterdam, De bijbel voor boer, smid en steenkapper (2012).

Jack Hartnell is a Lecturer in the History of Art at the University of East Anglia where his research focuses on the visual cultures of science, medicine, mathematics and cartography in the later Middle Ages and early Renaissance. He has previously held fellowships at Columbia University, the Courtauld Institute of Art, the MaxPlanck-Institut für Wissenschaftsgeschichte, and the Victoria and Albert Museum. His recent and forthcoming work includes articles on medieval anatomical practice, medical instrumentation and the surgical image of the 'Wound Man', as well a book on medieval scrolls and an introduction to medieval medicine and art entitled Medieval Bodies (Wellcome Publishing and Profile Books, 2017).

Hannah Iterbeke is Junior Researcher at Illuminare - Centre for the Study of Medieval Art (KU Leuven). She completed her Master's in Art History at the University of Leuven with a thesis entitled 'Devotion to the Silk Flower: The Making and Meaning of Silk Flowers in Sixteenth-Century Enclosed Gardens of Northern Europe' under the supervision of Professors Barbara Baert and Lieve Watteeuw. Currently she is working on a doctoral dissertation entitled 'Multiplied Sculpture, Multifarious Devotion: The Enclosed Gardens and the Production, Circulation and Function of 'Moderate' Images in the Low Countries (1450-1600)' under the supervision of Professor Baert. 
Jacqueline E. Jung is Associate Professor in the History of Art Department at Yale University where she teaches on medieval European art and architecture. Her recent publications include 'The Tactile and the Visionary: Notes on the Place of Sculpture in the Medieval Religious Imagination' (2010); 'Moving Viewers, Moving Pictures: The Portal as Montage on the Strasbourg South Transept' (2015); and 'The Portal from San Vicente Martír in Frías: Sex, Violence, and the Comfort of Community in Thirteenth-Century Sculpture Program at The Cloisters' (2015). Her book The Gothic Screen: Space, Sculpture, and Community in the Cathedrals of France and Germany (Cambridge University Press, 2013) received the PROSE Award for Art History and Criticism from the Association of American Publishers, and was a finalist for the College Art Association's Charles Rufus Morey Prize. She has been honoured with fellowships from the Metropolitan Museum of Art and the American Academy in Berlin, and most recently with the Prize of the Aby-Warburg Foundation in Hamburg. A new book, titled Eloquent Bodies: Movement, Expression, and the Human Figure in Gothic Sculpture, will be published by Yale University Press.

Alexander Lee is a Fellow in the Centre for the Study of the Renaissance at the University of Warwick. He holds degrees from the universities of Cambridge and Edinburgh, and has previously held posts at the University of Oxford, the Universite du Luxembourg and the Università degli studi di Bergamo. His recent publications include The Ugly Renaissance (London: Hutchinson, 2013) - a Times Literary Supplement 'Book of the Year 2013' - and Petrarch and St. Augustine: Classical Scholarship, Christian Theology, and the Origins of the Renaissance in Italy (Leiden: Brill, 2012). He is also the co-editor of Renaissance? Perceptions of Continuity and Discontinuity in Europe, c.1300-c.1550 (Leiden: Brill, 2010) and Libertés et citoyenneté urbains $d u$ moyen âge à nos jours (Trier and Luxembourg: CLUDEM, 2015). He is currently completing a monograph for Oxford University Press entitled Humanism and Empire: The Imperial Ideal in Fourteenth-Century Italy, and a biography of Niccolò Machiavelli to be published by Macmillan in autumn 2017.

Robert Maniura is a Senior Lecturer at Birkbeck, University of London. He studied the history of art at the Courtauld Institute, taking his PhD in 1998. He has held Fellowships at Villa I Tatti, the Harvard University Center for Italian Renaissance Studies, and the Netherlands University Art History Institute in Florence. He joined Birkbeck in 2001 where his work has been supported by a British Academy MidCareer Fellowship and a Leverhulme Trust Research Fellowship. His recent research has concentrated on the role of the visual in devotion in the late Middle Ages and Renaissance, with a special focus on images associated with miracles. His book, Art and Miracle in Renaissance Tuscany, is forthcoming with Cambridge University Press. His other publications include: Pilgrimage to Images in the Fifteenth Century: The Origins of the Cult of Our Lady of Czestochowa (Woodbridge: Boydell and Brewer, 2004); 'Two Marian Image Shrines in Fifteenth-Century Tuscany, the "Iconography of Architecture" and the Limits of "Holy Competition", in Architecture and Pilgrimage 1000-1500: Southern Europe and Beyond, ed. by Paul Davies, Deborah Howard and Wendy Pullan (Aldershot: Ashgate 2013); 'Image and Relic in the Cult of Our Lady of Prato', in Images, Relics, and Devotional Practices in Medieval and Renaissance Italy, ed. by S. J. Cornelison and S. B. Montgomery, (Tempe: Arizona Center for Medieval and Renaissance Studies, 2005). 
Andrew Morrall is Professor at the Bard Graduate Center, New York. He has written on the arts of early modern Northern Europe, art and the Reformation, the history of collecting, the intersections of art and science, theories of ornament and the early modern domestic interior. His publications include: Jörg Breu the Elder: Art, Culture and Belief in Reformation Augsburg (Ashgate, 2002) and (with Melinda Watt): 'Twixt Art and Nature': English Embroidery from The Metropolitan Museum of Art, 1580-1700 (Yale, 2008). Recent publications include: 'Die Rezeption Dürers und seiner Kunst im Venedig des frühen sechzehnten Jahrhunderts', in Albrecht Dürer. Seine Kunst im Kontext Ihrer Zeit (Städel Museum, Frankfurt-am-Main, 2013); and 'Object, Material, Myth: Ovidian Poetics and Natural Philosophy in the Sixteenth-Century Northern European Kunstkammer', in The Challenge of the Object (Nuremberg: Germanisches Nationalmuseum, 2013). His current research focuses on works of art and craft made for the sixteenth-century Kunstkammer.

Karen Eileen Overbey is Associate Professor of Art History at Tufts University. Her area of specialisation is medieval Britain and Ireland and her research focuses on portable objects and their uses in ritual and performance. She is the author of Sacral Geographies: Saints, Shrines, and Territory in Medieval Ireland (2012) and co-editor of The Bayeux Tapestry: New Interpretations (2009), Transparent Things (2013) and 'Active Objects' (2014), a special issue of the journal Different Visions. Her recent and forthcoming essays include: 'Decorative Arts' for the Oxford Bibliographies in Medieval Studies; a co-written essay on the critical methodologies of the 'materialist turn' in art history; an article on a thirteenthcentury rock crystal reliquary pendant; and a study of clothing relics in early Ireland and Anglo-Saxon England. Karen has served as a Director on the Board of the International Center of Medieval Art and is a founding member of the Material Collective (thematerialcollective.org).

Jaya Remond is currently a postdoctoral research fellow at the Max Planck Institut für Wissenschaftsgeschichte in Berlin. She holds a PhD in the history of art from Harvard University, and is presently completing a monograph on art primers in Northern Europe during the long sixteenth century. Her research investigates the creation and circulation of artistic knowledge as well as questions of pictorial literacy at the intersection of art and science in the early modern period. She has also begun work on a new research project, which explores the production of botanical imagery in Northern Europe c.1500-1750, with a focus on the representation of exotic plants. She has received grants and fellowships from the Graduate School of Arts and Sciences at Harvard University, the Kress Foundation, the Germanisches Nationalmuseum in Nuremberg, the Deutsches Forum für Kunstgeschichte in Paris and the Gerda Henkel Stiftung.

Rosa M. Rodriguez Porto is Postdoctoral Research Fellow at the Centre for Medieval Literature at the Universities of York and Southern Denmark. She received her PhD in Art History from the University of Santiago de Compostela with a dissertation on the illuminated books made for the kings and queens of Castile (1284-1369). Several grants and fellowships have allowed her to expand her research at the Warburg Institute, the Institut de Recherche et d'Histoire des Textes, the Amsterdam School for Cultural Analysis and St John's College, Cambridge. Her publications include 
articles on medieval Iberian courtly culture, artistic production and exchange in frontier societies, the Classical tradition in the Middle Ages and the uses of images in the construction of historical discourse.

Lieve Watteeuw is a Lecturer in the Art History and the History Department at KU Leuven (Technology and Laboratory Methods, Illuminated Manuscripts \& Codicology) and is library heritage researcher in the Faculty of Theology. From 2008 to 2012 she coordinated the Anjou Bible Research Project and is curator of the exhibition 'The Anjou Bible. Naples 1340, a Royal Manuscript Revealed in Museum M, Leuven'. In 2013 she published with Catherine Reynolds the Catalogue of Illuminated Manuscripts of the Museum Plantin-Moretus, Antwerp and curated the exhibition 'Magnificent Middle-Ages' in the same Museum. Current research projects are the Leuven-Louvain Illuminations Catalogue, the Missal from Berchem and the Manuscript from Sawalo (Museum Mayer van den Bergh, Antwerp). She is coordinating the research topics in the conservation project of the 'Enclosed Gardens' of Mechelen, a master project in the context of the forthcoming 'In Search of Utopia' exhibition in 2016. 


\section{Introduction}





\title{
Art History Empowering Medieval and Early Modern Things
}

\author{
Grażyna Jurkowlaniec, Ika Matyjaszkiewicz \\ and Zuzanna Sarnecka
}

It might seem that art history has always been focused on things. Admittedly, in the twentieth century, Conceptualism challenged the 'object-centred' notion of the work of art, but all ancient sculptures, medieval illuminated manuscripts, early modern portraits, modern buildings and even contemporary installations are material objects. However, the practice of art history usually proves focused not so much on objects, as on humans involved in the processes of production and reception of art: artists, patrons and beholders.

Pliny gave innumerable accounts of ancient painters and carvers, providing a model for subsequent artistic historiographers. This focus on humans remains clear, even though his Natural History is arranged according to different materials, which proves a certain sensitivity towards the physical aspects of things. When writing about bronze, he described first its properties, then the various kinds of objects produced from it, and only subsequently he dealt with sculptors famous for their works in that medium. Also Vasari paid attention to the material aspects of artistic production, as testified by the Introduction to the Three Arts of Design, Architecture, Sculpture and Painting, which prefaced his famous Vite. However, despite this apparent material interest, artists and their patrons constituted the primary focus of Vasari's account. Following the historiographer from Arezzo, generations of art lovers and art historians constructed the anthropocentric story of art. What resulted was a discipline apparently able to consider artworks solely in relation to stylistic development within a single oeuvre or 'school'. In turn, this approach brought about the necessity of value judgment and insisted on the notion of the artistic canon. Not accidentally, Vasari chose to describe solely 'the most excellent' artists, whose supreme creations were distinguished from ordinary, everyday things. This limited approach to the study of cultural artefacts created a particular challenge for scholars of medieval art, who, while working with a few documented names, often went to great lengths to attribute every piece to a specific author. Names such as the Master of Playing Cards are testimonies to the desperate attempts to reconstruct specific identities behind every artwork.

Building on the importance of 'schools', iconology opened new research possibilities for deciphering the 'disguised' meanings in a work of art. This method put an emphasis on a single artistic or patron's intention to convey in a work of art a culturally specific message. Erudite interpretations reduced pictures to signs or symptoms, ignoring their material character. On the other hand, studies of the reception of an artwork and the relationship between the image and its artistic medium provided an alternative interpretative strand. At the same time, questions about a function of an image became instrumental in studies of the late medieval and early modern art. Finally, 
art historical writings began to focus on objects and their active role, especially in religious practices.

The fruitful suggestion that artworks can be discussed from different perspectives beyond the merely aesthetic, symbolic, contextual and/or intertextual offered a possibility to explore their agency. The division into high and decorative arts was challenged by the realisation that artworks had a great efficacy and were not merely passive objects to look at but ones that could, under specific conditions, 'stare back'. ${ }^{1}$ Sharing the increased interest among historians of science, art historians similarly began to investigate the particular properties of materials and processes of production. ${ }^{2}$ Such an approach allowed the discussion of objects that had previously been omitted from any consideration because they fell outside specific stylistic or functional categories. This brought a realisation of greater continuity in the lives of things through the centuries, which challenged the established periodisation. ${ }^{3}$ Crucial for those changes in art historical studies were catalogues of exhibitions, which through carefully selected 'star objects' created new, inclusive narratives. ${ }^{4}$ The consideration of specific spaces, be it a public street, church interior or a private home revealed the active network of various things, places and people rather than a series of static, immutable stuff.

This volume is the final outcome of the research project Agency of Things: New Perspectives on European Art of the Fourteenth-Sixteenth Centuries. The project shows the perspectives opened up by the methodologies and theories elaborated over the course of three decades in the humanities and social sciences, from the performativity and 'material turn', through 'actor-network theory' and 'object-oriented ontology' to the 'agency of art'. The contributions assembled in this volume offer an innovative insight into this ongoing debate.

The theory of agency of things came about as a result of various shifts in Western humanities which have occurred since the late 1970s. In opposition to textualism, narrativism and postructuralism, which portrayed world and culture as a series of signs, the material and performative turns wanted to break away from equating world with text, and instead stressed the importance of active, embodied actors shaping reality. ${ }^{5}$ In performance studies historians and sociologists began to use the notion of agency to describe the intrinsically human ability to shape the surrounding social and material realities. Agency was associated with self-awareness and was seen as characteristic of individuals. Every human entity was perceived as a strong, active, influential subject which contributed to the formulation of its own system. Sociology (Pierre Bourdieu, Anthony Giddens) explored agency to describe the relationship between an individual and a structure. The applicability of the theory allowed the inclusion of individual intentionality into the discourse. Still, it did not exclude the active force and subjectivity of a community and of a social system itself. ${ }^{6}$ On the other hand, performativity in sociology and human sciences stressed the importance of everyday practices, processes, events and actions. Such framing of the social and cultural processes prompted the recognition of the physicality of active entities and materiality of the world in which performative acts occur. Thus the studies on performativity began to explore the posthumanist question about the ways in which 'matter matters' ${ }^{7}$

The 'material turn' allowed complex definitions of agency to be devised, insisting on the active role of artefacts in the forging and functioning of social structures. This was most apparent in actor-network theory (ANT). ${ }^{8}$ According to ANT materiality and sociality are two aspects of the same process of constructing the collective. Bruno Latour emphasised that collectivity, unlike society, is formed by both human 
and non-human actors. In the actor-network theory they become equal participants since the actor is defined as an entity capable of forging new relations or one 'that more or less successfully defines and builds a world filled by other entities with histories, identities, and interrelationships of their own'. ${ }^{9}$ While ANT does not propose any hierarchy of actors, undoubtedly the most significant are humans, texts, artefacts and money. The analysis of the network reveals that every human action may be intercepted and transformed by other actors. Consequently, the non-human actants are not merely tools, or intermediaries, employed to fulfil human intention, but instead they become mediators, always modifying the initial objective. The empirical study of the changes which occur within the networks is the only way to define these factors. ${ }^{10}$ ANT had the strongest impact on the studies of material culture undertaken by anthropologists and archaeologists. These fresh attempts placed an emphasis on micro-historical enquiries, drawing attention to the everyday life of an individual surrounded by material things. This spurred a vivid interest in an experience-based and sensory approach to scientific investigation, as well as directing attention to the category of change. At the turn of the twenty-first century, humanities began to engage with anti-anthropocentricism, which promoted the research of non-human entities, most importantly things and animals.

This theory was fruitfully explored in archeology, for instance by Chris Gosden and Bjørnar Olsen. They defined posthumanism as the turn to things and to the analysis of their agency. On the basis of various archaeological finds, Gosden explored the generative role in stylistic changes of a group of objects, which represent a certain type. Those shifts span over several generations and therefore cannot be justified by an individual human activity, but rather are caused by the things themselves. Thus style remains independent of particularised intentionality. Gosden takes into account also the physical aspect of stylistic transitions. The use of a group of objects became a source of a sensory experience shared among members of an entire community in which those objects functioned. Consequently, the interaction with those things shapes long-lasting models of social behaviour, which transcend the duration of any individual life. Humans and societies become subordinate to the active power of objects. ${ }^{11}$ Bjørnar Olsen made similar observations about material and somatic aspects of the collective memory. Rituals that form social events can be organised and performed only because of their entanglement with material artefacts which permit the temporal public reception. As Olsen asserts 'the persistency of the material world during periods of discontinuity of human bodily action is also a holding-readiness, a material Parathaltung for recovering or reenacting bodily memories and the "communal rhythm"'. ${ }^{12}$ This consideration of the inherent properties of things helps us to understand the unique function of the work of art. Gosden's discussion of style is similarly inspiring for art historians. This crucial art historical concept was illuminated also by anthropologists, who for several years had been analysing the relationship between the social structure and formal aspects of various artefacts produced in different cultures. However, it was Alfred Gell's theory that provided the strongest impetus for these studies and he is rightly acknowledged as the founder of the theory of the 'agency of things'.

In his 1992 essay 'The Technology of Enchantment and the Enchantment of Technology' Gell formulated the core of his methodology, though he did not employ the term 'agency' at this stage. His theory proposed viewing a work of art as an object, an item or a thing 'rather than a vehicle for extraneous social and symbolic message'. ${ }^{13}$ At the same time, Gell defined artworks 'as components of a vast and often unrecognized 
technical system, essential to the reproduction of human societies'.${ }^{14}$ He claimed that the power of art objects, which is able to cast a spell on individuals, 'stems from the technical processes they objectively embody'. ${ }^{15}$ Gell expanded that theory in his book Art and Agency: An Anthropological Theory published posthumously in 1998. ${ }^{16}$ Though to some extent controversial, this publication remains the fundamental contribution to the study of the agency of things. ${ }^{17}$ As an anthropologist, Gell perceived things, including works of art, as 'social agents', which in a historic perspective were typically relegated to the role of 'secondary agents' ${ }^{18}$ Humans, as 'primary agents', were 'endowed with the capacity to initiate actions/events through will or intention', while 'secondary agents' are 'entities not endowed with will or intention by themselves but essential to the formation, appearance, or manifestation of intentional actions. It will be apparent that "indexes" are, normally, "secondary" agents in this scene; they borrow their agency from some external source, which they mediate and transfer to the patient. ${ }^{19}$ Importantly, Gell stressed that the active power of an artwork as a 'secondary agent' can differ from the original intention of its maker or patron, and can similarly change over time. Gell introduced the term 'distributed personhood', defined as personhood extended beyond the body-boundary through various artefacts, which permits the exertion of agency within a certain milieu. ${ }^{20}$ Later in his work, when analysing the concept of style, Gell implemented a new term, namely a 'distributed object'. He suggested that the groups of artworks which become increasingly numerous in time and space, yet linked through the network of social relations (such as patronage, artistic activity, collecting and research) should be perceived as a spatio-temporal, bound together, dispersed population 'having many spatially separated parts with different micro-histories' ${ }^{21}$ This permits the anlysis of both the relationship between various objects and the elements within a particular work of art as parts of one whole. As they are grouped according to established rules, the analysis of the structure of the 'distributed object' typically reveals laws structuring a specific society. ${ }^{22}$ Gell, as an anthropologist, explored these aspects using examples from the art of the Pacific tribes. However, he supported his theory with works by the Western European artists, notably Rembrandt and Duchamp. The brief discussion of art historical issues opens up the possibilities for art historians to explore further these notions in much more depth, in order to describe the unique character of the work of art which distinguishes it from other artefacts active in the humans- non-humans collectivity.

Traditional approaches in art history highlight the significance of a specific image in the socio-historic fabric, or investigate its strictly functional aspects. The relationships among the objects are perceived as intended or imparted merely by human agents such as artists, patrons, beholders or collectors. Therefore the power of the nexus of art itself seems insufficiently acknowledged. The theory of agency can describe how a determined role and use of an object or a group of artworks created, shaped and consolidated certain models in material and ideological spheres across all levels of societies. In other words, the agency allows the analysis of mechanisms structuring the relationship between an artwork and an individual or a group, which, in turn, illuminates the nature and inner workings of various social networks. Thus agency, through focusing on the objects, enables a close investigation of individuals, groups and social structures. Artworks are active agents able to influence social networks in subjective and tangible ways, unlike sweeping historic processes which usually formed static backgrounds for discussions of the function of artefacts. The active relationships within human and non-human social networks are multidirectional and the definition 
of their nature depends on the scientific perspective. ${ }^{23}$ Moreover, agency reveals the performative character of function. It emphasises the temporality of any role played by an object and allows the exploration of moments of perseverance and shifts in any given function over time. Therefore the methodology itself has an agency, as the temporal character of an investigated, active object has the capacity to also influence the researcher and shape her/his perspective.

Alfred Gell's theory stimulated a wide response, particularly in the studies of contemporary art and in various analyses of the materiality of the work of art and the material cultural in general. Gell's approach was also broadly implemented by ethnographers in their studies of art from different cultural contexts. ${ }^{24}$ Yet recently, Liana Chua and Mark Elliott complained that until 2008 there had been no interdisciplinary reflection upon issues raised by Gell. ${ }^{25}$ Our aim is the opposite: we choose to focus on art of a particular historic period, because we believe that studies of the artistic phenomena in Western Christendom of the pre- and early-modern era allow the retention of the traditional boundaries of the discipline, and at the same time reveal the unparalleled interest in objects and their physical manipulations. This approach goes beyond the traditional studies of the function of objects by instead focusing on a vast array of activities, from religious to medicinal, in which things not only participated but which they at times enabled. This specific enquiry was facilitated by important changes which occurred from the thirteenth century in terms of iconography (devotional images, which spurred more visceral responses and encouraged physical interaction) and function (the origins of the altarpieces and reliquaries in the form of ostensories, the relation between the cult of the Eucharist or the cult of relics and the new function of the image). Medievalists are usually sensitive to the material aspects of studied objects, or, rather, concentrate less on humans than historians of art of other epochs for various reasons. First, only in the late Middle Ages and only exceptionally do they deal with famous artists such as the Limburg brothers or patrons such as Jean de Berry. Second, 'before the era of art' ${ }^{26}$ the objects were produced for various specific purposes, not merely as 'works of art'. They were a part of the lived reality and vital components, which structured human behaviours. The difference between the artistic and non-artistic object was thus much more blurred than in subsequent periods. Third, devotional and miraculous images - regarded as though they were humans - often studied, even if variously interpreted by medievalists, reveal the dialectic nature of the image as both a material object and a representation. However, it should be emphasised that in the specific studies on medieval and early-modern animated statues, the category of agency was in use in the more limited meaning of 'performance of an action' to discuss figures with moveable heads, able to blink, speak, walk, sweat or bleed. ${ }^{27}$

In the early modern world many new phenomena emerged in terms of iconography, function and technique. We observe the rise of the connoisseurship, practices of collecting and categorising of both artistic and natural things, as well as things understood as commodities, visible through their consumption. However, similarly important were those practices which remained unchallenged and unquestioned over centuries, thus blurring the boundaries between the medieval and early-modern world. To give just one example, the importance of certain active things such as animated figures, devotional images and polyptychs, which offered many different views on various occasions, continued well into the seventeenth century. Certainly, even after objects became primarily manifestations of the contemporary collecting impulse, many objects produced 


\section{Art History Empowering Things}

by craftsmen who, in the meantime, became artists, had specific functions - and they were devised to best fulfil them.

The study of art from the pre-modern period requires locating and defining the original and secondary functions of things. Furthermore, the agency of things can be discussed in relation to different scales from triptychs and polyptychs standing on altars to small diptychs for private devotion. It can reveal the active, participatory character of the majority of things. The materiality of religion during the investigated period is overwhelming in its richness; from books, reliquaries and liturgical vessels, through carved and painted chargers with the head of St John the Baptist, to skilfully carved prayer-nuts or cheap print series and individual impressions - these were all empowered things. Things were also active outside the realm of religion, most importantly in the early-modern medical practices. Accurate diagnosis and treatment was strictly based on an analysis of substances, the faith invested in medicinal properties of the specific matter and skilful employment of various tools. Furthermore, things structured the interaction between doctor and patient, and empowered the former while offering reassurance to the latter. The observation that things exercised agency in various environments will create the basis for theoretical and historic examination.

The aforementioned objects escape easy categorisation. Therefore it is challenging to analyse them using traditional art historical methods, based on the investigation of underlying principles, stylistic classifications, and attempts to rationalise them, and clarify and discuss them scientifically. The traditional art history was focused on constructing certain trends based on a definite number of fixed qualities, readily definable and comparable, pushing aside all that was more elusive and tangential. ${ }^{28}$ The scientific discourse resulted from contrasting the subjective, direct experience with understanding formulated through cognitive distance. In this narrative, artworks constituted merely visual artefacts, objects of knowledge. In this volume the authors follow a different route, closer to Heidegger's thought, which included the work of art into a realm of beings. The ongoing conversation in medieval literary and cultural studies over the past six years about object-oriented ontology, as well as its importance in contemporary art practice, encouraged scholars to view various aspects of the preand early-modern art in that specific context. ${ }^{29}$ However, the communicative power of things should also be viewed from a much more established perspective formed by medieval mysticism and idealist writings, which stressed that the 'moment of spontaneous receptivity to the call of things is the moment before self-consciousness ... the moment when the self has yet to define itself over and against objects. ${ }^{30}$ We need to establish paths of investigations which would permit us to understand how things operated in the pre- and early-modern world. Hence we require new methods of enquiry through which things could communicate to us the ways in which they structured their original cultural fabric. Contributors to this volume shed a new light on the importance of case studies, which should not be seen as means to formulating a new theory, but rather as an end in itself. The close attention to the objects and their specific contexts allows us to overcome the distance and reveals the operational systems in which the artwork as a work 'belongs uniquely within the region it itself opens up'. ${ }^{31}$

In the first part of the volume, 'Material Agency', the authors show a variety of ways, in which the notion of agency can be discussed according to the aspects of matter and techniques, which are the underpinnings of any artistic activity. The individual contributions discuss the role of the materials, not simply as vehicles for conveying immaterial ideas but as affecting senses and having their own agency within various 
socio-historic networks. In the opening essay, Andrew Morrall discusses objects made of unicorn horn, material of special agency because of its unknown provenance. $\mathrm{He}$ explores how people reacted and engaged with this unfamiliar, magical, but believable matter. They called for a strong sensorial experience engaging not only the sense of sight as beautiful objects enshrined inside Kunstkammer but also taste as people would drink from those unicorn horns safely, unthreatened by the poison. This ability of things to affect various senses is discussed further by Barbara Baert, Hannah Iterbeke and Lieve Watteeuw. The team presents a novel type of devotional object, namely Enclosed Gardens from the female convent in Mechelen. The authors describe how the mixed-media ensembles engaged different senses through the use of organic and inorganic materials. Through the sound of silk and paper when those gardens were touched and through the evocative smell of flowers those objects not only visualised the Paradise, but brought it closer to the experience of all the senses. The making of those gardens through the procedure of 'controlled randomness' and daily care for the fragile components of those objects sheds new light on female spirituality.

While all contributors to the volume interpret the term 'things' very broadly it is in the second part titled 'The Power of Things' that the clear-cut distinctions between the subject and the object are explicitly challenged. The papers follow Arjun Appadurai's ${ }^{32}-$ and more recently Tim Ingold's - concerns about the need for nuancing the notion of things, which at once can be 'generated and dissolved within the fluxes of materials across the interface between substances and the medium that surrounds them' ${ }^{33}$ and 'a way to capture the stubbornness of materiality of things, which is also connected to their profusion, their resistance to strict measures of equivalents, and to strict distinction between the maker and the made, the gift and the commodity, the work of art and the object of everyday life. ${ }^{34}$ This idea might be more obvious for archaeologists, ethnologists, anthropologians, who challenge standard assumptions of material culture studies by focusing on 'frequently overlooked moments of direct interaction between man and the material'. ${ }^{35}$ Recently, on the wave of the 'material turn' art historians also turned to works regarded as objects, as proven, for instance, by the 33rd CIHA Congress The Challenge of the Object organised in Nuremberg on 15-20 July 2012.36

The 'material turn' posed new questions for the study of images and offered a perspective in which they became intertwined in the social networks and prompted a revived discussion about the sources of their power. ${ }^{37}$ In the first essay in the part on 'Power of Things', Robert Maniura investigates the real nature of the interaction between the faithful and the miraculous images. He argues that with their mimetic qualities those paintings became valid participators and active agents that stood for the body of the saint. He relates their miraculous character to the beholder's conscious choice to act as if in the presence of a real person. The miraculous image enabled the acting out of the specific kind of devotions to various saints, while its mimetic qualities allowed it to apparently transform the devotee through miraculous healing and other bestowed graces. The section continues with Rosa Porto's study of a striking imagen de Santiago, still preserved in the royal monastery of Las Huelgas de Burgos, where it has been kept for almost seven centuries. The statue of the Apostle Saint James is empowered by the king in order to act for him during the knighting ceremony. The interaction between king and statue happens on seemingly equal terms, and the statue becomes invested with a seemingly real power to transform the king. As well as challenging the distinctions between subject and object, such use of an articulated statue problematised the perception of the event and activated various connotations 
in the beholders' minds. In the concluding essay, Peter Dent takes as his starting point the early twentieth-century poem by Rilke to explore the mechanisms of the agency of sculpture and how it can encourage the viewer to alter his or her life. The threedimensional artwork can function differently in various cultural and chronological orders, its agency is not limited to a single place or moment in time. Dent poses a question about the historic perspective on agency of artworks and whether beauty is a valid category in those enquiries. He argues that the mode of beauty in Gell's thought is static and explores the possibilities that artworks may immobilise the spectator, as opposed to stimulate action, to transform one's life. Dent calls for the reinterpretation of such works as Renaissance wooden crucifixes from Augustine's perspective as a voice, and argues for 'beauty as the rhetorical character of the work'.

Various scholars address the weak points in Gell's thought such as the lack of aesthetic consideration. ${ }^{38}$ They also point to the need to historicise agency, to trace historically the shifts in the meaning of the notion, which would allow the objects of the past to be dealt with aptly. ${ }^{39}$ Nonetheless, despite its shortcomings Gell's approach does seem to describe objects in more accurate terms than mere stylistic or iconographic considerations. Through this methodology things become powerful secondary social agents because of the intentions of the authors, patrons, recipients or owners.

Therefore the following part on 'Objects as Social Agents' considers things as active participants in various social networks. Leah Clark describes how material preciousness conditions the agency of the object. She discusses wide-ranging artefacts, from reliquaries to jewels, to assess how their materiality responded to the human desire to leave evidence of the temporary ownership on its surface. She also engages with Renaissance inventories from Modena, which she interprets as 'social agents', because they too became indicators of poor or good relations through the fates of the objects they documented. Through discussing various social actions in which those objects were engaged - from displaying and cherishing, to pawning and stealing - Clark argues that objects, especially precious objects, tested human behaviour. From Clark's luxury things, Jaya Remond brings us back to arguably the most active agent of the earlymodern world, namely the print. In her contribution, she explores the various roles Dürer's woodcuts and engravings played during the artist's trip to the Netherlands. Portable and reasonably cheap prints served Dürer as tangible tokens of his gratitude, or as gifts or in exchange for other objects. Remond breaks down the 110 transactions described in Dürer's diary to categorise them as exchanges, sales and gifts. She nuances the nature of Dürer's gesture and argues that he consciously exploited the capacity of prints to become a vehicle conveying his individuality as a giver and maker. In the final contribution to the part, Alexander Lee examines the agency of three drawings sent by Michelangelo to Tommaso de' Cavalieri to address the importance of gift-giving as a mode of solidifying social relationships. Lee also seeks to locate those celebrated works in the gendered world of the Renaissance 'economy of gifts', to create a strictly masculine counterpart for a different, already well-studied relationship, forged by drawings between Michelangelo and Vittoria Colonna.

However, things not only participate in social relationships but, through time, they also forge close and intimate bonds with individual users. In particular, various physical manipulations allow links to be established which are not merely conceptual, but much more tangible. Therefore, thinking about the character of those relationships should be rooted in phenomenology. In art historical investigations 
this perspective allows to complement the traditional visual studies with analysis of tangible interactions between humans and things. It permits the description of the familiar, everyday experience of eliminating the boundaries between the subject and the object, and the creation of hybrid entities. In turn such a description of relationships requires attention to their changing dynamics in a historic perspective. Thus the agency of things, or interaction between human and non-human agents, are described as a performative act. It challenges, accepted since Lessing, the division of arts into the temporal and spatial. Finally, it allows the individual contact with the object to be traced and how it influences tradition and social practices. ${ }^{40}$

The fourth part deals with the important question of the 'Agency of Physical Manipulations'. Jack Hartnell takes up the problematic artefacts, surgical saws, to assess how these objects could have operated between the realms of beauty and utility. This case study reveals the importance of surviving objects as the only true witnesses to practices of the past. Saws do not simply record the surgical procedure, they are not merely complementary to written and visual sources illustrating the act. They had the capacity to direct their own use during the surgery. Hartnell argues that the elaborate forms of those objects, as uncomfortable as they were for those who handled them, were permanent reminders of their primary role as hand-held medical tools. Following the discussion of the agency of things in earlymodern medical practices, Karen Overbey and Jennifer Borland discuss physicians' folding almanacs to assert their capacity as 'a space of knowledge'. The authors through their own physical assessment reveal the crucial role of the manuscripts in structuring the interaction between the patient and the doctor. Those almanacs were portable and encouraged their manipulation in various ways, through holding, unfolding, turning and opening. Overbey and Borland discuss the specific aspects of those almanacs, such as the format and the binding, to explore where the agency of the objects resided. They suggest that in some cases simply manipulating the folded pages triggered the physician's stored memory, as well as allowed the illiterate patient to recognise various important illuminations placed strategically in the manuscript. The materiality of the text and the physical properties of manuscripts is discussed further in the final contribution to this part by Wim François. He addresses Luther's interest in the different layout of editions of the Bible printed between 1538 and 1542. François deals with the significance of the non-confessional character of the majority of biblical illustrations in those editions. $\mathrm{He}$ also points to the various modes of appropriation of a Bible through certain operations divided into three categories, namely that of users' traces, owners' marks and content-related interventions, such as marginal notes and censorship measures. Importantly, he points to the challenges in assessing the agency of Bibles at different social levels, as books owned by the poorer members of the society would have been used until they had to be thrown away.

As a way of opening our volume to subsequent discussions, we conclude with Jacqueline Jung's wide-ranging exploration of various props used by St Hedwig to materialise her devotion. Hedwig's life reveals different strategies from selfmortification, which helped the thirteenth-century saint to change her body into an image and to become more like the Crucified Christ to boots which she wore around the neck to manifest her humility. The analysis of those aspects shows how materials can make people remember those absent bodies or absent practices in the most instantaneous way. Objects enabled 'imaginative projections' and seeing 
things unseen. The pattern of St Hedwig's life is based on series of interactions with the material world such as stalls once occupied by nuns from her convent or towels she kissed like relics. Jung explores the limitations of the notion of the agency of things through suggesting ways in which things remain indexes highlighting the absence of the human, charismatic agent.

We hope that the volume will become a fresh voice in the discussion on the validity of the notion of agency in studies on medieval and early-modern art. Despite its various limitations, Gell's theory allows art historical studies of well-known objects to be included as well as those which hitherto had remained inaccessible because of the lack of a methodology which permitted such investigations. However, it must be emphasised that Gell presents the active role of artworks in developing social and interpersonal relations through the 'abduction' of their agency. The research presented in this volume focuses on the works of art and their materiality, accessible also through the analysis of the physicality of their makers and intended users. Thus, following Latour, they assert that social aspects cannot be divorced from the material.

\section{Notes}

1 James Elkins, The Object Stares Back (New York: Simon \& Schuster, 1996), 40.

2 Ann-Sophie Lehmann, 'Wedging, Throwing, Dipping and Dragging: How Motions, Tools and Materials Make Art', in Barbara Baert and Trees de Mits (eds), Folded Stones (Ghent: Institute for Practice-based Research in the Arts, 2009), 41-60; Michael Cole, 'The Cult of Materials', in Sébastien Clerbois and Martina Droth (eds), Revival and Invention: Sculpture Through Its Material Histories (Oxford and Bern: Peter Lang, 2011), 1-15; Christy Anderson, Anne Dunlop and Pamela H. Smith (eds), The Matter of Art. Materials, Practices, Cultural Logics c.1250-1750 (Manchester: Manchester University Press, 2015).

3 The Biography of the Object in Late Medieval and Renaissance Italy, ed. by Roberta J. M. Olson, Patricia L. Reilly and Rupert Shepherd (Oxford: Blackwell, 2006); Peta Motture and Michelle O’Malley (eds) Re-thinking Renaissance Objects: Design, Function, and Meaning (Oxford: Wiley-Blackwell, 2011).

4 Marta Ajmar-Wollheim and Flora Dennis (eds) At Home in Renaissance Italy (London: Victoria and Albert Museum, 2006); Victoria Avery, Melissa Calaresu and Mary Laven (eds) Treasured Possessions: From the Renaissance to the Enlightenment (London: Philip Wilson, 2015).

5 Mary Douglas and Barry Isherwood, The World of Goods: Towards an Anthropology of Consumption (Harmondsworth: Penguin, 1978).

6 Andrew Gardner, 'Agency', in R. A. Bentley et al. (eds), Handbook of Archeological Theories (Lanham, MD: AltaMira Press, 2009), 99.

7 Karen Barad, 'Posthumanist Performativity: Toward an Understanding of How Matter Comes to Matter', Signs 28 (3), Gender and Science: New Issues (Spring 2003), 801-31.

8 Bruno Latour, Reassembling the Social: An Introduction to Actor-Network Theory (Oxford: Oxford University Press, 2005); Krzysztof Abriszewski, Poznanie, zbiorowość, polityka. Analiza teorii aktora-sieci Bruno Latoura (Cracow: Universitas, 2008).

9 Michel Callon, 'Techno-economic Networks and Irreversibility', in John Law (ed.), A Sociology of Monsters: Essays on Power, Technology and Domination (London and New York: Routledge, 1991), 140.

10 Bruno Latour, Pandoras Hope. Essays on the Reality of Science Studies (Cambridge, MA and London: Harvard University Press: 1999), 122; Latour, Reassembling the Social, 44.

11 Chris Gosden, 'What Do Objects Want?', Journal of Archeological Method and Theory 12 (3) (2005), 193-211.

12 Bjørnar Olsen, In Defense of Things: Archaeology and the Ontology of Objects (Lanham, MD: AltaMira Press, 2010), 124.

13 Alfred Gell, 'The Technology of Enchantment and the Enchantment of Technology', in Jeremy Coote and Anthony Shelton (eds), Anthropology, Art and Aesthetics (Oxford: Clarendon Press, 1992), 43. 
14 Ibid., 163.

15 Ibid.

16 Nicholas Thomas, 'Foreword', in Art and Agency. An Anthropological Theory (Oxford: Clarendon Press, 2013), vii.

17 Robert Layton, 'Art and Agency: A Reassessment', Journal of the Royal Anthropological Institute 9 (3) (Sep., 2003), 447-64; Robin Osborne and Jeremy Tanner, 'Introduction: Art and Agency and Art History', in Robin Osborne and Jeremy Tanner (eds), Art's Agency and Art History (Oxford: Wiley-Blackwell, 2007), 1-27.

18 Alfred Gell, Art and Agency. An Anthropological Theory (Oxford: Clarendon Press, 2013), 17-19.

19 Ibid., 36.

20 Ibid., 104.

21 Ibid., 220.

22 Ibid., 215-19.

23 Ibid., 57.

24 Christopher Pinney and Nicholas Thomas (eds), Beyond Aesthetics: Art and the Technologies of Enchantment (Oxford: Berg, 2001); Osborne and Tanner, Art's Agency and Art History; Daniel Miller (ed.) Materiality (Durham, NC: Duke University Press: 2005); Ian Hodder, Entangled: An Archaeology of the Relationships between Humans and Things (Malden, MA: Wiley-Blackwell, 2012); Liana Chua and Mark Elliott (eds), Distributed Objects. Meaning and Mattering after Alfred Gell (New York: Berghahn, 2013); Petra Lange-Berndt (ed.) Materiality (London: Whitechapel Gallery; Cambridge, MA: MIT Press, 2015).

25 Chua and Elliott, Distributed Objects, 3.

26 Cf. Hans Belting, Likeness and Presence. A History of the Image before the Era of Art (Chicago: Chicago University Press, 1997).

27 Jan N. Bremmer, 'The Agency of Greek and Roman Statues', Opuscula. Annual of the Swedish Institutes at Athens and Rome 6 (2013), 7. See also Johannes Tripps, Das handelnde Bildwerk in der Gotik. Foschungen zu den Bedeutungsgeschichten und der Funktion des Kirchengebäudes und seiner Ausstattung in der Hoch- und Spätgotik, 2nd revised and enlarged edn (Berlin: Gebrüder Mann, 2000) and Kamil Kopania, Animated Sculptures of the Crucified Christ in the Religious Culture of the Latin Middle Ages (Warsaw: Neriton, 2010).

28 Cf. Michel de Certeau, The Practice of Everyday Life, trans. Steven Rendall (Berkeley, CA: University of California Press, 1984), 94-6.

29 Jane Bennett, Vibrant Matter: A Political Ecology of Things (Durham, NC: Duke University Press, 2010); Ian Bogost, Alien Phenomenology: Or, What It's Like to Be a Thing (Minneapolis, MN: University of Minnesota Press, 2012); Jeffrey Jerome Cohen (ed.) Animal, Vegetable, Mineral: Ethics and Objects (Washington, DC: Oliphaunt Books/Punctum Books, 2012).

30 Andrew Cole, 'The Call of Things: A Critique of Object-Oriented Ontologies', Minnesota Review 80 (2013), 110.

31 Martin Heidegger, 'The Origin of the Work of Art', in his Off the Beaten Track, ed. and trans. by Julian Young and Kenneth Haynes (Cambridge: Cambridge University Press, 2002), 20.

32 Arjun Appadurai, The Social Life of Things. Commodities in Cultural Perspective (Cambridge: Cambridge University Press, 1986).

33 Tim Ingold, 'Materials Against Materiality', Archaeological Dialogues 14 (1) (2007), 1.

34 Arjun Appadurai, 'The Thing Itself', Public Culture 18 (1) (2006), 21.

35 Hans P. Hahn, 'Words and Things: Reflections on People's Interaction with the Material World, in Joseph Maran and Philipp W. Stockhammer Materiality and Social Practice. Transformative Capacities of Intercultural Encounters (Oxford: Oxbow Books, 2012), 12; Cf. Janet Hoskins, Biographical Objects. How Things Tell the Stories of People's Lives (London and New York: Routledge, 1998); Bjørnar Olsen, 'Material Culture After Text: Remembering Things', Norwegian Archeological Review 36 (2003), 87-104; Bjørnar Olsen, In Defense of Things: Archaeology and the Ontology of Objects (Lanham, MD: AltaMira Press, 2010); Bjørnar Olsen et al., Archeology: The Discipline of Things (Berkeley, CA: University of California Press, 2012); recently critically summarised by Nanouschka M. Burström, who offered a more in-depth theoretical analysis on biographies of objects. See her: 'Things in the Eye of the Beholder: A Humanistic Perspective on Archaeological Object Biographies', Norwegian Archaeological Review 47 (2014), 65-82. 


\section{Art History Empowering Things}

36 Georg Ulrich Großmann and Petra Krutisch (eds) The Challenge of the Object/Die Herausforderung des Objekts, 33rd CIHA Congress (Nuremberg: Verlag des Germanischen Nationalmuseums, 2013).

37 Cf. David Freedberg, The Power of Images. Studies in the History and Theory of Response (Chicago: University of Chicago Press, 1989).

38 Ross Bowden, 'A Critique of Alfred Gell on Art and Agency', Oceania 74 (2004), 320-3.

39 Caroline van Eck, 'Living Statues', Art History 33 (4) (2010), 648.

40 Cf. Michael Brian Schiffer and Andrea R. Miller, The Material Life of Human Beings: Artifacts, Behavior and Communication (New York: Routledge, 1999). 
Part 1

Material Agency 



\title{
1 The Power of Nature and the Agency of Art The Unicorn Cup of Jan Vermeyen
}

\author{
Andrew Morrall
}

Recent scholarship has revealed the sixteenth-century Kunst-und-Wunderkammer to be a world pulsating with objects, natural and manmade, whose exotic materials and strangeness of forms on the one hand, and technical virtuosities and inventiveness of design on the other, collectively proposed mute lessons and encouraged active reflections in fields well beyond the aesthetic, including the various branches of natural philosophy, geography, ethnography, history, and ethics. Behind the fascination with natural materials, especially the newly discovered fauna of exotic lands and their byproducts - shells, horns, bezoar stones, feathers - or with rare gemstones and metals lay a belief in matter as an active, living agent in the world, possessed of intrinsic powers and virtues. The following article investigates a category of artwork that was fashioned from such exotic natural materials, made primarily for the Kunstkammer. The focus will be upon the unicorn horn, a material regarded by contemporaries as the most precious of all such natural objects and deemed so rare and so powerful as to be able to significantly affect its ambient environment. More than any other animal, largely because of its obscure origins and the consequent mystique, prestige and enormous financial worth of its only concretely known part, the horn, the unicorn was the object of intense scrutiny and study. Numerous dedicated published accounts drew upon a range of ancient and medieval literature and a wealth of shared humanist speculation and debate on the subject. Andrea Bacci, a Florentine physician and man of letters, who wrote such a treatise in 1573 for Francesco, the Grand Duke of Tuscany, was not exaggerating when he called the unicorn the 'epitome of Nature's secrets' and claimed that no previous age had displayed such a fascination with this rare animal as did his own epoch. ${ }^{1}$ The following article seeks to explain the sources of the unicorn horn's power as it was understood at a particular historical moment and under particular cultural conditions - between about 1550 and 1650 - and how that power was consciously harnessed and manipulated by the craftsmen who fashioned them: the 'power of nature and the agency of art' of the title. ${ }^{2}$ Finally, it will suggest how habits of study, encouraged and in a sense structured by the categories of collecting fostered by the Kunstkammer - epitomized in Bacci's search for 'Nature's secrets' quoted above - led to the gradual dismantling of the centuries-old body of knowledge that surrounded this fabled creature. ${ }^{3}$

The particular object of scrutiny in this article is a goblet made from unicorn horn, today in the Kunsthistorisches Museum (Figure 1.1). ${ }^{4}$ Rudolf Distelberger convincingly attributed the cup to Jan Vermeyen (before 1559-1608), the most important and gifted goldsmith to work for Rudolf II. Born in Brussels and trained in Antwerp, the son of the painter Jan Cornelisz Vermeyen, he was in Frankfurt in 1589 where already 


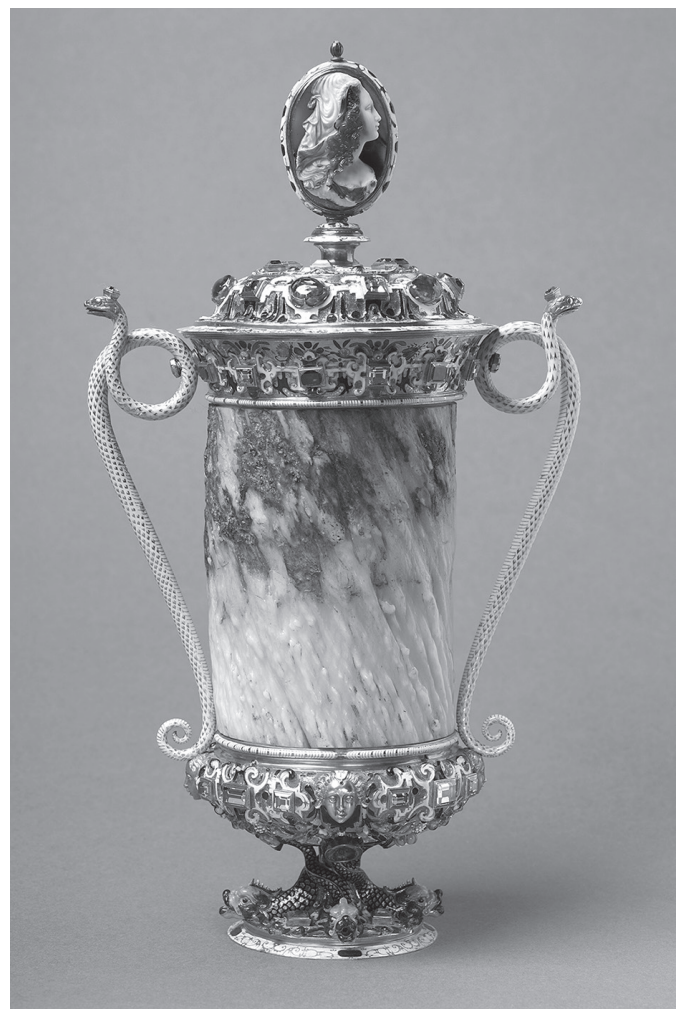

Figure 1.1 Jan Vermeyen and Ottavio Miseroni, Unicorn Horn Cup, narwhal horn, diamonds, rubies, gold and enamel work. Vienna, Kunsthistorisches Museum, Kunstkammer, inv. no. KK 1113.

by 1596 he was in contact with the Emperor. On 1 October 1597 he was taken on as Kammergoldschmied with a monthly salary of 10 gulden. The high worth Rudolf accorded him is shown by the fact that Rudolf gave him an additional 100 gulden per year by November and in 1602 doubled his salary again. Though none of his surviving works are signed, the key work through which his style is known is the imperial crown of Rudolf II, completed in 1602. On the basis of comparison with the crown, Distelberger dated the cup to between 1600 and $1605 .{ }^{5}$

The unicorn horn is set in a mount made up of a variety of extremely expensive materials: refined gold and enamel work set with rubies and diamonds and surmounted by a double cameo carved in agate. This latter is attributed to the lapidary artist, Ottavio Miseroni (1567-1624), another highly esteemed craftsman of Rudolf's court, with whom Vermeyen collaborated on a number of works. ${ }^{6}$

From at least 1619 , the date of the earliest surviving documentary reference, the unicorn cup was kept within the imperial treasury. ${ }^{7}$ This was an especial repository of the Kunstkammer that housed the most costly of Emperor Rudolf's possessions, including the imperial insignia: the crown, the orb, the apple and scepter, all of which 
share a certain stylistic affinity with the unicorn goblet. A 1605 report of the collection by the Duke of Savoy's ambassador, Carlo Francesco Manfredi, recorded these imperial objects and marked out as the two most valuable and inalienable possessions of the entire Habsburg collection a large bowl, carved from agate, believed to have belonged to the Emperor Constantine, whose natural veining spelt out the word 'Xristo' in nature's hand, and an extraordinary unicorn horn, six feet in length, exhibited on a simple mount but otherwise unadorned. ${ }^{8}$ As is clear from Manfredi's awed report, possession of such extraordinarily rare natural creations, in which God's hand was palpable, was an important source of political agency. For the Habsburg emperors, the ownership and guardianship of these precious rarities reinforced their claim to worldly imperium as a divinely ordained right.

The source of the unicorn horn's quasi-divine aura lay in a tradition going back at least to the Greek Physiologus, compiled between the second and fifth centuries CE, and known continuously throughout the medieval and Renaissance period. ${ }^{9}$ This text was the first to invest the unicorn with Christological associations and was the source of various stories associated with the unicorn later taken up in medieval literature and art: the creature's virtues of strength and gentleness, which were explicitly equated with Christ; the belief that the unicorn could be tamed only by sitting in the lap of a virgin; as well as the Hunt for this rare and beautiful beast, which came to symbolize Christ's passion. Such associations endowed the unicorn horn with both a noble and a sacred character, its numinous qualities appropriate for the insignia of office, such as the staff of bishops or the scepters of emperors. ${ }^{10}$ This long-standing and allpervasive symbolic understanding arose in part from the Physiologus's account of the following myth:

In the places where [the unicorn] dwells there is a great lake, and to this lake all beasts resort to drink. But before they assemble themselves, there comes the snake, and casts her poison on the water. And the beasts when they observe the poison dare not drink, but stand aside and wait for the Unicorn. He arrives and goes straight into the lake, and marks the sign of the Cross with his horn; and thereupon the poison becomes harmless, and all those beasts drink. ${ }^{11}$

In the light of this myth, the unicorn, supreme among animals, stood symbolically as an exemplar of the qualities of responsible rulership and its horn, therefore, as an appropriate possession of princes. Management of such rare specimens thus assumed important social and political overtones. Such wonders contained in the Prague Kunstkammer of the Emperor Rudolf II were displayed only very sparingly to highranking visitors such as Manfredi, for the wondrous was intertwined with secrecy, and secrecy was the province of princes.

Besides the horn itself, the other constituent parts of Vermeyen's unicorn cup also spoke to kingly virtues. The diamonds and rubies imparted by their own rarity, quality and sheer monetary value a dignity that matched the uniqueness of the unicorn they adorned. In the 1617 inventory, the cup was valued at 4,500 gulden. Collectively, the value of the gold enamel work and precious stones was established as 2,809 gulden, making the horn the most expensive element at 1,691 gulden. ${ }^{12}$

The importance Rudolf accorded the choice of jewels for such works and the degree of thought that went into their design can be seen in the parallel efforts he took to 
acquire the stones for Vermeyen's imperial crown. In 1601, under a seal of secrecy, he undertook a search across Europe for suitable diamonds. The imperial Ambassador Johann van Khevenhueller in Spain had lead casts of rough diamonds made and sent with their weight and price back to Prague. The largest stone that appears in the correspondence stood at 186 carats. The prices went into the tens of thousands of ducats. In the same year Rudolf sent the gem polisher and jeweler David von Brussel to Rome where he bought a large diamond from the Jesuits for 30,000 ducats. ${ }^{13}$

In addition to their monetary worth, these gemstones possessed intrinsic virtues which could endow their owners with, or strengthen, particular attributes of character. Such beliefs were handed down within the lapidary tradition inherited from the Middle Ages. ${ }^{14}$ Standing at the apex of a well-established hierarchy of stones, the diamond, which derived its name from the Greek adamas ('unvanquished'), possessed above all the quality of insuperable hardness. It was considered the jewel of rulers and was thought to endow the wearer with superior strength, fortitude and courage. ${ }^{15}$ The ruby, too, possessed royal virtues. It was specifically coupled with the unicorn horn in medieval German literature. In the twelfth-century Alexanderlied by Lamprecht 'der Pfaffe', for example, Queen Candace presents Alexander with a unicorn valued not so much for itself as for the precious stone growing at the base of its horn:

I had from the this rich queen

A beast of proud and noble mien

That bears in his brow the ruby-stone. ${ }^{16}$

Renaissance lapidary writers ascribed similar virtues to the agate, of which the cameos of the cup's finial are made, specifically strength and prudence. ${ }^{17}$ The cameos are elaborately carved on one side with two helmeted heads, one male, one female, superimposed in classical profile (Figure 1.2(a)); the other is a profile bust of a tumbling-haired, loosely clothed female (Figure 1.2(b)). If, as seems most likely, the two superimposed profile helmeted heads represent Mars and Minerva, then the inherent virtues of the stone - of Strength and of Prudence - are symbolized in the imagery of the gods. ${ }^{18}$ Such an association between intrinsic virtue and image is made explicit in an inscription on an agate relief commesso of Minerva, attributed to the Ottavio Miseroni workshop and with mounts by Vermeyen (Figure 1.3):

\section{Cur Palladi Armorum Refertur Gloria \\ Docta Decens Bellum Regitur Prudentia}

Why is the glory of Pallas Athene's arms so well known?

[Because] War, when well conducted, is guided by Wise Prudence. ${ }^{19}$

In the unicorn cup's cameo, the intrinsic and invisible virtues inhering in the matter of the stone are similarly hypostasized - and thereby enhanced - in the image of the gods. The contemporary belief in the ability of an image carved into the stone to release its latent powers was alluded to by Rudolf II's personal physician, the doctor and natural philosopher Anselmus de Boodt in his influential Gemmarum et lapidum historia of 1609. In his discussion of the diamond, he suggested in a parenthetical aside that rather than carve a figure of Mars or of Hercules overcoming the Hydra into the stone in order to effect an augury of victory, it would be better to carve a scene of Christ's Passion, the better to lure out the good spirits within. ${ }^{20}$ 


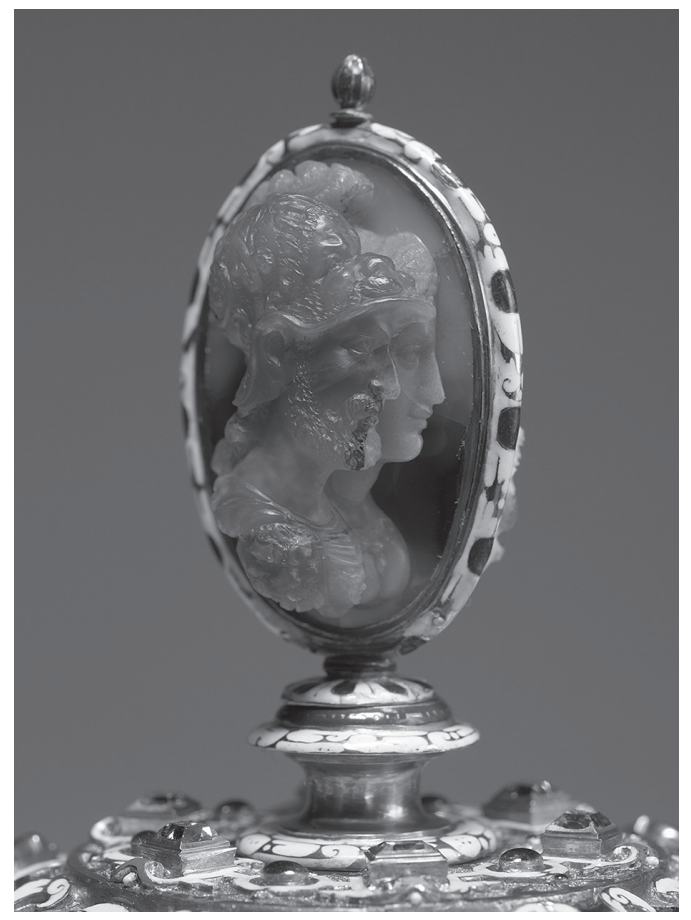

Figure 1.2(a) Detail of Figure 1.1.

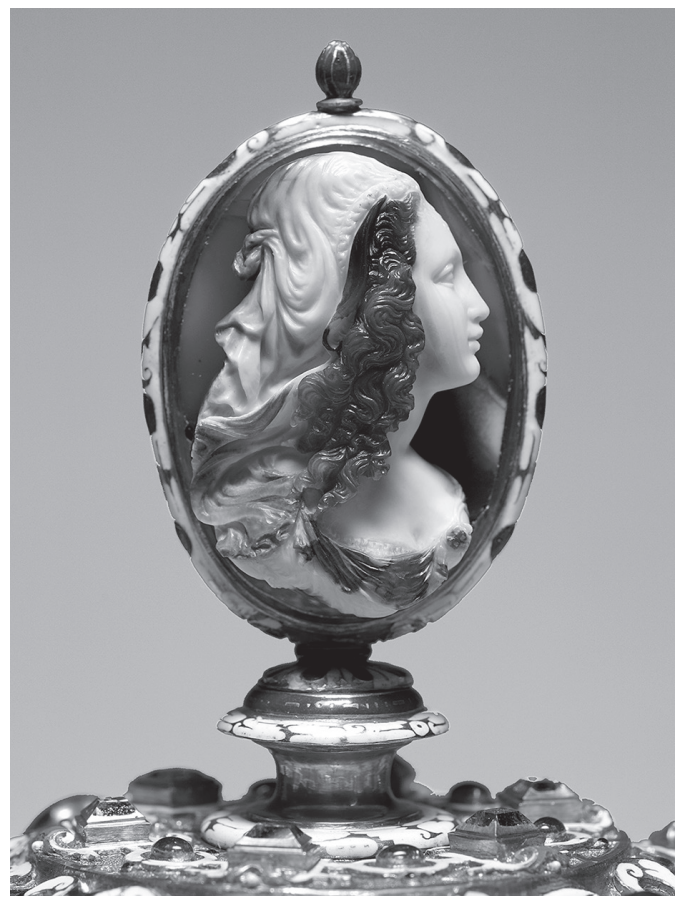

Figure 1.2(b) Detail of Figure 1.1. 


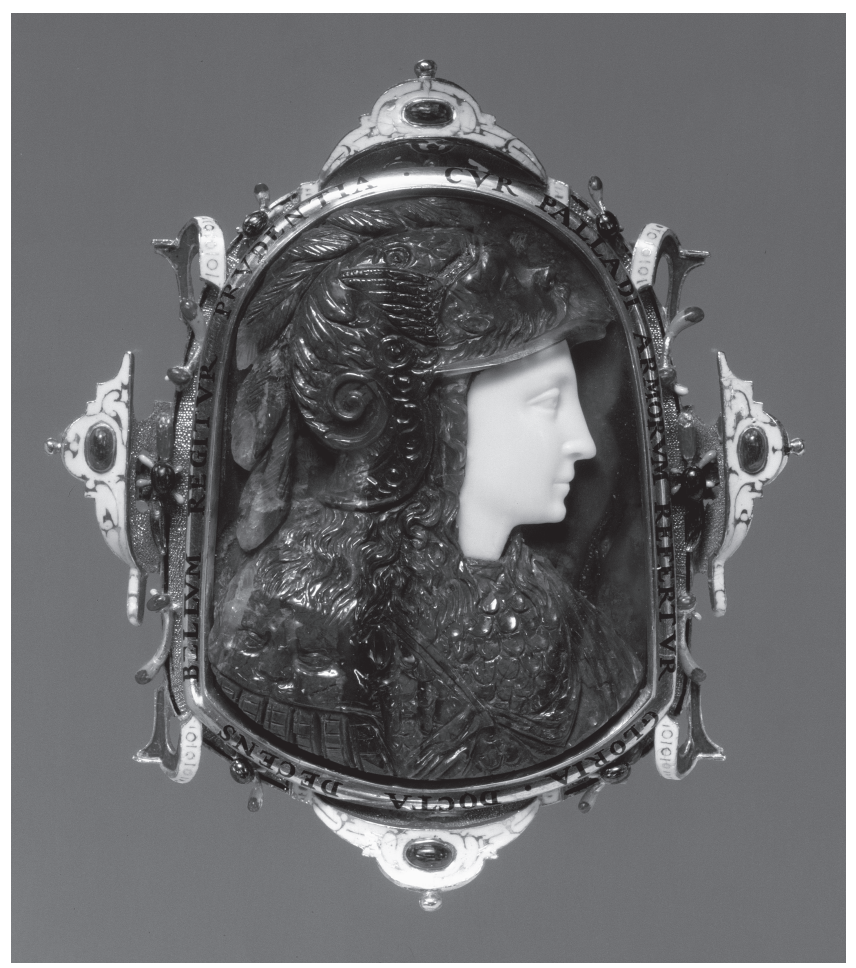

Figure 1.3 Workshop of Ottavio Miseroni, Minerva [commesso: Giovanni Ambrogio(?), mount: Jan Vermeyen], agate, jasper, silver gilt, rubies, white enamel. Vienna, Kunsthistorisches Museum, Kunstkammer, inv. no. ANSA XII 819.

To grasp a contemporary understanding of these precious materials therefore is to take into account how these multiple and interlocking levels of meaning were superimposed upon the raw experience of viewing. One would have progressed from an appreciation of the luster of these rare and costly physical materials, to a consideration of their invisible, intrinsic virtues, to a metaphysical grasp of what was in effect a summa of the virtues of Kingship.

From the lapidary tradition, Renaissance patrons inherited the attitudes towards jewels of medieval theologians, for whom the contents of their church treasuries had for long served as objects of meditation. ${ }^{21}$ Abbot Suger in the twelfth century famously wrote of his own use of the treasury of St Denis for purposes of meditation, as when beholding on the altar the jeweled cross of St Eloi:

Thus when - out of my delight in the beauty of the house of God - the loveliness of the many coloured gems has called me away from external cares, and worthy meditation has induced me to reflect on the diversity of their sacred virtues, transferring that which is material to that which is immaterial; then it seems to me that I see myself dwelling, as it were, in some strange region of the universe which neither exists entirely in the slime of the earth nor entirely in the purity of heaven; and that, by the grace of God, I can be transported from this inferior to that higher world in an anagogical manner. ${ }^{22}$ 
Four hundred and fifty years later, Anselmus de Boodt echoed these sentiments in the prefatory dedication to Rudolf II of his treatise on gems. Acknowledging the necessity for kings and emperors to adorn themselves with the borrowed lustre of precious gems, he nonetheless emphasized the fact that Rudolf's interest in gems was

in order that in them, [he] might contemplate the excellence of God and His indescribable power, which seems to have forced the beauty of the whole world into so small a body, and seems to have included in it the power of other things, and had forevermore a certain light and appearance of divinity before the eyes. ${ }^{23}$

Despite this acknowledgement of the divine origins of creation, de Boodt's treatise on gems, which ran into several editions in the course of the seventeenth century, was written in a spirit of natural philosophy. It constituted a complete reclassification of stones, with sections on their origins, properties and virtues, and powers. While it refuted many of the superstitious and magical properties stones were traditionally accorded, as R. J. W. Evans put it, '[t]he extent of its credulity and belief in the unforeseen forces which inhere in natural objects reflects the attitude towards minerals of Rudolf's whole court. ${ }^{24}$ The treatise therefore provides important evidence as to how the materials of the unicorn horn cup and its precious stones would have been regarded in the circles of the Emperor.

De Boodt included a lengthy discussion of the properties of the unicorn horn in his treatise, emphasizing its chief intrinsic virtue: that the unicorn's horn 'is so highly valued among connoisseurs of gemstones and princes, because nothing surpasses it in its ability to recognize, prevent and conquer every poison, so that it is worth more than the price of gold. ${ }^{25}$ De Boodt quoted the ancient authority of Aelian, a Roman author of about $200 \mathrm{CE}$ - as well as Pliny - by distinguishing five types of mono-horned beast: the one-horned ox, the rhinoceros, the real unicorn (monoceros), the one-horned Indian ass and the one-horned oryx, a kind of wild goat. De Boodt matched his knowledge of classical and ancient sources with his own experience: he claimed to have seen more than twenty different types of 'unicorn' horn in the collections of princes and dukes, many of them turning out to be only stag's horn or walrus teeth (Dens Rosmari). ${ }^{26}$

The markings of the horn of the authentic unicorn, which alone possessed the wondrous healing qualities, are, he said - again citing Aelian - dark reddish purple at the top, black in the middle, and white beneath. In the light of this, the dark to white coloration of the Vienna cup may have been valued as especially authentic and rare. Aelian based his own account in part upon the Greek physician Ctesias's Indika, written in the first half of the fourth century BCE, who was the first to mention the use of goblets made of unicorn horn. He wrote that in India such goblets were believed to give the drink contained in them curative or preventative properties against cramps, epilepsy or poisoning. Aelian added that only Indian noblemen could afford to own such precious goblets, which they made still more costly by elaborate mountings of gold. ${ }^{27}$ In reading de Boodt's text, it becomes clear that Vermeyen's goblet, similarly decorated, was a direct descendant of this long textual tradition.

De Boodt's accounts of the occult virtues of the ruby, diamond and agate also placed particular emphasis on these stones' faculties of detecting and protecting from poison. ${ }^{28}$ Of the ruby, he noted in particular its propensity to darken in the presence of poison; ${ }^{29}$ the hardness of the diamond, he says, 'prevails also over poisons and renders 
them powerless'; ${ }^{30}$ while the agate is especially effective against the poisons of snakes and scorpions. ${ }^{31}$

De Boodt's belief in the medical application of precious stones belongs to a wider medical seventeenth-century acceptance of amuletic therapies. For him, the virtues inherent in a stone were wholly dependent on its material substance, gathered during the circumstances of its generation within the earth - and therefore in accord with the laws of nature. He could thus debunk a popular belief in the diamond's ability to indicate whether or not a wife is faithful precisely because it was based on a misunderstanding of the diamond's nature: 'Nature does not know adultery: because marriage and the mutual pacts between spouses do not depend upon Nature but on the Law and the will of men who wish that adultery be a vice and a sin; the diamond, which is deprived of sense, cannot know that Law and will. ${ }^{32}$ Nonetheless - and this is revealing of a premodern understanding, grappling with a Nature subject to its own laws yet which is also God's creation - he does not entirely reject the claims that some diamonds have performed such feats, but rather ascribes this effect to a spirit attached to the diamond by the will of God. This spirit is not contrary to nature, but rather in accord with it (he maintains that the natural beauty of the diamond attracts good spirits), inasmuch as the fundamental cause of the universe as a whole is God, 'the great Creator of all things. ${ }^{33}$

One further element in the goblet's ornament - the serpent handles - may also allude to its alexipharmic powers (Figure 1.1). On the one hand, the serpents symbolize the inimical forces against which the unicorn horn would provide protection. From the Physiologus onwards, serpent and unicorn were considered natural enemies. Yet each snake bears a small diamond upon its head, suggesting that they are not ordinary snakes. They refer, rather, to an ancient Indian tradition of legendary dragon-snakes, which were believed to have a magical stone embedded in their foreheads. ${ }^{34}$ Shepard traced the transmission of this belief into Europe in late antiquity and thence to the Renaissance. He cites Flavius Philostratus (c.170-245 CE) who, in his life of Apollonius, related how this jewel was said to contain 'a thin crescent-like fibre, which oscillates unceasingly in the centre.' 35 By the fifteenth century, Jordanus Catalanus, Bishop of Quilon (Kollam), reported in his Mirabilia Descripta (c.1330) that in the 'Third India' there were many dragons with brilliant stones called carbuncles in their heads, besides a great quantity of serpents similarly adorned, and in Rome, Cardinal Ponzetto wrote in his Libellus de Veneis (1521) that golden fibres contained within these stones darkened when poison was brought near. ${ }^{36}$ In apparently referencing this tradition, the serpent handles on Rudolf's cup thus provided both an additional allusion to the horn's exotic, eastern origins and a possible additional source of therapeutic power.

According to the chemical understanding of the times, the horn's singular powers caused it to sweat in the presence of poison. The eminent French pharmacist, Laurens Catelan, echoed a long tradition among naturalists when he wrote in his Histoire de la nature, chasse, propriété et usages de la lycorne (1624), 'that poisonous plants and animals, when brought near it, burst and die; and the horn sweats in the presence of poison.' ${ }^{37}$ How did contemporaries explain this prodigious power in terms of natural philosophy?

The natural principles that caused the horn to sweat belonged to a system of correspondences, of 'sympathies' and 'antipathies,' among natural materials. The horn acted as a kind of 'magnetic' barrier, attracting to itself and neutralizing the noxious effusions of the poison, thereby causing a natural condensation as a by-product of this elemental battle. 
Medical opinion could be divided as to the nature of these substances and the manner in which they interacted. Seventeenth-century medical literature discloses sharp disagreements about the whys and whens amuletic materials were effective in preventing disease, arising from conflicting philosophies of the natural action of medicines upon the body. Anselmus de Boodt, for instance, as a steadfast Aristotelian, understood natural sympathies and antipathies in terms of a theory of the humors, by which dry and cold or warm and wet elements attracted each other and repelled their opposites. He vehemently disagreed with the ideas of Paracelsus (Theophrastus Bombastus von Hohenheim, d.1541), the unorthodox Swiss physician, who rejected humoral theory as the basis of matter in favor of one based on the chemical interaction of three elemental substances: salt, mercury and sulfur. At Rudolf's court, the Paraselsian camp was represented by prominent physicians and alchemists such as Michael Maier, Heinrich Kuhnrath, and Robert Fludd. Another key figure was the Swiss medical reformer, Dr Oswald Croll, whose work, the Basilica Chymica of 1609, included an exposition of Paracelsus's plague theory. This treated disease and poisons as something akin to microscopic seeds, which could be diverted from entering the body and neutralized by their magnetic attraction to certain amuletic materials. The recipe he formulated against plague, which he presented to Rudolf II, was based upon Paracelsus's famous zenexton antidote. ${ }^{38}$ It is useful for the present purpose because it clearly articulated the principles of natural sympathy by which - at least for these physicians - the innate properties of natural materials worked upon each other. Croll's antidote was a compound of dessicated and pulverized toads, the menstrual blood of young girls, white arsenic, orpiment, dittany roots, pearls, corals and oriental emeralds. His concoction formed a paste, which the physician formed into small cakes. Croll insisted that the ingredients of the zenexton be aligned with one of the planets: each toad, for instance, was to be suspended alive facing the east before it was pulverized. Croll's further addition of sapphire and hyacinth was also consciously intended to align celestial influences with mineral ingredients that had known correspondences with parts of the human body. The recipe also required making a small cylindrical metal case engraved on top with a serpent and on its bottom a scorpion. The physician imprinted the toad cakes with the seals of the serpent and the scorpion and then enclosed them in the cylinder. The chief ingredient, the pulverised toad, was chosen because that animal's tuberous and swollen skin corresponded, by the theory of signatures, to the lesions, spots, and carbuncles on the skin of plague victims. It was also believed that the toad harbored an innate hatred for and fear of man. This hatred this powerful spirit, contained in the zenexton - was thought to imprint itself on the archeus (or organizing principle) of the disease thereby destroy it. These principles - of astral alignment, of occult sympathies between things, a doctrine of signatures, and the efficacy of an impressed or carved image - were essentially those that structured the design of the unicorn goblet. For physicians like Laurens Catelan, the unicorn horn's fearsome ability to make poisonous plants and creatures 'burst and die' in its presence was based on a comparable belief in the horn's occult powers of attraction and repulsion.

Similarly, the darkening of the ruby in the presence of poison or when it was turned around a pestilential lesion was caused by its absorption of the poisonous miasma of the infected body. The diamond, by contrast, detected poison in an antipathetic manner. Minute particles from the poison supposedly settled on the stone, where, unable to penetrate its hard surface, they caused a superficial discoloration. 


\section{The Power of Nature and the Agency of Art}

A dramatic and overt statement of this principle of protection by sympathetic attraction and repulsion is suggested in an extraordinary cup carved from rhinoceros horn, made for Rudolf II at much the same time as the unicorn cup, and listed in the 1607-11 inventory of his collection (Figure 1.4). ${ }^{39}$ The metalwork mounts are by an unknown Nuremberg goldsmith, while the carving of the horn has been attributed to the imperial court ivory carver, Nikolaus Pfaff (1556?-1612). Its vivid character emphasizes and enhances the material's intrinsic qualities, for rhinoceros horn, too, was believed to possess great apotropaic powers that could instantly neutralize any poisons that came near it. The horn's exterior is carved, moreover, to suggest coral, believed, from Pliny onwards, to be another powerfully protective substance (Figure 1.5).$^{40}$ Enmeshed within the coral branches, as if the embodiments of malignant forces caught in its neutralizing strands, are fierce dogs' heads, snakes, lizards, and beetles and other crawling and malign creatures ${ }^{41}$ Four human faces, two male, two female, more beneficent in aspect, half-emerge, spirit-like, from within the horn's matter. This apparent reification of the horn's occult forces is reinforced by the terrifying aspect of the mounts: the cover is in the form of a demonic dragon's face, flanked by immense horns (in fact those of an African warthog, though described in the inventory as dragon's horns (Schlangenhörner) ${ }^{42}$ a serpent's tongue or Natterzunge (in reality, a fossilized shark's tooth), set between the opened jaws, provided a further protection against poison.

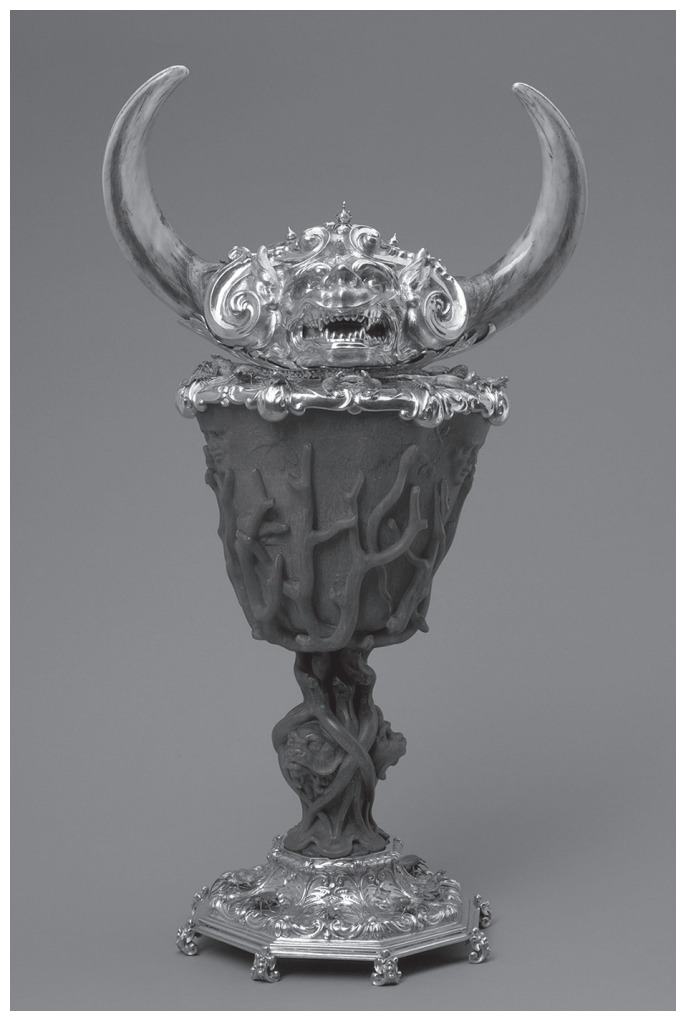

Figure 1.4 Nikolaus Pfaff, Covered Cup, rhinoceros horn, warthog tusks, fossilized shark's tooth, silver gilt, partially painted in cold colors, 1611 . Vienna, Kunsthistorisches Museum, Kunstkammer, inv. no. KK 3709. 


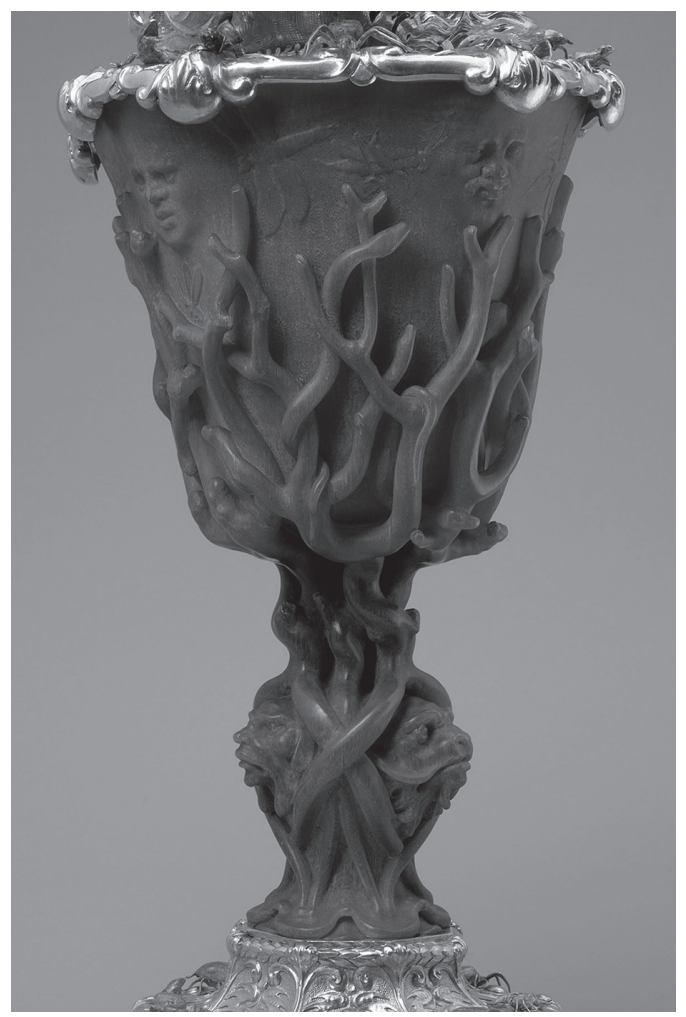

Figure 1.5 Detail of Figure 1.4.

All these additional interventions by the craftsman were undoubtedly intended to enhance the horn's innate protective powers.

Though there is no surviving account of the medical or ceremonial applications of either of these horn cups, the strong element of display in both suggests that, quite apart from functioning as objects of curiosity in the Kunstkammer, they would have been used on occasions of state. An account of the wedding of the daughter of King Edward IV to the Duke of Burgundy recounts how a unicorn horn was simply set upon the table, or near it, so that, should any poisons be present, any change in its appearance would be instantly seen. ${ }^{43}$

Thus far, all the authorities quoted took the physical evidence of the unicorn horn as fact, but with only the haziest sense of this rare creature's natural habitat as some exotic region on the borders of the known world, in India, or some foggily defined part of 'the East.' Even de Boodt, when enumerating the types of monoceroi listed by ancient and modern natural philosophers, admitted that none had been definitively identified as the 'true' unicorn. And despite his expertise in the matter, he, together with all his learned contemporaries and their princely patrons who spent such excessive sums to acquire specimens, had no idea that the characteristic long, straight, spiraling horn, universally accepted as the 'true' unicorn horn, was actually the tooth of a narwhal, a species of whale, which exists only within the very limited area of the Arctic Ocean, north of Greenland and Baffin Bay. It was - and is - seldom seen south 
of Greenland and was therefore almost completely unknown in medieval times. This curious fact begs the obvious question: how did this naturally spiraling appendage, which can grow to a length of nine feet, acquire its prodigious identity?

The purported 'eastern' origins of most of these prestige objects did not arouse mistrust among princely collectors or in learned circles. Since ancient times, Asia, and especially India, had been regarded as the rare animal's natural habitat, a tradition mediated via Aelian into the Western medieval and late medieval world. This literary tradition was grafted quite naturally onto actual horns, such that, for example, the great horn in the treasury of St Denis in Paris was thought to have been given to Charlemagne by Rashun ar Raschid, the great Abbasid Caliph, in 807 CE.44

The unicorn horn goblet of Cosimo de' Medici, Grand Duke of Tuscany, which Andrea Bacci mentioned in his treatise, L'Alicorno, of $1573,{ }^{45}$ was presented to the Grand Duke by the powerful Sephardic merchant Salomon Abenaes (1520-1603), who claimed to have received it from the king of Narsinghgarh in India. ${ }^{46}$ Abenaes was reinforcing his gift's rarity value by reaffirming an exotic provenance, which was all too believable because Abenaes - who had been born into a Portuguese converso family under the name Alvaro Mendes and officially returned to the Jewish faith in 1585 in the Ottoman Empire - had spent part of his youth mining diamonds precisely in the Indian principality of Narsinghgarh (Madras). ${ }^{47}$

In this instance one is faced with a dilemma about origins. On the face of it, it is unlikely, although not entirely impossible, that a narwhal-unicorn cup could have emanated from India. Marine ivory, including narwhal, over the centuries did filter from the polar regions via Eastern Asia and thence to Islamic countries - and perhaps as far east as India. (In this process, the more easily obtainable and truly 'eastern' rhinoceros horn became inextricably mixed up with the narwhal horn and also identified with the unicorn and its properties. $)^{48}$ Yet given the extent of his trading networks, it is more likely that Abenaes acquired his horn in the West or in the Islamic Near East, where it was an increasingly common item of trade. ${ }^{49}$

Wherever it was that Abenaes acquired the horn cup, the narwhal tusk itself was by this time part of an established trade network that originated in the Arctic Circle where Inuit hunters of the narwhal sold the tusks on to Norwegian or Danish traders. These merchants, by the second half of the sixteenth century, had a near monopoly on what had become a buoyant and highly profitable market in narwhal teeth.

If merchants exploited the belief in the unicorn horn's exotic origins transmitted by the literary tradition, the narwhal tusk's spiral character entered into the Western visual tradition in the late twelfth century and originally in England, where it is first found in a psalter of $c .1200 .{ }^{50}$ Though the details remain obscure, it seems that at this period various contingencies came together that made possible an association of the physical object with the literary tradition. The influence of the Christianized Physiologus laid the religious/spiritual groundwork that brought the symbolic association of the unicorn with Christ to prominence at the same time that the narwhal horn made its appearance in a Western market. It is significant that the earliest inventory references to ownership of narwhal-unicorn horns come from the northern European courts of England (Edward I, 1303), Burgundy (Philip of Burgundy, 1387, Charles the Bold, 1467), and France (Duke de Berry, 1418). ${ }^{51}$

At some level therefore, two parallel knowledge systems regarding the narwhal horn were at play: one was the 'learned,' text-based tradition, explored above, reinforced by a long visual iconography; the other was the baldly commercial. Indeed one 


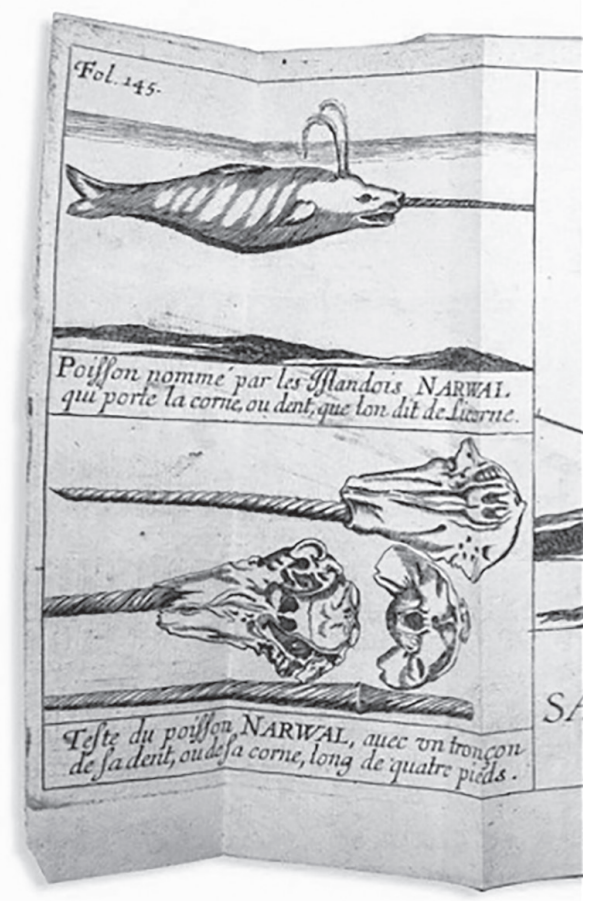

Figure 1.6 Isaac de Pleyère, Relation de Groenland (Paris: Augustin Courbé, 1647), fol. 145 .

can speak of a thread of mercantile deception that runs back to the earliest trade in the material but which was increasingly difficult to maintain by the later sixteenth century. Under pressure of naturalists' investigations, exploration and trade in the Polar Regions, the spread of knowledge networks, and what appears to have been a glut in the market of narwhal tusks that accompanied an expansion of the Greenland fishing trade, belief in the unicorn horn and its natural powers became increasingly difficult to sustain. The man who published the first explanation of the narwhal and its tooth was the Danish naturalist Olé Worm. He vividly described his discovery in a letter to the Frenchman Isaac de Pleyère, recorded in the latter's Relation de Groenland written in 1646: how the Chancellor of Denmark, Christian Fries, showed him a narwhal skull with the 'horn' still attached; how he had an artist make a scale drawing of it; and how, upon acquiring another entire specimen, he realized that the horn was in fact an enormous tooth (Figure 1.6).

Worm's account also sheds rare light on the attitudes of the merchants of narwhal horn, starkly revealing the existence of these parallel worlds:

The Danes are of opinion (as most certainly it is), that all those kind of horns found in Muscovy, Germany, Italy, and France, came originally out of Denmark, where this sort of merchandise was very frequent, whilst there was a passage between Norway and old Greenland, and that they constantly crossed the seas from one coast to the other. The Danes, who brought them to sale in foreign 
countries, had no reason to declare them to be fishes' teeth, but sold then for unicorns' horns, to sell them at a higher rate; this they . . . continue to do it to this day. 'Tis not long since, that the Company of New Greenland, at Copenhagen, sent one of their agents into Muscovy, with several great pieces of these kinds of horns, and amongst the rest, one end of a considerable bigness, to sell it to the Great Duke of Muscovy. The Great Duke being extremely taken with the beauty thereof, he showed it to his physician, who, understanding the matter, told him 'twas nothing but the tooth of a fish; so that this agent returned to Copenhagen without selling his commodity. After his return, giving an account of the success of his journey, he exclaimed against the physician who spoiled his market by disgracing his commodities, 'Thou art a half-headed fellow' replied one of the Directors of the Company: 'Why didst thou not offer two or three hundred ducats to the physician, to persuade him that they were the horns of the unicorn?'52

For the craftsman Hans Vermeyen, his patron, Rudolf, and his learned circle of physicians and natural philosophers, all this lay invisibly in the future. For them, the occult powers of the unicorn horn were all too palpable, to be investigated and understood through collecting, scrutiny and the study of ancient authority as with de Boodt, and controlled and manipulated through the art of Vermeyen. For all that they were working in the dark, their common aspirations reveal the possibilities of advancing knowledge that the context of the Kunstkammer offered and which were to pave the way for Olé Worm's later discoveries. Above all was the sense that, implicit in works like those of Vermeyen or Pfaff and their fellow craftsmen, was the idea that human ingenuity could comprehend, harness and even challenge the existing order of nature. The rivalries between human and natural energies that were explored in the workshops and collections of the later sixteenth century were ultimately to give rise to the culture of experiment and curiosity of the following century. Already, by the later sixteenth century, cracks in the older edifice of knowledge of the unicorn had begun to show. The physician, Andrea Marini, wrote a tract as early as 1566 that exposed flaws and inconsistencies in the traditional accounts of the unicorn. ${ }^{53}$ Even Bacci, whose treatise was likely commissioned by Francesco de' Medici precisely to defend the unicorn against detractors like Marini, and who argued from a deep well of learning, reveals an exhaustion with this intellectual tradition. He finished his book with the remarkable assertion that:

Whether the alicorn sweats or does not sweat, whether it makes water boil or does not make it boil, the belief that it does so will do no injury to truth and will be for the good of the state. No man of sound mind should seek to disprove these things by rigor of reasoning, but should allow and discreetly admit them - for the sake, at least, of the Princes whom they will please by such favorable opinion. Thus the common good obliges us to write and to persuade the ignorant that what is said of the Alicorn is true, because such belief discourages wicked men from evil doing by making them think that the virtue of this horn will easily discover their iniquity and bring about their utter ruin. ${ }^{54}$

In this tacit admission that his model of 'truth' was based upon social and political expediency rather than on scientific conviction (con rigor dell'ragione), Bacci shows the inadequacy of a framework of truth which 'men of sound mind' (alcun [i] di sano 
intelletto) were increasingly unable to accept. In this respect, the Kunstkammer, the works it contained and those craftsmen, physicians and natural philosophers who worked within its orbit, stood at the cusp of two eras, a place where one could glimpse, at the junctures of practical and theoretical knowledge, of the wondrous and the empirical, of credulity and curiosity, the gradual emergence of a new order amid the slow passing of the old.

\section{Notes}

1 Andrea Bacci, L'Alicorno. Discorso dell' eccellente medico, et filosofo M. Andrea Bacci: nel quale si tratta della natura dell' alicorno, \& delle sue virtù eccellentissime . . . (Florence: Giorgio Marescotti, 1573), 18, 51.

2 The ideas in this article grew out of a seminar on the arts of the Kunstkammer that I have taught in various iterations over a number of years at the Bard Graduate Center. I wish to warmly acknowledge all the students who have contributed ideas, in particular Marnie Stark, Kate Tahk, Liz Neil, and Miranda Pildes, whose MA thesis on the decorative arts of Rudolphine Prague and the occult I reference below.

3 The indispensable works on the subject are still Odell Shepard, The Lore of the Unicorn (New York: Dover, 1992 (first published 1930)) and Guido Schönberger, 'Narwal-Einhorn. Studien über einer seltenen Werkstoff,' Städel Jahrbuch 9 (1935-6), 167-247.

4 Vienna, Kunsthistorisches Museum, Kunstkammer, inv. no. KK 1113. See Arpad Weixlgärtner, 'Die Weltliche Schatzkammer in Wien. Neue Funde und Forschungen II,' Jahrbuch der Kunsthistorischen Kunstsammlungen in Wien, Neue Folge 2 (1928), 297-300; and most recently, Rudolf Distelberger, 'Kunstkammerstücke,' in Prag um 1600. Kunst und Kultur am Hofe Kaiser Rudolfs II, exhib. cat, Vienna, Kunsthistorisches Museum (Freren: Luca Verlag), 1988), 3 vols, 1, 471-2.

5 Ibid.

6 Ibid., 472-5.

7 Ibid., 471. Distelberger cites the Matthiasinventar 1619, $\mathrm{Nr} 899$; significantly, the cup is listed directly after the entry made for the crown.

8 See Thomas DaCosta Kaufmann, 'Remarks on the Collection of Rudolf II: The Kunstkammer as a form of Representatio,' Art Journal 38 (1978), 22.

9 Joseph Nigg (ed.), The Book of Fabulous Beasts: A Treasury of Writings from Ancient Times to the Present (New York: Oxford University Press, 1999), 116-20.

10 Schönberger, 'Narwal-Einhorn,' 234-7.

11 Nigg, Fabulous Beasts, 118.

12 Jahrbuch der Kunsthistorischen Sammlungen in Wien 26 (1906/7), XVII, Regest. 19454.

13 Distelberger, Prag um 1600, 449.

14 See Joan Evans, Magical Jewels of the Middle Ages and the Renaissance (Oxford: Clarendon Press, 1922, repr. New York: Dover, 1976).

15 George Frederick Kunz, The Curious Lore of Precious Stones (New York: Dover, 1989), 69-70, 95 .

16 Cited in Shepard, Lore of the Unicorn, 82.

17 For Camillo Leonardi, the agate conferred victory and strength (Speculum lapidum (Venice: Sessa, 1502), fol. 22); while for Girolamo Cardano, the agate made the wearer, 'temperate, continent, ... and more prudent in his actions' (Hieronymi Cardani, Opera omnia (Lugduni: Huguetau \& Ravaud, 1663), vol. 2: De gemmis et coloribus [1st ed.1563], 324 and vol. 3: De subtilitate libri XXI [1st ed. 1550], 460.). See Kunz, The Curious Lore, 51-2; and Miranda Pildes, Ars Melancholia: An Investigation into the Formal and Occult Virtues of Rudolfine Decorative Arts (unpublished MA thesis: Bard Graduate Center, 2002), 108.

18 Distelberger (Prag um 1600, 1, 472) suggested that the helmeted female head represents Venus, yet the helmet is the attribute of Athene /Minerva, the goddess of Wisdom. The pairing of Mars and Minerva (Strength/War tempered by Wisdom/Prudence) was a common topos of Rudolphine Prague. See Thomas DaCosta Kaufmann, The School of Prague. Painting at the Court of Rudolf II (Chicago and London: University of Chicago Press, 1988), passim, and esp. 44, 64, 92, 262. 


\section{The Power of Nature and the Agency of Art}

19 Vienna, Kunsthistorisches Museum, Kunstkammer, inv. no. ANSA XII 819. Pildes, Ars Melancholia, 108, discusses this work in relation to the female figure on the obverse of the unicorn cup's finial, which she interprets as Prudence.

20 Anselmus de Boodt, Gemmarum et lapidum hboodt gemmarumistoria (Hannover: Marne \& Aubry, 1609), book 2, chapter 4, 61-3).

21 Evans, Magical Jewels, passim.

22 Suger, Abbot of Saint Denis, On the abbey church of St.-Denis and its art treasures, ed., transl, and annot. by Erwin Panofsky and Gerda Panofsky-Soergel (Princeton: Princeton University Press, 1979). The treasures Suger described are known today only in the engraving in Dom Michel Félibien, Histoire de L'Abbaye Royale de Saint-Denys en France (Paris: Leonard, 1706).

23 De Boodt, Gemmarum, Dedication, 7.

24 R. J. W. Evans, Rudolf II and his World. A Study in Intellectual History, 1576-1612 (Oxford: Clarendon Press, 1973), 217.

25 De Boodt, Gemmarum, 429.

26 De Boodt, Gemmarum, book 2, chapter 141, 209-15.

27 Shepard, Lore of the Unicorn, 34-5.

28 Weixlgärtner, 'Weltliche Schatzkammer,' 285-7.

29 De Boodt, Gemmarum, book 2. chapter 14, 73.

30 Ibid., book 2, chapter 4, 61 .

31 Ibid., book 2, chapter 97, 125.

32 Ibid., book 2, chapter 4, 62-3.

33 Ibid., 63.

34 See the discussion in Pildes, Ars Melancholia, 109-10.

35 Shepard, Lore of the Unicorn, 130.

36 Ibid., 290, note 97.

37 Catelan, Histoire de la nature, chasse, propriété et usages de la lycorne (Montpellier: J. Pech, 1624), quoted in Shepard, Lore of the Unicorn, 117-8.

38 On plague amulets and Croll's zenexton in particular, see Martha Baldwin, 'Toads and Plague: Amulet Therapy in Seventeenth-Century Medicine,' Bulletin of the History of Medicine 63 (1993), 227-47.

39 Vienna, Kunsthistorisches Museum, Kunstkammer, inv. no. KK 3709.

40 Elizabeth Scheicher, 'Zur Ikonologie von Naturalien im Zusammenhang der enzyklopädischen Kunstkammer,' Anzeiger des Germanischen Nationalmuseums (1995), 118, note 27.

41 Ibid., 121-3. Scheicher related the dogs' heads to Pliny's account of the Cynocephali, the dog-headed inhabitants of India, and characterized the coral and other elements of the decoration as evocations of India.

42 Rotrand Bauer and Herbert Haupt, 'Das Kunstkammerinventar Kaiser Rudolf II, 1607-1611,' Jabrbuch der Kunsthistorischen Sammlungen in Wien 72 (28) (1976).

43 Shepard, Lore of the Unicorn, 133-4.

44 Schönberger, 'Narwal-Einhorn,' 197-8.

45 Bacci, L'Alicorno, 55.

46 Daniel Jütte, The Age of Secrecy Jews, Christians and the Economy of Secrets, 1400-1800 (New Haven, CT: Yale University Press, 2015), 81-2.

47 Ibid.

48 Jeannie Thomas Parker, The Mythic Chinese Unicorn (Victoria, Canada: Friesen Press), 2013.

49 Several examples of narwhal horn in Western collections have genuinely eastern provenances. One of the three unicorn horns in the treasury of San Marco in Venice has Arabic engraved inscriptions on mounts, invoking Allah and the seven prescribed daily prayers of Islam, dateable to the thirteenth century. A second example with a Greek inscription originated in Constantinople. See Schönberger, 'Narwal-Einhorn', 167-247, 197-8.

50 Ibid., 194.

51 Shepard, Lore of the Unicorn, 110.

52 Isaac de Pleyère, Relation de Groenland (Paris: Augustin Courbé, 1647). Cited in David Cranz, The History of Greenland: including an account of the mission carried on by the United Brethren in that country (London, 1820), 105, note 9, 321-3.

53 Discorso de Andrea Marini, Medico, Contra la Falsa Opinione dell'Alicorno (Venice: Aldus Manutius, 1566).

54 Bacci, L'Alicorno, 79-80. 


\title{
2 Late Medieval Enclosed Gardens of the Low Countries ${ }^{1}$
}

\author{
Mixed Media, Remnant Art, Récyclage \\ and Gender in the Low Countries \\ (Sixteenth Century Onwards)
}

\author{
Barbara Baert, Hannah Iterbeke \\ and Lieve Watteenw
}

The early sixteenth-century Enclosed Gardens or horti conclusi of the Augustinian Hospital Sisters of Mechelen form an exceptional world heritage collection from the late medieval period (Figure 2.1). Most Enclosed Gardens have been lost to the ravages of time, with this loss exacerbated by lack of both understanding and interest. No fewer than seven Enclosed Gardens, however, were preserved until the late twentieth century in their original context, that is the small community of Augustinian nuns in Mechelen. ${ }^{2}$ Like sleeping beauties, they remained secluded in the sisters' rooms as aids to devotion. Their centuries-long slumber has recently given way to a new phase of a lively debate and active scholarship, as these popular retables are now considered unique testimonies of female spirituality in the sixteenth century. Their remarkable pictorial vernacular provides new insights into life, thought and devotion in female convent communities. They testify to a cultural identity connected with strong mystical traditions; they are a gateway to a lost world, an essential part of the rich material and immaterial culture of the Southern Netherlands in the early sixteenth century.

The flowers and the embroidered wrappings around objects like stones, medallions and relics in the Enclosed Gardens were created by the religious with subtle refinement and an astonishing range of effects. With silk and precious silver threads, nuns twisted knots and patterns over armatures of fine parchment, incorporating glass beads, paper quilling (paperolles), semi-precious stones and sequins. Artificial flowers and fruit, especially branches of wild roses, white lilies and pink grapes, surround the wooden statuettes known as Poupées de Malines (dolls of Mechelen), relics, wax medallions and small pipe-clay figures. ${ }^{3}$ At the back of the wooden box containing each garden, dense lozenge patterns are created with webbed threads stitched over the rolls of silk. Unparalleled focus went into creating these items of extremely fragile cultural heritage from a large variety of materials. Many of the materials used are rarely seen in surviving examples of late medieval craftsmanship; their presence in such complex combinations makes the Enclosed Gardens a fascinating collection of mixedmedia creations. Exploring, contextualising and preserving these objects is thus both uniquely challenging and stimulating. ${ }^{4}$

Only recently have Enclosed Gardens, as a genre, come to be acknowledged and recognised as a worthwhile field of study. As they are typically seen as hybrid objects, they defy accepted terminology and conventions in research into medieval material devotional culture. In the 1990s, drawing on gender studies and the 'anthropological turn', Jeffrey Hamburger, Miri Rubin and Paul Vandenbroeck pioneered the effort to recontextualise the genre. ${ }^{5}$ Today, Enclosed Gardens are approached as multivalent 


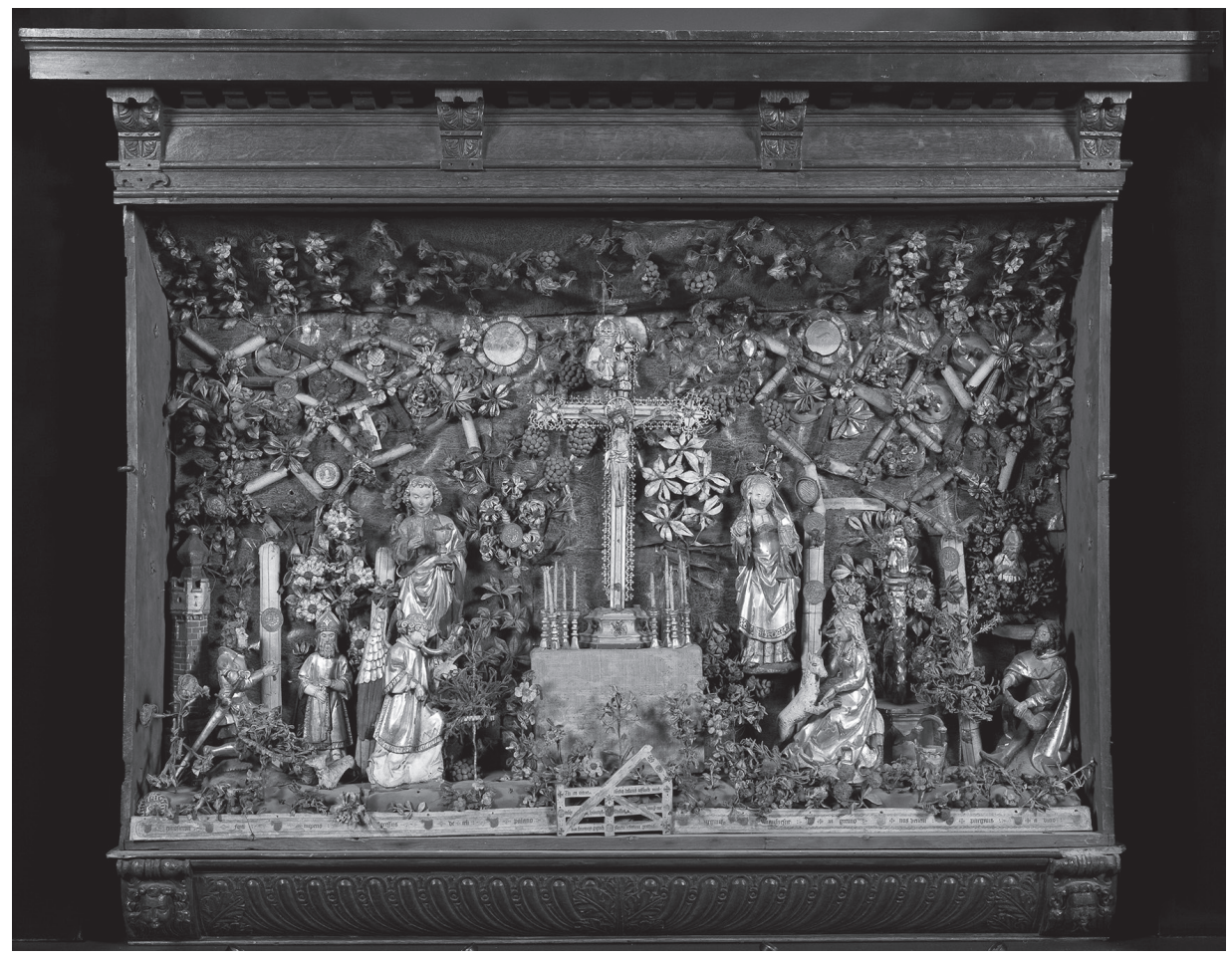

Figure 2.1 Anonymous, Enclosed Garden with Calvary and Hunt on the Unicorn, mixed media, 1510-20, $124 \times 158.4 \times 33 \mathrm{~cm}$. Mechelen, Museum Hof van Busleyden.

artefacts whose purpose lies somewhere between retable and domestic furniture. They most probably played a part in the nuns' private lives as well as in communal life at the convent. ${ }^{6}$ Moreover, as they contain relics and a variety of 'lesser' remnants, such as stones, bones and even bags of sand, they may also be seen as shrines. Perhaps Enclosed Gardens can even be conceptualised as cabinets of curiosities whose contents convey the character and spirituality of the religious women who assembled them. ${ }^{7}$

In what follows, we discuss these gardens as a threefold type of horticulture: (1) a symbolisation of Paradise and a sanctuary for interiorisation (Barbara Baert); (2) a sublimation of the sensorium in reference to the making of the flowers (Hannah Iterbeke); and (3) as a complex conservation process (Lieve Watteeuw).

\section{Paradise, Hofje, Sanctuary}

The Dutch word hof means not only 'court' or 'courtyard' but also 'garden', and hence is associated with the archetypal paradise (Dutch paradijs), which in turn has semantic roots in the Persian language and culture: the (unattested) Old Persian word for paradise is paridoeza, rendered in Greek as peri ('around') teichos ('wall'). ${ }^{8}$ Thus hof means garden, and at once referring to the enclosed garden of the convent itself, 
and more specifically to its inner courtyard - also known as the garden of paradise where water spouts from a fountain and flowers bloom. ${ }^{9}$ Enclosed Gardens also, most importantly, refer plastically to the Song of Songs, in which a man and a woman express their desire for one another in the Garden of Love. ${ }^{10}$ The groom invites the bride and says (5:1): 'I have come into my garden, my sister, my bride / I have gathered my myrrh with my spice / I have eaten my honeycomb and my honey / I have drunk my wine and my milk.'

The Song of Songs was interpreted from the time of the earliest Church Fathers as an allegory of mystical love. ${ }^{11}$ Scholars identified the marriage between the bride and groom with the union between Christ and his bride Ecclesia. To Bernard of Clairvaux (1090-1153) the opening kiss of the Song of Songs - Osculator me (Let him kiss me) was the mystical kiss and an image of Christ who has become man, the word that has become flesh. 'Then, at last - with fear and trembling I say it - perhaps, then, we may venture to raise ourselves to that divinely glorious Mouth, not merely to contemplate its beauty, but even to enjoy its kiss,' he writes in his Sermons on the Canticle of Canticles. ${ }^{12}$ As the bride of Christ, the spiritual woman could relate to such exegetic interpretations of the Song of Songs and its spiritual application within a mysticism of love. ${ }^{13}$ Artistically, too, the Song of Songs became her principal iconographic source, ${ }^{14}$ including in relation to Enclosed Gardens, where feminine spirituality is veiled with flowers and sublimated into an intimate and highly personalised topos of love, with found objects serving as a mysteriously concealed catalyst.

The enclosed garden becomes a metaphor for immaculacy, purity and virginity, as well as paradise, where, prior to the Fall, all was perfect. It serves as a plastic pars pro toto for paradise and as a medium for interiorising this metaphor of purity. Enclosed Gardens provide a means for locating and entering the immaculate 'place' in one's soul. In this sense, the genre ties in with the late medieval spiritual exercises described in certain sermons and now commonly referred to as 'interior allegory' on the one hand and as 'virtual pilgrimage' on the other.

The interior allegory is based on a mental technique whereby viewing a painting becomes like stepping into the (pictorial) reality and the spiritual experience of the interior. ${ }^{15}$ The vernacular texts describing the technique display an interesting affinity with the notions of a 'room' and a 'garden'. The faithful are to project the lessons onto their own room, and to take its spare interior, furnished only with a bed, chair and candlestick, as a spiritual point of departure: 'Near the bed is found peace and rest for the conscience; by the table penitence; by the chair a judgment of himself; and by the candlestick a confession of himself' (De doctrina cordis, fifteenth century). ${ }^{16}$ Some sermons and instructions even go into detail with regard to the bed linen, the food on the table and the decoration of the space with flowers, as developed by Bernard of Clairvaux in relation to the Annunciation. To enter the room is to enter the mystical heart. Mary's room, where the angel enters - and by extension where we enter - is described as having been decorated with pleasing flowers and herbs with a delicious perfume. ${ }^{17}$ Such descriptions are often intertextual references to the Song of Songs, in which the bride and bridegroom experience their love in a room.

In her book Virtual Pilgrimages, Kathryn M. Rudy presents a convincing case for her hypothesis that Enclosed Gardens, in their capacity as 'interior allegory', actually constitute a vehicle for undertaking a mental journey to Jerusalem (or, by extension, to any holy place), without physically travelling. ${ }^{18}$ Examples of such 'virtual pilgrimages' are found in a genre of manuscript in which holy places are visualised and described 
so that they could be 'visited' mentally. Enclosed Gardens can similarly mediate a spiritual journey to a physically unreachable destination, as one strolls through the garden and playfully searches for the natural objects hidden in the shrubs, and experiences delight at whatever treasure one finds (a relic, a souvenir). Rudy writes: 'To enter them visually is to be mesmerized by their dizzying array of flowers. To move in their first layer of interpretation is to penetrate the garden fence using prayer as a vehicle. Entering the box, the viewer enters the Holy Land on the scale of a dollhouse, an idealized microcosm of female enclosure. ${ }^{19}$

Enclosed Gardens have their own creative horticulture: a continuum of growth, in which the actual creative process serves as the signifier: wrapping, turning, embroidering, sewing, attaching, detaching, applying, weaving, clumping, tucking, tacking, crocheting, plugging, folding, rolling, etc. In short, in the universe of Enclosed Gardens, creative hands manifest themselves as subordinate and corporeal conduits of a deeper significance. ${ }^{20}$ Enclosed Gardens touch on an écriture that pays homage to decentralisation, fragmentation, proliferation, fluttering contours and the ungraspable. Embroidering, bobbining, knotting, turning, enveloping and the entire semantic field constitute the corporeal variationes on what happens when fingertips come into contact with threads. ${ }^{21}$ In the following sections we will focus on the making and meaning of silk flowers on the one hand (by Hannah Iterbeke) and on specific conservation problems on the other (by Lieve Watteeuw).

\section{Silk Flowers, Triggers for Devotion}

Some of the most remarkable elements of the mixed-media texture of the Enclosed Gardens are their silk flowers. These flowers can be studied as a pars pro toto for a better understanding of the production and function of the Enclosed Gardens. Who created these silk flowers? And what is their actual function within their devotional setting? Are they merely an iconographical reference to the paradisiacal garden of the Song of Songs or could they be triggers for a far more complex spiritual exercise? Generally, the flowers are considered the result of female devotional handiwork made within the walls of the convent. ${ }^{22}$ To get a more nuanced view on the making and meaning of these silk flowers - and the Enclosed Gardens - the possibility of male involvement as well as a commercial incentive must be taken into account. ${ }^{23}$

In his Die Kunstblume von der Antike bis zur Gegenwart (1957), Bruno Schier states that the art of making silk flowers can be attributed to both nuns and craftsmen. ${ }^{24}$ Furthermore, the author argues that the production of silk flowers dates back to the Middle Ages. In this period, according to Schier, silk flowers were the result of Klosterarbeit mainly in Italy and were used to decorate altarpieces and statues of female convents. In a later stage these artificial flowers became a product for export. ${ }^{25}$

Consideration of two production circumstances for this sort of handiwork leads to possible answers regarding the making of silk flowers: the male craft of the passementmakers and the virtuous labour of devoted women such as the beguines of Mechelen. Considering the technical difficulties related to the making of these flowers there were likely few people within Mechelen who had the technical knowledge necessary for their production.

The craft of the passementmakers dates back to the fourteenth or fifteenth centuries and was not represented by a guild. It is usually grouped with other crafts such as ribbon making or needlework but the categorisation differs in every city. The passementmakers 
made all kinds of textile works, such as embroidery and ribbons. They may have even made silk flowers as seen in the Enclosed Gardens. Considering the fact that the sculptures and painted panels were both made by male workshops, the flowers may come from a male production as well. ${ }^{26}$ The question of female involvement within the creation of these Enclosed Gardens then arises.

Although many of the objects included within the Enclosed Gardens were made by men, the creation of an Enclosed Garden as a whole likely involved religious women. An account of Margret of Austria, published by Alexandre Pinchart, tells us about the involvement of the well-known Gerard Horenbout, one of her court illuminators, in the making of a Jardinet Clos. ${ }^{27}$ For this assignment, Gerard Horenbout, who lived in Ghent at the time, had to stay at the sisters' priory of Gallilee of Ghent. While this account does not prove that the sisters were actively concerned with the production of the Enclosed Garden, it does demonstrate a connection between the production of Enclosed Gardens and female religious orders, as if they were the ones giving spiritual meaning to the objects of devotion.

A second circumstance in which the silk flowers could have grown is behind the walls of the beguinage of Mechelen. These religious women were actively concerned with the production and sales of textiles. ${ }^{28}$ But the beguines of Mechelen also worked with silk, as proven by a painting of the activities of the beguines from the midsixteenth century (Figure 2.2). ${ }^{29}$ The painting shows how beguines made silk ribbons

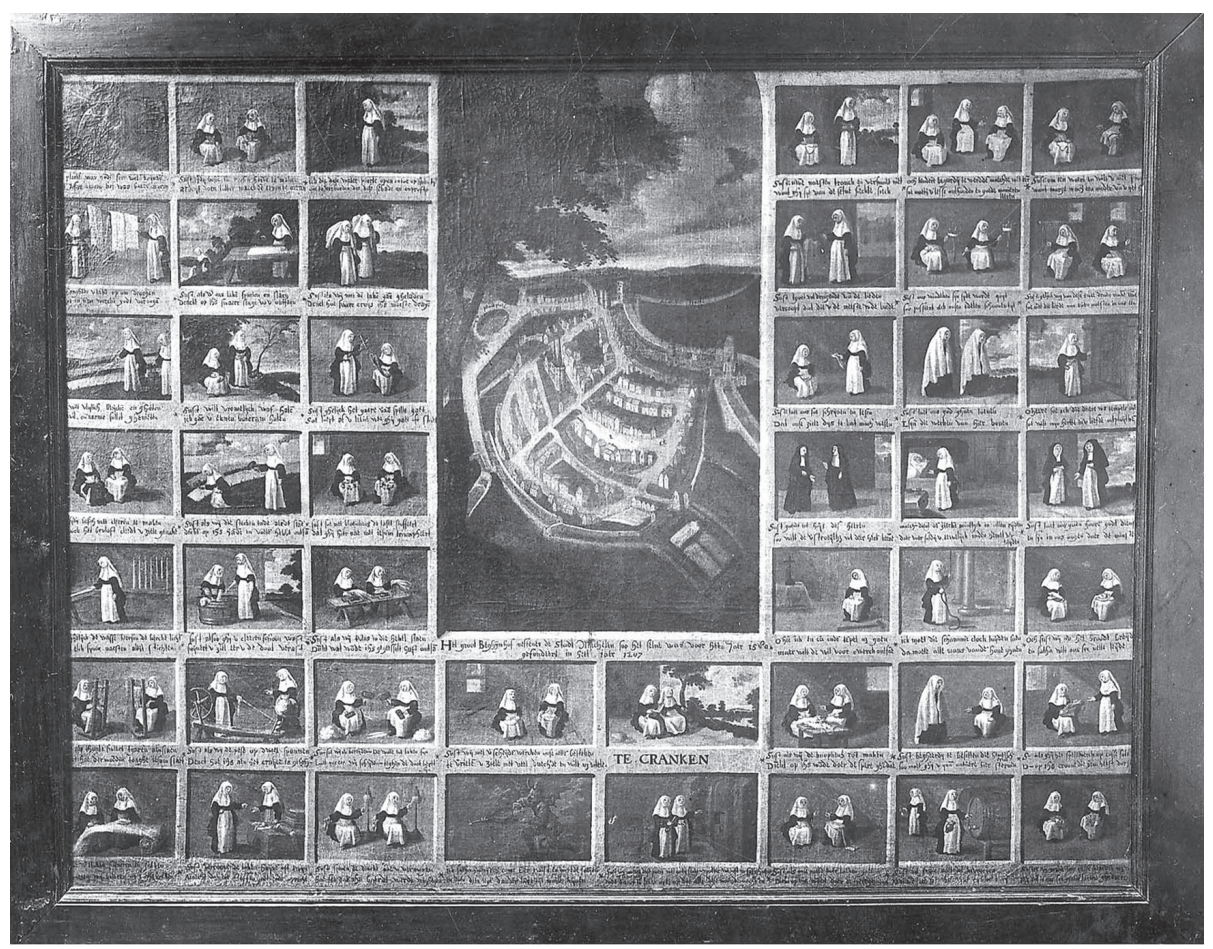

Figure 2.2 Anonymous, View of the Court Béguinage of St. Catherine in Mechelen, oil on paper, 1500-1600, $114 \times 150 \mathrm{~cm}$. Mechelen, Museum Hof van Busleyden. 
even though ribbon making was a craft of the aforementioned passementmakers. The panel shows 46 compositions in which the lives and activities of the beguines are portrayed. Several scenes depict two sisters working with flowers, silk and embroidery. Inscriptions accompanying these scenes first explain the labour illustrated and then connect this labour with its spiritual reward. For example: 'Sister are you busy, making rosaries, work unto the virgins holy crown to reach. ${ }^{30}$ Could they be working on the silk flower crowns as worn by the beguines during ceremonies or as those seen on the skulls of Herkenrode (Figure 2.3)?

The connection between physical work and spiritual labour can also be found as a topos within sixteenth-century devotional literature. It was believed that handiwork counteracted idle gossip and other sins. This labour thus protected the devout women from sin and helped them to cultivate their virtues and spiritual insights. The creation of silk flowers in the Enclosed Gardens can be understood as an active interpretation of the imagery in devotional literature, such as Thoofkijn van devotien or Den gheestelijcken boomgaert, which described the path of spiritual insights with the state of unio mystica as its final destination. ${ }^{31}$ The Thoofkijn van devotien tells us that Christ receives crowns braided from the virtuous flowers of his sisters. ${ }^{32}$

The connection between virtue and spiritual labour can be found in the figure of the Virgin Mary, the ultimate model for these women. The devotion to Mary led to imitatio Mariae, a practice in which the sisters imitated the labour and lifestyle of

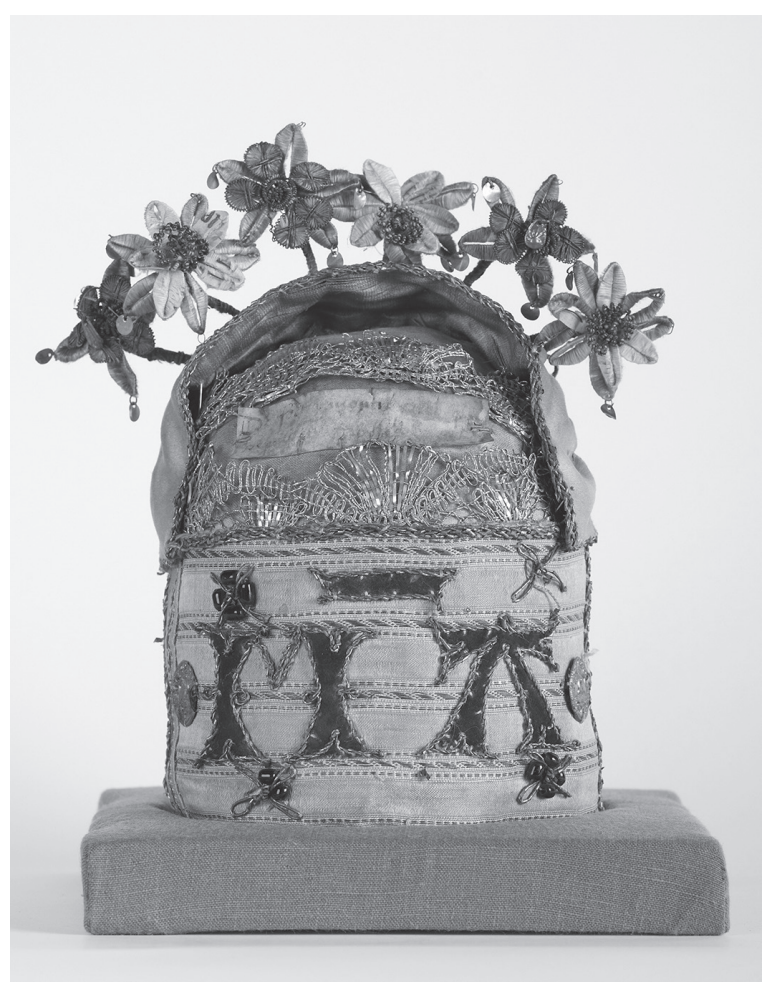

Figure 2.3 Anonymous, Skull Relic of Herkenrode, mixed media, 1400-1800, $160 \times 358 \mathrm{~cm}$. Hasselt, Sint-Quintinuskathedraal. 
the Virgin. But this imitation was not one-sided. A religious folk legend attributes the making of silk flowers to the Virgin Mary. In this legend the Christ child asks for flowers, and since it is winter and there are no flowers, the Virgin starts making textile ones herself. ${ }^{33}$ The precise origins of this legend are unknown but it is possible that the story arose from the very activity of making flowers conducted by religious women instead of the other way around. By attributing this artistic practice to the Virgin, the religious women attained a level of imitatio Mariae. This legend suggests that the making of silk flowers can be seen as a spiritual labour and an act of love and devotion towards Christ.

The connection between the flower as motif and the silk flowers as a result of the spiritual labour of devoted women can be found within the notion of virtue. Flowers have several qualities, including colour, species and smell, that can carry meanings and give significance to the context in which the flowers are presented. There is an interaction between the flower obtaining a meaning from its context and the flower adding meaning to this same context. The positioning of a white lily next to a statue of Mary Magdalene projects the purity it symbolises onto the sinner-saint Mary Magdalene in the Enclosed Garden (Figure 2.1). ${ }^{34}$ The connection between a virtue and a flower goes beyond the species of the flower. In the sixteenth century, a virtue can adopt the qualities of flowers. This adoption can be found in devotional literature in which smell plays a remarkable role. The virtues are described as sweet smelling. Therefore, relics of a perished but righteous saintly person are described as scented. However, not only virtue is sweet scented, for ultimate knowledge is perfumed as well. This scent can be perceived by the physical as well as by the inner senses. Beholding a flower with the physical senses can be a trigger for smelling the sweet scent of this same flower with the inner senses. It is this collaboration of the senses, or synaesthesia, that influences the gaze of the female devout beholding the Enclosed Gardens. ${ }^{35}$

The Enclosed Gardens of Mechelen evoke the relation between virtuous labour, flower, virtue, smell and relic. Considering the anamnestic capacity of smell, the flowers in the Enclosed Gardens can remind the devoted of paradise and give insights into a higher knowledge that leads to the unio mystica. It is as if the smell of virtuous labour diffused by the silk flowers lifts the devoted up from the earthly material world into a paradisiacal, immaterial world beyond the Enclosed Garden.

\section{Making and Keeping the Garden: Material Culture Reflected and Conserved}

Just how many Enclosed Gardens were created in the late fifteenth and early sixteenth centuries in Mechelen and the Low Countries is unknown, as most were destroyed as the result of numerous religious and political conflicts from the sixteenth to the late eighteenth centuries. Certainly, the seven surviving horti conclusi in Mechelen are rare spiritual and material testimonies of a living tradition of the Augustinian hospital sisters, which escaped destruction thanks to the close involvement and protection of the community. Until the late twentieth century they were kept in the living space of the sisters as facets of their spiritual life. To the Augustinian nuns, the daily care for the 'artificial gardens' was a religious labour and responsibility.

To reflect on their material life and to gain knowledge of the sources, the creation and the exquisite craftsmanship of the Hofkens, an interdisciplinary research and conservation project was established in 2014 as a collaboration of the University of 
Leuven - Illuminare - Centre for the Study of Medieval Art and the Museum Hof van Busleyden in Mechelen and the laboratories of the Royal Institute of Cultural Heritage in Brussels. Eight specialised conservator-restorers were appointed to treat the complex objects (2014-18). ${ }^{36}$

As described in the introduction above, the Enclosed Gardens are five-hundredyear-old highly complex mixed-media ensembles of small artefacts in organic materials such as silk, parchment, paper, bone (human and animal), pipe-clay, wax and plant fibres. Inorganic materials are also used: glass, pearls, coral, semi-precious stones, crystal, gold, silver and brass wire. The Poupées de Malines are accompanied by more than three hundred clusters of silk flowers and vegetation in green, red, pink, white and orange. Each leaf of a flower or branch is a meticulous construction: a brass metal thread is wrapped with a primary silk yarn. These covered brass files are integrated in parchment slips to shape and curve them, and then twined around with silk thread to create the petals. Different shapes and colours are created to form different types of flowers, like roses and lilies. A group of ten to fifty petals are organised in a circular way around a core, and their metal supports are used to create the stem. Glass pearls, beads and quillings are added during the creation of the flower. The flower branches are pricked on the bottom of peat (turf) covered with green silk and placed in a skilfully made and sculpted wooden box of Baltic oak. ${ }^{37}$ The hundreds of flourishing elements creating the paradisiacal garden are attached to each other with extremely thin metal and flax threads and suspended through small holes in the primary wooden support. ${ }^{38}$

All these artefacts have suffered considerable natural decay during the last five hundred years. Their material provenance is straightforward: we see that the nuns cared for their 'paradise gardens' as they kept moving them to their new venues in Mechelen. ${ }^{39}$ Historic interventions reveal the nuns' ongoing care for the objects: replacing and overpainting missing statues (eighteenth century?), adding protective glass in lead (early nineteenth century?), rewrapping the brocade silk plant stems (paperollen) with linen (early twentieth century), redecorating the damaged backing paper (late nineteenth or early twentieth century) and fixing fallen artefacts with glue, nails and staples (mid-twentieth century).

Although the sanctuaries were protected with wooden shutters during daily life, this could not prevent considerable damage. The condition assessments, laboratory and imaging techniques (RX, colour measurements, fibre analyses, non-destructive Xrf, Reflectance Transformation Imaging and aging simulation) executed on the Enclosed Gardens and the artefacts in the retables reveal the extreme fragility of the ensembles (Figure 2.4). ${ }^{40}$ The plans for long-term conservation and preservation of these rare historic mixed media are being developed by a multi-disciplinary team of art historians, conservation and imaging scientists and conservator-restorers. The main aim is to document, research and conserve the 'homelike shelter' of these sleeping beauties in a scientific and engaging way for the next generations. The project will come to a conclusion in 2018 when the seven Enclosed Gardens will be on display in the renovated sixteenth-century Hof van Busleyden.

\section{By Way of Conclusion: Framing a Nest}

The Enclosed Gardens retain their distance by conforming to the familiar genre of the 'retable', the 'piece of furniture', the Wunderkammer. The framing imposes a sense of 


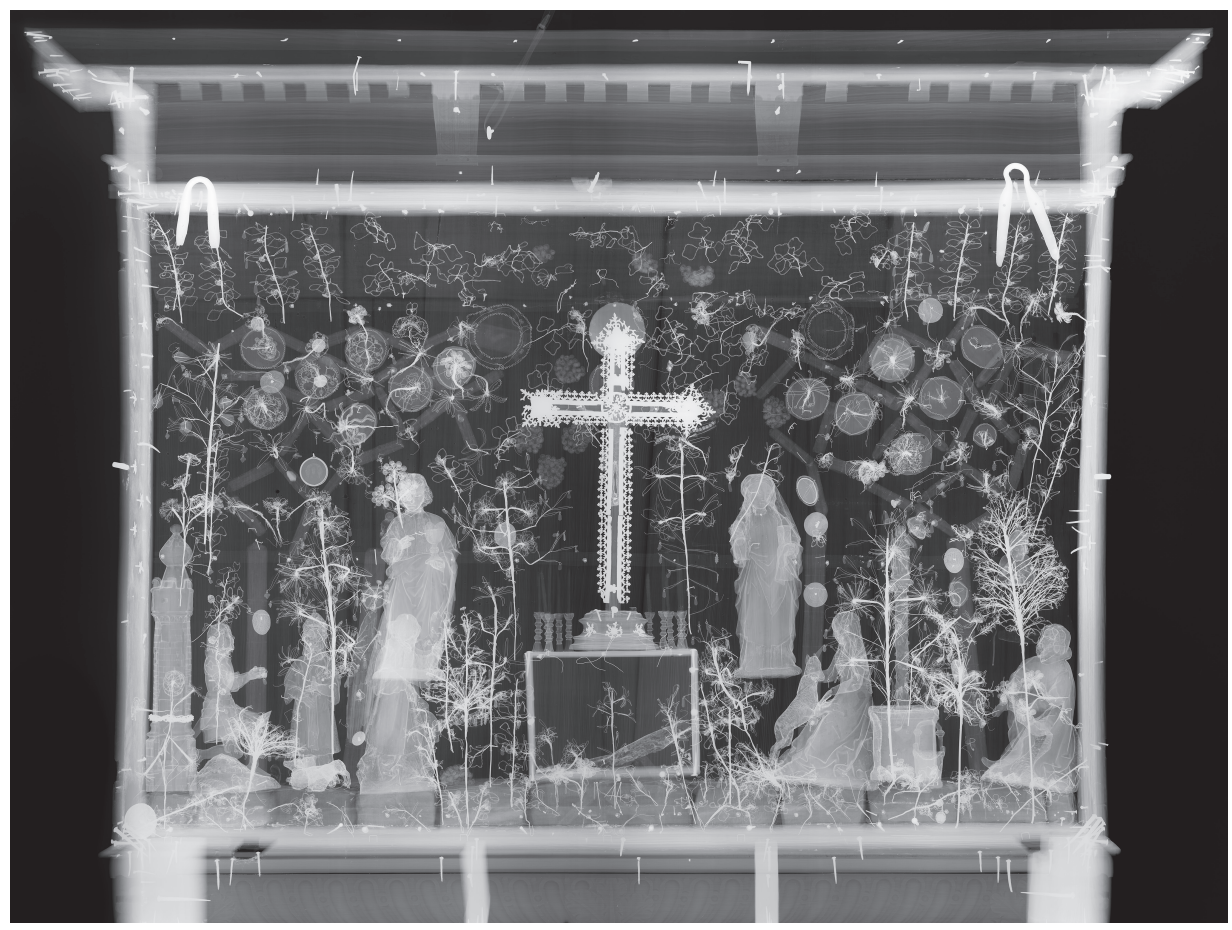

Figure 2.4 Anonymous, Enclosed Garden with Calvary and Hunt on the Unicorn (X-Ray), mixed media, 1510-1520, $124 \times 158.4 \times 33 \mathrm{~cm}$. Mechelen, Museum Hof van Busleyden.

delimitation, indicating that Enclosed Gardens are not wild, unkempt slices of nature. This makes them horticulture indeed, and not wilderness - the latter actually being a deviant kind of spirituality compared with the garden. Second, the frame serves as a gateway through which the devotional purpose of interiorisation can be realised more efficiently. ${ }^{41}$ It makes the implosion of energy bearable. It soothes the appearance of the horror vacui of the Enclosed Garden. The element of scopophilia is retained in a streamlined cocoon; it is tamed by the frame. To borrow a term from Aby Warburg, one could say that the frame restrains the aspect of nomadische Bildlichkeit ('wandering imageries'); the frame fixes the gaze on the interior. (The opposite would be unbearable in the context of a horror vacui, where things would otherwise 'fall apart', and the centre would be 'unable to hold', to quote Yeats. ( $^{42}$ Third, in the case of Enclosed Gardens, the frame is not just a frame. In fact, an Enclosed Garden is more like a 'room', so that the frame is more of a box than a frame. And finally, the room can even be closed when not needed.

So might these Enclosed Gardens - on the basis of their content of curiosities and relics, their treasuring of precious pearls, their function as a homelike shelter, their techniques of binding, knotting, sewing, gluing together, and finally the psycho-energetic and physical contamination with the makers' body - not just as easily be referred to as 'nests'? ${ }^{43}$ The word 'nest' is etymologically related to the notion of an Enclosed Garden 
through 'niche'. The French niche is most likely derived from the verb nicher 'to build a nest', which in turn comes from Latin nidicare or nidificare, from nidus (nest). ${ }^{44}$ Hence, the spatial connotation of niche emerged through formal similarities with the most intimate shell around something extraordinarily precious and fragile.

Gaston Bachelard (1884-1962) writes in his The Poetics of Space about the nest:

The philosophical phenomenology of nests is being able to elucidate the interest with which we look through an album containing reproductions of nests or even more positively, in our capacity to recapture the naïve wonder we used to feel when we found a nest. This wonder is lasting, and today when we discover a nest it takes us back to our childhood or, rather, to a childhood; to the childhoods we should have had. For not many of us have been endowed by life with the full measure of its cosmic implications. ${ }^{45}$

The dialects between forest love and love in a city room is between wilderness and a nest, yes, between nature and the Enclosed Garden. A nest is never young; we come back, it is the sign of return and of daydreams. ${ }^{46}$

'Technical' features of the nest also bring us close to the Enclosed Gardens, as we learn from Jules Michelet's (1798-1874) observations on birds and their special skills and tools they handled for the making of their nest. According to Michelet: 'a bird is a worker without tools. In reality a bird's tool is its own body, that is, its breast, with which it presses and tightens its materials until they have become absolutely pliant, well-blended and adapted to the general plan. ${ }^{97}$ A house built by and for the body taking form from the inside, like a shell, is an intimacy that works physically. 'The form of the nest is commanded by the inside. On the inside the instrument that prescribes a circular form for the nest is nothing else but the body of the bird. It is by constantly turning round and round and pressing back the walls on every side that it succeeds in forming this circle. ${ }^{4} 8$

Bachelard adds that 'the female, like a living tower, hollows out the house, while the male brings back from the outside all kinds of materials, sturdy twigs and other bits. By exercising an active pressure, the female makes this into a felt-like padding. ${ }^{29}$

The house is a bird's very person; it is its form and its most immediate effort, I shall even say, its suffering. The result is only obtained by constantly repeated pressure of the breast. There is not one of these blades of grass that, in order to make it curve and hold the curve, has not been pressed on countless times by the bird's breast, its heart, surely with difficulty in breathing, perhaps even with palpitations. ${ }^{50}$

Why is it worse for us to say that an angle is cold and a curve warm? That the curve welcomes us and the over-sharp angle rejects us? That the angle is masculine and the curve feminine? A modicum of quality changes everything. The grace of a curve is an invitation to remain. We cannot break away from it without hoping to return. For the beloved curve has nest-like powers; it incites us to possession, it is a curved 'corner', inhabited geometry. Here we have attained a minimum of refuge, in the highly simplified pattern of a daydream of repose. But only the dreamer who curls up in contemplation of loops understands these simple joys of delineated repose. ${ }^{51}$ 
The nest is a swelling fruit, pressing against it limits. It is an expression of praise of its felt-like fabric. ${ }^{52}$ All this is the Enclosed Garden!

That is why the ultimate epistemology of Enclosed Gardens is the 'state of expectation' and the slow action of hands that are wrapping, sewing, buttoning: the manuductus that takes over the choreography of the waiting and incorporates it. It testifies to a long tradition of work that does not focus much on the invention of new designs and topics but more on the growth of things by craft, thus resembling the creational spirit in nature. The textile craft of the Besloten Hofjes thus does not merely produce a passive container for divine power but actively binds it up.

\section{Notes}

1 The Enclosed Gardens of the Mechelen Hospital Sisters are the focus of an ongoing interdisciplinary project (2014-18), which will result in their presentation at the In Search of Utopia exhibition at M Museum in Leuven in 2016 and then in permanent display in the Museum Hof van Busleyden in Mechelen from 2018. See also: 'The Enclosed Gardens of the Municipal Museums of Mechelen', last modified on 2 March 2015, http://www.illuminare. be/enclosed-gardens-municipal-museums-mechelen\#overlay-context=projects- 0 .

2 Simone Scholten, 'Besloten hofjes des 16. Jahrhunderts in Mechelen' (unpublished PhD thesis, University of Bonn, 1996); Heidi De Nijn et al., 800 jaar Onze-Lieve-Vrouwegasthuis. Uit het erfgoed van de Mechelse gasthuiszusters en het OCMW, exhib. cat. (Mechelen: Drukkerij Buroform, 1998); Monika Triest, Het besloten hof. Begijnen in de zuidelijke Nederlanden (Leuven: Van Halewyck, 2000); Michael Wolfson, Ein Rundgang durch Kloster Ebstorf (Königstein im Taunus: Langewiesche, 2001), 64-5, no. 392.1.

3 On the sculpting component in particular, see Marjolijn Kruip, 'In beeld gebracht. De sculptuur in laatmiddeleeuwse Besloten Hofjes' (unpublished MA thesis, University of Nijmegen, 2006).

4 See also: Barbara Baert, "Echoes of Liminal Spaces. Revisiting the Late Mediaeval "Enclosed Gardens" of the Low Countries. (A Hermeneutical Contribution to Chthonic Artistic Expression)', in Paul Vandenbroeck (ed.), Antwerp Royal Museum Annual (2012; appeared in 2014/15), 9-45; Barbara Baert, 'Instrumentalities and the Late Medieval "Enclosed Gardens" in the Low Countries', Kunst og Kultur 3 (2016), 131-41; Barbara Baert (with the collaboration of Hannah Iterbeke), 'Revisiting the Enclosed Gardens of the Low Countries (Fifteenth Century Onwards). Gender, Textile, and the Intimate Space as Horticulture', Textile: Cloth and Culture 14 (2016), 1-30; Barbara Baert, 'Die spätmittelalterlichen eingefassten Gärten in den Niederlanden', Zeitschrift für Medien- und Kulturforschung 7 (1) (2016), 27-44.

5 Miri Rubin, Corpus Christi: The Eucharist in Late Medieval Culture (Cambridge: Cambridge University Press, 1991); Paul Vandenbroeck, Le jardin, clos de l'âme. L'imaginaire des religieuses dans les Pays-Bas du Sud, depuis le 13e siècle (Brussels: Société des Expositions Palais des Beaux-Arts de Bruxelles, 1994); Jeffrey F. Hamburger, Nuns as Artists: The Visual Culture of a Medieval Convent (Berkeley, CA: University of California Press, 1997); Jeffrey F. Hamburger, 'Body vs. book: the trope of visibility in images of Christian-Jewish polemic', in David Ganz and Thomas Lentes (eds), Ästhetik des Unsichtbaren. Bildtheorie und Bildgebrauch in der Vormoderne (Berlin: Reimer, 2004), 113-45; Jeffrey F. Hamburger and Robert Suckale, 'Zwischen Diesseits und Jenseits. Die Kunst der geistlichen Frauen im Mittelalter', in Jeffrey F. Hamburger and Marti Susan (eds), Krone und Schleier. Kunst aus mittelalterlichen Frauenklöstern, exhib. cat. (Munich: Hirmer, 2005), 21-39. See also: JeanClaude Schmitt (ed.), Femmes, art et religion au Moyen Âge (Strasbourg-Colmar: University Press of Strasbourg-Museum d'Unterlinden, 2004).

6 For some nuanced points of view within the methodologically rigorous division between so-called profane and sacred spaces, see: Diana Webb, 'Domestic Space and Devotion in the Middle Ages', in Andrew Spicer and Sarah Hamilton (eds), Defining the Holy. Sacred Space in Medieval and Early Modern Europe (Aldershot: Ashgate, 2008), 27-48.

7 On the ambiguous typology of Enclosed Gardens within the phenomenon of the relic, the curiosity, the fetish and, by extension, research into what is a 'remnant' and what is an 
'object', see: Stefan Laube, Von der Reliquie zum Ding. Heiliger Ort - Wunderkammer Museum (Berlin: Akademie-Verlag, 2011), 31: 'Fragen drängen sich auf: Galten die Objekte als sakral oder eher als profan? Durfte das kuriose oder fremde Objekt ausgefallen bleiben, oder wurden darauf biblische oder dogmatische Bedeutungen projiziert?' See also: Tristan Weddigen, 'Resteverwertung', Kritische Berichte (Rest, Fetisch, Reliquie) 336 (2008), 3-6, at 6: 'Der Kunstwisschenschaft zu bedenken gibt, ob sie nicht ebenfalls an der Veredlung von Resten zu Fetischen und Reliquien beteiligt ist'; Allison Stielau, 'The case of the case for early modern objects and images', Kritische Berichte (Die Kunst und die Dinge. Perspektiven einer schwierigen Beziehung) 39 (3) (2011), 5-16, at 5: 'As an object meant to embrace another object, the etui sits in an undefined interstice between received categories. It is not comfortably a work of art. Nor, when ornamented and carefully crafted, can it be placed in the vast category of functional objects known as "material culture"'; Kathryn M. Rudy, Postcards on Parchement: The Social Lives of Medieval Books (New Haven, CT: Yale University Press, 2015), 23-9, 217-19, 235-6.

8 Wolfgang Stammler, 'Der allegorische Garten', in Wolfgang Stammler (ed.), Wort und Bild. Studien zu den Wechselbeziehungen zwischen Schrifttum und Bildkunst in Mittelalter (Berlin: Schmidt, 1962), 106-16.

9 The ensembles of statuettes in Enclosed Gardens are reminiscent of the monumental Golgotha and/or Holy Sepulchre copies that one sometimes encounters in monasteries and beguinages.

10 Felix B. A. Asiedu, 'The Song of Songs and the Ascent of the Soul: Ambrose, Augustine, and the Language of Mysticism', Vigiliae Christianae 55 (3) (2001), 299-317.

11 Ann W. Astell, The Song of Songs in the Middle Ages (Ithaca, NY: Cornell University Press, 1990); 'Le cantique des cantiques', Graphé 8 (Arras: University Press of Lille, 2005); Ann Matter, The Voice of My Beloved. The Song of Songs in Western Medieval Christianity (Philadelphia, PA: University of Pennsylvania Press, 1992).

12 Alain Michel (ed.), Théologiens et mystiques au Moyen Âge (Paris: Gallimard, 1997), 247.

13 On the semiotics of the Song of Songs and the spirituality of love and eroticism: Patricia C. Miller, 'Pleasure of the text, text of pleasure. Eros and language in Origen's commentary on the Song of Songs', Journal of the American Academy of Religion 54 (2) (1986), 241-53.

14 Jeffrey F. Hamburger, The Rothschild Canticles: Art and Mysticism in Flanders and the Rhineland circa 1300 (New Haven, CT: Yale University, 1990).

15 Reindert L. Falkenburg, 'The household of the soul. Conformity in the Mérode Triptych', in, Maryan Ainsworth (ed.), Early Netherlandish Painting at the Crossroads. A Critical Look at Current Methodologies (New York and New Haven, CT: Metropolitan Museum of Art/ Yale University Press, 2001), 2-17; Emanuel S. Klinkenberg, “'Wil diin herte bereeden gheliic eenen huze.” De binnenhuisallegorie in de geestelijke letterkunde', Queeste. Tijdschrift over middeleeuwse letterkunde 14 (2) (2007), 126-53.

16 Guido Hendrix (ed.) Hugo de Santo Caro's traktaat 'De doctrina cordis', vol. 2 (Leuven: University of Leuven, 1995), 14.

17 The sermon is known from a Dutch manuscript of the fifteenth century: wi die floeren end die wanden mede vercieren sullen als mit welrukende bloemen (Leiden: University Library), Ltk 2189, fol. 198v.

18 Kathryn M. Rudy, Virtual Pilgrimages in the Convent. Imagining Jerusalem in the Late Middle Ages (Turnhout: Brepols, 2011), 110-18.

19 Ibid., 114.

20 See also: Rozsika Parker, The Subversive Stitch. Embroidery and the Making of the Feminine (London: Tauris, 1989).

21 Ellen Harlizius-Klück, Weberei als episteme und die Genese der deduktiven Mathematik (Berlin: Edition Ebersbach, 2004). This challenging study starts from Greek semantic roots analysing the linguistic idiom surrounding weaving. The author finds traces of the origins of mathematics as a cosmological model.

22 Camille Poupeye, 'Les Jardins clos et leurs rapports avec la Sculpture malinoise', Bulletin du Cercle archéologique, littéraire et artistique de Malines (1912), 51-114; Erik Vandamme, 'Het "besloten hofje" in het Koninklijk Museum voor Schone Kunsten te Antwerpen. Bijdrage tot de studie van de kunstnijverheid in de provinciale Zuidnederlandse centra omstreeks 1500', in Maurits Smeyers et al. (eds), Archivum Artis Lovaniense. Bijdragen tot de geschiedenis 
van de kunst der Nederlanden, opgedragen aan Prof. Em. Dr. J. K. Steppe (Leuven: Peeters, 1981), 143-9; Julia Kristeva,'Het Geluk der Begijnen', in Paul Vandenbroeck (ed.), Hooglied: De Beeldwereld van Religieuze Vrouwen in de Zuidelijke Nederlanden, vanaf de 13de eeuw, exhib. cat. (Ghent: Snoeck-Ducaju \& Zoon, 1994), 177; De Nijn, 800 jaar Onze-LieveVrouwegasthuis. Uit het erfgoed van de Mechelse gasthuiszusters en het OCMW, 49-57.

23 This section is a summary of an unpublished MA thesis and is inspired by Barbara Baert's research on the Enclosed Gardens. See: Barbara Baert, Late Medieval 'Enclosed Gardens' of the Low Countries: Contributions to Gender and Artistic Expression, Studies in Iconology 2 (Leuven: Peeters, 2016); Baert, 'Echoes of liminal spaces', 9-45; Hannah Iterbeke, 'Devotie tot de zijden bloem: tussen techniek en betekenis, de zijden bloemen uit de Besloten Hofjes van de Lage Landen in de zestiende eeuw' (unpublished MA thesis, University of Leuven, 2015).

24 Bruno Schier, 'Die Kunstblume von der Antike bis zur Gegenwart', Veröffentlichungen des Instituts für Deutsche Volkskunde 11 (Berlin: Akademie-Verlag, 1957), 1-15.

25 Similar arguments were also presented by Thione Rath, Horst Apphun and Manfred Schober who came to the same conclusions. These authors based their assumptions on the results of each other's studies, which prevented them from shedding new light on the origins and devotional functions of the silk flowers. Horst Apphun, 'Die Paradiesgartlein des Klosters Ebstorf: Der hochwürdigen Frau Äbtissin Edelgard von Arnswaldt Gewidmet', Lünebruger Blätter 19/20 (1968/9), 36; Tione Rath, Der geschichte der Seidenblume (Hannover: Schaper Verlag, 1981), 7-8; Manfred Schober, Die Sebnitzer Kunstblume: Die Geschichte eines Handwerks im Zeichen der Mode Dresden (Dresden: Verlag der Kunst Dresden, 1994).

26 On statues see: Kruip, 'In beeld gebracht: de sculptuur in laatmiddeleeuwse Besloten Hofjes'; Casteleyn Lothar and Jos Koldeweij, 'Geloof en Geluk Onderweg', Openbaar Kunstbezit Vlaanderen 44 (2006), 1-29.

27 The document follows: 'Item, pour les vacquacions qu'il a mis autour de la façon du jardinet que madicte dame a fait faire audict Gand de fleurs de soye et aultres menutez, en quoy avec les religieuses de Guallilée il a vaequé xx jours entiers, qui, au pris de viij sous ung chascun jour,' Alexandre Pinchart, Archives des arts, sciences et lettres. Documents inédits publiés et annotés par Alexandre Pinchart, vol. 1 (Ghent: Hebbelynck, 1860-81), 17. See also: Monique Lenaerts, 'Margareta van Oostenrijk en de kunst (1480-1530): Bijdrage tot de studie van het mecenaat in de Zuidelijke Nederlanden tijdens de eerste decennia van de zestiende eeuw' (unpublished MA thesis, University of Leuven, 1984); Dagmar Eichberger, Leben mit Kunst, Wirken durch Kunst: Sammelwesen und Hofkunst unter Margarete von Österreich, Regentin der Niederlande (Turnhout: Brepols, 2002), 395-9.

28 Gerardus Domenicus Azevedo mentions in his chronicle an imposition of 1520-5 which states the following: '. . . Uyt de selve Impositie blyckt oock, dat de Religieusen der Vrouwe Cloosters van Betanien, Thabor, Blyenberge, Leliendael ende Muysene, Lyne laeckens oft lynwaerten verkochten oft penneweerden, de welcke sy oock waerschynelijck selfs maeckten, ende de Overdracht van het gene sy verkochten, deden aen hunnen Rent-meester ofte Voorganger van't Clooster, elck in't sijne: als oock de Beggynen, de welcke alsdan meest alle Lyne-laeckenen oste Lynwaerten maeckten, moesten van alles dat sy daer van verkochten overleren aen eenige van hunne Groote-meesteressen ..... Gerardus Dominicus de Azevedo, Korte Chronycke van vele gedenckweerdige geschiedenissen soo in de principaele steden van het hertogdom Brabant als in de Stad ende Provincie van Mechelen (Leuven: Joannes Jacobs, 1747), 96-7. On beguines and silk workers, see: Stabler Miller, The Beguines of Medieval Paris: Gender, Patronage and Spiritual Authority (Philadelphia, PA: University of Pennsylvania Press, 2014), 173-4.

29 This painting is part of the same collection as the Enclosed Gardens although it originally belonged to the beguinage of Mechelen. L. J. M. Philippen, 'Begijnen-werkzaamheden naar een schilderij in 't Mechelsch Begijnhof', in Prosper Verheyden gehuldigd ter gelegenheid van zijn zeventigsten verjaardag 23 october 1943 (Antwerp: Nederlandsche boekhandel, 1943), 52.

30 In Dutch: 'Suster sijdy besich roosenhoeden te maeken, aerbeyt om totten maechden croon te geraeken'.

31 Anonymous, Den gheestelijcken boomgaert der vruchte daer die devote siele haer vadict van de vruchte ter passien [Christi] (Antwerp: Willem Vorsterman, s.d.); Pierre D'Ailly, Thoofkijn van devotien (Antwerp: Gerard Leeu, 1487). On these books see also: Barbara Baert, Een erfenis van heilig hout: De neerslag van het teruggevonden kruis in tekst en beeld 
tijdens de Middeleeuwen (Leuven: Universitaire Pers Leuven, 2001), 254; Barbara Baert, Late Medieval 'Enclosed Gardens' of the Low Countries: Contributions to Gender and Artistic Expression, 15-16. On the imagery of flower crowns see also: Wolfgang Stammler, 'Studien zur Geschichte der Mystik in Norddeutschland', in Kurt Ruh (ed.), Altdeutsche und Altniederländische Mystik (Darmstadt: Wissenschaftliche Buchgesellschaft, 1964), 410-14; Anne Winston-Allen, Stories of the Roses: The Making of the Rosary in the Middle Ages (University Park, PA: Pennsylvania State University Press, 1988), 81-111; Barbara Newman, 'Speculum Virginum: elected Excerpts', in Constant J. Mews (ed.), Listen, Daughter: The Speculum Virginum and the Formation of Religious Women in the Middle Ages (New York: Palgrave, 2001), 269-97; Rabia Gregory, 'Marrying Jesus: Brides and the Bridegroom in Medieval Women's Religious Literature' (unpublished PhD thesis, University of North Carolina, 2007), 43-85.

32 ... metter rooder roozen va(n) lichameliker en vleeschliker maechdelijcheyt en metter witter roozen de gheestelijker suverheyt en netheyt . . . die haren lieve alsulcke cransken maken ende presentere mach ende met alsulcke bloemkens omsetten. Dit es het present dat hi van synen vriendinne eyscht en beghert. Pierre D'Ailly, Thoofkijn van devotien.

33 Ellen Harlizius-Klück, 'Postscript', in Baert, Late Medieval 'Enclosed Gardens' of the Low Countries, 77-84.

34 In Christian iconography, the white lily represents the virginity and purity of the Blessed Virgin. The image is derived from a verse of the Song of Songs 'Sicut lilium inter spinas, sic amica mea inter filias'. On the sinner-saint Mary Magdalene see: Barbara Baert, To Touch with the Gaze: Noli me tangere and the Iconic Space (Oostakker: Sint Joris, 2011).

35 Barbara Baert, “An Odour. A Taste. A Touch. Impossible to Describe”: Noli me tangere and the Senses', in Wietse De Boer and Christine Göttler (eds), Religion and the Senses in Early Modern Europe (Leiden: Brill, 2013), 142-5.

36 Joke Vandermeersch, Lieve Watteeuw et al., 'De conservering van de 16de-eeuwse Mechelse Besloten Hofjes. Een interdisciplinaire aanpak voor historische mixed media', 8th BRKAPROA Colloquium, Innovatie in de Conservatie-Restauratie, Brussel, 12-13 November 2015 (2016), 41-52. Experience gained during the conservation of the Bentlager Reliquiëngärten and the Enclosed Garden in the Nicolai Kirche in Kalkar were of great inspiration for the conservation team in Mechelen. See: Arnulf Von Ulmann, 'Die Restaurierung der Bentlager Reliquiëngärten. Die Untersuchung', Westfalen. Hefte für Geschichte, Kunst und Volkskunde 77 (I) (1999), 114-36; Stephan Brunnert, Gudrun Hildebrandt, Richard Moroz, Annik Pietsch and Frauke Wenzel, 'Die Restaurierung der Reliquiëngärten aus Kloster Bentlage', Westfalen: Hefte für Geschichte Kunst und Volkskunde 77 (I) (1999), 137-73; Reinhard Karrenbrock and Marc Peez, 'Die "besloten hofjes" in St. Nicolai in Kalkar', in Jabrbuch der rheinischen Denkmalpflege 44 (I) (Worms: Wernersche Verlagsgesellschaft, 2014), 118-46; Martin Hammer and Gisela Hauck, "Ein "besloten hofje" aus dem Johannesaltar in St. Nicolai in Kalkar', in Jahrbuch der rheinischen Denkmalpflege, 44 (I) (Worms: Wernersche Verlagsgesellschaft, 2014), 147-72.

37 The bottom base is made of blocks of pressed peat or turf (partially decayed vegetation and organic matter) loosely covered with green silk. The back and the ceiling consist of a primary very thin oak wood panel, which is separate from the robust Baltic oak retable box.

38 The composition and attachment of the flowers and artefacts was probably done when the wooden box lay horizontally (observation of the conservation team, 2015).

39 The 'O. L. Vrouwegasthuis aan de Dijle' moved to the Keizestraat in 1857 and to a complex near the Augustijnenstraat and the Bleekstraat in 1956, taking with them their seven Enclosed Gardens. See: De Nijn, 800 jaar Onze-Lieve-Vrouwegasthuis, 49-57.

40 Mechelen, Enclosed Garden Project (2014-16), Project Archive. From 2012 to 2014, detailed condition reports were made by the eight conservators-restorers with visual and technical documentation, defining the position, the composition and the condition of each element in the retable box. Each artefact has a reference number. Files, images and analysis are managed in a data platform by KU Leuven, Faculty of Arts, Illuminare. The results were presented on 10 January 2017 during the Twentieth Symposium for the Study of Underdrawing and Technology in Painting, 'Imaging Utopia: New Perspectives on Northern Renaissance Art'. A monograph about the interdisciplinary research on the Mechelen Enclosed Gardens is planned for March 2018, when the seven Enclosed Gardens will be on display in the renovated Museum Hof van Busleyden (Mechelen). 
41 Jose Ortega y Gasset, 'Meditations on the frame', Perspecta (Theater, Theatricality, and Architecture) 26 (1990), 185-90.

42 After William Butler Yeats (1865-1939) in his The Second Coming, 1919.

43 Tim Ingold, Lines. A Brief History (London and New York: Routledge, 2007), 85.

44 'Nis (Holle Ruimte)', last modified 2010, http://www.etymologiebank.nl/trefwoord/nis1.

45 Gaston Bachelard, The Poetics of Space, trans. Maria Jolas et al. (New York: Penguin, 2014), 114.

46 Ibid., 119.

47 Jules Michelet, L'oisean (Paris: Hachette, 1858), 208. See also: Joseph Joubert, Pensées de J. Joubert, vol. 2 (Paris: Bloud, 1909), 167: 'It would be interesting to find out if the forms that birds give their nests, without ever having seen a nest, have not some analogy with their own inner constitutions.'

48 Michelet, L'oiseau, 208.

49 Bachelard, The Poetics of Space, 121.

50 Michelet, L'oiseau, 208.

51 Bachelard, The Poetics of Space, 165.

52 Ibid., 122. 

Part 2

The Power of Things 



\title{
3 Knighted by the Apostle Himself Political Fabrication and Chivalric Artefact in Compostela, 1332
}

\author{
Rosa M. Rodríguez Porto
}

On the morning of the feast of St James in 1332, at a time when the star of the shrine of St James seemed to wane, the interior of the Romanesque cathedral of Santiago de Compostela was turned into a stage for one of the most exceptional rituals ever performed in Iberia - or anywhere else: King Alfonso XI of Castile's knighting ceremony by the Apostle himself. ${ }^{1}$ Documentary records some months before attest to the sovereign's decision to organise his knighting ceremony, since he had asked for a special tribute from some of the cities of his kingdom in order to cover the expenses of the festivities. ${ }^{2} \mathrm{He}$ had also sent some assistants to purchase luxurious textiles and swords in Avignon to enhance this display of royal grandeur. ${ }^{3}$ Yet, except for the Compostelan canons and those belonging to the closest entourage of the monarch, it would have been hard to ascertain what was going to happen.

The chronicle of his reign - written around ten years later than the events described leaves the historian amazed and frustrated, unable to come to terms with the ceremony described. It is retold there how the king had spent the night in vigil, with his armour on the altar. At dawn on 25 July the archbishop said mass and blessed the weapons with which King Alfonso proceeded to arm himself in full plate armour. Then he girded himself with his sword 'so he should receive them from no other' and approached the statue (imagen) of Saint James that was above the altar until he was close enough to make it strike him on the cheek. And 'this was this manner in which the King received knighthood from the Apostle Saint James'. ${ }^{4}$

It would be possible to raise doubts about the historicity of the whole story were it not for the fact that the striking imagen de Sanctiago mentioned in the text is still preserved in the royal monastery of Las Huelgas de Burgos, where it has been kept for almost seven centuries (Figures 3.1 and 3.2)..$^{5}$ Erroneously considered by some modern scholars as the 'knighting device' used by all Castilian kings according to a fanciful historiographic tradition going back no earlier than the beginning of the eighteenth century, this remarkable work went unnoticed until recent times. ${ }^{6}$ Peter Linehan deserves credit for having called attention to the unusual nature of the Compostelan solemnities and masterfully disclosing the political implications of this artefact, which should be regarded as a calculated response to the problem posed by the death of King Fernando IV in 1312 when Alfonso XI was still a little child: since his father had not been able to give him the accolade, how could the young monarch be knighted without compromising his royal authority in relation to his surrogate padrino (godfather) and, above all, without remaining bound to him by feudal homage?? 


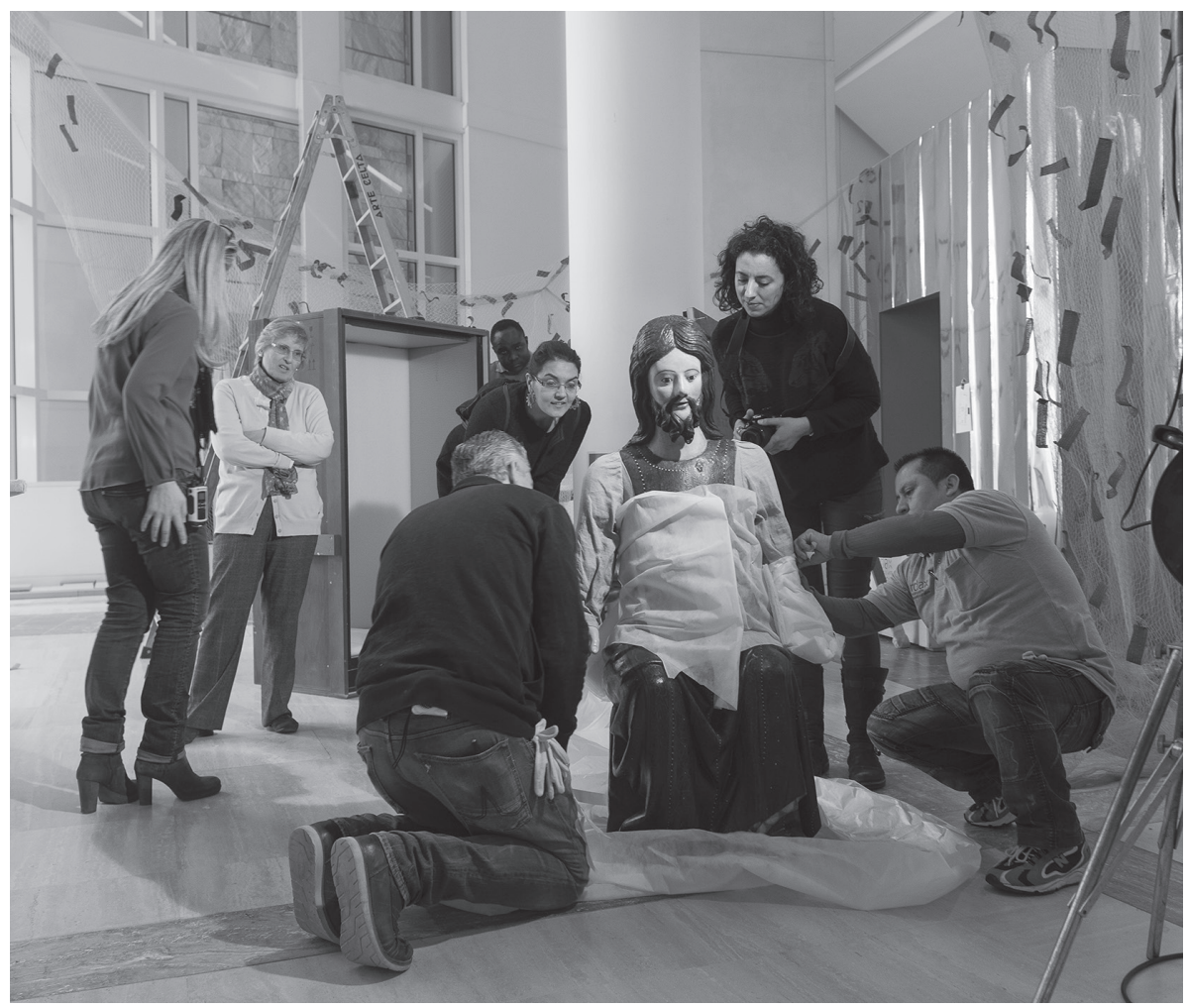

Figure 3.1 The statue of Santiago del Espaldarazo is arranged for display in the exhibition Santiago: A orixe. Santiago de Compostela, Cidade da Cultura.

For a king about to undertake what would prove the definitive military campaign on the Strait of Gibraltar and to mobilise the imagery of chivalry as a cohesive social force after decades of political instability, that was not a minor issue. ${ }^{8}$ However, the idea of dubbing himself - as the emperor Alfonso VII had done in the Galician basilica in 1124 or as King Pedro IV, el Ceremoniós, will later do at Zaragoza in 1336 was out of question. Those subterfuges had been dismissed by his great-grandfather Alfonso X, the Learned King, who had stated in his Siete Partidas (c. to 1256-65) that it was mandatory to find another agent capable of conferring that dignity on the king. ${ }^{9}$ Hence the crucial role, albeit brief and limited to the blow on the cheek, played by $\mathrm{St}$ James by means of his imagen at Compostela.

For sure, none would have disputed the apostle's credentials as a warrior or his rule over chivalric matters. However, in order to wholly understand what was at stake for the Castilian king, more should be said about the other ceremonies that followed in Burgos that summer of 1332. There were other reasons indeed that accounted for the anxiety of Alfonso XI to have an impeccable knighting ceremony. The authority of King Sancho IV - Alfonso X's second son and disinherited by him - and his descendants, Alfonso XI among them, had been under dispute ever since the death of the Learned King in 1284. After having recognised their rights in Alfonso X's last will, the sons of the 


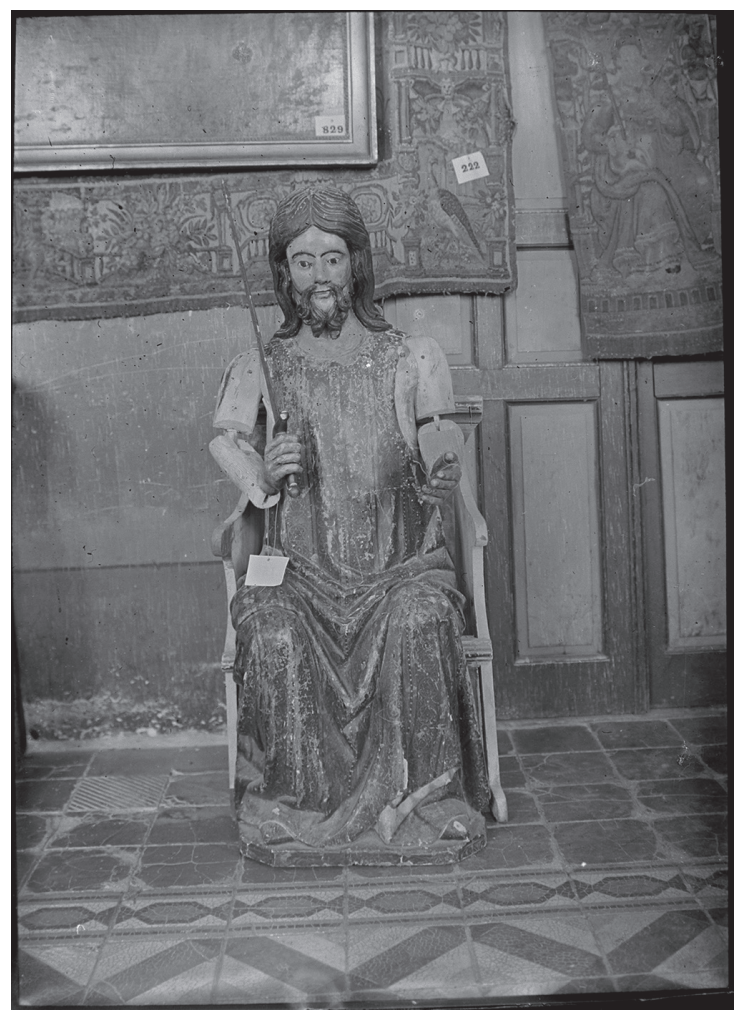

Figure 3.2 Santiago del Espaldarazo. Monasterio de Las Huelgas de Burgos.

deceased infante Fernando de la Cerda had been pursuing their claims to the Castilian throne for decades. So it was not unreasonable for Alfonso XI to consider the possibility of being formally crowned some years after his coming of age in 1325, in the hope of adding a surplus of 'royal mystique' to his not yet fully established figure. ${ }^{10}$

It should be noted that Iberian kings - and particularly Castilian kings - were not crowned but proclaimed by the highest ranks of the nobility after the death of their predecessors. ${ }^{11}$ Since, therefore, coronation was not common practice for Castilian kings, it was necessary to produce a proper Coronation Book (Escorial, MS \&.III.3; c. 1328-31) wherein the diverse steps of the ritual were analysed in detail and accompanied by explanatory miniatures. ${ }^{12}$ As one of the oldest coronation books preserved and only comparable to the ordo made for Louis IX around 1250 (Paris, Bibliothèque nationale de France, ms. lat. 1246), Escorial, MS \&.III.3 was remarkable in more senses than one. ${ }^{13}$

Yet, as Peter Linehan has pointed out, the Libro de la Coronación was left unfinished because it felt short of the king's ambitions. ${ }^{14}$ In fact, analysis of the text of the Crónica de Alfonso XI reveals that several changes were introduced in the order of these ceremonies in 1332, beginning with the separation and relocation of anointing and coronation. Instead of taking place in Santiago de Compostela as prescribed by 
the ordo, both rituals were performed at the Cistercian abbey of Las Huelgas, the very same place where Fernando de la Cerda had been buried. Other aspects, though, must have been defined after a careful scrutiny of the coronation of Alfonso IV of Aragón in 1328. ${ }^{15}$ On that occasion, the Aragonese king had crowned himself, an act of obvious significance that was replicated by Alfonso XI in Las Huelgas despite the fact that the Libro de la Coronación would have presumably prescribed a more orthodox imposition of the crown by the archbishop of Santiago. ${ }^{16}$ But, even if the Castilian king claimed his part in the interaction of regnum and sacerdotium as eagerly as his Aragonese counterpart, the definition of the remaining rituals was subtler in Burgos, not least because Alfonso XI had been proclaimed king of Castile more than twenty years before and had been acting on his own since 1327 . In contrast to Alfonso IV - who had experienced these rituals shortly after his father's death - neither the anointing nor the coronation was meant to change the status of the Castilian king.

As a result, the girding became the pivotal element in the Compostelan solemnities since it was the only actual rite of passage the king was to go through. In fact, the traditio gladii was loaded with meaning for Iberian kings due to the prominence of the sword among the regalia: for the 'reconquering' Iberian kings, it was deemed more important for defining the power and authority of the monarch than the crown itself. ${ }^{17}$ Well aware of the consideration of kings first and foremost as conquering warriors, the author of the ordo - Bishop Raymond II Ebrard of Coimbra - had prescribed that the king was to take the sword from the altar himself. Nonetheless, the problem posed by the homage to the padrino remained until, in a stroke of genius, the arrangement of a ceremonial knighting by effigy was introduced for the sophisticated articulation of the ritual's different elements. In doing so, Alfonso XI was also able to avoid any kind of ecclesiastical interference in an act that was deemed crucial for defining royal authority. On the other hand, the substitution of the ecclesiastical liturgy by a strictly secular or para-liturgical formulation of the knighting ceremony - with the pescozada (blow on the cheek) as the key element rather than the handing over of the sword by the bishop - would also have imprinted a more martial and lay tone on these solemnities, in accordance with the chivalric ethos that the king was trying to promote with the creation of the Orden de la Banda (Order of the Sash). ${ }^{18}$ Last but not least, by creating a personal bond with the apostle, the king would have placed himself above Castilian society and, most specifically, at the apex of a knightly and aristocratic elite. As a result, this gesture would have contributed as well to the taming of the rebellious nobility after decades of internecine struggles, since many young members of the most renowned aristocratic lineages were to be subsequently knighted by the king in Burgos, and the bond then created would last until the end of Alfonso's reign. ${ }^{19}$

However, the use of an articulated statue of the Apostle Saint James would have also evoked a constellation of disparate images in the minds of the viewers, bringing with them unexpected connotations and further problematising the perception of the knighting ceremony. Although I am persuaded of the plausibility of the precise political interpretation I have tried to elucidate so far, as well of the careful re-elaboration of contemporary coronation ordines and recent solemnities attested by the Libro de la Coronación and the Crónica de Alfonso XI, I cannot but hesitate when it comes to assessing how this unusual ritual would have actually been regarded by the variegated audience gathered at Santiago. For that reason, in what remains of this article I would like to explore other possibilities in a sort of critical 'deconstruction' - the use of the term is not unwarranted in this context - of my previous research on the 1332 events. 
I have tried to organise my observations along the three main divides mediated by the imagen de Sanctiago: image/object, effigy/icon and univocity/entropy. While the first of them alludes to the tensions present at the core of the statue itself, as a material artefact representing a saintly prototype in a particular holy environment, the second delves into the analysis of the status of the articulated figure, which occupied an ambiguous territory in between the legal and religious spheres. For its part, the third section offers some closing remarks about the intelligibility of the whole ceremony, trying to disclose the effect provoked by those bewildering and contradictory features on the viewers.

\section{Image/Object}

The renewed emphasis on materiality has forced scholars to deal with works that, like the Santiago del Espaldarazo can hardly be regarded as a 'disembodied image'. ${ }^{20}$ Quite to the contrary, this very corporeal figure seems to convey the presence of its saintly referent, even if the attention paid to its very physicality brought about striking revelations when the sculpture was restored in 1993. According to Francisco Torrón, who was in charge of the procedure, the statue originally had been that of a Virgin with the Child later adapted to its new dedication by means of the addition of a beard, the recarving of the breast and hip areas, and the modification of the right hand holding the sword. ${ }^{21}$ 'Gender-crossing' suggests that the decision to enrol the apostle St James as padrino was not part of the original conception of the ceremony and that the imagen must have been adapted shortly before the event took place. ${ }^{22}$

Besides, a second consideration presents itself when thinking about the role of the statue in the Compostelan ritual and, more specifically, about its agency as 'thing'. ${ }^{23}$ As can be observed in photographs taken prior the restoration (Figure 3.2), the statue's arms are articulated with mobile joints at both shoulders and elbows, although there is no mechanism allowing an independent movement of the limbs. This feature distinguishes the Santiago del Espaldarazo from automata such as the famous Virgen de los Reyes in Seville and helps to make sense of the strange phrasing used in the Crónica de Alfonso XI to describe the pescozada. ${ }^{24}$ When read carefully, the chronicle gives the impression that it was not the Apostle who dubbed the king, but Alfonso himself who came next to the altar and 'made the statue strike him on the cheek', to the point of blurring - and almost reversing - the distinction between active and passive roles. ${ }^{25}$

Nevertheless, in order to understand the precise nature of the interaction between king and statue, it would be necessary to begin by characterising the placement of the Santiago del Espaldarazo at the core of the liturgical space of the cathedral. Although the Baroque reforms have substantially altered the appearance of the main altar, late medieval depictions of the cathedral of Santiago such as those preserved in the Cartulary of the Hospital of St Jacques in Tournai (Tournai, Bibliothèque de la Ville, MS 27, fol. 1r; Figure 3.3) or the Flemish Altarpiece in the Indianapolis Museum of Art attributed to the Master of the Legend of St Godelieve (c.1500), allow us suppose that many elements of the original Romanesque shrine would still have been in place in 1332. As in earlier times, the remains of the ancient apostolic mausoleum would have been kept hidden behind the altar (c.1105-6) and the retable (c.1137) commissioned by Archbishop Gelmírez - both in gilded silver - concealing the relics of the Apostle from pilgrims who normally would also have seen their access to the altar blocked by the high iron rood screen. ${ }^{26}$ They could only have gained admission to the confessio, 


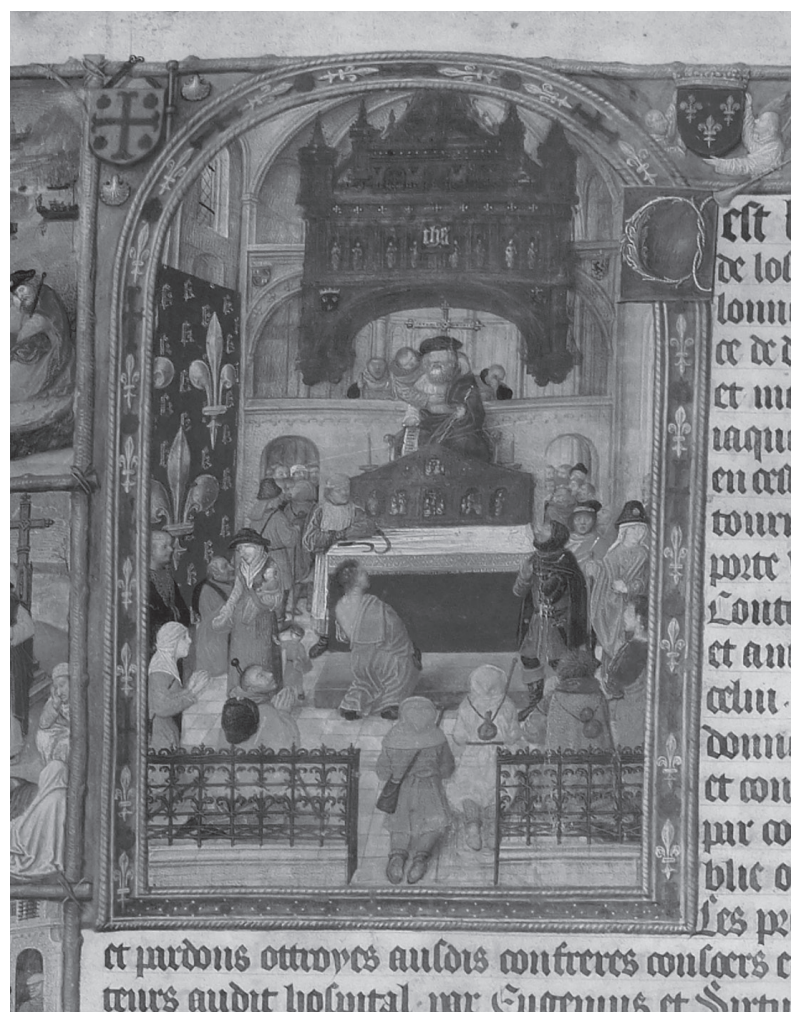

Figure 3.3 Cartulary of the Hospital of St Jacques of Tournai, c.1489. Tournai, Bibliothèque de la Ville, MS 27, fol. 1r (detail).

a secondary altar open to the deambulatory that may have been already detached from the main altar by a wall, as attested by the aforementioned depictions in Tournai and Indianapolis. ${ }^{27}$ As a consequence, pilgrims' attention would have been drawn to the enthroned image of Saint James with the tau-shaped crozier of the Compostelan archbishops, placed above the altar in much the same way as in a miniature from the so-called Tumbo B of Santiago (ACS, CF, 33; Figure 3.4). For medieval visitors, this polychrome granitic image would have been a symbolic token of the location of the apostle's relics, so it should not come as a surprise that most of the devotional practices of the pilgrims were channelled to the statue, which would also have evoked the analogous representation of St James in the Pórtico de la Gloria..$^{28}$

\section{Effigy/Icon}

In this context, the idea of having the articulated image of St James placed on the altar, side by side with the other enthroned statue of the Apostle - or even below it, as it may have been seen by people standing in the central nave - needs further comment. Albeit weird to modern eyes, simultaneous contemplation of these two divergent representations of the saint must have been the intended effect of the display, since a ceremony 


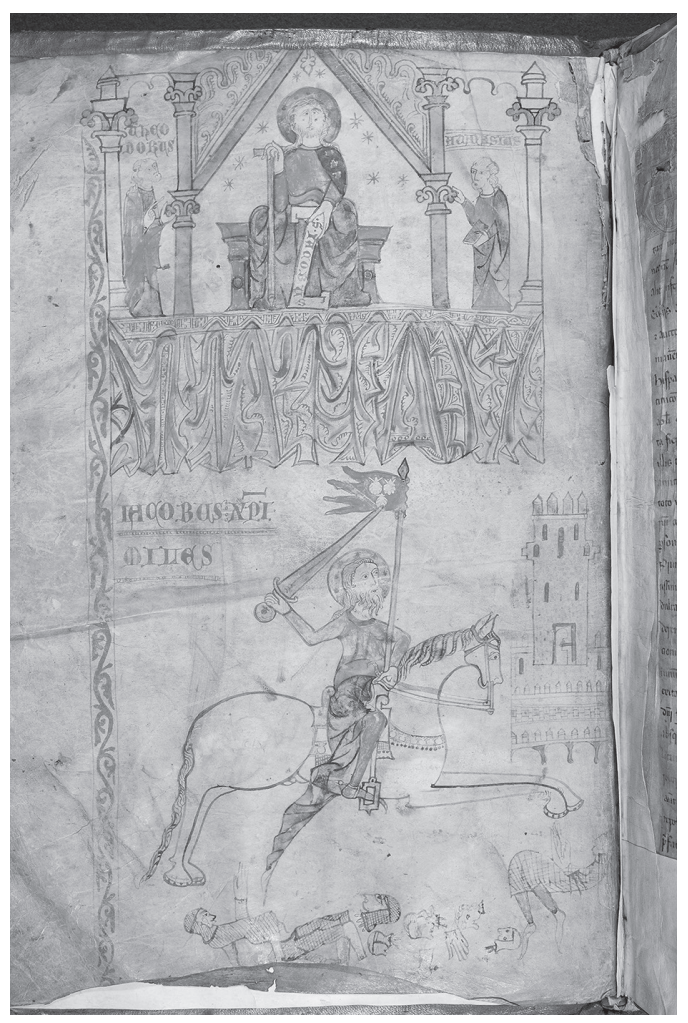

Figure 3.4 Tumbo B of the Cathedral of Santiago de Compostela, c.1326. ArchivoBiblioteca de la Catedral de Santiago de Compostela, fol. 2v (ACS, CF, 33).

of this kind would have been organised beforehand and with some assistance from the local ecclesiastical authorities. In fact, the pairing figures of St James represented as the Enthroned Apostle and as miles Christi had been established in Compostela since the thirteenth century, to the extent that in the almost contemporary Tumbo $B$ the imago of the saint is depicted on the altar while the apostle himself defeats the rebellious members of the commune in order to assert episcopal jurisdiction over the land of Santiago. ${ }^{29}$ The articulated statue would have also looked like a livelier and more active presence in comparison to the stone figure of the Apostle, although not necessarily any more 'supernatural'. The subtle distinction created between saintly remains and imago in the splendid reliquary donated to the Compostelan cathedral by Jacques Coquatrix in 1321 rather suggests that they both may have been considered as indexes of St James, whose relics were in close proximity to both representations. ${ }^{30}$

In this regard, the religious setting of this ceremony should not blind us to phenomena other than those associated with cult (or miraculous) images, which constitute the usual frame for thinking about the agency of images in the Middle Ages. ${ }^{31}$ The fact of being an articulated statue did not made of the Santiago del Espaldarazo an animated image like of the almost contemporary Cristo de Burgos, intended to create the illusion of a real presence. ${ }^{32}$ On the contrary, its very lack of artifice - the king had to 


\section{8}

Knighted by the Apostle Himself

manipulate it himself - would have been in accordance with the ultimate aim of the ritual: to solve the legal quandary posed by the un-knighted condition of Alfonso XI.

Both the political context that accounts for the whole ceremony and the relative straightforwardness of the formula chosen bring to mind the 'Farce of Ávila' (1465), when a statue of King Enrique IV of Castile was deposed of its regalia in a striking ritual that preceded the proclamation of his half-brother the infante Alfonso as new sovereign. ${ }^{33}$ As in Compostela, this apparently grotesque 'theatre of politics' helped to resolve a constitutional dilemma through the resource to a perfectly articulated notion of ius imaginum of the sort described by Ernst Kantorowicz in his The King's Two Bodies. Whereas in 1465 a persona ficta (the effigy of the king) was meant to impersonate a persona ficta (the royal dignitas), in 1332 an effigy of St James had to be crafted in order to impersonate the Apostle as patron and head of the Castilian chivalry. ${ }^{34}$ Further proof of the interest in the Compostelan milieu of the uses of images as tokens for giving visual form to legal concerns is the seal used by the Archbishop Bérenger de Landore $(\dagger 1330)$. There, the prelate is shown kneeling in front of what Serafín Moralejo defined as the 'living icon' of the Apostle (Figure 3.5), who is granting him

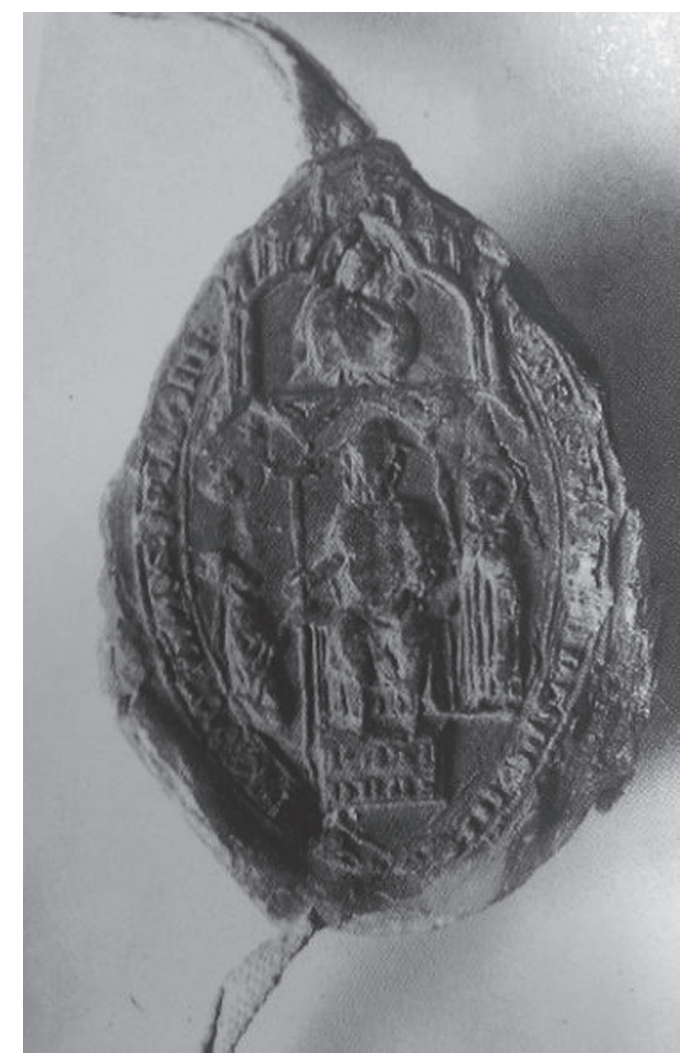

Figure 3.5 Second seal of Béranger of Landore. Archivo de la Catedral de Salamanca. Photo from: Santiago, Camiño de Europa: culto e cultura na peregrinación a Compostela, exhib. cat., Santiago, Mosteiro de San Martiño Pinario, JulySeptember, 1993 (Santiago de Compostela: Xunta de Galicia, 1993), 436. 
the tau-shaped crozier so closely associated with the Galician see. In the midst of the tensions between archbishop and commune, this gesture of traditio baculi would have metaphorically sanctioned not only the apostolic lineage of the Compostelan archbishops, but also Bérenger's secular rights over the Tierra de Santiago. ${ }^{35}$

\section{Univocity/Entropy}

From all the inconclusive evidence gathered here, it can be asserted that - despite its leading role in the ritual - any consideration of the agency of the articulated statue relies inevitably on the specific perception of the king's own agency that, for its part, would have depended on the audiences' greater or lesser awareness of the intricacies of Castilian politics, on their varying cultural education and religious sensitivity, or even on their precise location in a presumably crowded basilica for the great festivities of the Jubilee. ${ }^{36}$ What might have seemed inconceivable to French pilgrims, for whom the king was rex et basileus, could have reminded some English attendants of images such as those of the Milemete Treatise (Oxford, Christ Church, MS 92;1327) where King Edward III receives his arms from an angel (fol. 5r) and the shield of England from St George (fol. 3r), as a sign of 'divine approval' and expression of the 'special relationship' between king and national saint at the time of his knighting and coronation. ${ }^{37}$ Therefore, although Alfonso XI may have intended to 'cut an international credible figure' with his knighting ceremony, I feel that his main target was a local elite, able to grasp this highly sophisticated re-elaboration of chivalric imagery and para-liturgy tailored to the king's interests. ${ }^{38}$

Be that as it may, the explicit theatricality of the event must have captivated the viewers there gathered, regardless of the ambiguities posed by the use of the articulated statue or, perhaps, due to their very incertitude about the actual meaning of the ritual. ${ }^{39}$ Without fully adhering to Alfred Gell's notion of enchantment, I feel that the puppetlike Santiago del Espaldarazo would have based its effectiveness, paradoxically, on its ability to confound the audience's perception regarding the relative agency of the saintly prototype, the king and the image itself. ${ }^{40}$ Yet with this unresolved and entropic quality being both its virtue and its danger, it is not startling to find that the 'knighting device' was never used again nor replicated in any other form in the centuries to come.

\section{Notes}

1 This article was written with financial support from the Danish National Research Foundation (DNRF102ID). It constitutes a sort of a diptych with my 'Mística regia y ambiciones compostelanas: La Catedral de Santiago como espacio ceremonial para las monarquías castellana y portuguesa (1319-1332)', Codex Aquilarensis, 30 (2014), 133-58. I would like to express my gratitude to Peter Linehan, whose work inspires these pages.

2 Peter Linehan, History and the Historians of Medieval Spain (Oxford: Clarendon Press, 1993), 576, note 59.

3 Bonifacio Palacios, 'Los símbolos de soberanía en la Edad Media castellana. El simbolismo de la espada', in VII Centenario del Infante Fernando de la Cerda (Ciudad Real: Instituto de Estudios Manchegos, 1976), 272-96, esp. 294-6.

4 See Cayetano Rosell, Crónicas de los Reyes de Castilla (Madrid: Imprenta de Rivadeneyra, 1875), vol. I, 234. For an English translation, Peter Linehan, 'Alfonso XI of Castile and the Arm of Santiago (with a Note on the Pope's Foot'), in The Processes of Politics and the Rule of Law: Studies on the Iberian Kingdoms and Papal Rome in the Middle Ages (Farnham: Variorum Reprints, 2002), chapter VII, esp. 125. 
5 See Rocío Sánchez Ameijeiras, 'Santiago del Espaldarazo', in Santiago, camiño de Europa (Santiago de Compostela: Xunta de Galicia, 1993), 420-1, note 115.

6 Gaspar Ibáñez de Segovia Peralta y Mendoza [Marquis of Mondéjar], Memorias históricas del Rei D. Alonso el Sabio, i observaciones sobre su chronica (Madrid: Ibarra, 1777), 62-5. Cf. Linehan, History and the Historians, 426-46.

7 This legal dilemma has been minutely scrutinised by Linehan in several articles. In addition to the work referenced in the previous note, see 'The Mechanics of Monarchy: Knighting Castile's King', History Today 43 (3) (1993), 26-32, and 'The mechanization of ritual: Alfonso XI of Castile in 1332', in Riti e rituali nelle società medievali eds J. Chiffoleau et al. (Spoleto: CISAM, 1994), 309-27.

8 See, in general, Jesús Rodríguez-Velasco, Order and Chivalry: Knighthood and Citizenship in Late Medieval Castile (Philadelphia: University of Pennsylvania Press, 2010), 118-59.

9 Partida II, título XXI, ley xi. See Las Siete Partidas, trans. S. Parsons Scott, ed. Robert I Burns, 5 vols (Philadelphia: University of Pennsylvania Press, 2001).

10 See Carlos Estepa Díez, 'The Strengthening of Royal Power under Alfonso XI', in Building Legitimacy: Political Discourses and Forms of Legitimation in Medieval Societies, eds I. Alfonso, H. Kennedy and J. Escalona (Boston and Leiden: Brill, 2004), 179-222.

11 See Peter Linehan, 'Frontier Kingship. Castile 1250-1350', in La royauté sacrée dans le monde chrétien, eds A. Boureau and C. S. Ingerflom (Paris: Éditions EHESS, 1992), 71-9. For the Aragonese coronations, see Bonifacio Palacios, La coronación de los reyes de Aragón, 1204-1410. Aportación al estudio de las estructuras politicas medievales (Valencia: Universidad de Zaragoza, 1975). I remain unconvinced by José Manuel Nieto Soria's idea of Castilian sacral monarchy as discussed in his 'Tiempos y lugares de la realeza sagrada en la Castilla de los siglos XII al XV', in A la recherche de légitimités chrétiennes, ed. P. Henriet (Lyon: Annexes des CLCMH, 2003), 263-84.

12 For a detailed analysis of this MS see Rosa M. Rodríguez Porto, 'Thesaurum: La Crónica Troyana de Alfonso XI (Escorial, h.I.6) y los libros iluminados de la monarquía castellana, 1284-1369' (PhD dissertation, University of Santiago de Compostela, 2012), II, 263-336. Cf. Eduardo Carrero Santamaría, 'Architecture and Liturgical Space in the Cathedral of Santiago de Compostela: The Libro de la Coronación de los Reyes de Castilla', Hispanic Research Journal 13 (5) (2012), 468-88.

13 See Jacques Le Goff et al., Le sacre royal à l'époque de saint Louis d'aprés le manuscrit latin 1246 de la BnF (Paris: Gallimard, 2001).

14 Linehan, History and the Historians, 584-604.

15 Bonifacio Palacios, La coronación, 229-40. A rather inaccurate comparison of the Aragonese and Castilian rituals can be found in Jaume Aurell and Marta Serrano-Coll, 'The Self-Coronation of Peter the Ceremonious (1336): Historical, Liturgical, and Iconographic Representation', Speculum 89 (1) (2014), 66-95.

16 There is a gathering missing at the end of the Libro de la Coronación, but its contents can be reconstructed by consulting its source, the Pontifical of the Roman Curia (family $\gamma$ ) of which it is an almost verbatim translation. Rodríguez Porto, 'Thesaurum', II, 286-9. Cf. Michel Andrieu, Le pontifical romain au Moyen Âge, 2 vols (Città del Vaticano: Biblioteca Vaticana, 1938-41), II, 385-408.

17 Palacios, 'Los símbolos de soberanía', 283-8.

18 The Orden de la Banda was created in the spring of 1332 and it should be regarded as one of the earliest monarchical orders. In addition to the book by Rodríguez-Velasco (see note 8), see D'Arcy D. J. Boulton, The Knights of the Crown: The Monarchical Orders of Knighthood in Later Medieval Europe, 1325-1520 (Woodbridge: Boydell Press, 2000), 46-95. On the pescozada, see Rodríguez Porto, 'Mística regia', 155-6.

19 Rosell, Crónicas, I, 235-7. Rodríguez-Velasco, Order and Chivalry, 152.

20 Among the vast bibliography devoted to the topic, see Caroline Walker Bynum, Christian Materiality: An Essay on Religion in Late Medieval Europe (New York: Zone Books, 2012). On the distinction between 'image' and 'medium', see Hans Belting, An Anthropology of Images: Picture - Medium - Body (Princeton, NJ: Princeton University Press, 2011).

21 Francisco Torrón Durán, 'Imagen de Santiago del Espaldarazo de Las Huelgas de Burgos', Abrente 38-9 (2006-7), 73-4. 
22 Carrero's contention ('Architecture and Liturgical Space', 480-4) that, since the Santiago del Espaldarazo is first documented by Mondéjar at the very beginning of the eighteenth century, the statue was a postmedieval forgery lacks any solid base. It would have been a remarkable achievement for the sixteenth and seventeenth-century enclosed nuns of Las Huelgas to have perfectly imitated the style of the Burgalese sculpture c.1330 with the sole aim of deceiving contemporary erudites. Rodríguez Porto, 'Mística regia', 151-2.

23 See, in general, Bill Bryson, 'Thing Theory', Critical Inquiry 28 (1) (2001), 1-22.

24 On the Virgen de los Reyes, see Christopher Swift, 'Robot Saints', Preternature 4 (1) (2015), 52-77. Non-humanoid automata ['bestiales fechos por manos de omes que parescian vivos'] seem to have been part of the festive parade accompanying the royal entry of Alfonso XI in Seville (1327). Rodríguez Porto, 'Mística regia', 142. On automata in medieval and early modern times, see E. R. Truitt, Medieval Robots: Mechanism, Magic, Nature and Art (Philadelphia: University of Pennsylvania Press, 2015); Horst Bredekamp, The Lure of Antiquity and the Cult of the Machine: The Kunstkammer and the Evolution of Nature, Art, and Technology (Princeton, NJ: Markus Wiener, 1995).

25 '[E]t la imagen de Santiago, que estaba encima del altar, llegóse el Rey á ella, et fizole que le diese la pescozada en el carriello'. Rosell, Crónicas, I, $234 b$.

26 The original liturgical furnishings of the Romanesque altar were masterfully reconstructed by Serafín Moralejo, 'Ars sacra et sculpture romane monumentale: le trésor et le chantier de Compostelle', Cahiers de Saint-Michel de Cuxa 11 (1980), 189-238. The Tournai and Indianapolis depictions are described in Miguel Taín Guzmán, 'The Survival and Destruction of Gelmirez's Altar in the Modern Age', in Compostela and Europe: The Story of Diego Gelmírez, dir. M. C. Castiñeiras González (Milano: Skira, 2010), 166-81.

27 On the disputed arrangement of the confessio, see Serafín Moralejo, 'La imagen arquitectónica de la Catedral de Santiago de Compostela', in Il pellegrinaggio a Santiago de Compostela e la letteratura jacopea, ed. G. Scalia (Perugia: Università degli Studi di Perugia, 1983), 37-61; Eduardo Carrero Santamaría, 'Le sanctuaire de la cathédrale de Saint-Jacquesde-Compostelle à l'épreuve de la liturgie', in Saint-Martial de Limoges: ambition politique et production culturelle, Xe-XIIIe siècles, ed. C. Andrault-Schmitt (Limoges: Presses Universitaires de Limoges, 2006), 295-308; and Manuel Castiñeiras González, 'Périégesis et ekphrasis: Les descriptions de la cathédrale de Saint-Jacques-de-Compostelle entre la cité réelle et la cité idéale', Cahiers de Saint-Michel de Cuxa 44 (2013), 149-55.

28 Still extant, the image is now enclosed in the Baroque camarin under the seventeenth-century tabernacle. On the uses recorded in the Liber Constitutiones (ACS, CF 21, fols. 72r-73r; c.1240) about accession to the main altar in the morning to leave alms for the shrine and candles for the Apostle's image, see Castiñeiras González, 'Périégesis', 154-5.

29 Serafín Moralejo, 'La ilustración del Códice Calixtino de Salamanca y su contexto histórico', in La Guía del Peregrino del Calixtino de Salamanca (A Coruña: Fundación Caixa Galicia, 1993), 39-51.

30 For some enlightening remarks on the vexed question of 'representation', see Carlo Ginzburg, Wooden Eyes: Nine Reflections on Distance (London: Verso, 2002), 63-78. See also Hans Belting, Likeness and Presence: A History of the Image before the Era of Art (Chicago: Chicago University Press, 2004); and Peter Stewart, 'The Image of the Roman Emperor', in Presence: The Inherence of the Prototype within Images and Other Objects, eds R. Maniura and R. Shepherd (Aldershot: Ashgate, 2006), 243-58.

31 An exception is Horst Bredekamp, Theorie des Bildakts (Frankfurt: Suhrkamp, 2010). See also, Michele Bacci, 'Agency ed esperienza religiosa: alcuni reflessioni', Codex Aquilarensis 29 (2013), 15-22.

32 On the Cristo de Burgos and its 'claim for reality, for truth', see Elina Gertsman, 'Introduction: Bewilderment Overwhelms Me', Preternature 4 (1) (2015), 1-12, esp. 8.

33 See Angus MacKay, 'Ritual and Propaganda in Fifteenth-century Castile', Past \& Present 107 (1985), 3-43. On Kantorowicz, see Ginzburg's article (note 30).

34 MacKay, 'Ritual and Propaganda', 17-18. There is an embryonic development of a ius imaginum in relation to royal effigies, seals, coins, arms and even documents where the name of the king appears in the Partidas (II, XIII, xviii).

35 Moralejo, 'La ilustración del Códice Calixtino', 48-9. 


\section{Knighted by the Apostle Himself}

36 This paradox lies at the core of Bredekamp's notion of Bildakt, as contended by Beatrice Kitzinger in her review of the work (CAA reviews, 10 September 2014; accessed 24 October 2015 (doi: 10.3202/caa.reviews.2014.103)).

37 These striking similarities were already pointed out by Michael Michael, 'The Iconography of Kingship in the Walter of Milimete Treatise', Journal of the Warburg and Courtauld Institutes 57 (1994), 35-47. However, there is a qualitative difference between the metaphorical handing over of the arms by St George to the new king on the pages of the Milimete Treatise and the public act of being knighted by a tridimensional image of St James, which not only 'stands for' but also 'acts for' the Apostle.

38 Linehan, 'Alfonso XI of Castile and the Arm of Santiago', 202.

39 On the notion of theatrica in relation to the use of articulated sculptures and automata in liturgical and devotional practices, see Swift, 'Robot Saints', 60-1.

40 See Alfred Gell, 'The Technology of Enchantment and the Enchantment of Technology', in Anthropology, Art and Aesthetics, eds Jeremy Coote and Anthony Shelton (Oxford: Clarendon Press, 1992), 40-66, further re-elaborated in Art and Agency: An Anthropological Theory (Oxford: Clarendon Press, 1998). Cf. Howard Morphy, 'Art as a Mode of Action: Some Problems with Gell's Art and Agency', Journal of Material Culture 14 (1) (2009), 5-27. 


\title{
4 Agency and Miraculous Images
}

\author{
Robert Maniura
}

Miraculous images appear to raise the issue of the agency of things in an acute form. They are man-made objects which are treated in ways analogous to human agents and are apparently credited with a capacity to enact change in the world either by acting on something else, such as a sick human body, or by transforming themselves. How are we to deal with such material? In a characteristically direct formulation, Richard Trexler proposed an appropriate starting point for study: '. . . it needs to be said that ... no object ... has ever been miraculous in either direction.' ${ }^{1}$ Trexler's comment questions more than the identification of the agent. Implicit in his sceptical clearing of the ground is the point that images do not work miracles because miracles do not happen. The question is not just who or what is doing something, but quite what is being done. In the context of a discussion of agency, miraculous images are comprehensively problematic.

Take the case of the wall painting venerated as Santa Maria delle Carceri - Saint Mary of the Prison - in Prato which began to be associated with miraculous activity in 1484 and was enshrined in the celebrated church designed by Giuliano da Sangallo and begun in $1485 .^{2}$ The foundation miracle of the shrine rests on the experience of an eight-year-old boy, Jacopino, who is said to have witnessed the Virgin Mary get out of the picture, a fresco of the Virgin flanked by Saints Stephen and Leonard painted above a barred window of the disused and ruinous town prison, and walk around in the prison vaults. ${ }^{3}$ That spectacular animation was never repeated, but in the early months of the new devotion the figure of the Virgin was allegedly observed by many to shed tears, open and close its eyes, sweat blood and change colour. ${ }^{4}$ It also became associated with copious healing miracles. The story of one such miracle, from a collection compiled by a local lawyer, Giuliano Guizzelmi, runs as follows:

On 15 September 1484 Francesco d'Andrea di Francesco Guizzelmi of Prato, a boy of two years and eight months, had had a severe fever continuously for two days and in that time had not eaten or drunk anything and had not spoken and slept continuously and lay in his bed as if dead. And fearing this illness, Andrea his father, and my brother, went to the Madonna delle Carceri and there vowed him to Her Majesty. And that boy was as said in bed as if dead and, at the time that his father vowed him to the Madonna, he suddenly came to and sat up in bed without a fever, healthy and liberated, and said to his mother standing there and weeping, 'Mamma, the Virgin Mary has healed me.' And he began to talk and eat and drink as if he had never had any illness and was perfectly healthy and liberated. And lifted out of bed by his mother, he began to run though the house as children of 
that age do, healthy and in good spirits. Seeing this, the said Andrea, his father, and his mother thanked God and the Glorious Virgin for such grace and miracle and afterwards they went to the Madonna and prayed and offered according to their consciences. ${ }^{5}$

The writer's nephew was healed when the boy's father visited the shrine and vowed him to the Madonna of the Carceri.

Guizzelmi frames the healing story in a wholly orthodox way. When the miracle is recognised, he has the boy's parents thank God and the Virgin Mary. God is the source of healing power which is delivered on the intercession of his saintly mother. But the story revolves around an interaction with an image of her. What role is the image understood to play?

The orthodox answer is that prayers to the image are transferred to the saint depicted. ${ }^{6}$ It is, however, regularly questioned whether this nuance was either accessible to, or informed the beliefs and practices of, most devotees. It is usually suggested that the devotees regarded the image as itself generating a sacred presence with the image effectively taking the place of the saint and that this image/saint was regarded as the locus of divine power. This was central to Trexler's own approach in his pioneering study of the Madonna of Impruneta outside Florence: 'in the supplicatory process ... a practical identity existed between Mary and image . . . It was quite clear to the Florentines that they were praying to the image . . .7 The efficacious image was a 'valid, participatory intelligence'. ${ }^{8}$

This basic stance has found widespread support. In their wide-ranging study of miraculous images in Liguria, Jane Garnett and Gervase Rosser claim that 'Evident in all miraculous image stories is an implied assumption that the divinity - usually, as we have seen, in the form of the Virgin Mary - is in some sense present in the statue or the painting." This 'real presence' response, they acknowledge, embodies a tension: 'The devotee knows the limitations of the image as a compound of natural substances, manipulated by human techniques. Yet he or she also understands this object to be inhabited by a divine presence.' ${ }^{10}$ Commenting on a fifteenth-century poem presenting the miracles of Santa Maria delle Carceri in Prato which plays upon this very tension, Megan Holmes suggests that 'it is very probable, however, that many devotees experienced sacred immanence in miraculous images in ways that were more literal than that represented in the poem . . . as if the Virgin and Christ were not just manifest in their transfiguring material effigies but were physically embodied in them.' ${ }^{11}$

The Prato material quoted above can be taken to support this reading. The foundation miracle has the Virgin Mary herself emerge from the image. In the story of Francesco Guizzelmi the boy's father 'went to the Madonna of the Carceri' as if visiting the saint herself and after receiving help returned to give the image/saint gifts in thanks. The child himself asserted that he had been healed by 'the Virgin Mary'. Is the image, then, seen as an autonomous agent with the vowed child as the patient, in both technical and colloquial senses? ${ }^{12}$

Certainly the devotees behave in key respects as if the image were a sacred presence, but the unsatisfying thing about this approach is that it involves attributing to those involved conceptions which we, as Trexler highlighted, do not share. This unease has led others to seek alternative approaches. For Jason Gaiger: 
The central requirement of a theory of living-presence response . . . is to provide a means of accounting for actions that appear to attribute life or lifelike powers to objects such as stones, carvings, and paintings without having recourse to the problematic assumption that the participants have lost sight of the distinction between animate and inanimate things. ${ }^{13}$

Some commentators have implied that the participants did indeed succumb to cognitive error. ${ }^{14}$ This attitude engages uncomfortably with the motif of deception which has been central to writing on mimetic art since the classical period when, however, it was employed in literary constructions which do not obviously purport to document the incidence of actual conceptions. ${ }^{15}$ The allegation of a related error, or the risk of it, is also involved in concerns about images in the Christian tradition: to worship the stuff of the image instead of God is to fall into idolatry. These ideological entanglements make the assumption of error problematic. It is also not clear that attribution of error is plausible. The Carceri image is, for example, certainly a mimetic image in the Western tradition, and in the context of that tradition the identity of the holy figure is readily recognisable. ${ }^{16}$ But when it began to be associated with miracles it was already at least a century old and by the standards of the time its pictorial devices were not very sophisticated. Is it plausible to suggest that in the course of their devotions people 'mistook' the picture for the Virgin Mary? Vivid and potentially disorientating mimesis is not obviously an issue. ${ }^{17}$

It is increasingly acknowledged that it is necessary to go beyond the perception of the object itself and consider the miraculous image as part of a much wider network. The central role of the devotee was already part of Trexler's proposal and recent work has explored and expanded upon the dynamic interaction between the devotee and the image. ${ }^{18}$ The network comprises the physical elaboration of the shrine, as highlighted by Holmes, along with the rituals, both individual and communal, surrounding it, from the lighting of candles and the donation of other gifts to church liturgy and civic processions, and the narrative traditions, formal and informal, which articulate the site and object. ${ }^{19}$ This rich environment, what David Morgan calls the ecology of the image, also crucially engages the emotions and memories of the devotees. ${ }^{20}$

In terms of agency, this line of enquiry stresses the contribution of the devotee. The material and ritual network is a conscious and considered dramatic construction, deliberately initiated by the devotees themselves. ${ }^{21}$ The creative aspect of this environment is related to fiction: the devotees act out their devotion to the saint. ${ }^{22}$ Gaiger has pursued this parallel of engagement with fictional worlds and has suggested that we can find productive insights in the work of the philosopher of literature, Kendall Walton. The field of the avowedly fictional may seem somewhat distant from that of devotion to a miraculous image, as Gaiger admits, but the element of 'play' is acknowledged even by those who wish to stress the perception of presence. ${ }^{23}$ The issue is how far their performance is understood to take the devotee. As Garnett and Rosser comment:

We would agree with the suggestion that there is an element of creative fiction or make-believe in the behaviour of devotees who willingly suspend disbelief in a real presence within the image. Yet if there is a degree of pretence at the outset of personal engagement . . . this is not, for many, where the process of interaction with the statue or picture ends. ${ }^{24}$ 
I would like to reconsider the crucial juncture appealed to implicitly here: the climax of the devotee's engagement with the miraculous image. As Gaiger suggests, Walton offers some considerations which can help to frame an approach.

Walton's argument is based on a thought experiment about a viewer's response to a science fiction film in which, in one imagined scene, a blob of green slime appears to advance, implicitly threatening the viewer. Afterwards the viewer says that he was terrified. ${ }^{25}$ The parallel with the experience of a devotee at an image shrine is clearly not very precise because here the whole experience is of something avowedly fictional. The viewer has gone to the cinema to be entertained: there is no assumed belief in a real alien invasion which is represented in the film. At an image shrine, the holy person for whom the image stands and the idea of divine power are taken to be really existing things. The fictional element common to both is the presentation being viewed which is understood in both cases to be a man-made construction. What makes Walton's thought experiment promising is that it deals with a response involving heightened emotion.

The question, for Walton, is how we understand the viewer's professed fear. In some respects Walton's viewer responds as someone who is really frightened: adrenalin courses through his body, his heart rate increases, his palms sweat, and he tenses his muscles. But in other respects he does not behave like someone who is really frightened. He does not, crucially, run away or try to warn others of the apparent danger. He remains in his seat and continues watching the film. Walton's contention is that, even at the highest pitch of his involvement with the film, there is no point at which his viewer believes that he is actually in danger. At no point does he suspend his disbelief in the fiction.

Walton, indeed, questions what the suspension of disbelief could mean. ${ }^{26}$ If it means that at some point the viewer begins fully to invest in the reality of the depicted scene, then we would expect a fuller manifestation of fear, but that does not happen. Critically, this state of suspension cannot be understood as a momentary achievement insufficient to allow a full manifestation of responses. Our engagements with fictions, scary or otherwise, are sustained over long periods. If, on the other hand, by suspension we understand merely uncertainty then this cannot explain the behaviour: if the viewer is simply not sure whether or not the scene is real, real fear would still be the most appropriate response. For Walton, the idea of the suspension of disbelief is misleading. ${ }^{27}$ Rather, he proposes, the viewer's involvement with the fiction is itself another fiction: 'On my thesis we accomplish "decrease of distance" not by promoting fictions to our level but by descending to theirs ... Rather than somehow fooling ourselves into thinking fictions are real, we become fictional. ${ }^{28}$ The point I wish to stress here is that Walton's proposal challenges the idea of a tipping point in the response of a viewer to an image. If the viewer starts out aware that what is viewed is a fiction, is it plausible to suggest that even at a point of great emotional involvement it starts to be viewed as real?

The lack of precision of the scary film analogy is admittedly limiting. In particular, it is not clear that there is a tell-tale sign of the perception of a real presence in a devotional context such as Walton suggests running away would be for the perception of the reality of something fearful. This is at the heart of the problem. Everything that the devotee does, it seems, is 'as if' the image were a holy person. However, the idea of a 'willing suspension of disbelief' is still problematic. If we allow that the devotee accepts the artefactual nature of the cult image, how are we to understand a shift to taking it as a holy person? There seem to be only two alternatives. The first is to 
bring back into play the collapse into cognitive error that most commentators agree is implausible as a starting point, with the devotees, in Walton's terms, somehow fooling themselves. It is not clear that it is possible willingly to fool oneself, to decide to be deceived. The second is to question whether the willing suspension of disbelief is distinct from pretending. Can consciously deciding to take the image as a holy person be anything other than itself a creative fiction?

The proposal that the behaviour of the devotee at an image shrine remains selfconsciously a fiction admittedly seems unsatisfying. As Frank Graziano remarks of the implications of the church's insistence on the distinction between image and sacred figure, were it observed in practice 'the passion of devotion before images would be reduced to a form of improvised theater, a make-believe, an emotional performance for a mannequin when prayer could venerate more authentically. A prop recognized as such cannot inspire or accommodate emotional intensity; devotion wants its object to be real. ${ }^{29}$ But does devotion get what it wants? I propose that we can find cases in which props do inspire high levels of emotional intensity. It all comes down to what the prop is taken to deliver.

The role of the image at the miracle-working shrine is seen in too polarised a way as mere representation on the one hand or as real presence on the other. Images can be understood to have capacities which are not necessarily accommodated by these two extremes. Images can, for example, be understood as prosthetic devices, helping the viewer to see beyond the capacity of the unaided eye and, in some cases, enabling the viewer to see what is not physically present to them. Our own culture is very familiar with this idea in live television broadcasting and I propose that this can inform our thinking about miraculous images and the behaviour surrounding them.

The idea of live television coverage as prosthesis is especially forceful in the context of sporting events. To see the live television coverage is to be enabled to see the event. It is no real substitute for being there - it is not understood to be equivalent to being in the presence of the prototype - but it is taken to put the viewer in visual contact in a meaningful way. This is a very suggestive model for the force of the cult image. The image places the devotee in visual contact with the holy person. Pace Alberti, it is not that the image makes the absent present, but that it makes the absent visible. ${ }^{30}$

It is important that watching live television coverage not only allows the viewers to see the event, but also allows them to participate in it in a way that is emotionally involving. It has become commonplace to watch major sporting events on screens in public places and this is where the analogy with the image shrine becomes most productive. At such gatherings the viewers/supporters shout their encouragement, sing, wave flags and scarves, cheer and weep, just as they would do at the match: they behave 'as if' they were present at the event itself. Here the prop, the viewing screen, is indeed capable of accommodating high levels of emotional intensity, and this even without any promised benefit to the 'devotee'.

One reason for this capacity is that the view of the screen displaying the event is only part of the experience, which also includes interaction with the other people gathered there. Those others witness an individual's performance and their performances in turn inform and affirm it. The experience is a shared and mutually supportive one. Similarly, at an image shrine the viewer's encounter with the image is only one element of a more complex interaction. Miracle stories routinely articulate a lively awareness of the communal nature of the experience in the devotee's concern to communicate their story to others. Giuliano Guizzelmi's collection of miracles of Santa Maria delle 
Carceri in Prato has a significant number of stories in which the devotee is said to 'publicly announce' their miracle. ${ }^{31}$ In some cases a stress is placed on the large numbers of people present to hear the testimony. ${ }^{32}$ In others there is a stress on the emphatic nature of the narration: Mona Catherina di Nicolò del Grasso of Querceto proclaimed her healing 'in a loud voice'. ${ }^{33}$ In a number of the earliest dated stories, placed in August and September 1484, including that of Mona Catherina, the beneficiary of miracle was crowned with olive and processed to the established shrine of the Virgin's girdle in the nearby church of Santo Stefano. ${ }^{34}$ In some cases the procession is said to be either witnessed, or participated in, by 'all the people'. The visit to the shrine is a public performance. We should consider the possibility that the shrine image is indeed a prop. Just as there is nothing inherently special about the TV screens at the bar where people congregate to watch a sporting event, there is not perceived to be anything inherently special about the image at the shrine. What marks it out is the convention that has arisen that this is a good place to come to see the saint in the company of fellow devotees. The image acts as a focus and generates a supportive space in which one can perform one's devotions. In an important sense the devotion at an image shrine is a form of theatre, but to propose this is not to render it trivial.

However, even if the image at the shrine is understood to deliver visual contact, like the screen at a sports bar, what apparently sets it apart is the association with miracle. The devotees' interactions at the Carceri, cited above, are from stories of miracle. Even if we allow the force of the devotees' creative performances, how do we construe the devotees' understanding of the outpouring of divine power and its relationship to the image?

It is important that in the cases in Guizzelmi's collection cited above, the devotees announcing their miracles publicly at the shrine did so on arrival having obtained the miracle elsewhere in response to a vow. ${ }^{35}$ This phenomenon of the remote miracle makes any straightforward understanding of the shrine image as the source of miraculous power problematic. ${ }^{36}$ Even if the vow is addressed to 'Santa Maria delle Carceri' and entails a visit to the shrine, can the image be construed as the agent when the miracle is achieved at a distance from it? Christopher Nygren has recently shown just how statistically significant this feature is for miracles associated with image shrines and has highlighted the implications for the issue of agency. ${ }^{37}$ If, as proposed above, we drop the assumption of the saint's presence at the shrine, this diffusion of power is less perplexing: the saint's power is not strictly localised just as the saint is not strictly localised.

Ultimately, however, miracle itself is not the clear cut issue that it might first seem to be. Take the story from Guizzelmi's collection about his nephew Francesco, quoted above. The boy was sick. His father went to the Carceri, vowed him to 'Her Majesty', and the boy got better. What does the miracle consist in? There is no traceable process. The miracle lies in the votary's conviction that a miracle has occurred. The parents judge that it is the vow to the Carceri that has been the decisive factor. Elsewhere I have proposed that miracle is the devotee's redescription of the world to accommodate divine aid..$^{38}$ Graziano puts the point succinctly: 'Miracles are not events; they are interpretations. ${ }^{39}$ The construction of miracle itself is part of the work that the devotees do.

This may sound like another form of self-delusion, but recent work in psychology has pointed to the potentially beneficial effects of such seeming passivity as a way of retrieving something positive from apparently hopeless situations. What has been 
termed secondary control, defined as the process by which people 'adjust some aspect of the self and accept circumstances as they are', has been shown to help in managing feelings of helplessness and assist in coping strategies. ${ }^{40}$ Deferring to an external authority, be it a health professional, a saint or a picture of a saint, is itself an action that can lead to the recuperation of at least a sense of control in adversity. ${ }^{41}$

The miraculous image can be understood as a device manipulated by the devotee in making an accommodation with circumstances. ${ }^{42}$ This approach insists on the devotee as the primary agent, in Gell's terms, but it does not deprive the image itself of agency. ${ }^{43}$ The image is not just a prosthetic aid to sight, but a tool of crisis management which, when wielded, feeds back on the user, changing the user's relationship with the world. ${ }^{44}$ The devotees interact with the image 'as if' with the saint in mutually supportive collective performances of hope, reassurance and consolation.

The image's role in this network is by no means arbitrary. Images draw the eye: they are, as Gell argued, mechanisms of captivation and even entrapment. ${ }^{45}$ It is significant that many images associated with miracle, like that at the Carceri, were originally located outside in accessible spaces. ${ }^{46}$ We cannot know what the old prison in Prato looked like, but it seems likely that the wall painting of the Virgin and Saints was conspicuous. In the context of a given set of iconographic and devotional conventions, such images represented a ready devotional resource, ripe for exploitation by a community whose expectations were fed by news of similar activity elsewhere.

These remarks do not pretend to constitute a complete theory of response to miraculous images. I have engaged most extensively with the image's apparent action on the devotees through miraculous healing but hardly at all with the miraculous transformations of the image itself. These transformations apparently challenge the interpretation advanced here by openly articulating the image as animated, but I suggest that they stand in a different and less immediate relationship to the devotee. In the case of the Carceri, the most spectacular transformation was Jacopino's experience of seeing the Virgin get out of the picture and walk around. This transformation was, however, witnessed only by him and we have no direct access to that experience: the available accounts were written by other people. Everyone else involved in the cult encountered his experience, like us, as a story in circulation: it is something that articulates the site but is not part of a more general experience. The miracles of transformation which were reported to have a more general audience - the colour changes and eye movements - were of a much more limited kind and the available accounts of them, concentrated in the earliest months of the cult, evoke a purely visual engagement with crowds gathering to gaze at the image. ${ }^{47} \mathrm{My}$ point in stressing Guizzelmi's accounts of healing miracles, which are the exclusive focus of his book, is that his writings show that the perception of healing associated with the shrine was, by contrast, widespread, long-lasting and, on the evidence of his own first-person testimony, something with which people felt intimately and actively involved. The enduring power of Santa Maria delle Carceri as a social phenomenon was experienced pre-eminently in terms of widely distributed healing.

The distinctions discussed here between creative fiction and perceived presence are perhaps too close to call on the available evidence. One can appreciate the suppleness of Trexler's foundational proposal of 'practical identity' between image and saint: the behaviour of the devotee is the same whether we suppose that the devotee came to believe that the image was the saint or retained an awareness of it as an artefact. Indeed, I would argue that it is precisely the devotee's actions and not the ontological 
status of their focus that is the crucial devotional issue. ${ }^{48}$ However, my purpose in contesting the idea of a perception of 'real presence' has been to argue that we do not have to assume this in order to make sense of what goes on at an image shrine. My lingering concern is that the real presence argument threatens to efface the image by collapsing the shrine encounter into an unmediated experience of the divinity. It seems to me more interesting to keep the image in play and consider how devotees used it to celebrate, plead with and cajole their tantalisingly remote saints. In a discussion of agency, the miraculous image challenges and extends our understanding of what people could do with images or make images do to them.

\section{Notes}

1 Richard C. Trexler, 'Being and Non-Being: Parameters of the Miraculous in the Traditional Religious Image', in The Miraculous Image in the Late Middle Ages and Renaissance, Analecta Romana Instituti Danici, Supplementum XXXV, eds Erik Thunø and Gerhard Wolf (Rome: 'L'Erma' di Bretschneider, 2004), 15.

2 For the church see Piero Morselli and Gino Corti, La Chiesa di Santa Maria delle Carceri in Prato. Contributo di Lorenzo de' Medici e Giuliano da Sangallo alla progettazione (Florence: EDAM, 1982); Paul Davies, 'The Early History of S. Maria delle Carceri in Prato', Journal of the Society of Architectural Historians, 54 (3) (1995), 326-35; Paul Davies, 'The Madonna delle Carceri in Prato and Italian Pilgrimage Architecture', Architectural History 36 (1993), $1-18$.

3 The fullest account can be found in Giuliano di Francesco Guizzelmi, Historia della apparitione et altri miracoli di Madonna Sancta Maria del Carcere di Prato, Biblioteca Roncioniana, Prato, MS 87, fols. 8v-10r. Published in Isabella Gagliardi (ed.), 'I miracoli della Madonna delle Carceri in due codici della Biblioteca Roncioniona di Prato', in Santa Maria delle Carceri a Prato. Miracoli e devozione in un santuario toscano del Rinascimento, ed. Anna Benvenuti (Florence: Mandragora, 2005), 136-7.

4 Guizzelmi's text mentions these phenomena only in passing. Guizzelmi, Historia, f12r; Gagliardi, 'I miracoli', 137. They are treated in greater detail in an earlier mansuscript Miracoli et gratie della gloriosa Madre Vergine Maria delle Charcere di Prato, l'anno 1484, Biblioteca Roncioniana, Prato, MS 86. The transformations are listed on fols. 37r-46r. Published in Gagliardi, 'I miracoli', 121-6.

5 Guizzelmi, Historia, fols. 33v-34r:

Francesco d'Andrea di Francesco Ghuççelmi da Prato, bambino di età d'anni dua et mesi octo, havendo hauto dua dì et havendo continuo grandissima febre, et in decto tempo di dua dì non havendo mangiato né beuto cosa alcuna et non favellando et continuo dormendo, et essendo in sul lecto chome morto, et dubitando fusse amorbato, Andrea suo padre, et mio fratello, andò alla Madonna del Carcere, et quivi lo racomandò alla Sua Maiestà. Et essendo decto bambino chome è decto in sul lecto chome morto, in decto tempo che el padre lo racomandava alla Madonna, in uno tracto tornò in sé et riçossi in sul lecto sença febre, sano et libero, et dixe alla madre astante et lachrimante: 'Mamma, la Vergine Maria mi ha varito.' Et incominciò a favellare, mangiare et bere chome se mai non havesse hauto male alcuno, et al tutto fu perfectissimamente sanato et liberato; et levato della madre di su el lecto, incominciò a correre per casa chome fanno e' bambini di simile età, sano et di buona voglia. Il che visto decto Andrea suo padre et la madre Dio ringratiorono et la Vergine Gloriosa di tale gratia et miracolo, et dapoi andarono alla Madonna, et ororono et offersono secondo la loro conscientia.

Gagliardi, 'I miracoli', 142.

6 A formulation going back to St Basil in the fourth century. For a fifteenth-century Italian restatement by Antonio degli Agli see Megan Holmes, The Miraculous Image in Renaissance Florence (New Haven, CT: Yale University Press, 2013), 22. 
7 Richard C. Trexler, 'Florentine Religious Experience: The Sacred Image', Studies in the Renaissance, 19 (1972), 18 and 20-1.

8 Trexler, 'Florentine Religious Experience', 20.

9 Jane Garnett and Gervase Rosser, Spectacular Miracles: Transforming Images in Italy from the Renaissance to the Present (London: Reaktion, 2013), 49.

10 Garnett and Rosser, Spectacular Miracles, 22.

11 The poem is Lorenzo di Jacopo degli Obbizzi, Miracoli della Vergine Maria delle Carceri of about 1485. Holmes, The Miraculous Image, 182-3.

12 For the agent/patient relation see Alfred Gell, Art and Agency: An Anthropological Theory (Oxford: Oxford University Press, 1998), 21-3.

13 Jason Gaiger, 'Participatory Imagining and the Explanation of Living-Presence Response', British Journal of Aesthetics, 51 (4) (2011), 367. Caroline Bynum has argued that for the late Middle Ages this distinction was both much less stable, with matter itself regarded as fundamentally changeable and, in some sense, alive, and also much less central. Caroline Walker Bynum, Christian Materiality: An Essay on Religion in Late Medieval Europe (New York: Zone Books, 2011). Bynum is clearly right to insist that we should not neglect the theories of those contemporary with the objects under discussion (280-1) and a fuller study needs to take them into account. My aim here is more limited, namely to suggest that much of the behaviour at a miracle-working shrine can still be understood as purposive in terms accessible to our understanding of the world, that is even before a reconstruction of period conceptions.

14 André Vauchez, for example: 'La confusion croissante entre l'image et son modèle impliquait en effet la reconnaissance d'une présence active (capacité d'agir, de se mouvoir) et passive (sensibilité, capacité de pâtir et d'être offensé) dans la représentation.' André Vauchez, 'L'image vivante: quelques reflections sur les functions des representations iconographiques dans le domaine religieux en Occident aux derniers siècles du Moyen Age', in Biedni i bogaci: studia $z$ dziejów społeczeństwa $i$ kultury, ofiarowane Bronisławowi Geremkowi w sześćdziesiata rocznice urodzin, eds Maurice Aymard et al. (Warsaw: Wydawnictwo Naukowe PWN, 1992), 239.

15 See, for example, Jaś Elsner, Roman Eyes: Visuality and Subjectivity in Art and Text (Princeton, NJ: Princeton University Press, 2007), 1-26.

16 The best available illustrations can be found in Benvenuti (ed.), Santa Maria delle Carceri, 10,40 and 48 .

17 As argued by Garnett and Rosser, Spectacular Miracles, 29-30. See also Gaiger, 'Participatory Imagining', 367-8. Note, however, Holmes's corrective to the idea that cult images are usually archaic in style. Holmes, The Miraculous Image, 146-51 and 157-62.

18 'What were the active (rather than the narrative or theological) ingredients in the transferral of power? The answer: image and supplicant.' Trexler, 'Florentine Religious Experience', 18. See Bynum's comments in Christian Materiality, 111-12.

19 Holmes, The Miraculous Image, 211-55. David Morgan, 'The Ecology of Images: Seeing and the Study of Religion', Religion and Society: Advances in Research, 5 (2014), 83-105. Garnett and Rosser, Spectacular Miracles, esp. chapter 3, 109-59.

20 Morgan, 'The Ecology of Images', 90. Garnett and Rosser, Spectacular Miracles, 23, 161 and 174.

21 Garnett and Rosser relate such practices to formal rites of image consecration in, for example, the Hindu tradition. Spectacular Miracles, 110-11 and 159.

22 Robert Maniura, 'Persuading the Absent Saint: Image and Performance in Marian Devotion', Critical Inquiry, 35 (3) (2009), 649-50.

23 Gaiger, 'Participatory Imagining', 371.

24 Garnett and Rosser, Spectacular Miracles, 22-3.

25 Kendall L. Walton, 'Fearing Fictions', Journal of Philosophy, 75 (1) (1978), 5.

26 The 'willing suspension of disbelief' is proposed in Samuel Taylor Coleridge, Biographia Literaria Or, Biographical Sketches of My Literary Life and Opinions (London: Rest Fenner, 1817), vol. 2, 2.

27 Walton, 'Fearing Fictions', 7-10.

28 Walton, 'Fearing Fictions', 23. I advanced the related idea, drawing on Taussig, of an extension of the mimetic field to include the actions of the devotee. See note 22 above. 


\section{Agency and Miraculous Images}

29 Frank Graziano, Miraculous Images and Votive Offerings in Mexico (Oxford: Oxford University Press, 2016), 16.

30 'Painting possesses a truly divine power in that not only does it make the absent present (as they say of friendship), but it also represents the dead to the living many centuries later, so that they are recognized by spectators with pleasure and deep admiration for the artist.' Leon Battista Alberti, On Painting, trans. Cecil Grayson (Harmondsworth: Penguin, 1991), 60.

31 Guizzelmi regularly uses the formula 'publicamente manifestò tale grazia/miracolo', for example the sequence of stories of Giovanni di Pichone, Ser Lorenzo di Bartholomeo di Francesco, Mariotto di Pavolo, Meo d'Antonio di Francesco and Mona Sancta. Guizzelmi, Historia, fols. 60r-62r. Gagliardi, 'I miracoli', 149.

32 For example, in the stories of Marietta di Chimenti di Domenico ('presenti molti persone'), Giovanni detto Malacarne ('presente gram popolo') and Agnolo di Jacopo del Gaio ('a infinite persone'). Guizzelmi, Historia, fols. 42r, 51r and 64v. Gagliardi, 'I miracoli', 144, 146 and 150.

33 Guizzelmi, Historia, fols. 27r-v. Gagliardi, 'I miracoli', 141.

34 In the stories of Mona Pippa, Mona Camilla, Lorenzo di Pippo, Mona Catherina and Luca d'Antonio di Nanni. Guizzelmi, Historia, fols. 17r-v, 23r, 27r, 28r-29r. Gagliardi, 'I miracoli', 138-41.

35 As in the case of the sequence of stories in note 31 above. Altogether 61 of the 94 miracles related in Guizzelmi's collection are said to take place away from the shrine.

36 Robert Maniura, Pilgrimage to Images in the Fifteenth Century: The Origins of the Cult of Our Lady of Częstochowa (Woodbridge: Boydell \& Brewer, 2004), 112-155; Robert Maniura, 'Image and Relic in the Cult of Our Lady of Prato', in Images, Relics, and Devotional Practices in Medieval and Renaissance Italy, eds Sally J. Cornelison and Scott B. Montgomery, in the series Medieval and Renaissance Texts and Studies (Tempe, AZ: Arizona Center for Medieval and Renaissance Studies, 2005), 206-8.

37 Christopher J. Nygren, 'Non-Agentive Efficacy: Some Data on Presence, Absence and the Ontological Entanglement of Miraculous Images', in Presence and Agency (Leiden: Leiden University Press, forthcoming). I am grateful to Dr Nygren for giving me access to his article.

38 Robert Maniura, 'Ex Votos, Art and Pious Performance', Oxford Art Journal, 32 (3) (2009): 422; Maniura, 'Persuading the Absent Saint', 652-3.

39 Graziano, Miraculous Images, 128.

40 Beth Morling and Sharrilyn Evered, 'Secondary Control Reviewed and Defined', Psychological Bulletin, 132 (2) (2006): 269-96. The proposed definition is on p. 272.

41 The relevance of these ideas to miracle-working shrines is discussed in Graziano, Miraculous Images, 166-8.

42 For the image as interactive device, see Morgan, 'The Ecology of Images', 87-90.

43 Gell, Art and Agency, 20.

44 For the tool acting on the user see Gell, Art and Agency, 21.

45 Gell, Art and Agency, 68-95.

46 As at the Carceri, this is sometimes verifiable, for example Santa Maria al Calcinaio outside Cortona and the Madonna dei Ricci in Florence. Pietro Matracchi, La chiesa di S. Maria delle Grazie al Calcinaio presso Cortona e l'opera di Francesco di Giorgio (Calosci, 1992); William J. Connell and Giles Constable, 'Sacrilege and Redemption in Renaissance Florence: The Case of Antonio Rinaldeschi', Journal of the Warburg and Courtauld Institutes, 61 (1998), 53-92.

47 Miracoli et gratie, fols. 37r-38v. Gagliardi, 'I miracoli', 121-2.

48 This engages with the approach of anthropologist R. R. Marett for whom 'religion [for him 'savage religion'] is something not so much thought out as danced out'. R. R. Marett, The Threshold of Religion, 2nd edn (London: Methuen, 1914), xxxi. I am grateful to the anonymous readers for this observation. 


\title{
5 Agency, Beauty and the Late Medieval Sculptural Encounter
}

\author{
Peter Dent
}

There is a rich poetic tradition of granting agency to sculptural works. One of the most celebrated examples comes from early in the twentieth century with the sonnet 'Archaic Torso of Apollo' by the German poet Rainer Maria Rilke. Written in Paris in the early summer of 1908, the poem was published in November of the same year as the opening piece in the second part of the New Poems, a collection dedicated to Rodin. Rilke had already written his famous essays on Rodin by this date and had worked as his secretary. The poem is as much about the French sculptor's work and his ideas about sculpture as it is about the ancient mutilated statue of its title (Figure 5.1). ${ }^{1}$
Unheard - his unimaginable head, its apple-pupils ripening. We have not known it.
But the torso still glows like a candelabrum, in which his gaze, only screwed back yet, just holds and shines. Otherwise the outline of the breast could not blind you, and that tranquil curve of the thighs send no curved smile to that procreative centre of his line.
This stone would stand disfigured, marred, small below the shoulders' sheened fall and would not glimmer like a predatory pelt; and would not burst right through its confines, like a star: for there's no place in it that does not see you. You must change your life. ${ }^{2}$

In the memorable final lines, the bust fixes the viewer with its many eyes and speaks an ultimatum: 'You must change your life.' The sonnet vividly captures the powerful agency of the object over the beholder. The poet articulates this agency by granting the headless torso the most expressive features of the face: the eyes and mouth. This extreme form of prosopopoeia can be found elsewhere in Rilke's reaction to sculptural objects. In a letter to his wife, Clara, following his first encounter with Rodin's work and collection in the house and gardens at Meudon, Rilke writes: 'everything is full of the most wonderful antiquities that associate with his dear things as with relatives, the only ones they have, happy, when the thousand eyes in their bodies open, not to be looking out into an unfamiliar world. ${ }^{3}$ The same thoughts, with the emphasis shifted to the mouth, recur in his first essay on Rodin: 


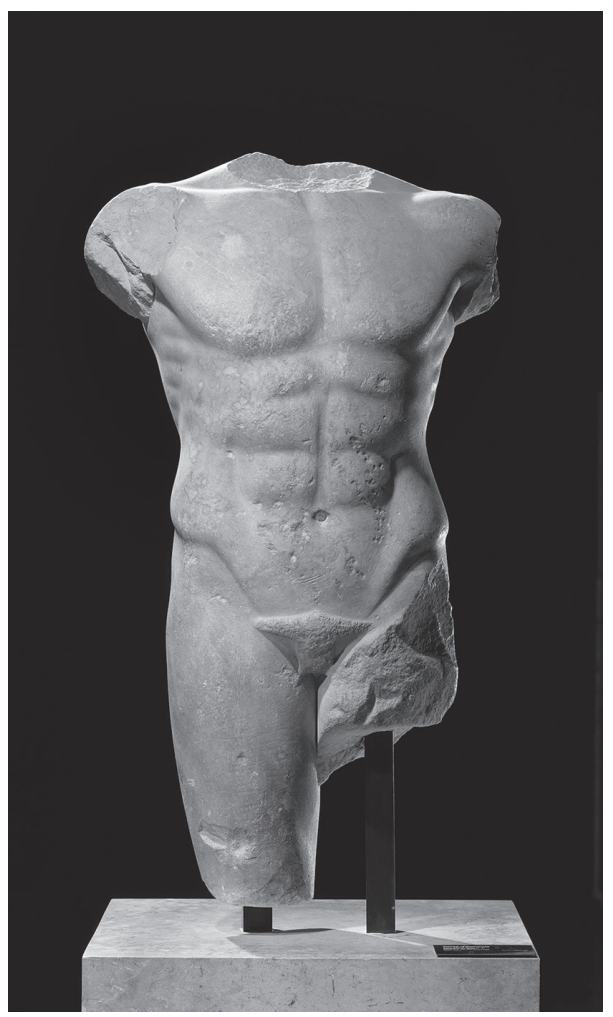

Figure 5.1 Male torso from Miletus, marble, c.480-470 BCE. Paris, Musée du Louvre.

Here was a life-sized nude figure showing life which was not only equally great in every part but which was, as it seemed, everywhere endowed with the same sublimity of expression. What was expressed in the face, the pain and effort of awakening together with the desire for this awakening, was written on the least part of the body; each part was a mouth uttering it in its own manner. ${ }^{4}$

Across these three versions of the idea, an interesting shift occurs with the sonnet as its culmination. At Meudon, the prosopopoeia articulates the remarkable communication between ancient and modern sculpture across a temporal and cultural chasm. In the sonnet, that communicative force has been directed over the same gulf but this time towards a viewer. The final line of the sonnet - Du mußt dein Leben ändern is particularly powerful in this respect. As has long been recognised, it rewrites the Apollonian injunction from the god's major temple at Delphi: Know thyself!

In the sonnet, the agency of an object transcends its historical origins. Rilke is suggesting that the modern viewer can still be provoked by the powerful agency possessed by this torso even though it is now dislocated in time and space from the cultural environment that gave it birth. Indeed, the power - the agency - of the work is communicated through a deliberately modern metaphor, the gas lamp whose glow is 
turned down but which still burns. This juxtaposition of ancient and modern is very much to Rilke's point, not least because it is framed by the implicit juxtaposition of the ancient work with Rodin's sculpture.

In other words, Rilke is at one level making an important if obvious point, one that raises fundamental if familiar questions for a history of the agency of things: what happens when we put agency in the past? Every effort at art history, for example, grapples at some level with the persistence of the past in the present and will struggle with the difficulties of returning the art object to its previous life in a manner that will not leave it entirely stranded in the 'here and now' like a foreign body, that is to say like a curiosity made for other people in other places on whom it had an effect that we can talk about but only experience with difficulty. However, when we recast our art historical interest in terms of agency, the potential dynamism of the model raises such problems in a more acute fashion. If we are to historicise agency, for example, does this simply mean historicising the object by restoring it to a context where its agency first operated or, in more radical fashion, do we need to historicise the general model of agency itself? Do we disregard any agency the object possesses in the present or do we take that as an indication of its former power? Will that agency have changed over time and, if so, how? And so the questions multiply.

There are many routes through these issues but Rilke offers one possible point of departure if we follow him to the source of his imagery. ${ }^{5}$ The idea of an eye-studded work can almost certainly be traced back to a passage from Hegel's Lectures on Aesthetics:

Now as the pulsating heart shows itself all over the surface of the human . . . body, so in the same sense it is to be asserted of art that it has to convert every shape in all points of its visible surface into an eye, which is the seat of the soul and brings the spirit into appearance ... so ... art makes every one of its productions into a thousand-eyed Argus, whereby the inner soul and spirit is seen at every point. ${ }^{6}$

Hegel's striking image of the work of art as Argus caps the opening paragraph of the section entitled 'Beautiful Individuality' with which he begins his discussion of 'The Beauty of Art or the Ideal'. The agency of Rilke's torso is the agency of the modern, supremely expressive work of art that can communicate even through the abstractions of its multifaceted surface, and this communicative transparency is nothing less than a revelation of ideal beauty. In the context of the sonnet, the shining through of beauty that 'burst[s] right through its confines, like a star' is entirely appropriate to Apollo, the Sun God and most beautiful of the male deities. In other words, Rilke implicitly indicates that one way of articulating the agency of an object is to name that power 'beauty'.

It might seem like a reactionary step to offer aesthetic beauty as one way of defining the agency of the work of art. As a discipline, recent art history has tended to avoid beauty as an analytical term because of the relative value judgements that it inevitably entails. $^{7}$ The definitions of beauty are culturally and historically specific. While past standards of beauty are of interest to art history, the impact of beauty - however defined - on the art historian in the here and now is most often tactfully set to one side. Beauty is even more taboo in recent discussions of agency within the discipline, many of which take Alfred Gell's work as a point of departure. In the essay 'The 
Technology of Enchantment and the Enchantment of Technology', Gell is blunt in his rejection of aesthetics as a meaningful approach to the anthropology of art: 'I continue to believe ... that the first step which has to be taken in devising an anthropology of art is to make a complete break with aesthetics. ${ }^{8}$ He advocates the cultivation of a 'methodological philistinism ... an attitude of resolute indifference towards the aesthetic value of works of art - the aesthetic value that they have, either indigenously, or from the standpoint of universal aestheticism. ${ }^{.9}$ Indeed, this is a necessary step towards 'the ultimate aim of the [anthropology of art] the dissolution of art'. ${ }^{10}$ Although Gell was somewhat less explicit in his rejection of art and aesthetics in Art and Agency, the opening chapter is in part an expansion of this same theme. ${ }^{11}$

Such assertions are problematic for any suggestion that beauty is a form of agency given that the nature of beauty is a central concern of aesthetic theory. Gell's rejection is twofold. First, he is opposed to aesthetics as an analytical framework in so far as it seals art from other spheres of cultural activity, preserving it as a special category of object. In other words, this is aesthetics after Kant in which aesthetic beauty is defined as something quite different from everyday beauty. ${ }^{12}$ Although Gell does not spell it out, the 'disinterested' nature of the experience of aesthetic beauty is a problem for the type of object-mediated agency that Gell develops. If art has nothing to do with the gratification of our desires then it can hardly function as an effective trap in the way he envisages. ${ }^{13}$ At a second level, his rejection concerns the historically specific discussion of aesthetics undertaken by art historians, whose representative within Art and Agency is Baxandall and his period eye. ${ }^{14}$ Gell has no desire to undertake the anthropological equivalent, that is to explore culturally specific definitions of art. His ambition in Art and Agency is to establish for the anthropology of art the kind of universal reach previously claimed by aesthetics itself.

And yet, no sooner is aesthetic beauty eliminated than beauty itself as a defining quality of the art work floods back in. This is most obvious in the earlier essay on the technology of enchantment: 'A major deficiency of the aesthetic approach is that art objects are not the only aesthetically valued objects around ... but art objects are the only objects around which are beautifully made, or made beautiful. ${ }^{15}$ In rejecting aesthetics, Gell also admits the risk of losing 'the capacity of the aesthetic approach to illuminate the specific objective characteristics of the art object as an object'. ${ }^{16}$ The way in which Gell places the object at the heart of his theory of agency is one of the elements that has attracted art historians to his work, even if the socalled Gellograms threaten sometimes to become substitute objects within the text. And yet, Gell also recognises a danger here. In dealing with the object, we must not succumb 'to the fascination which all well-made art objects exert on the mind attuned to their aesthetic properties'. ${ }^{17}$ In other words, there is an ambivalence in Gell's work towards aesthetic value.

We can see the same ambivalence emerge in a small number of places in Art and Agency where the possibility of the 'aesthetic' as a form of agency surfaces. Most notably this occurs when Gell introduces the fundamental core of the art nexus, the relationship between the Index-agent and the Recipient-patient. As Gell puts it: 'This is the elementary formula for passive spectatorship .... Whoever allows his or her attention to be attracted to an index, and submits to its power, appeal, or fascination, is a patient, responding to the agency inherent in the index. ${ }^{18}$ Gell then goes on to note: 'This agency may be physical, spiritual, political, etc. as well as "aesthetic".' 
The subsequent discussion offers the example of a warrior's shield decorated in such a way as to terrify and demoralise the enemy. In Gell's view, the designs produce terror 'because, submitting to their fascination, we are obliged to share in the emotion which they objectify .... The Asmat shield is a false mirror, which seems to show the victim his own terror.' Gell then substitutes a more familiar European work of art for the shield: 'Like the famous trompe-l'oeil image (by Parmigianino) of the Medusa's head in the mirror of Perseus (in the Uffizi gallery) the shield terrifies by persuading us that we are what it shows. ${ }^{19}$ There is a fascinating slip in this sentence that no doubt would have been corrected (or possibly unpacked) had Gell lived to thoroughly revise the typescript himself, but a slip which is revealing nevertheless. The Uffizi Medusa is by Caravaggio, but Parmigianino of course did produce a circular 'mirror-image', the celebrated Self-portrait in a convex mirror (Kunsthistorisches Museum, Vienna, oil on panel c.1524). The apparent elision of the Medusa and the self-portrait in Gell's mind is understandable in the context of the point he is making, and Gell swiftly moves on without pausing to consider his choice of image any further. However, the Medusa and the self-portrait bear further attention, particularly in the context of thinking about aesthetic agency.

At first glance, we might wonder what if anything the horrific figure of the Medusa has to do with the question of beauty as a type of agency. However, there is a tradition running through the medieval period and on into modernity of interpreting Medusa's power as a type of exterior beauty so entrancing that it captures (and petrifies) the viewer without hope of escape. ${ }^{20}$ In other words the Medusa possesses a beauty that results in an ideal 'passive spectatorship', one frozen forever in contemplation of the index. The same can also be said of Parmigianino's Self-portrait. It is generally accepted that Parmigianino was playing here with the myth of Narcissus, identified as an origin story for the art of painting itself by Alberti in Della pittura. In Ovid's version of Narcissus's tale, the beautiful youth falls under the spell of his own reflection so profoundly that - like the victim of Medusa - he too is petrified by the sight: 'He lay on the ground, perfectly still, like a statue carved from Parian marble, staring at his mirror image, himself amazed at himself.' ${ }^{21}$ In other words, fascination with one's own beauty also produces 'passive spectatorship', equally frozen in contemplation of the index: Narcissus 'never got his fill of gazing, and perished through his own eyes.' 22 In this sense, both images - the one intended by Gell, the other accidentally invoked - present the aesthetic agency of the object as paradoxically static. Indeed, the static nature of the fascination that the object itself generates (and not the agency working through it) is characteristic of Gell's attitude towards the art work: 'Every work of art that works is like . . a trap or a snare that impedes passage; and what is any art gallery but a place of capture, set with ... "thought traps", which hold their victims for a time, in suspension?"23 But suspension - or petrification - seems an overly reductive way of describing the power of objects (indexes) to shape a dynamic experience that depends upon their medial qualities and which evolves throughout the duration of their hold over the viewer's (recipient's) attention. Gell escapes the disinterested viewer of modern aesthetics only to immobilise the viewer as a passive spectator. Beauty in Gell's model is not at all the injunction radiated by Rilke's antique torso - Du mußt dein Leben ändernthat the viewer needs to change. 
One way of addressing the strange lack of dynamism at the heart of Gell's model of agency is to draw on a pre-modern way of articulating the role of beauty as a fundamentally dynamic property of the object. This pre-modern alternative to post-Kantian aesthetics will be introduced first through a text, Dante's Commedia, in which sculptural images fascinate a viewer. ${ }^{24}$ Like Rilke's sonnet, the beauty of these images is made manifest as both light and speech. This sculptural encounter occurs as the Dante-character enters the first of seven ledges on the mountain of Purgatory. In the present context, it is important to note that Purgatory is a realm expressly concerned with the possibility of change that lies between two other realms - Hell and Heaven that are fundamentally unchanging. The inhabitants of Hell and Heaven are already damned and blessed, but the penitent sinners in Purgatory are still journeying towards their salvation. Karlheinz Stierle has argued, for this very reason, that Dante dwells in Purgatory on the nature of the different arts because of the power of artworks to generate change in their audiences. ${ }^{25}$ Indeed, before the Dante-character meets any of the repentant sinners, the first thing he encounters are works of art, three sculptural reliefs depicting the Annunciation, David dancing before the Ark, and Trajan and the Widow. Each image represents an act of humility. At one level, the purpose of these works is to reform those purging the sin of pride on this terrace of the mountain. In this respect, it is noticeable that the Dante-character's experience of the reliefs is framed by a shift in agency. When he arrives on the ledge, he is the active participant, the agency lies with him. This is captured through the dramatic power of his sense of sight: his eye runs as far as it can wing its flight [e quanto l'occhio mio potea trar d'ale, Purg. X: 25]. The ancient extramission model of vision in which the eye emits a ray of light articulates his freedom to act. But in front of the final relief in the sequence of three, extramission switches to intromission as light from the relief pours into his eyes, illuminating him in all senses of the word. Here Dante deliberately uses a passive construction: 'shone white on me' [mi biancheggiava, Purg. X: 72; my translation]. In other words, agency belongs to the object. It is after looking at this last relief that Dante understands the more fundamental purpose of the images, to keep him moving in the right direction towards the ultimate object of his desire, God. Indeed, Dante's reliefs are effectively saying to the Dante-character and the penitent sinners exactly what Rilke's torso says: You must change your life! And like the star burst that heralds Apollo's presence in the sonnet, the diffusion of light from the relief points back to God.

But Dante's text offers something more substantial. The sculptural encounter is integrated into a fully developed vision of the world, a world through which a viewer travels, a viewer who is constantly shaped and changed, even at an existential level, by his encounters, of which the sculptural reliefs are only one. However, the episode with the reliefs gives us a special insight into the type of agency that objects and not just souls possess in this otherworldly realm. The opening description of the viewer's agency as expressed in his extromissive sight is lifted directly from Augustine's Confessions and it occurs at a crucial point in that text, just as Augustine begins to search for God in the world around him. ${ }^{26}$ This search becomes an interrogation: 'And what is the object of my love? I asked the earth and it said: "it is not I."' Augustine puts the same question to the sea, to living creatures, to the elements, to the sun, moon and stars and they cry out with a great voice, 'We are not your God, look beyond us . . .. He made us.' The interrogation complete, he concludes with these words: 'My question was the attention I gave to them, and their response was their beauty.' In other words the voice that 
conveys the force of their agency is their beauty. Augustine's experience operates like a dialogue. He asks; the objects answer and in turn offer an injunction: 'We are not your God, look beyond us.' This is certainly, as I have argued elsewhere, one of the levels at which Dante's description of the sculptural reliefs on the Ledge of Pride is operating. By way of confirmation, within the poem, immediately after the reliefs have been viewed, they are called 'visible speech' [visibile parlare, Purg. X: 95].

Dante's visible speech, rooted in Augustine's beauty as voice, which in turn is rooted in pre-Christian philosophy, offers a historically grounded way of talking about the agency of things that is also compatible with the type of model developed by Gell in so far as it has nothing to do with disinterested aesthetic contemplation. The beauty of the work of art is a call to which the viewer must respond. ${ }^{27}$ Moreover, it supplements Gell's model of beauty as entrapment or enchantment by offering a more dialogic and existential experience of beauty. This is beauty as the rhetorical character of the work. Mary Carruthers has recently argued that the discussion of beauty in medieval works of art can be usefully refocused through the vocabulary of style employed in rhetoric. ${ }^{28}$ This rhetorical character, manifest in the aesthetic qualities of the object, is designed to act as a persuasive force on the viewer. As such, it can be understood as a form of agency: 'In rhetorical analysis, an artefact has direct agency as it offers means of persuasion, and persuasion is an action, a process not a state. ${ }^{29}$ Augustine's words, quoted above, are particularly apt here: the viewer's attention is a question and the object's aesthetic qualities are a response. Once this dialogue is underway, the work leads the viewer on a journey. ${ }^{30}$ The idea of visible speech, of beauty as a voice, dovetails very neatly with the conceptual framework advanced by Carruthers. ${ }^{31}$ Indeed, in the passage from the Commedia we see exactly this type of dialogue evolve through the Dante-character's experience, once his attention has been captured by the reliefs. As his eyes rove across the images ['I turned my eyes': 'mi mossi col viso', Purg. X: 49], new features engage his interest ['I saw behind Mary ... another story carved in the rock': vedea / di retro da Maria ... I . . . un'altra storia ne la roccia imposta, Purg. X: 49-52], and he moves towards them ['I crossed beyond Virgil and drew near it, so that it would be wholly before my eyes': per ch'io varcai Virgilio, e fe'mi presso, / acciò che fosse a li occhi miei disposta, Purg. X: 53-4]. This is a wonderfully realised description of a dynamic encounter in which the beholder is drawn into a medially specific interaction with a sculptural object.

With that in mind, I would like to conclude by briefly considering some late medieval sculpted crucifixes. Like Rilke's image of Apollo, such works represent a deity. They are undoubtedly intended - even though they are images of an abject and tortured body - as beautiful objects of desire. ${ }^{32}$ Fundamentally, they are designed to provoke change in the viewer, from the pride of sin to the humility of repentance (like Dante's reliefs). Even at the simplest level we can see how this injunction to change is achieved through their medial and formal properties. Indeed, focusing narrowly on a description of the type of formal visual qualities that have traditionally been discussed in a rather static fashion, it can be argued that such qualities could usefully be redescribed as a kind of visual speech, especially when they coalesce in a particular way that captures the attention and appears to require a response of some sort.

Images of Christ crucified on the cross not only offer an intense version of dialogue between beholder and object, but also an opportunity for such dialogue that was widely available to late medieval viewers of all types. This means that they can function as paradigmatic examples in this period of the idea of beauty as a call that invites 
a response. Dialogue is embedded within the encounter at various levels. There is the literal dialogue of the words Christ speaks from the cross before he dies. Standing by the foot of cross, the late medieval viewer was increasingly encouraged to enter imaginatively into the experience of the original witnesses at the crucifixion, figures such as Mary, John, Mary Magdalene and Longinus. Indeed, dramatic re-enactments of the Passion might involve sculpted crucifixes playing the role of Christ alongside live 'actors' who carried on a dialogue in speech and gesture with the object. ${ }^{33}$ This literal dialogue is supplemented by a more generalised habit of addressing the crucifix with prayer. Such prayers were not just directed at Christ's face but also at his wounds. ${ }^{34}$ Miracle tales offered the possibility that such prayer might be answered by the image itself. At the end of the thirteenth century, for example, Fra Giacomo Bianconi of Bevagna commissioned a sculpted crucifix and prayed to it for a sign of his salvation. The crucifix immediately replied - 'let this be a sign' - before spurting blood and water from its side wound onto his lips. ${ }^{35}$ But beyond these cases of spoken dialogue, the late medieval image of Christ's crucified body also takes on an increasingly 'rhetorical' character. The detail of many of the most grotesque sculpted crucifixes that spread throughout Europe during the fourteenth century was supplied by the prophetic speech of Old Testament scripture. Passages from books such as Isaiah, Lamentations and Psalms were read as descriptions of Christ's suffering during the Passion, legitimating a multiplication of wounds, for example, across his entire body. ${ }^{36}$ These texts were also those read out in the Easter liturgy, when images of Christ on the cross were a particular focus of attention, or built into the dramatic performances staged during Easter Week. ${ }^{37}$ Viewed in this way, the devotee not only clothes the body of Christ with prayers, but that body itself is already patterned with the words of Scripture. The idea of Christ's wounds, for example, as orifices that 'speak' as well as bleed provides one way of interpreting several fourteenth-century crucifixes that incorporate a formal alignment between the mouth and the side wound..$^{38}$ A particularly striking crucifix of this sort, attributed to the Italian sculptor Marco Romano, survives at Colle di Val d'Elsa. ${ }^{39}$ To Christ's right, the viewer is greeted not only by Christ's direct gaze as he cries out, but also by the aperture of the side wound, complete with 'lips', that gapes in imitation of the open mouth above (Figure 5.2). The formal parallel extends into the body the sense of dialogue established by the face. Crucially, in such cases the connection forms a bridge from literal dialogue with Christ into a visual dialogue offered by the formal qualities of the object. Indeed, the crucifix becomes a place where such a relationship can be learned and enjoyed without the explicit apparatus of theology that underpins the examples drawn from Dante and Augustine. The injunctions to pay attention to the Crucifix, to fix your gaze upon Christ's body, to read it and to address it with prayer or with words supplied by scripture were all delivered in vernacular sermons and texts. ${ }^{40}$ In other words, viewers approached images of the crucified Christ with an expectation of dialogue operating at various levels. Even approaching such objects with the focused attention of the art historian rather than the devotee, the changing intensity of the formal address allows us to hear elements of this dialogue on our journey around and through the sculpture.

Two indicative examples in which the rhetorical beauty of the formal elements differs in both power and address can serve to demonstrate this point. The first contains something like a visual shout, a feature that is hard to miss, although its presence is not initially apparent because it is only discovered during the course of the encounter. The sculpture in question is a polychromed wooden crucifix originally from Sant'Aniello a 


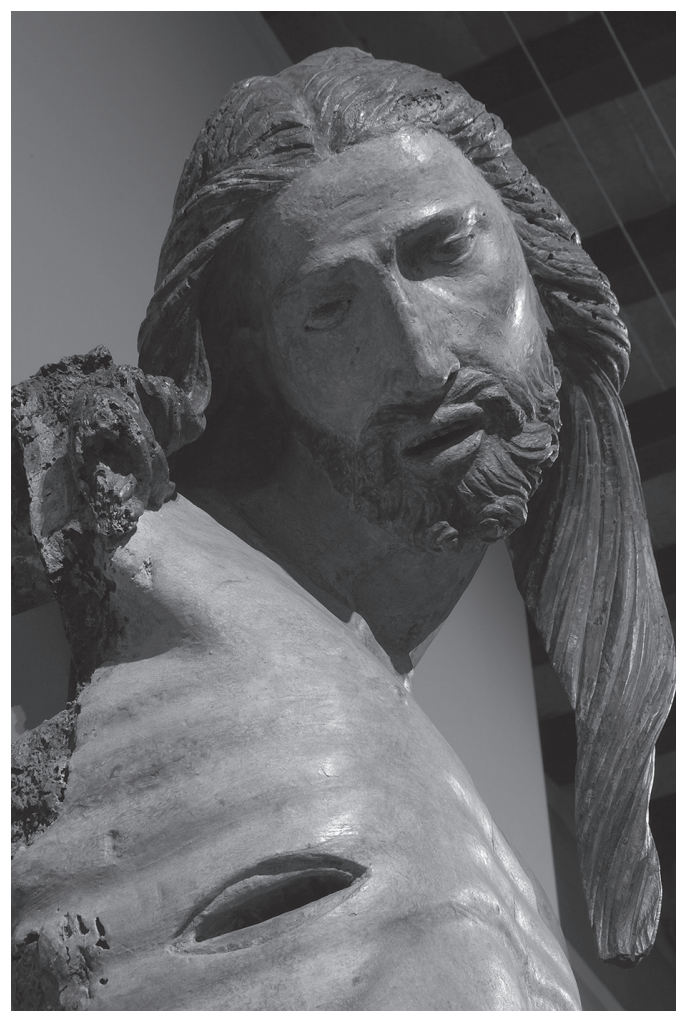

Figure 5.2 Marco Romano, Crucifix, detail, polychromed wood, second decade of the fourteenth century(?). Colle di Val d'Elsa, Museo Civico e Diocesano.

Caponapoli in Naples, probably dating to the early fourteenth century (Figure 5.3). ${ }^{41}$ Seen from the canonical frontal view - the starting point for any interaction given that it is the one most available from a distance - the work addresses the viewer in an entirely unremarkable fashion. But sculptural objects - as the Dante-character in Purgatory demonstrates - contain multiple angles of view. Once our attention is captured and we begin our journey through the work, approaching, perhaps in the hope of opening up an opportunity for literal dialogue by moving into a location where we can look Christ's bowed head full in the face, we arrive eventually at a view from below. In this subordinate position, a formally elaborate, almost baroque swirl of drapery calls to the beholder with sudden rhetorical directness (Figure 5.4). This flourish pulls our attention up towards the next stage of the encounter as we see that Christ's eyes are open and now, along the same axis, the bleeding side wound also comes into focus in a way that reconfigures the drapery fugue as an extension of the flow of blood. The second example is more subtle but, coming to it primed by the directness of the Naples crucifix and the formal strategy adopted there, the expectation of a possible dialogue helps to focus interrogation of the object (our attention) in the appropriate location. In this case, the work is a slightly earlier crucifix attributed to Giovanni Pisano now in the church of San Nicola in Pisa (Figure 5.5). ${ }^{42}$ Again, the frontal canonical view is 


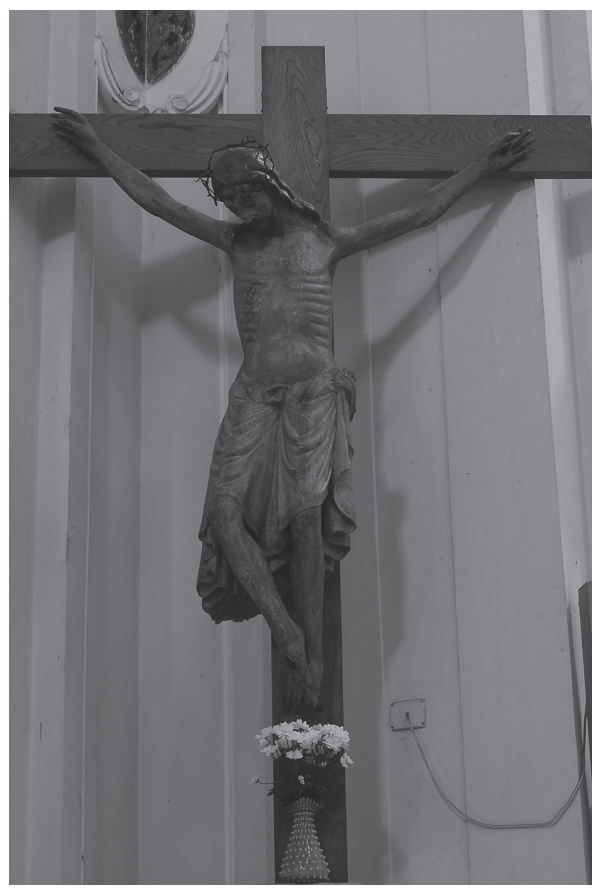

Figure 5.3 Italian sculptor, Crucifix, polychromed wood, fourteenth century. Naples, Santa Maria di Constantinopoli.

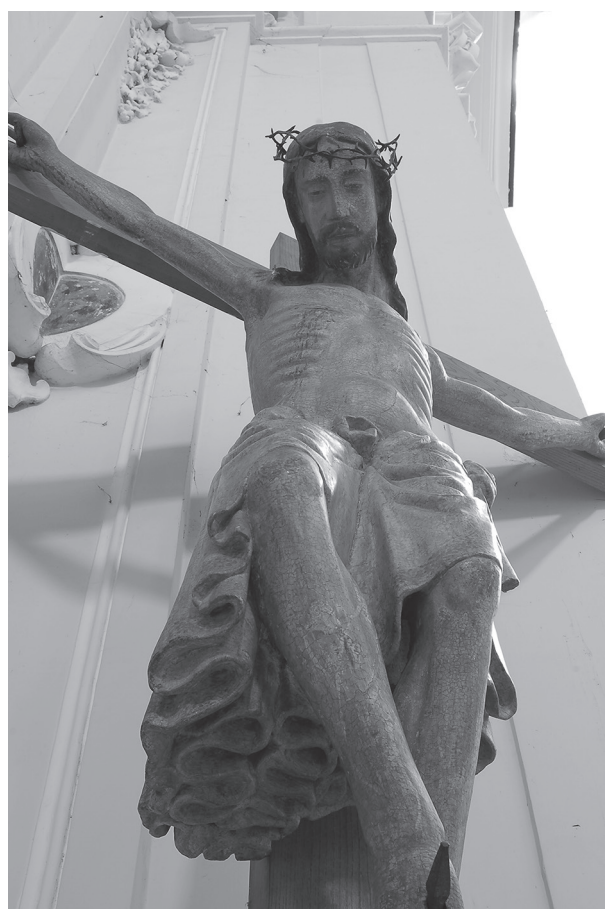

Figure 5.4 Detail of Figure 5.3. 


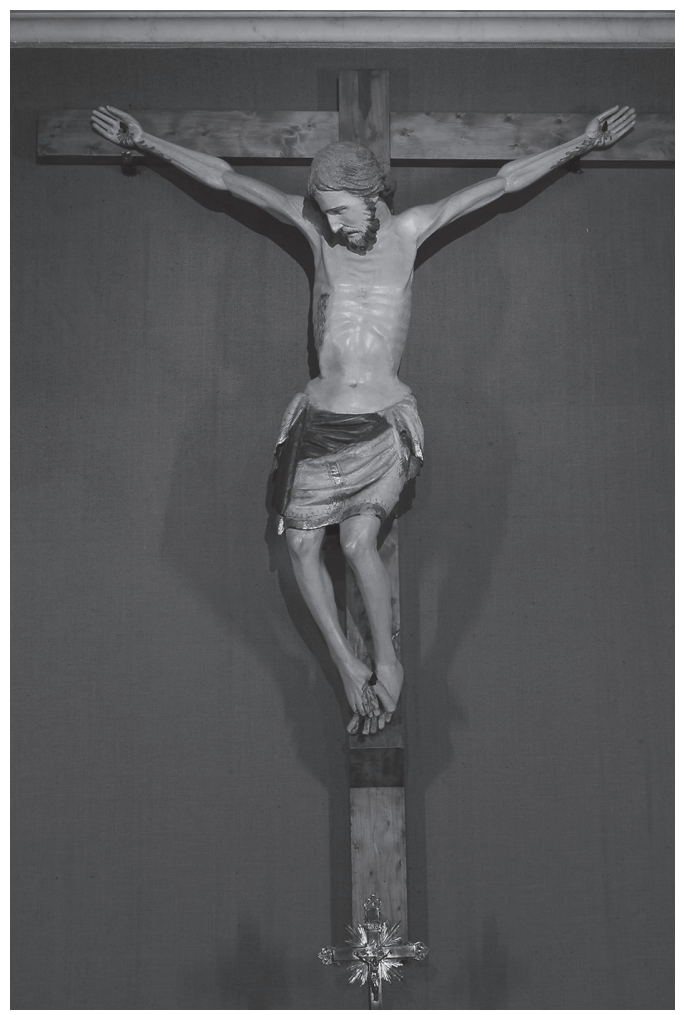

Figure 5.5 Giovanni Pisano, Crucifix, polychromed wood, c.1300. Pisa, San Nicola.

interesting but not dramatically different from the previous example. This time, the path through the work is also more complex: there are interesting features to both left and right that develop in formally engaging ways as we approach. However, following the same desire as at Naples to locate the zone where we can look up at Christ's face in order to open up the possibility of literal dialogue, we are led to the left where a set of delicate formal correspondences begins to emerge and then crystallises (Figure 5.6). The curved swags of cloth that run out across the knees mirror the arch of the rib cage. The lappets hanging down across the thigh pick up the flow of blood from Christ's side wound. Even the intersection of pectoral muscle and armpit finds its echo in a kink along the upper edge of the loin cloth. These formal resonances are less dramatic than at Naples but once again - if our question is our attention - they offer a structured response to the viewer that raises the level of dialogue between subject and object to a heightened state at this particular location. Again, at the centre of this view are the side wound and Christ's face with its open eyes and mouth: the formal correspondences framing this approach are an extension of the dialogue these representational features collectively imply.

In both of these crucifixes, once the formal address to the viewer is identified we can begin to think about what kind of question is being asked..$^{43}$ In each, the visible beauty 


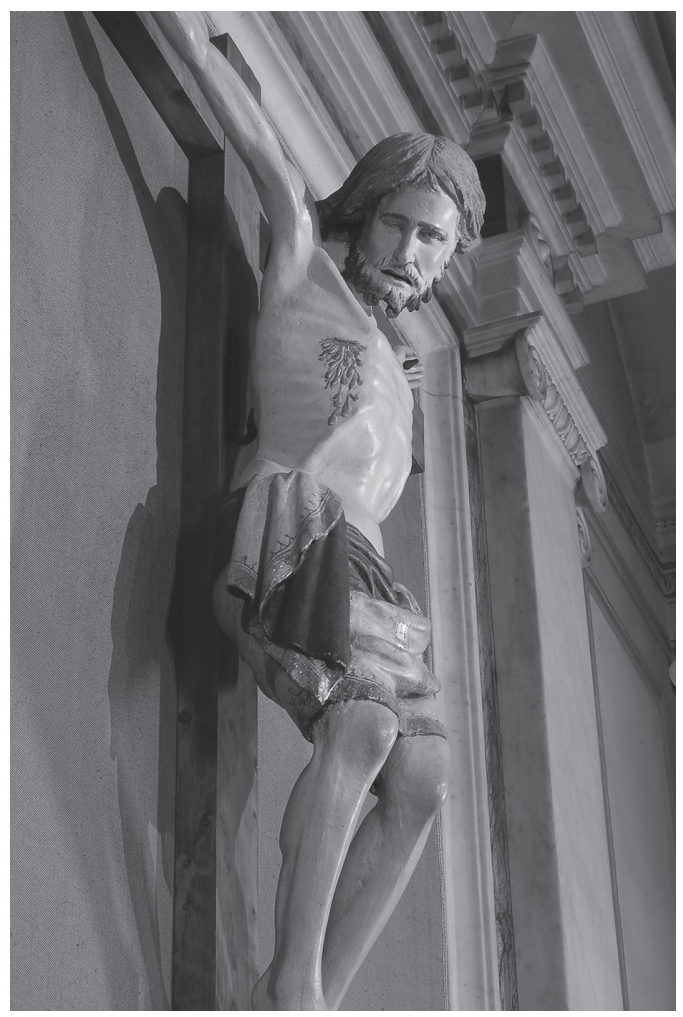

Figure 5.6 Detail of Figure 5.5.

serves to sustain attention around Christ's face and his side wound. We can speculate further about the liturgical circumstances that might lead a viewer to such a location and what kind of culturally specific response the dialogue might have elicited. ${ }^{44}$ But even without that knowledge we can still hear the call and, as with Rilke's torso, feel the agency of the object; its beauty 'still glows like a candelabrum' even if its force 'screwed back yet' - is dimmed across the gulf of history.

\section{Notes}

1 For the connection of the torso in the Louvre to Rilke's poem, see Ulrich Hausmann, Die Apollosonette Rilkes und ibre plastischen Urbilder (Berlin: Gebr. Mann, 1947). There are good circumstantial reasons for accepting this identification, but it would be reductive to say that the sonnet is entirely about the torso illustrated in Figure 5.1. Alongside Rodin's torsos as implied subject matter, it also responds to Winckelmann's famous description of the Belvedere Torso, and takes a torso-like poetic form as its medium.

2 Archaïscher Torso Apollos: Wir kannten nicht sein unerhörtes Haupt / darin die Augenäpfel reiften. Aber / sein Torso glüht noch wie ein Kandelaber, / in dem sein Schauen, nur züruckgeschraubt, // sich halt und glänzt. Sonst könnte nicht der Bug / der Brust dich blenden, und im leisen Drehen / der Lenden könnte nicht ein Lächeln gehen / zu jener Mitte, die die Zeugung trug. // Sonst stünde dieser Stein entstellt und kurz / unter der Schultern durchsichtigem Sturz / und flimmerte nicht so wie Raubtierfelle / und bräche nicht aus allen seinen Rändern / aus wie ein Stern: denn da ist keine Stelle, / die dich nicht sieht. Du mußt dein Leben ändern. 
Translation taken from Rainer Maria Rilke, Selected Poems with Parallel German Text, ed. Robert Vilain and trans. Susan Ranson and Marielle Sutherland (Oxford: Oxford University Press, 2011), 80-3.

3 Letters of Rainer Maria Rilke, 1892-1910, trans. Jane Bannard Greene and M. D. Herter Norton (New York: Norton, 1945), 191 [no. 88], Meudon, 15 September 1905 [alles ist voll der wunderbarsten Antiken, die mit seinen lieben Dingen verkehren als mit Verwandten, den einzigen, die sie haben, glücklich, wenn an ibren Leibern sich die tausand Augen aufschlagen, nicht ins Fremde zu schauen. Rainer Maria Rilke, Auguste Rodin: Der Briefwechsel und andere Dokumente zu Rilkes Begegnung mit Rodin, ed. Rätus Luck and trans. Rätus Luck and Heidrun Werner (Frankfurt a. M. and Leipzig: Insel, 2001), 108.

4 Rainer Maria Rilke, Rodin and Other Prose Pieces, trans. G. Craig Houston (London, Melbourne and New York: Quartet Books, 1986), 16. The imagery appears once more in the conversations between Rodin and Paul Gsell, published in 1911. Auguste Rodin, Art: Conversations with Paul Gsell, trans. Jacques de Caso and Patricia B. Sanders (Berkeley, Los Angeles and London: University of California Press, 1984), 10.

5 For a discussion, see 'Blickende Leiber, lebendige Farbe und die Krise der erotischen Kunst: Rilkes Sonett 'Archäischer Torso Apollos' im Kontext', in Hans Körner, Blickende Leiber, lebendige Farbe und Randfiguren in der Kunst: kunsthistorische Aufsätze (Berlin: Reimer, 2011), 97-107.

6 Wie sich nun an der Oberfläche des menschlichen Körpers im Gegensatze des tierischen überall das pulsierende Herz zeigt, in demselben Sinne ist von der Kunst zu behaupten, daß sie jede Gestalt an allen Punkten der sichtbaren Oberfläche zum Auge verwandle, welches der Sitz der Seele ist und den Geist zur Erscheinung bringt . . . so umgekehrt macht die Kunst jedes ihrer Gebilde zu einem tausend-ängigen Argus, damit die innere Seele und Geistigkeit an allen Punkten gesehen werde. Hegel's Aesthetics: Lectures on Fine Art, trans. T. M. Knox, 2 vols (Oxford: Oxford University Press, 1975), 153-4.

7 For a discussion see James Elkins (ed.), Art History versus Aesthetics (New York and London: Routledge, 2005).

8 Alfred Gell, 'The Technology of Enchantment and the Enchantment of Technology', in Alfred Gell, The Art of Anthropology: Essays and Diagrams, ed. Eric Hirsch (London and New Brunswick, NJ: Athlone Press, 1999), 159-86 (at 162). Originally published in Jeremy Coote and Anthony Shelton (eds), Anthropology, Art and Aesthetics (Oxford: Clarendon Press, 1992).

9 Gell, 'Technology', 161.

10 Gell, 'Technology', 160.

11 Alfred Gell, Art and Agency: An Anthropological Theory (Oxford: Oxford University Press, 1998), 1-11. See in particular the comments in the foreword by Nicholas Thomas (vii-viii).

12 For a discussion relevant to the argument of this chapter, see Alexander Nehamas, Only a Promise of Happiness: The Place of Beauty in a World of Art (Princeton, NJ and Oxford: Princeton University Press, 2007).

13 Alfred Gell, 'Vogel's Net: Traps as Artworks and Artworks as Traps', in Gell, Art of Anthropology, 187-214 (at 201): 'The trap may ... represent parameters of the animal's natural behaviour, which are subverted in order to entrap it.'

14 Any non-art historian following up this reference to Baxandall in the bibliography will be baffled by the book listed there: Radical Perspectives in the Arts by Lee Baxandall rather than Michael Baxandall's Painting and Experience (both published in 1972).

15 Gell, 'Technology', 162-3.

16 Gell, 'Technology', 162.

17 Gell, 'Technology', 162.

18 Gell, Art and Agency, 31.

19 Gell, Art and Agency, 31.

20 For a discussion relevant to the content of this chapter, see John Freccero, 'Medusa: the letter and the spirit', Yearbook of Italian Studies, 2 (1972), 1-18.

21 The Metamorphoses of Ovid, trans. Michael Simpson (Amherst, MA: University of Massachusetts Press, 2001), 54. For a discussion of the connection between Parmigianino's painting and Narcissus, see Norman E. Land, 'Parmigianino as Narcissus', Source, 16 (4) (1997), 25-30, and Christiane Kruse, 'Selbsterkenntnis als Medienerkenntnis: Narziß an der Quelle bei Alberti und Caravaggio', Marburger Jahrbuch für Kunstwissenschaft, 26 (1999), 99-116. 
22 Metamorphoses, 54.

23 Gell, 'Vogel's Net', 213.

24 For the detail of the argument presented here in relation to Dante, see Peter Dent, 'The Call of the Beautiful: Augustine and the Object of Desire in Purgatorio 10', in Desire in Dante and the Middle Ages, eds M. Gragnolati, E. Lombardi, F. Southerden and T. Kay (London: Legenda, 2012), 86-100. The text and translation used here is The Divine Comedy of Dante Alighieri: Purgatorio, ed. and trans. Robert Durling (Oxford: Oxford University Press, 2003).

25 Karlheinz Stierle, 'Das system der schönen Künste im "Purgatorio” von Dantes “Commedia”, in Stierle, Ästhetische Rationalität: Kunstwerk und Werkbegriff (Munich: Fink, 1997), 389-416.

26 For the evidence, see Dent, 'Augustine'. The section quoted here comes from section 10.6.9. The translation is taken from Saint Augustine, Confessions, ed. and trans. Henry Chadwick (Oxford: Oxford University Press, 1991).

27 The idea of beauty as a call ultimately depends upon an etymology advanced in ancient Greece that linked the word for beauty with the verb 'to call'. This etymology was transmitted to the medieval West in The Divine Names by Pseudo-Dionysius and figures in various late medieval commentaries on this text by theologians such as Albert the Great and Aquinas. See the discussion in Dent, 'Augustine', and the fundamental study by Jean-Louis Chrétien, The Call and the Response, trans. Anne A. Davenport (New York: Fordham University Press, 2004). See also note 31 below.

28 Mary Carruthers, The Experience of Beauty in the Middle Ages (Oxford: Oxford University Press, 2013).

29 Carruthers, Experience of Beauty, 15.

30 The key concept advanced by Carruthers in this regard is ductus: 'Ductus is the way by which a work leads someone through itself: that quality in a work's stylistic patterns which engages an audience and then sets a viewer or auditor or performer in motion within its guiding structures and articulating colours, an experience more like travelling through stages along a route than like perceiving a whole object.' See Mary Carruthers, 'The Concept of Ductus, or, Journeying through a Work of Art', in Rhetoric Beyond Words: Delight and Persuasion in the Arts of the Middle Ages, ed. Mary Carruthers (Cambridge: Cambridge University Press, 2010), 190. Following Carruthers, some art historians have already applied the idea. See, for example, Paul Crossley, 'Ductus and Memoria: Chartres Cathedral and the Workings of Rhetoric', in Carruthers, Rhetoric Beyond Words, 214-49.

31 From this perspective, Carruthers talks suggestively of objects having 'faces' and 'voices' and, indeed, analyses some texts that involve 'speaking' images, of which The Dream of the Rood is the most relevant here. However, the tradition of connecting voice and beauty that underpins the elision found in Augustine (see in particular note 27 above) does not form part of her argument. Indeed, a recent review of Carruthers' book expresses surprise that precisely this connection is lacking. See Ann W. Astell in Renaissance Quarterly, 69 (3) (2016), 1185-6:

One standard definition of beauty, 'beauty is a relation,' bridges the beholder and the beheld as reciprocal termini. It builds upon a key etymology that Carruthers, who delights in profuse and instructive etymologizing throughout the book, does not mention: namely, that which links the Greek adjective kalon, meaning 'beautiful,' with the Greek verb kalein, which means both to 'call out' and to 'name.' Fortunately, Carruthers's own practice throughout the book enacts this relation.

32 For a general overview of this paradox, see Richard Viladesau, The Beauty of the Cross: The Passion of Christ in Theology and the Arts - From the Catacombs to the Eve of the Renaissance (Oxford and New York: Oxford University Press, 2006), 9-12 but throughout.

33 For a discussion of a fourteenth-century Planctus from Cividale where this appears to be the case, see Laura Jacobus, "Flete mecum": The Representation of the Lamentation in Italian Romanesque Art and Drama,' Word and Image, 12 (1) (1996), 110-26.

34 See, for example, Ulrich Kuder, 'Mittelalterlicher Bildgebrauch: Überlegungen zum ersten Blatt eines Psalters aus der Zeit um 1200,' in Die Schönheit des Sichtbaren und Hörbaren: Festschrift für Norbert Knopp zum 65. Geburtstag, ed. Matthias Bunger (Wolnzach: Kastner, 2001), 61-85.

35 The episode is discussed in Elvio Lunghi, La Passione degli Umbri: Crocifissi di legno in Valle Umbra tra Medioevo e Rinascimento (Foligno: Orfini Numeister, 2000), 39-50. 
36 For an extensive discussion of Christ's body as a book, see Peter Dent, 'A Window for the Pain: Surface, Interiority and Christ's Flagellated Skin in Late Medieval Sculpture', in Flaying in the Pre-modern World: Practice and Representation, ed. Larissa Tracy (Martlesham and Rochester: Boydell \& Brewer, 2017), 208-39.

37 The Cividale Planctus mentioned above in note 33 has Mary speak Lamentations 1:12 ('o vos omnes'), for example.

38 For a discussion of speaking wounds in the context of sculpted crucifixes, see Dent, 'Window'.

39 See Alessandro Bagnoli (ed.) Marco Romano e il contesto artistico senese fra la fine del Duecento e gli inizi del Trecento (Milan: Silvana, 2010), 176-081 (cat. no. 7).

40 For example, in Lo Specchio della Croce, Domenico Cavalca (d.1342) described Christ on the cross as 'a book, in which is condensed the whole of scripture; and in which every person, inexperienced or ignorant, can openly read every perfect doctrine.' See Dent, 'Window', $228-9$.

41 See Stefano D'Ovidio, Scultura lignea del medioevo a Napoli e in Campania (Naples: Società napoletana di storia patria, 2013), 182-5 (cat. no. 13).

42 For which see Max Seidel “'Sculpens in ligno splendida”: sculture lignee di Giovanni Pisano', in Scultura lignea a Pisa dal XII al XV secolo, ed. Mariagiulia Burresi (Milan: Federico Motta, 2000), 90-2.

43 As Carruthers suggests, 'In the presence of any artefact, our first question could then be not 'What is it (and what does it represent)?' but 'What is it doing (and what is it asking us to do)?' Carruthers, Experience of Beauty, 14.

44 The Adoration of the Cross would be the obvious liturgical 'path' around and through these works that would take a viewer from distance to proximity in such a way that the formal properties identified here would emerge naturally during the encounter. 

Part 3

Objects as Social Agents 



\title{
6 Dispersal, Exchange and the Culture of Things in Fifteenth-century Italy
}

\author{
Leah R. Clark
}

'My owner is Cardinal Pietro Barbo, Venetian and generous scholar; your priest and

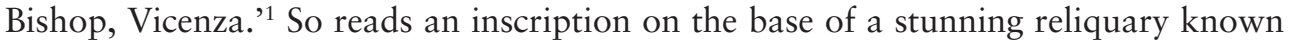
as the Montalto Reliquary, once belonging to Pietro Barbo (later Pope Paul II) and still visible today on the fascinating object now housed in the Museo Diocesano in Montalto delle Marche (Figure 6.1). Adorned with precious jewels such as sapphires and rubies and crafted out of beautiful enamel and metalwork, we are fortunate to still have such a remarkable piece of goldsmith work, as so many similar precious collectibles faced the eager melting pot when purse strings got tight. The inscription points to the agency of the object, an attempt to give voice to the inanimate thing before us, proudly telling us of its owner, to become what Lorraine Daston has termed a 'loquacious thing'. ${ }^{2}$ This extraordinary work has also caused much ink to be spilled as it was meticulously described in a number of inventories, allowing us to trace its biography as it moved through numerous hands: from Charles V to Frederick IV of Tyrol to a German merchant who sold it to Leonello d'Este Marquis of Ferrara to Barbo and finally to Sixtus V who donated it to the Montalto delle Marche in 1586, adding an inscription and arms to record his final ownership. ${ }^{3}$

Such a fascinating object raises a number of concerns around the paradox of precious things in the fifteenth century as their value led to their circulation and dispersal yet individuals attempted to record their temporary ownership through inscriptions, arms and other identifiers. The inventories recording these objects allow us to trace their provenances, but these documents should not be seen as a means to an end, rather they highlight multifaceted approaches to people's possessions and underscore the very transient existence of many early modern things. Traditional Art History has largely concentrated on the production and consumption of art works rather than their destruction and thus inventories and account books have often been examined with a focus on the acquisition rather than the dispersal of possessions. A closer look at account books, inventories and other documents, as this chapter will argue, reveals a more complex cycle in which works were made, destroyed, purchased, loaned, exchanged, pawned and melted.

\section{Inventories and the (Dis)order of Things}

Recent approaches to inventories have reconsidered their function and begun to approach them not as transparent documents but social agents, which shaped a culture around cataloguing and ordering objects. ${ }^{4}$ Pietro Barbo's inventory written by different compilers between 1457 and the early 1460s reflects the ongoing and shifting 


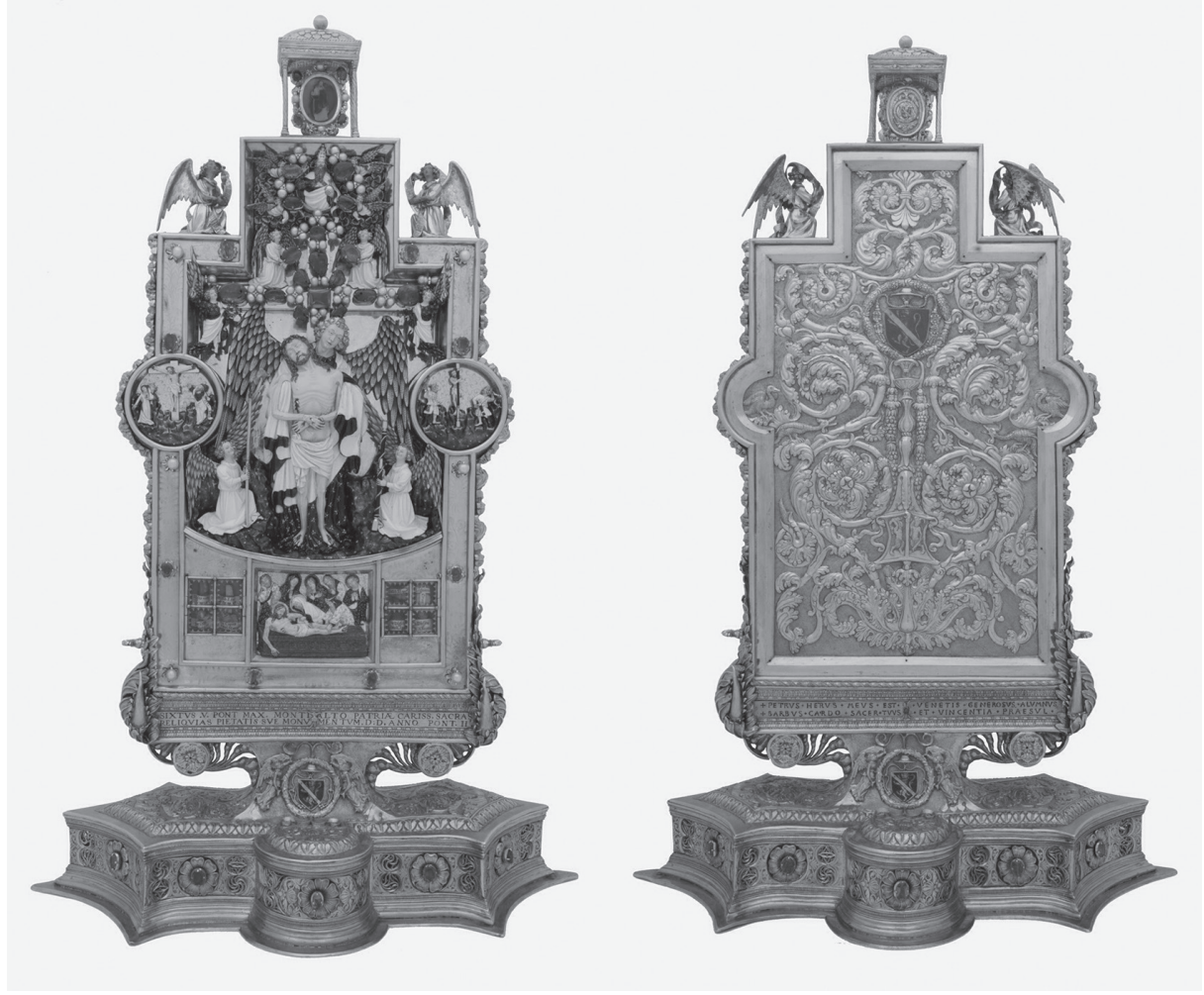

Figure 6.1 Montalto Reliquary, front and back with inscriptions. Montalto delle Marche, Museo Diocesano.

status of the objects recorded; like many fifteenth-century inventories, pages were left blank to be added to when new works were purchased or when objects were dispersed or destroyed. As Xavier Salomon has rightfully noted, such an inventory must be seen as a work in progress, demonstrated by the 1460 additions, which reveal that eight objects had been sold, 68 had been melted down, while others were given away as presents. ${ }^{5}$

Similar examples are found in the archives in Modena, where the records of the Este, rulers of the court of Ferrara, are kept. Looking closely at these books as things as well as books of things opens up new avenues to pursue the agency of things in the Renaissance. An account book belonging to Eleonora d'Aragona, Duchess of Ferrara (catalogued as AP 638), details many items in Eleonora's ownership and is less an inventory than an ongoing record of the movement of objects in her possession; itself a mobile object that traces the movement of other objects. ${ }^{6}$ The book records goods in the Duchess's household for the years 1478-85, keeping tabs on items, from silverware to mirrors and from tapestries to books. Objects' provenances are dutifully noted, particularly in the case of gifts, but items are also recorded as pawned, borrowed or stolen, contributing to our understanding of the social lives of things therein. ${ }^{7}$

Under most items there are entries in different pens from different years that announce the particular object's movements (Figure 6.2). The account book thus gives us insight 


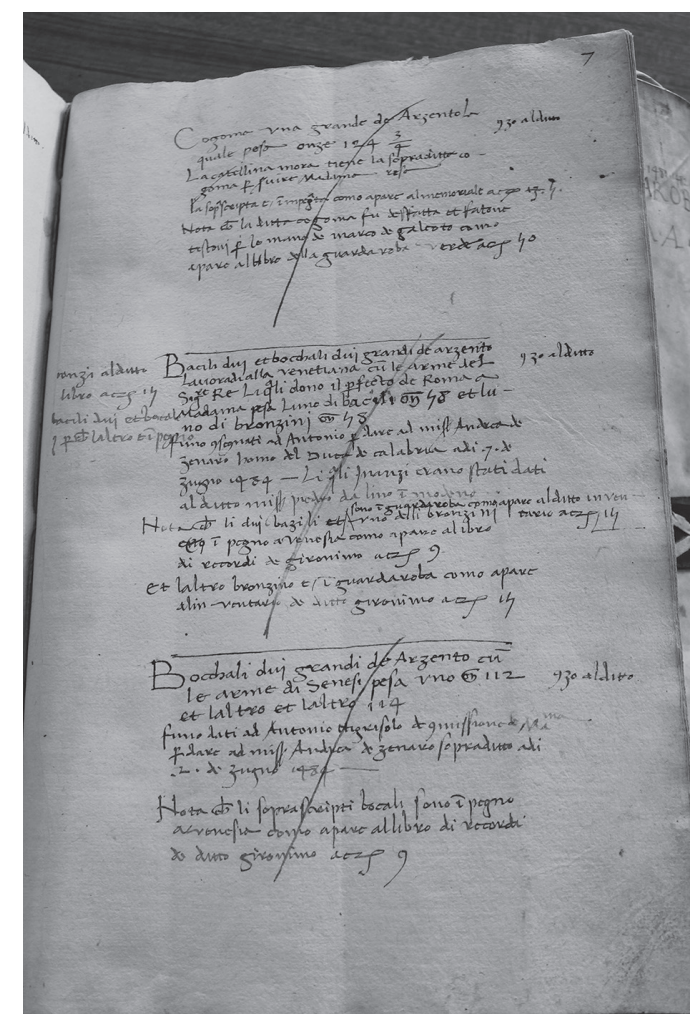

Figure 6.2 Entry from Archivio di Stato di Modena, Amministrazione dei Principi. Archivio di Stato di Modena, 638 7R.

into the life stories of specific objects, from 'elephant teeth' (tusks) that were cut in half and distributed between Eleonora's children to silver ewers that were used by visitors, but then later melted and pawned. ${ }^{8}$ The book was thus largely dedicated to moveable goods: things that were lent out to Eleonora's staff; items used in rooms when visitors came to stay; religious objects which were used according to the liturgical calendar in the chapel; cloth that was remade into something else; books that were moved and lent; silver that was pawned; and tapestries that were moved from room to room.

On the cover of this particular account book the compiler has scribbled a memento mori message: pensi la morte tua ('think of your death') (Figure 6.3). The writing of such an inventory may have led those compiling it to think of the issues at stake in collecting and the contradictory status objects held in this time period: on the one hand, they were symbolic goods reflecting magnificence and operating as repositories of knowledge, while on the other hand they were often used as liquid capital, functioning as pawns for loans. The objects recorded within such books were sociable things in their intended uses, but also in terms of the people who maintained them, recorded them in inventories or account books and those who handled them during their movement. There were numerous ways in which things circulated between individuals in the fifteenth century, but this chapter will be attentive to two main means of movement: loaning and pawning. 


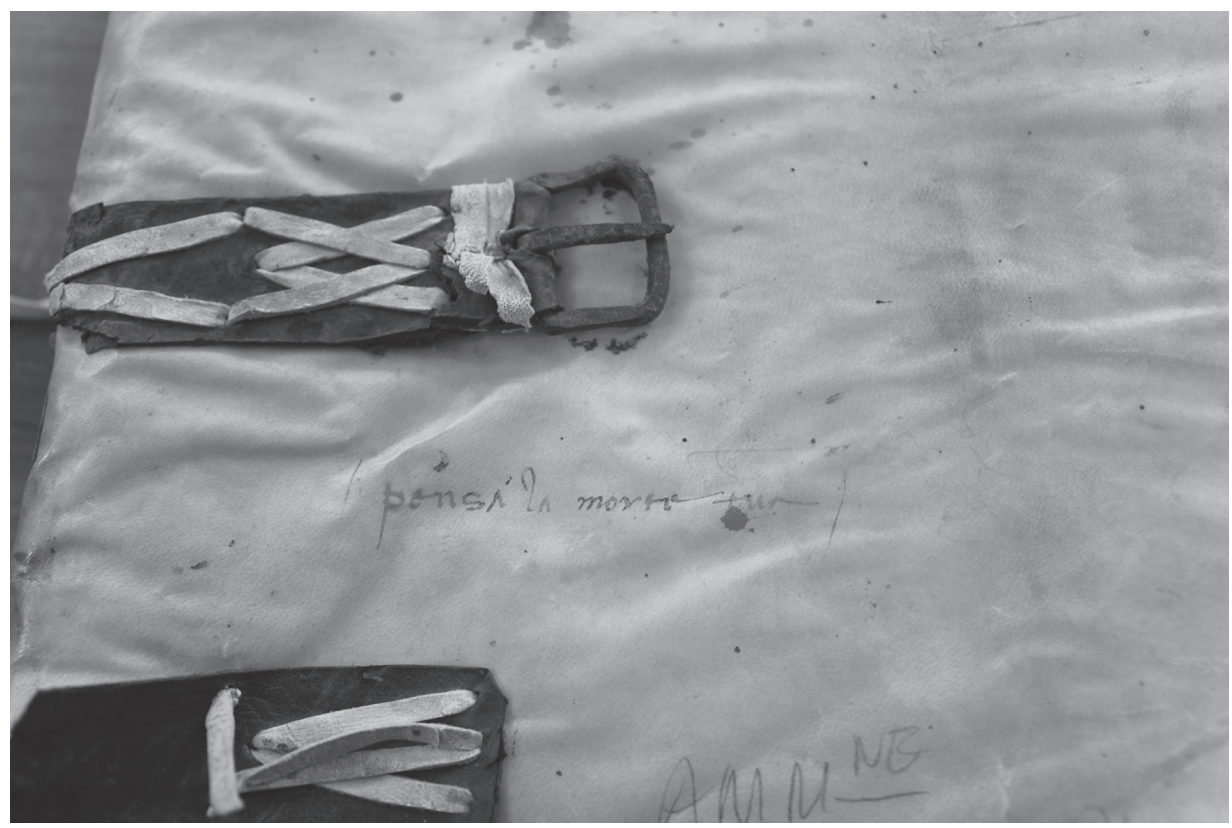

Figure 6.3 Detail of memento mori message on cover of Archivio di Stato di Modena, Amministrazione dei Principi. Archivio di Stato di Modena, 638.

\section{Loaning, Stealing and the Borrowing of Status}

In the Renaissance, objects could be used as collateral and were consequently pawned or given as credit, but unlike money, objects were and are absorbent of meaning and memories, thus not only forging bonds between those who come in contact with them, but also bringing about hostilities and complications. Early modern objects should be seen as stores of value, whereby most items - from handkerchiefs to jewels to books could be offered as pledges but the value of objects was not only monetary and many objects carried conflicting identities, comprising economic as well as cultural value. ${ }^{9}$ Since magnificence, liberality and splendour were underlying themes of cultural display and consumption during this time, individuals were more prone to invest any cash they might have in cultural objects, which could then be pawned or put up for credit when needed. ${ }^{10}$ The liquid potential of objects, however, placed a precariousness on their very possession, an anxiety that can be identified through the use of marks of ownership on many objects.

The need to display wealth during stately visits or feasts gave rise to the practice of credenze, pieces of furniture made specifically to display precious vessels. ${ }^{11}$ Such displays, however, did not necessarily reflect accurately the possession of wealth but rather pointed to the networks one had to borrow from, something that did not go unnoticed by attendees, as one primary source attests:

I found that, in the year of 1467 at the marriage of Niccolo Martelli, and at a supper which the knight messer Antonio Ridolfo gave to the Duke of Calabria ... at a banquet given by Giovanni Aldobandini and at others given by men equal to 
these citizens of mark and by no means of lean purse, as well as on other occasions of sitting down together, the same silver appeared, being lent round by the same circle of friends. ${ }^{12}$

In Republican Florence, the Medici recorded numerous instances of lending out silver plate, as well as books and even paintings. While the reasons varied, many of these loans seem to have been related to diplomacy, when foreign ambassadors visited Florence, and the Medici were thus acting as de facto rulers ensuring the value of their plate would reflect the magnificence of their city. For instance, on 27 May 1483 twelve cups of silver taken from the Medici scriptoio were sent to Cafaggiolo for the reception of the Turkish ambassador who was en route to the Count of Savoy. ${ }^{13}$ Jewellery was sometimes also lent between families, such as in 1483 when Antonio Strozzi borrowed a necklace for his 'contracted bride ... for a month or two, as if he had bought it for her himself. ${ }^{14}$

The Florentine Giovanni Chellini was also recorded as possessing much silver plate and was known for his continual lending of it to fellow citizens who 'were taking up office or celebrating a wedding'. He is recorded lending 'six silver dishes to Neri Capponi when he was sent as ambassador to Milan'. Soon afterwards he lent Giovanni Lorini, who had been recently made captain of a galley going to Sicily, 'a silver jug with gilded foliage inside and blue enamelling at the bottom, six silver cups, and four silver trenchers or dishes'. ${ }^{15}$ Only six months later he is recorded lending almost exactly the same items to Lorini again when he was being sent as a vicar to San Miniato. Aside from ambassadors and captains who likely needed these items for political reasons in terms of their employment, such items also had more personal uses at important stages in one's life, as when Bernardo di Cristofano Carnesecchi borrowed plate from Chellini for the wedding of one of his daughters.

Private concerns such as family honour and public reputation in terms of economic or business standing were not mutually exclusive of course, and feasts were times when these two identities were on show, reflected in things like the plate adorning the credenza or jewellery adorning the bride. The lending of objects by Chellini also contributes to our understanding of how objects constituted bonds between individuals and contributed to what Patricia Rubin has termed the 'economy of honour' in Renaissance Florence. ${ }^{16}$ Chellini's business dealings as a doctor underline that he understood that objects could serve purposes that went beyond monetary value, carrying symbolic, cultural and artistic value that served to constitute not only material exchanges but moral and symbolic ones. For example, Chellini received cloth and other items in return for his professional services, including a gilt bronze roundel of the Virgin and Child by none other than Donatello. Similarly, Cardinal Carlo Forteguerri paid his doctor not in money but instead gifted twelve silver spoons and a silver cloth woven with figures in gold for treating the Cardinal's illness that lasted 75 days. The type of social bonds elicited by such a transaction is revealed in the physician's ricordanza, which states that the Cardinal 'was not giving them to me in payment, because he knew that I would not have accepted them, but in memory of our long, firm friendship.' 17

Outside the Republic of Florence, borrowing was also common between court rulers and should be considered along the same lines as gifting, whereby such acts were often part of diplomacy and were indicators of poor or good relations. Loaning one's precious items to another ruler required trust. In January 1491, for example, 
Ercole d'Este wrote to Caterina Sforza, the ruler of Forlì about silver and tapestries he wanted to borrow for the wedding of his son, Alfonso d'Este. ${ }^{18}$ Numerous letters attest to Francesco II Gonzaga seeking to borrow tapestries and silver vases from a variety of individuals including the Duke of Urbino, the ruler of Carpi and Giovanni Bentivoglio of Bologna. ${ }^{19}$ Tapestries, as is well known, were mobile pieces that could easily be moved from room to room or palace to palace, but this meant that they could also be easily stolen. In 1483 the Duke of Calabria's retinue staying in Ferrara actually lifted the hangings that had adorned their suite, and tapestries are also recorded going missing in 1478 and $1499 .{ }^{20}$ Tapestries were also easily altered such as those the Este bought from Drusiana Sforza, where the arms associated with the Visconti were replaced with those of the Este. ${ }^{21}$

The desire to copy or emulate another ruler's dining service is evident in the case of Ludovico Sforza of Milan who requested drawings of Ercole d'Este's famous service. Ludovico was told, however, that he would have to wait two years as the service had been pawned in Florence, underlining the transient nature of such precious pieces. ${ }^{22}$ Prominent names attached to designs of services sometimes helped to dissuade their destruction, but not always. When the Duke of Urbino, Francesco Maria della Rovere, was required to melt down his silver after being defeated in battle by Pope Leo X, his wife and mother tried to ensure two pieces be saved, which were described as 'very beautiful in their design and [in] the antique mode, designed by Raphael'. ${ }^{23}$

The ability to bring one's own argenti di parata (banquet plate) when travelling without having to borrow from others was a status symbol in itself. When Lorenzo de' Medici went to meet the new pope Sixtus IV in 1471, he travelled with his own silverware, a magnificent site to witness, as recorded by Giusto d'Anghiari in his Ricordi:

Among the other ambassadors, the magnificent Lorenzo de' Medici came with much splendor. He brought 35 horses and seven mules carrying about 400 pounds of silverware, which I saw by myself when they were about to be packed - basins, platters, bowls, and plates and other types of silver vessels. It was a fine send-off to see. ${ }^{24}$

Pietro Barbo's inventory attests to his economic ability to be accompanied by his own plate. On 12 September 1460 in Siena, two sheets of paper were added to his inventory, which recorded a list of 170 silver objects from Barbo's credenza, which he had taken with him during his travels between Mantua and Rome. Not only does this attest to Barbo's economic status, but it also points to the ways that such documents were live and active pieces of information that accompanied the things they described and their owners as they moved from place to place. It also underlines that those who compiled these documents were also on the move, escorting the objects and ensuring that their safety and location were continuously watched and recorded.

The circulation of service was closely regulated, as is evidenced by sixteenthcentury texts from the courts of Mantua, Ferrara and Urbino, which detail the procedures around handling, using, storing and tracking these items. ${ }^{25}$ Fear of theft is evident in these texts, as an example from the court of Mantua stated specifically that if any plate is found in the hands of someone without the licence or consent of the 'persons in charge of these objects' they will be punished. ${ }^{26}$ Such regulations, however, seem to have done little to dissuade nimble fingers as banquet plate is often recorded going missing. 


\section{Pawning, Credit and the Transiency of Possessions}

Credit was a common custom in the early modern period and many transactions were conducted with a promise to pay, or with a credit secured with one's belongings, often an object of similar value used as a pledge. ${ }^{27}$ Pawning was also a widespread activity across all social scales, from the pawning of clothing or hammers to the pawning of jewels and court libraries. Much of the nobility across Italy pledged their jewels as security for loans but individuals who could not repay their loans lost a certain respectability and also often lost their ability to borrow, branded as uncreditworthy.

The pawning of jewels offers useful examples to explore how jewellery acted as social and cultural signifiers for both men and women. Jewels held monetary value, but equally were celebrated for their personal characteristics. ${ }^{28}$ Worn on the body, they manifested the physical and visible forms of credit, while also conveying more symbolic forms of identity linked to honour and prestige. ${ }^{29}$ The significance of jewels in court life is often underlined in ambassadorial reports such as that written in September 1479 by Paulo Antonio Trotti, the Ferrarese ambassador, addressed to Eleonora d'Aragona regarding his visit with Duke Gian Galeazzo Maria Sforza of Milan. Trotti took note of the Duke of Milan's necklace, describing it as a ruby 'which was the [jewel] called ils spigo once belonging to Re Alfonso [I d'Aragona], which is the most beautiful thing I have seen.' ${ }^{30}$ The jewel, as was common in the fifteenth century, is given a name - il spigo - underlining its individuality, allowing it to become personalised through this naming process. ${ }^{31}$ This naming contributed to the jewel's social biography and the making of identities - both of the owner and the jewel. Furthermore, Alfonso I was Eleonora's grandfather and such a jewel was thereby charged with memories of lineage. Il spigo was later pawned by Ludovico Sforza in the late 1490s estimated at 25,000 ducats along with other precious jewels which were named: Il Lupo, La Sempreviva and El Buratto. ${ }^{32}$ The names given to these jewels could derive from the visual properties of the stones as spigo, for instance, is the Italian for lavender, while buratto is a type of lace. Sforza's La Sempreviva took the form of the sempervivum, a hardy plant, presumably carrying with it the idea of imperial immortality or longevity. ${ }^{33}$

Merchant account books reveal the circulation and change of ownership of pawned jewels. For instance, on 26 September 1487, pawned jewels were sent from Florence with Francesco Valori, ambassador of Florence, to Naples for the Strozzi Bank. The list of jewels included a large ruby, an emerald, a brooch and Il Davit, described as a pendant balas (ruby-coloured spinel) set in gold with pearls and placed on a gold chain. ${ }^{34}$ Il Davit had been used as a pledge three years earlier by King Ferrante of Naples and was thus in Filippo Strozzi's possession for three years. Loans and pawning were also clearly linked to trade relations, and merchants would often receive concessions on customs duties as payment. In 1475 the Strozzi Company sold a balas, which was set with three large pearls, two diamonds and an emerald to the king for 700 ducats in exchange for extracting an equivalent sum in salt out of Puglia. ${ }^{35}$ Similarly, in 1477 King Ferrante offered to waive the customs dues in the exportation of foodstuffs from the kingdom of Naples in order to meet the 964 ducats he owed to the Medici bank in Naples. ${ }^{36}$

Particularly intriguing are the ways jewels were pawned and then returned for a few days to serve a purpose. For instance, Ippolita Sforza, Duchess of Calabria, pawned a ruby to Gabriello di Soldo Strozzi, but she had her treasurer Luigi Gattola ask for it 
back on 26 January 1488, with a promise that she would return it in five days, so that she could wear it for a special feast. ${ }^{37}$ Similarly, Duke Ercole d'Este of Ferrara pawned his most-treasured and famous triangolare, an enormous diamond, to the Gondi, with a half-pawn also consigned to the Medici, during Ferrara's war with Venice. When he wanted the diamond returned to him for a week so he could wear it to the wedding celebrations of his daughter Isabella d'Este and Francesco Gonzaga, Ercole promised all the revenue of the salt mines of Commachio for a period of ten years. ${ }^{38}$

Jewels could be plucked from the elaborate gowns they once adorned at times of death or financial difficulty, such as in 1468 when Milanese goldsmiths were in charge of removing the rubies from Bianca Maria Sforza's clothing after her death in order to create new jewellery. ${ }^{39}$ Pietro Barbo's inventory records a number of objects pawned to the Baroncelli bank, including a jewel in the shape of an ostrich, a salt-cellar encrusted with jewels and three large oriental pearls. ${ }^{40}$ Barbo was not alone, as cardinals frequently accrued debt since their courtly lifestyles did not match their incomes, resulting in a large quantity of antiquities and valuable goods to be continuously pawned. ${ }^{41}$

Pawning and pledging also reflected the volatility of political regimes and the fall of influential families. The Medici's famous balas brooch nicknamed Il Libro was first mentioned in the 1464 inventory of Piero il Gottoso valued at 5,000 florins. It was prized and worn by Lorenzo but was also sported on the body of his brother Giuliano at the joust in 1475. When the Medici fell from favour in 1494 and were expelled, it was pawned by Piero lo Sfortunato along with 'twenty silver plates, a silver mirror and a jasper tondo containing 176 cameos and precious stones' to the banker Agostino Chigi. ${ }^{42}$

Warfare could often lead ruling families to pawn their libraries and jewels to foot the bill, and when their coffers were empty and they could not afford to pay their army, soldiers would have to find ways of funding their existence, often in foreign territory. This is reflected in documents in the Archivio della Fabbrica del Duomo in Milan which record loans sought from Milanese and Bolognese lawyers by German mercenary captains, but evidence across Italy attests to the necessity of soldiers having to pawn arms and goods at local taverns and inns to pay their way. ${ }^{43}$

The circulation of objects through practices such as pawning gave rise to interests in provenance. Objects with interesting biographies and those that brought with them histories of illustrious ownership were thus even more valuable and sought after, but purchasing an object once owned by another ruler could prove contentious, and acquisition was often political. For example, Francesco Sforza asked to purchase jewels that had been pawned by Duke Federigo da Montefeltro of Urbino for 4,000 gold ducats, because Federigo could not repay the loan and Francesco wanted to avoid the jewels going on the open market. ${ }^{44}$ The complicated processes of pawning within the same bank is exemplified by the inability of Lorenzo de' Medici and his clients such as Matthias Corvinus to obtain the highly sought-after gems belonging to Cardinal Francesco Gonzaga on credit with the Medici Bank because they were under the jurisdiction of Giovanni Tornabuoni not Lorenzo. ${ }^{45}$ During the sale of the Medici goods in the 1490s following their expulsion, Ludovico Sforza wrote to his ambassador to see what objects he could acquire. Not long after, however, Ludovico himself would have to pawn his own goods in 1499 when negotiations with the French led to his downfall. ${ }^{46}$ The Medici sale included not only famous antiquities, but also more personal items, including Lorenzo de' Medici's birth salver, that no doubt held familial memory and symbolic value. ${ }^{47}$ The sale was mentioned three times in the pharmacist 
Luca Landucci's Zibaldone, leading him to comment on the transient nature of life on earth and worldly power and the extent of God's wrath. ${ }^{48}$

The practice of asserting possession through arms or initials on objects demonstrates a need to control the very transient ownership of those collectibles. The 'speaking' inscription on the Montalto Reliquary is only one example of how collectors sought to demonstrate their ownership. Pietro Barbo also asserted claims over his possessions by ensuring his arms were displayed on tapestries, metalwork, rings, handkerchiefs, candlesticks, boxes, cups and plates, while the cameos in his collection were displayed on trays with arms on the front and inscriptions on their backs. ${ }^{49}$ Lorenzo de' Medici's well-known practice of engraving his gems and hardstones with 'LAV.R.MED.' also alludes to the ways in which possession of these antiquities had become something linked to one's identity. ${ }^{50}$ The tradition of naming jewels and the obsessive addition of arms, initials or other means of identification onto these objects points to the very anxiety towards possessions. These habits attempted to conceal both the owners' economic instability and the jewel's status as a commodity.

While many objects changed hands when money got tight, some were not so fortunate and were destroyed. This particular fate is underlined in a sensational passage by Lorenzo Ghiberti, when discussing the work of a goldsmith named Gusmin, who 'saw his work [a golden altar] undone that he had made with such love and art, for the Duke [of Anjou]'s public needs; he saw his labor had been vain.' This, Ghiberti tells us, caused him to abandon his career as an artist and live as a 'penitent for the rest of his life'. ${ }^{11}$ This passage and the story of this work's destruction continued into the sixteenth century as it was elaborated upon in the anonymous Magliabecchiano, underlining that the interest in the fates of objects (and the practice of destroying works because of economic need) was still ever present two centuries later.

Objects brought numerous people together in diverse ways through their mobility; they also constantly circulated in and out of the commodity sphere. By examining a variety of objects that circulated through diverse forms of exchange, this study has highlighted the ways that objects could be used as capital, but they were also residual. Objects are absorbent and receptive things; with each transaction, something of the social sticks to them. Webb Keane has underlined the 'bundling' quality of objects, as they are always bound up with other qualities, associations and correspondences, and 'these qualities together in any object will shift in their relative salience, value, utility and relevance across contexts. ${ }^{52}$ But if we understand that many luxury objects in the late fifteenth century circulated as commodities at one point or another in their lifetime, we should, however, not be so quick to assume that these objects were merely neutral monetary commodities. Instead, the names given and the arms and initials inscribed onto them suggest a need to individualise them. Such objects functioned as agents in court culture, as well as in larger fifteenth-century politics and economics on the Italian peninsula, forging bonds, but just as equally creating rifts and operating as sites of political tension.

\section{Notes}

1 'PETRVS. HERVS. MEVS. EST. VENETIS. GENEROSVS. ALVMNVS +BARBVS. CARDO. SACER. TVVS. ET. VICENTIA. PRAESVL'. Quoted and translated in Xavier F. Salomon, 'Cardinal Pietro Barbo's Collection and its Inventory Reconsidered', Journal of the History of Collections, 15 (1) (2003), 11. Also see Filippo Trevisani, 'Il Reliquiario di Montalto', in Le Arti nelle Marche al tempo di Sisto V, ed. Paolo Dal Poggetto, Rilquairio Montalto (Milan: Silvana, 1992), 46-56. 
2 Lorraine Daston, 'Introduction. Speechless', in Things That Talk: Object Lessons From Art and Science, ed. Lorraine Daston (New York: Zone Books, 2004), 9-24. Of course such an inscription also highlights the need for human actors to make such objects speak, one of the critiques of object oriented ontologies, see Shannon Gayk and Robyn Malo, 'The Sacred Object', Journal of Medieval and Early Modern Studies, 44 (3) (2014), 460-1. Lena Cowen Orlin, 'Empty Vessels', in Everyday Objects: Medieval and Early Modern Material Culture and Its Meanings, eds Tara Hamling and Catherine Richardson (Farnham and Burlington, VT: Ashgate, 2010).

3 For the reliquary in Paul II's inventory see Salomon, 'Barbo's Collection', especially 11. For the entire transcription of his inventory see Eugène Müntz, Les Arts à la cour des papes Innocent VIII, Alexandre VI, Pie III, 1484-1503 (Paris: E. Thorin, 1898).

4 Giorgio Riello, 'Things Seen and Unseen: The Material Culture of Early Modern Inventories and Their Representation of Domestic Interiors', in Early Modern Things: Objects and Their Histories, 1500-1800, ed. Paula Findlen (Abingdon and New York: Routledge, 2013), 125-50. Francesco Freddolini and Anne Helmreich, 'Inventories, Catalogues and Art Historiography: Exploring Lists Against the Grain', Journal of Art Historiography, 11 (2014), 1-14. Lia Markey and Jessica Keating, 'Introduction: Captured Objects. Inventories of Early Modern Collections', Journal of the History of Collections, 23 (2) (2010), 283-300. Katherine Anne Wilson, 'The Household Inventory as Urban "Theatre” in Late Medieval Burgundy', Social History, 40 (3) (2015), 335-59.

5 Salomon, 'Barbo's Collection', 3.

6 Archivio di Stato di Modena (ASMO), Amministrazione dei Principi (AP) 638.

7 Arjun Appadurai (ed.) The Social Life of Things: Commodities in Cultural Perspective (Cambridge: Cambridge University Press, 1986).

8 Such examples are numerous throughout the book. See ASMO AP 638, specifically 7R; 101R; 31 R.

9 Evelyn S. Welch, Shopping in the Renaissance: Consumer Cultures in Italy, 1400-1600 (New Haven, CT and London: Yale University Press, 2005), 196; Evelyn S. Welch, 'From Retail to Resale: Artistic Value and the Second-Hand Market in Italy (1400-1550)', in The Art Market In Italy. 15th-17th Centuries/Il mercato dell'arte in Italia secc. XV-XVII, eds Marcello Fantoni, Louisa C. Matthew and Sara F. Matthews-Grieco (Ferrara: Franco Cosimo Panini Editore, 2003); Frederic C. Lane and Reinhold C. Mueller, Money and Banking in Medieval and Renaissance Venice. Coins and Moneys of Account, vol. I (Baltimore, MD and London: Johns Hopkins University Press, 1985), 75-8.

10 Guido Guerzoni, 'Liberalitas, Magnificentia, Splendor: The Classic Origins of Italian Renaissance Lifestyles', in Economic Engagements with Art, eds Neil De Marchi and Craufurd D. W. Goodwin (Durham, NC and London: Duke University Press, 1999).

11 For the credenza see Peter Thornton, The Italian Renaissance Interior. 1400-1600 (New York: Harry N. Abrams, 1991), 205-7, 220-2; Valerie Taylor, 'Banquet Plate and Renaissance Culture: A Day in the Life', Renaissance Studies, 19 (5) (2005), 621-33.

12 Quoted in Luke Syson and Dora Thornton, Objects of Virtue: Art in Renaissance Italy (Los Angeles: J. Paul Getty Museum Publications, 2001), 68.

13 These were returned on 31 May 1483. Marcello Del Piazzo (ed.) Protocolli del carteggio di Lorenzo il Magnifico, per gli anni 1473-74, 1477-92 (Florence: L. S. Olschki, 1956), 445.

14 Quoted in Syson and Thornton, Objects of Virtue, 42.

15 From a seventeenth-century copy of a manuscript recording Chellini's family written by Scipione Ammirato il Vecchio, in the Biblioteca Nazionale, Florence (Passerini MSS. 191, no. 38). Quoted and translated in Ronald Lightbown, 'Giovanni Chellini, Donatello, and Antonio Rossellino', Burlington Magazine, 104 (708) (1962), 103.

16 Patricia Lee Rubin, Images and Identity in Fifteenth-Century Florence (New Haven, CT and London: Yale University Press, 2007), chapter 3.

17 Quoted in Rubin, Images and Identity, 60. Also see Lightbown, 'Chellini', 104.

18 ASMO Carteggio Principi Esteri (CPE) 1177, letter of 5 January 1491.

19 Giancarlo Malacarne, Sulla mensa del principe: alimentazione e banchetti alla corte dei Gonzaga (Modena: il Bulino, 2000), 55-6.

20 Thomas Tuohy, Herculean Ferrara: Ercole d'Este, 1471-1505, and the Invention of a Ducal Capital (Cambridge: Cambridge University Press, 1996), 220-1. 
21 Tuohy, Herculean Ferrara, 222.

22 Thornton, Italian Renaissance Interior, 207. Tuohy, Herculean Ferrara, 229.

23 Translated and quoted in Syson and Thornton, Objects of Virtue, 160.

24 Quoted in Eva Helfenstein, 'Lorenzo de' Medici's Magnificent Cups: Precious Vessels as Status Symbols in Fifteenth-Century Europe', I Tatti Studies, 16 (1/2) (2013), 440-1. Also see F. W. Kent, Lorenzo de' Medici and the Art of Magnificence (Baltimore, MD and London: Johns Hopkins University Press, 2004), 32.

25 Paula Hohti, 'Domestic Space and Identity: Artisans, Shopkeepers and Traders in SixteenthCentury Siena', Urban History, 37 (3) (2010), 383, note 40; Roy C. Strong, Feast: A History of Grand Eating (London: Jonathan Cape, 2002), 129-35.

26 Taylor, 'Banquet Plate', 631.

27 Welch, Shopping, 90-3; Ann Matchette, 'Credit and Credibility: Used Goods and Social Relations in Sixteenth-Century Florence,' in The Material Renaissance, eds Michelle O’Malley and Evelyn S. Welch (Manchester and New York: Manchester University Press, 2007), 225-41.

28 Adrian Randolph, 'Performing the Bridal Body in Fifteenth-Century Florence', Art History, 21 (2) (1998), 182-200; Timothy McCall, 'Brilliant Bodies: Material Culture and the Adornment of Men in North Italy's Quattrocento Courts', I Tatti Studies: Essays in the Renaissance, 16 (2013), 445-90; Leah R. Clark, 'Transient Possessions: Circulation, Replication, and Transmission of Gems and Jewels in Quattrocento Italy', Journal of Early Modern History, 15 (3) (2011), 184-221.

29 Evelyn S. Welch, 'Women in Debt: Financing Female Authority in Renaissance Italy', in Donne di potere nel Rinascimento, eds Letizia Arcangeli and Susanna Peyronel (Rome: Viella, 2008), 53.

30 ASMO Ambasciatori Milano (AMB MIL) 3. 241-2. The letter is dated 22 September 1479.

31 The practice of naming jewels was already evident in the medieval period and not just in Europe but also in the Islamic context: see Avinoam Shalem, 'Jewels and Journeys: The Case of the Medieval Gemstone Called al-Yatima', Muqarnas, 14 (1997), 42-56.

32 'Paola Venturelli, Glossario e documenti per la gioielleria Milanese (1459-1631) (Florence and Milan: La Nuova Italia 1999): 157, doc 26. Also see McCall, 'Brilliant Bodies', 459.

33 Paola Venturelli, Esmaillée à la façon de Milan: smalti nel Ducato di Milano da Bernabò Visconti a Ludovico il Moro (Venice: Marsilio, 2008), 96.

34 Filena Patroni Griffi, Banchieri e gioielli alla corte aragonese di Napoli (Naples: Francesco Giannini \& Figli, 1984), 20-1. From Archivio di Stato di Firenze, cart. strozziane 47, 99. For the Strozzi bank see Alfonso Leone (ed.) Il giornale del Banco Strozzi di Napoli (1473), Fonti e documenti per la storia del Mezzogiorno d'Italia (Naples: Guida Editori, 1981).

35 Michele Jacoviello, 'Affari di Medici e Strozzi nel regno di Napoli nella seconda metà del Quattrocento', Archivio storico italiano, 144 (1986), 180.

36 David Abulafia, 'The Crown and the Economy under Ferrante I of Naples (1458-94)', in City and Countryside in Late Medieval and Renaissance Italy. Essays Presented to Philip Jones, eds Trevor Dean and Chris Wickham (London and Ronceverte: Hambledon Press, 1990), 136.

37 Griffi, Banchieri, 20.

38 Richard Brown, 'Death of a Renaissance Record-Keeper: The Murder of Tomasso da Tortona in Ferrara, 1385', Archivaria, 44 (1997), 37, note 30.

39 McCall, 'Brilliant Bodies', 457.

40 Salomon, 'Barbo's Collection', 10.

41 David S. Chambers, 'The Economic Predicament of Renaissance Cardinals', in Renaissance Cardinals and Their Worldly Problems, ed. David Sanderson (Aldershot: Variorum, 1997), 289-313.

42 Quoted in Rembrandt Duits, 'Figured Riches: The Value of Gold Brocades in FifteenthCentury Florentine Painting', Journal of the Warburg and Courtauld Institutes, 62 (1999), 72.

43 William P. Caferro, 'Warfare and Economy in Renaissance Italy, 1350-1450', Journal of Interdisciplinary History, 39 (2) (2008), 191.

44 Welch, Shopping, 197-8.

45 Clifford M. Brown, 'Cardinal Francesco Gonzaga's Collection of Antique Intaglios and Cameos: Questions of Provenance and Dispersal Identification', Gazette des Beaux Arts, 125 (1983), 101-3. 


\section{2}

\section{Dispersal, Exchange and the Culture of Things}

46 Jacqueline Marie Musacchio, 'The Medici Sale of 1495 and the Second-Hand Market for Domestic Goods in Late Fifteenth-Century Florence', in The Art Market In Italy. 15th-17th Centuries/Il mercato dell'arte in Italia secc. XV-XVII, eds Marcello Fantoni, Louisa C. Matthew and Sara F. Matthews-Grieco (Ferrara: Franco Cosimo Panini Editore, 2003), 313-23. Venturelli, Esmaillée a Milan, 96.

47 Welch, Shopping, 195.

48 Musacchio, 'Medici Sale of 1495', 314-15.

49 Salomon, 'Barbo's Collection', 11; Roberto Weiss, The Renaissance Discovery of Classical Antiquity (Oxford: Basil Blackwell, 1973), 187.

50 Helfenstein, 'Lorenzo's Magnificent Cups', 443; Ulrico Pannuti, 'Formazione, incremento e vicende dell'antica raccolta glittica medicea', in Il tesoro di Lorenzo il Magnifico. Le gemme. Catalogo della Mostra Palazzo Medici Riccardi, eds Nicole Dacos, Antonio Giuliano and Ulrico Pannuti (Florence: Sansoni Editore, 1973), 14, note 24.

51 Quoted and translated in Creighton E. Gilbert, 'Ghiberti on the Destruction of Art', I Tatti Studies in the Italian Renaissance, 6 (1995), 142.

52 Webb Keane, 'Signs Are Not the Garb of Meaning: On the Social Analysis of Material Things', in Materiality, ed. Daniel Miller (Durham, NC and London: Duke University Press, 2005), 188. 


\title{
7 Michelangelo, Tommaso de' Cavalieri and the Agency of the Gift-Drawing
}

\author{
Alexander Lee
}

\section{Introduction}

Shortly after taking up residence in Rome in late August or early September 1532, the 57-year-old Michelangelo met Tommaso de' Cavalieri for the first time. ${ }^{1}$ It is possible that they may have been introduced by a mutual friend, Pier Antonio Cecchini; ${ }^{2}$ but however they made each other's acquaintance, their path to intimacy was smoothed by the younger man's artistic temperament. The Cavalieri were noted collectors, ${ }^{3}$ and despite his youth (he was not yet twenty), Tommaso was a sensitive connoisseur with aspirations of his own. ${ }^{4}$ Before long, they were inseparable, and a bond was forged that would last until Michelangelo's death more than thirty years later.

The earliest documentary evidence of their burgeoning relationship is provided by three letters written between December 1532 and January 1533. The first is an undated draft written in a state of anxiety. Sometime earlier, Michelangelo had sent Tommaso a (now lost) message, together with a gift of two drawings, but having heard nothing since, he had begun to repent of his rashness and hastily scribbled the note asking to be forgiven for having written inconsideratamente. ${ }^{5}$ Before he could dispatch it, however, he received a letter of thanks from Tommaso brimming over with affection, ${ }^{6}$ and to which he then replied - with a palpable sense of relief - on 1 January $1533 .^{7}$

The two 'gift-drawings' that elicited this exchange were the Rape of Ganymede (Cambridge, MA, Fogg Art Museum) - the original of which has been lost - and the Punishment of Tityus (Windsor, Royal Library). ${ }^{8}$ In both technical and narrative terms, they were ambitious works. Unlike many of Michelangelo's earlier drawings - such as the Three Heads, the Fury and the Zenobia (Florence, Uffizi) sent to Gherardo Perini in the previous decade ${ }^{9}$ - they employed a 'rich diversity of graphic techniques' to articulate complex mythological scenes, while displaying a striking unity of conception. ${ }^{10}$

According to the 1568 version of Vasari's Vite, the Ganymede and the Tityus may have been intended to teach Tommaso how to draw. ${ }^{11}$ As Maria Ruvoldt has recently pointed out, this claim should not be dismissed too lightly. ${ }^{12}$ Michelangelo was fond of using drawings as teaching aids, ${ }^{13}$ and it is possible that Cavalieri may have recognised them as such, promising in his letter of thanks to study them each day. ${ }^{14} \mathrm{It}$ was, indeed, not long before they were being admired as models of the graphic arts and copied accordingly, albeit not by Tommaso. In acknowledging receipt of a later gift, Cavalieri wrote that everyone, including Pope Clement VII and Cardinal Ippolito de' Medici, had clamoured to see the drawings. ${ }^{15}$ Ippolito was so enamoured, in fact, 


\section{4}

The Agency of the Gift-Drawing

that he took the Tityus with him in order to have it reproduced in rock crystal, and it had only been with the greatest difficulty that he had been prevented from taking the Ganymede as well. ${ }^{16}$

But they were evidently more than mere models for imitation. While Michelangelo may have known that they would be circulated among Cavalieri's Roman coterie, they were nevertheless imbued with a deeply personal meaning, meant for Tommaso alone, a fact upon which Pietro Aretino was later to remark. ${ }^{17}$ Linked thematically as well as visually, they expressed the artist's growing affection for the young nobleman in terms familiar to Florentine Neoplatonism. ${ }^{18}$ In the first, Ganymede, a Trojan shepherd of incomparable beauty, swoons with delight as he is carried aloft by the impassioned Zeus - in the form of an eagle - to become the cupbearer of the gods. ${ }^{19}$ Perhaps informed by Cristoforo Landino's commentary on Dante, Purg. 9.22-4, the scene symbolised the amor sacro that had been kindled in Michelangelo's heart. ${ }^{20}$ Powerless to resist the pure, spiritual love by which he had been seized, his soul was raised above the base concerns of the material world and carried in ecstasy towards the divine. ${ }^{21}$ The second is more subtle. Here, the giant Tityus lies bound to the Tartarean rocks, twisting in anticipated agony as a gigantic eagle bends to peck out his eternally recrudescent liver, a fitting punishment for his attempted rape of Zeus' beloved Latona. For Michelangelo - as for Dante, Boccaccio, Landino and Battista Mantovano - the tale stood as an allegorical indictment of amor profano. ${ }^{22}$ Should free rein be given to sexual desire, it warned, the soul - like the giant - would be brought low and condemned to suffer eternally. As such, it served to reinforce the sense of purity and propriety with which Michelangelo sought to clothe his feelings. But it could also represent the 'sweet sorrow' that all lovers endure for their unrequited affections. ${ }^{23}$ Thus developing an allegorical reading found in the poetry of Girolamo Bologni, Jacopo Sannazaro and Antonio Tebaldeo, it could be read as a statement of the pain Michelangelo would suffer if his love were not returned. ${ }^{24}$

As such, the two scenes were both confessional and constitutive. Flattering Tommaso's intellectual vanity with their use of classical mythology, they invited the young nobleman to recognise and reciprocate the spiritual love they articulated; and though the contents of Michelangelo's heart were visible only through a glass darkly, they strove to establish a bond in which his amor sacro could be declared more plainly.

The intimacy that the Ganymede and the Tityus were intended to establish was nurtured by their status as drawings. Far removed from the constraints of contractual relations, they inhabited a realm of free expression and personal experience open only to the individual for whom they had been composed. Small in size and unhindered by iconographical norms, they could be approached only through close study and solitary meditation, viewing practices which - by their very nature - generated an inescapable sense of privacy and secrecy. ${ }^{25}$

This paper will seek to explore the manner in which this same intimacy was also shaped and negotiated by their status as gifts. Although Vasari portrayed them as presents much like any others that Michelangelo gave to his friends, an examination of his letters alongside conventional forms of gift exchange and Reformist notions of the beneficium suggests that he intended them to perform a far more active role in constituting the bond he sought with Cavalieri. Granted an agency of their own, they allowed Tommaso to be co-opted into the very drama they allegorised, and - free from expectation and obligation - paved the way for the two men to refine the relationship into which they had been drawn as they saw fit. 


\section{Michelangelo and the Culture of Gift-Exchange}

The giving of gifts was not unusual in sixteenth-century Italy. As in most other cultures throughout history, it was the oil that greased the wheels of social life. Through the exchange of carefully chosen items, new bonds were forged, existing ties consolidated and old alliances renewed. ${ }^{26}$ The contexts in which it could be practised were almost limitless, as were the purposes to which it could be put. It was a custom without which no respectable marriage was complete, and which accompanied such rites of passage as childbirth, baptism and even death. ${ }^{27}$ In much the same way, magistrates raided civic treasuries to offer lavish gifts to ambassadors; ${ }^{28}$ merchants gave notaries presents of anchovies, wine and firewood; ${ }^{29}$ and love-struck young men sent sweetmeats, rings and other highly decorated items to the women they admired. ${ }^{30}$

It was the expectation of reciprocity that gave gifts their potency. They were, after all, given so that they might be received, or - in some cases - so that a favour might be repaid, and it was by imposing or fulfilling an obligation that they fomented relationships. Yet how this obligation was understood depended on the relative status of donor and recipient. In some contexts, such as marriage, gender was the dominant consideration; in others, it was often age; but in most cases, it was through the prism of wealth or social class that the practice was refracted.

Michelangelo was highly attuned to the ritualism of gift-giving. He was the recipient of a great many presents throughout his life, ${ }^{31}$ and despite his reputation for miserliness, was generous in bestowing gifts on others. ${ }^{32} \mathrm{He}$ knew all too well the obligations that giving or receiving entailed, and was sensitive to the strict sense of social standing that governed the rituals of exchange. As Vasari reported, he was sometimes even reluctant to accept presents, because he feared that in doing so he would be forever beholden to those from whom they were received, ${ }^{33}$ and in later years, he found himself subjected to a stinging rebuke from Aretino for not reciprocating the poet's pushy 'gift' of praise with a drawing such as he had sent to Cavalieri. ${ }^{34}$

As the self-accusatory tone of his letters suggests, Michelangelo was conscious of having taken a risk in sending the Tityus and the Ganymede. In ordinary circumstances, it would have been Tommaso who - by virtue of his nobility - would have been expected to have initiated a correspondence. On receipt of a letter, Michelangelo would have been in a position not only to reply, but also to send a gift in return. In the anthropological terms of Mauss and Leenhardt, such a gift could be characterised as a 'prestation', that is, a form of reciprocation offered out of obligation, repaying Cavalieri for the magnanimitas of his initial letter. ${ }^{35}$ As such, Tommaso could then have accepted the gift-drawings with perfect propriety, and viewed the exchange as a consolidation of a hierarchical relationship in which he was the superior.

In sending his gift-drawings as he did, however, Michelangelo trespassed into another, more problematic, ritual environment. By giving the two pieces not out of obligation, but as what Parry has called a 'pure gift', the artist was placing Cavalieri under an obligation to reciprocate. ${ }^{36}$ It would, in other words, seem as if he were offering the gift-drawings in anticipation of receiving some beneficence in return; that is, as if he were asking for something from Tommaso.

This was, of course, not unknown in the realm of artistic gift-giving. Just as humanists frequently dedicated their works to prospective patrons, so it was common for artists to give their works to prominent figures in the hope of receiving further patronage. According to Vasari, Rosso Fiorentino presented King Francis I of France with 
a series of paintings with precisely this intention in $1530 .{ }^{37}$ So delighted was the king that he granted him an allowance of 400 crowns and a house in Paris. Likewise, Vasari reports that in 1524, Parmigianino gave four pictures - including the Self-Portrait in a Convex Mirror (Vienna, Kunsthistorisches Museum) - to Pope Clement VII, from whom he subsequently received a host of favours. ${ }^{38}$ In the following century, Malvasia even related that Guido Reni actually preferred giving his paintings as gifts to princes who would lavish gifts on him rather than sell them. ${ }^{39}$

Nor, indeed, was Michelangelo a stranger to the practice. From his earliest days, he had habitually offered his works to influential figures in the hope of securing their patronage. The Strozzi were frequent recipients of such gifts. It has been suggested that he may have given the family a statue of Hercules as early as $1494,{ }^{40}$ and it is beyond doubt that he asked his brother, Buonarroto, to give a dagger originally commissioned by Piero Aldobrandini to Filippo Strozzi with the same end in mind in $1507 .{ }^{41}$

In the case of the Ganymede and the Tityus, of course, nothing could have been further from Michelangelo's mind. His object was patently neither patronage nor profit. Yet in sending the drawings so 'inconsiderately' - as unsolicited gifts - he risked Tommaso construing them in precisely this light.

\section{Gifts and Grace}

The obvious solution was to transplant his gifts into a different setting. This was not as implausible a prospect as it might have seemed. Despite the ubiquity of the gift economy, there was a long tradition of thought that viewed gratuitousness, rather than reciprocity, as the distinctive characteristic of gift-giving, and that hence envisaged a different ritual context for the gift itself. The outlines of the argument had first been set out in Seneca's De beneficiis. 'The logic of gifts is simple,' he wrote; 'so much is given; if something is returned, it is gain; if not, there is no loss. I gave it for the sake of giving. ${ }^{42}$ Rather than imposing an obligation on the recipient, bestowing a gift (beneficium) was simply a good. As the Church Fathers recognised, this was an idea that chimed with Christian notions of caritas. ${ }^{43}$ Though critical of Seneca's paganism, ${ }^{44}$ Augustine used it to describe the divine gift of Christ's incarnation and sacrifice, which could never be reciprocated. ${ }^{45}$ Thus granted a place in the economy of grace, it gained wider currency in later centuries, and was taken up with particular enthusiasm by the Protestant Reformers. ${ }^{46}$ John Calvin - an avid reader of both Seneca and Augustine posited that grace was a gift which God granted out of love, without regard to merit, and which hence contained no expectation of return. ${ }^{47}$ In like fashion, the Beneficio di Cristo emphasised that grace, by its very nature, was impossible to reciprocate. ${ }^{48}$

Such ideas were current amongst the Viterbo circle, many of whom were sympathetic to reformist tendencies. Using Erasmus' recent edition of the text, Benedetto Varchi produced a translation of the De beneficiis that - if anything - stressed the gratuitous nature of the gift even more than Seneca had done. ${ }^{49}$ And as Alexander Nagel has demonstrated, Michelangelo was sufficiently well-attuned to this understanding of gift-giving to appropriate it to his own purposes some years later. ${ }^{50}$ Having received a gift from Vittoria Colonna, probably of poems, he claimed that he was at first inclined to reciprocate, in order not to remain unworthily in her debt. ${ }^{51}$ But on reflection, he realised that her gift - like divine grace - had been offered out of caritas. It would hence have been both unnecessary and impossible to recompense her, whose kindness was so heavenly. But his acceptance nevertheless allowed a different form of relationship to be forged. 
It was an elegant conceit and could readily be turned into a delicate compliment. Yet it would have been inconceivable for Michelangelo to have attempted anything similar in his letters to Cavalieri. Here, he was the donor, rather than the recipient. It would have been crude in the extreme for him to have depicted himself as he was later to do in his letters to Vittoria Colonna, and since a gratuitous gift necessarily had no regard for the merits of the person to whom it was given, Michelangelo would surely have offended Tommaso's dignity in portraying his drawings as such gifts. If the young Roman were to recognise them as the bounty of spiritual love, rather than as mercenary offerings, Michelangelo evidently had to ensure that they were received in a different manner.

\section{The Agency of the Gift-Drawing}

To achieve this, he relied on the agency of the gift-drawings themselves. At the heart of his strategy was a re-evaluation of the interaction between beneficium and verbum. Where gifts were given in the context of an unequal social relationship, they were commonly accompanied by a text in which the offerings were described. Although often laced with exaggerated statements of modesty, such texts were intended to condition the manner in which the recipient understood the character of the relationship that was desired and the form of reciprocity that was expected. ${ }^{52}$ Michelangelo, however, had no wish to exercise such control. Apparently speaking of another gift in the postscript to his letter of 1 January 1533, he acknowledged that it would have been right for him to say what gifts he was sending, but nevertheless preferred to remain silent, thus abdicating any influence over their reception. ${ }^{53}$ In doing so, he freed Tommaso from preconceptions about how his gifts were to be viewed, and focused attention on the drawings, thus endowing them with an agency of their own. Instead of serving merely as a cipher, they were allowed to speak for themselves, and the implicit dialogue that would otherwise have taken place between Michelangelo and Tommaso was sublimated into a dialogue between Tommaso and the drawings.

This conscious act of surrender prevented any mercenary designs from being attributed to Michelangelo. What was more, any bond forged between the two men would be decided by Tommaso and the gift-drawings. But Michelangelo's renunciation also placed an unusually high demand on Cavalieri as the viewer. In order to decide how they should be understood as gifts, he was obliged to make a special interpretative effort. Only by examining these small and intimate works in the privacy of solitary contemplation would he determine what function they were meant to perform and what sort of relationship they were designed to foment. ${ }^{54}$

Yet this only exposed Michelangelo to a further danger. As Vasari remarked, he had a talent for ambiguity. In conversation, his 'veiled and ambiguous manner of speech' often gave his utterances 'in a sense, two meanings', with the result that his listeners could misinterpret what he was trying to say. ${ }^{55}$ This would have been problematic enough when he was there in person to address any misunderstandings that might have arisen, but the effects could be even more pronounced when he chose to apply this 'veiled' manner to his art, especially when he was determined to give his work a life of its own. As we have already seen, the Ganymede and the Tityus were complex works, and in the absence of an accompanying letter, they were all the more difficult to decipher. There was simply no means of predicting what agency they might exercise. ${ }^{56}$ Indeed, there was every chance that they could provoke responses quite 


\section{8}

\section{The Agency of the Gift-Drawing}

different from those that Michelangelo was hoping for, and undermine - or even destroy - the intimacy he wished to establish.

Such fears would not have been entirely unjustified. While their friendship was already sufficiently advanced for Michelangelo to address Cavalieri as luce del secol nostro, unica nel mondo in late December, they were not so intimate that he could anticipate the young man's reactions with any certainty. As the self-recriminatory tone of his first, unsent letter suggests, he could not shake the suspicion that he might have mistaken youthful enthusiasm and aristocratic courtesy for a genuine warmth of feeling. Even months later, the same fear continued to plague him whenever he was away from Rome. Although he affected a confident tone in his letters to Tommaso, he expressed great anxiety in correspondence with his friends. ${ }^{57} \mathrm{He}$ pestered Sebastiano del Piombo for news, ${ }^{58}$ and was so worried that Bartolomeo Angelini had to reassure him of Tommaso's affection almost every week. ${ }^{59}$

More worrying still was the possibility that Cavalieri might misconstrue his love altogether. It was not enough simply to profess the purity of his sentiments. In the popular imagination, the boundary between spiritual and physical passion between men was apt to appear porous. ${ }^{60}$ Amor sacro and amor profano were, after all, both forms of amor, and in a world of linguistic ambiguities, it was fruitless to try splitting hairs. It was not long before malicious rumours about Michelangelo's attachment to Tommaso began to spread. In a sonnet written in $c .1534$, he chaffed against the 'malevolent, cruel, and foolish rabble' that accused him of nurturing the same base desires as them. ${ }^{61}$ In a separate verse, he even doubted whether the casta voglia that burned within his heart would ever be understood 'by those who always see themselves in others' ${ }^{62}$ Naturally, he was deeply pained that he was barred from seeing Tommaso when the young man chose to listen to such lies. ${ }^{63}$ But the legal penalties that could have befallen him as a result of these rumours would have been more troubling still. Despite the incidence of sexual relationships between men in his native Florence, the punishments that were meted out to those convicted of sodomy were often harsh, ${ }^{64}$ and artists were certainly not immune. During Michelangelo's own lifetime, accusations were levelled against Leonardo da Vinci, Sandro Botticelli and Benvenuto Cellini, and it was only by good fortune that they had been spared harsh chastisements. ${ }^{65}$ As a later poem addressed to Luigi del Riccio appears to suggest, he was only too well aware of the sword of Damocles hanging above him, ${ }^{66}$ and it is likely to have been this that prevented him simply affirming his love for Tommaso in the letters accompanying his gifts. It was, after all, precisely because of the threat by which he was confronted that Ascanio Condivi and Giorgio Vasari went to such great pains to absolve him of harbouring any 'improper' desires after his death. ${ }^{67}$

Yet despite the risk he was taking, Michelangelo was still unwilling to compromise the agency of his drawings. Instead, he attempted to counterbalance his own lack of control by quietly transforming the role of the recipient. Although we lack the letter that originally accompanied the Ganymede, the nature of this change can be gleaned from the draft he wrote in December 1532. Aware that his words - like the drawings themselves - could be misinterpreted, he urged Cavalieri to look beneath the surface of the missive. 'Read the heart and not the letter,' he implored, for - as Petrarch had put it in his first canzone - 'my pen cannot follow closely my good will.' ${ }^{68}$ The quotation had not been chosen idly. ${ }^{69}$ In the original verse, Petrarch had described the transformative effects of his first encounter with Laura, and had portrayed himself being pursued by love as cruelly as Actaeon had been pursued by his dogs. So deeply had he been stung 
by Laura's coldness that he could not hope to tell all that was in his mind, and hence resolved only to record that which was most remarkable about his loss of selfhood con carta e con incostro (11.98-100). In this way, he hoped to make himself worthy of Laura's mercy, even though he was aware that such self-abasement could provoke either love or disdain (11.101-6). But he nevertheless hoped that his beloved would see his humility for what it was and, forsaking her usual custom, reflect God's grace in looking on him kindly (1l.121-31). Such was Michelangelo's hope also, and had he sent his draft, he would surely have expected that his quotation - once identified - would have encouraged Tommaso to show 'divine' qualities in seeking out the true spirit of his drawings. Though couched in the most delicate terms, this had important implications. Rather than gift-giving being an expression of caritas, it was hence gift-receiving that was revealed to be an act of grace. The donor, having already renounced control over the agency of the gift, became an unworthy postulant, and, in turn, the almost divine recipient conferred a blessing merely in declining to disdain the gift that was proffered.

Michelangelo's conceit paid off. Even though his draft remained unsent and unseen, Cavalieri signalled his acquiescence in the scheme, at least as far as he was able. Thanking Michelangelo for having shown him 'no little affection', he recognised the gift-drawings as expressions of amor sacro, and, while still revelling in a sense of his own superiority, had the good taste to raise the artist from the lowly station he had assigned himself. Responding directly to the Neoplatonic and Petrarchan implications of the two images, he acknowledged that they had been given merely out of a love of the good. 'I think, in fact, I am certain,' he wrote, 'that the affection you bear me is because of this - that you, being extremely virtuous, or rather virtue itself, are compelled to love those who follow and love virtue, among whom I, according to my abilities, yield to few.' 70

Having thus located the gift-drawings in the context of a spiritual love akin to worship, Tommaso accepted them without feeling any obligation to reciprocate in material terms. Yet his acceptance was a form of reciprocity in itself. In his letter of thanks, he not only sanctioned Michelangelo's love, but also responded in kind. 'I have never borne more love for a man than for you, nor have I ever desired anyone's friendship more than yours,' he gushed, before promising to visit the artist in person very soon, if fortune allowed, and resolving to study the drawings for at least two hours each day in the meantime. ${ }^{71}$ This was just what Michelangelo wanted. Yet, sustaining the Petrarchan spirit of his earlier draft, he viewed this almost as an act of supplementary grace. Had his gifts been spurned, he would have thought himself in disgrace with heaven and earth', but that Tommaso had willingly accepted his drawings - and hence shown him a comparable love - caused him 'great wonder and no less pleasure', almost, in fact, as if he had received a gift from heaven itself. ${ }^{72}$

\section{Re-imagining the Gift}

The agency that had allowed Michelangelo's gift-drawings to function outside the bounds of gratuitous giving and reciprocal exchange was, however, short-lived. No sooner had they been accepted than Cavalieri translated them back into the familiar language of the gift economy, and so effected a transformation in the character of the relationship they had helped create.

Though his pride had been flattered, Tommaso was aware of their difference in age, and coyly used this to invert the roles that Michelangelo's gifts had assigned 


\section{0}

\section{The Agency of the Gift-Drawing}

them. In his letter of thanks, he wondered that so excellent a man as Michelangelo should have wished to write to 'a young man only just born in the world'. ${ }^{73}$ Even though they might occupy different stations in life, it seemed obvious that he could not match the artist's learning, talent, or experience, and could not hope to add lustre to Michelangelo's qualities through their correspondence. As such, he implied that the gift-drawings should best be understood as acts of loving magnanimitas bestowed on one inferior in years by another of greater wisdom. This was, of course, not a situation that was entirely unknown, even in the Viterbo circle. In 1527, Benedetto Varchi fell in love with the ten-year-old Lorenzo Lenzi, and in the exchange of poems that soon followed, it was their difference in age that was habitually used to cloak the giving and receiving of such literary gifts. ${ }^{74}$ But that Tommaso should have chosen to re-imagine both gift-drawings and relationship in such a way was nevertheless a touching gesture that Michelangelo would certainly have appreciated.

This was, however, merely the first stage in a rapidly evolving negotiation. In reply, Michelangelo countered Tommaso's suggestion that he had just been born by claiming that he had, in fact, 'been in this world a thousand times before'. ${ }^{75}$ This was not merely a courtly compliment, but also an allusion that developed the Petrarchan borrowings that Michelangelo had earlier annexed to his understanding of the gift. Both before and after Laura's death, Petrarch had claimed that he had been trapped by thousands of Love's snares, ${ }^{76}$ and had sufficient ardour to inflame thousands of verses. ${ }^{77} \mathrm{He}$ had, moreover, endured mille morti without her ever shedding so much as a tear, ${ }^{78}$ and had suffered sweet sorrow mille volte, begging God always for the wings that would carry his intellect from this mortale carcer heavenwards. ${ }^{79}$ One particularly affecting sonnet even begins with the lines:

a thousand times, o my sweet warrior,

in order to have peace with your lovely eyes,

I have offered you my heart. ${ }^{80}$

Picking up precisely such passages, Michelangelo contrived to place himself in Petrarch's 'masculine' role, and cast Tomasso in Laura's 'feminine' - or at least 'feminised' - position. In doing so, he effected a shift in the nature of his gifts. Having formerly been offered in unworthy, but hopeful, adoration, they were now reconceived as a form of supplication that would not have been out of place in the courtship rituals of the gift economy. In these, a male lover conventionally offered gifts to his female beloved that articulated his passion in a manner not dissimilar to Michelangelo's drawings. Often making use of mythological themes, or echoing Petrarchan verses, these manifested both the purity of the lover's passion and the sweet suffering he endured. On a maiolica dish from Deruta now in the Victoria \& Albert Museum and probably datable to $c .1470-90$, a woman is shown bearing a dish on which has been placed a heart pierced by two arrows. If further explanation were needed, the inscription reads el mio core é ferito $p$ [er] voe ('my heart is wounded by you'). On another two-handled cup from Deruta, a winged cupid holds a dish containing a heart similarly pierced by an arrow, accompanied by the inscriptions quista te dono $p[e r]$ amore bella ('I give you this, beautiful one, as a token of my love') and $p$ [er] amore te porto in quissa copa bella ('for the love I bear thee in this fine cup'). This, in turn, transformed the nature of acceptance once again. Rather than being seen as an act of grace, Tommaso's willingness to receive Michelangelo's gift could 
now be seen not only as a symbolic recognition and reciprocation of affection, but also as an invitation to proceed to a further exchange of gifts that would - in other contexts - have led to betrothal and marriage.

It was a far cry from the bond first forged through the agency of Michelangelo's gift-drawings. But such retrospective transformations both of gift-giving and of the relationships they fostered were not uncommon, especially within the Viterbo circle. It was, indeed, a ritual in itself. Only a few years later, Vittoria Colonna's gift of a bound manuscript of her sonnets was accepted by Marguerite de Navarre, and the bond between them was almost immediately subjected to a sequence of re-evaluations that recall the steps followed by Michelangelo and Tommaso. ${ }^{81}$ Despite having abased herself before the queen, Colonna received a letter of thanks in which their roles were dramatically reversed. Professing her own moral inferiority, Marguerite expressed her desire to learn from Colonna (whom she cast as her guide), and thereby attain to a higher plane of spiritual understanding. ${ }^{82}$ In response, Colonna reaffirmed her humility, but nevertheless opened the doors to a mutually beneficial relationship. ${ }^{83}$

There was, however, an important difference. In the correspondence between the two women, it had been Colonna's opening letter that had played the decisive role. Her self-effacing words had specified how her gift was to be received, and made it clear that Marguerite was at liberty to re-imagine their relationship as soon as it had been accepted. Yet Michelangelo - who, by virtue of offering such potent gifts to another man, laboured under more constraints - achieved the same effect in silence. By according his gift-drawings such agency, he had allowed Tommaso not only to construe them more freely and sympathetically than would otherwise have been possible, but also to re-construe the relationship they fomented as he saw fit. As such, he ensured that they would facilitate ever greater intimacy, and pave the way for the dissolution of those societal norms that had necessitated his reliance on the agency of the gift-drawings in the first place.

\section{Conclusion}

As I have attempted to demonstrate in this paper, the characteristics usually held to be most distinctive of Michelangelo's two drawings were complemented, reinforced and even facilitated by their status as gifts. In much the same way as the two pieces were conceived as autonomous artworks outside the normal economy of artistic production, so they were also designed to function as gifts with an independent agency of their own, outside the normal economy of gift exchange. In keeping with the different viewing practices imposed by their restricted scale, this imposed challenging interpretative demands on Tommaso as the recipient. Examining them without the textual assistance that commonly accompanied gifts, Cavalieri was induced to accept them neither as a patron encumbered by the weight of reciprocal obligations, nor as the unworthy recipient of caritas, but as a quasi-divine bearer of grace responding to the adoration of one consumed by Neoplatonic amor sacro. As such, acceptance itself became both an act of implied reciprocation and - more importantly - an act of shared spiritual love. Yet in the same moment, the gift-drawings also sacrificed their agency to allow for a broader and freer renegotiation of the terms of the bond they had forged. Elevating both recipient and donor to a plane of unusual liberty, they allowed that relationship to be overlaid with a sense of generational difference, and in that they subsequently came to parallel the function of conventional love-tokens, they also served to 


\section{The Agency of the Gift-Drawing}

establish new gendered identities for the two men that echoed the roles implicit in the very themes of the Tityus and the Ganymede.

This raises further questions about the character of the gift-drawing in general. Given that Michelangelo composed a number of other drawings for Tommaso, including the notoriously problematic Childrens' Bacchanal (Windsor, Royal Library), we might reasonably ask what the notion of the gift might add to our understanding of these works. Since such questions have already been asked of drawings produced for other recipients - most notably the Pietà (Boston, Isabella Stewart Gardner Museum) given to Vittoria Colonna - we may also begin to inquire into the consistency and evolution of Michelangelo's understanding of the gift-drawing over time. At a more fundamental level, an appreciation of the importance of the status of the gift to the Tityus and the Ganymede invites an examination of the broader role played by giftgiving in shaping the development of the drawing as an autonomous art-form. Such questions, are, however, beyond the modest scope of this paper. But though leaving them unanswered may afford only the sweet sorrow known to Michelangelo's Tityus, it is hoped that future studies may rise from their rocky crags to the same heights of intellectual delight as his Ganymede enjoyed.

\section{Notes}

1 On Michelangelo's arrival in Rome, see Michael Hirst, Michelangelo: The Achievement of Fame, 1475-1534 (New Haven, CT and London: Yale University Press, 2011), 260.

2 Christoph Luitpold Frommel, Michelangelo und Tommaso dei Cavalieri (Amsterdam: Castrum Peregrini Presse, 1979), 14-15; William E. Wallace, Michelangelo: The Artist, the Man, and His Times (Cambridge: Cambridge University Press, 2010), 77; Hirst, Michelangelo, 261. On Cecchini as a go-between in later years, see, for example, Il Carteggio di Michelangelo, eds Paola Barocchi and Renzo Ristori, 5 vols (Florence: Sansoni, 1965-83), 3: 443-4, 4: 3 .

3 Frommel, Michelangelo und Tommaso dei Cavalieri, 69-70; Ernst Steinmann and Heinrich Pogatscher, 'Dokumente und Forschungen zur Michelangelo, IV, Cavalieri-Dokumente', Repertorium für Kunstwissenschaft, 29 (1906), 496-517, here 502-4. On the Cavalieri family more generally, see, for example, Stephanie Buck (ed.), Michelangelo's Dream (London: Paul Holberton, 2010), 76-7; Warren Kirkendale, Emilio de' Cavalieri, 'Gentiluomo Romano' (Florence: L. S. Olschki, 2001), 13-27.

4 Giorgio Vasari, Le vite de' piu eccellenti pittori, scultori ed architettori, ed. G. Milanesi, 9 vols (Florence, 1878-85), 7: 271. On the date of Tommaso's birth, see Frommel, Michelangelo und Tommaso dei Cavalieri, 72.

5 Carteggio, 3: 443-4.

6 Carteggio, 3: 445-6.

7 Carteggio, 4: 1-2.

8 On the term 'gift-drawing' see William Wallace, 'Studies in Michelangelo's Finished Drawings, 1520-1534' (unpublished PhD dissertation, Columbia University, 1983). On the original of the Ganymede, see Michael Hirst, 'A Drawing of the Rape of Ganymede by Michelangelo', Burlington Magazine, 107 (1975), 166.

9 On which see, for example, Hirst, Michelangelo and His Drawings, 107-9; Michelangelo, 202.

10 Hirst, Michelangelo and His Drawings, 112. On Michelangelo's renewed interest in classical mythology, see Maria Ruvoldt, 'Michelangelo's Mythologies', in Renaissance? Perceptions of Continuity and Discontinuity in Europe, c.1300-c.1550, eds Alexander Lee, Pit Péporté and Harry Schnitker (Leiden: Brill, 2010), 207-24.

11 Vasari, Le vite, ed. Milanesi, 7: 271.

12 Maria Ruvoldt, 'Michelangelo's Open Secrets', in Visual Cultures of Secrecy in Early Modern Europe, eds Timothy McCall, Sean Roberts and Giancarlo Fiorenza (Kirksville, MO: Truman State University Press, 2013), 105-25, here 116-17. 
13 See Charles de Tolnay, Corpus dei disegni di Michelangelo, 4 vols (Novara: Istituto geografico De Agostino, 1975-80), nos. 317-19; Wallace, 'Studies in Michelangelo's Finished Drawings', 43-82; Michael Hirst, Michelangelo and His Drawings (New Haven, CT and London: Yale University Press, 1988), 13-14; William E. Wallace, 'Instruction and Originality in Michelangelo's Drawings', in The Craft of Art: Originality and Industry in the Italian Renaissance and Baroque Workshop, eds Andrew Ladis and Carolyn H. Wood (Athens, GA: University of Georgia Press, 1995), 113-33.

14 Carteggio, 3: 445-6.

15 Carteggio 4: 49.

16 Carteggio 4: 49. Cf. Giorgio Vasari, Le vite de' più eccellenti pittori, scultori ed architettori nelle redazioni del 1550 e 1568, eds Paola Barocchi and Rosanna Bettarini, 6 vols, in 9 (Florence: G. C. Sansoni, 1966-87), 4: 622.

17 Carteggio, 4: 216; Leonard Barkan, Transuming Passion: Ganymede and the Erotics of Humanism (Stanford, CA: Stanford University Press, 1991), 81.

18 Ervin Panofsky, Studies in Iconology: Humanistic Themes in the Art of the Renaissance, rev. edn (1939; rpt New York: Harper, 1962), 171-230, esp. 212-18.

19 On the classical versions of the myth and their reception, see James M. Saslow, Ganymede in the Renaissance: Homosexuality in Art and Society (New Haven, CT and London: Yale University Press, 1986), 1-16; Barkan, Transuming Passion, 27-40.

20 Dante Alighieri, La Divina Commedia ... col commento di Landino, ed. Piero da Figino (Venice: Pietro Quarenghi, 1497), fol. 160r. Landino's commentary was first published in 1481 , and at least eight further editions appeared before 1500 .

21 Just over a year before, an etching of Ganymede riding the eagle appeared under the legend 'In Deo laetandum' in Andrea Alciati, Emblemata (Augsburg: Heinrich Steyner, 1531), fol. B6r. See Saslow, Ganymede, 23.

22 Cf. Dante, Inf., 31.124-6; Boccaccio, Comedia delle ninfe fiorentine, 6.13-15; Landino, Commento (1497), fol. 126v; Battista Mantovano, De calamitatibus temporum, 1.867-8.

23 Charles de Tolnay, Michelangelo, 5 vols (Princeton, NJ: Princeton University Press, 1943-60), 3: 112; Baruch D. Kirschenbaum, 'Reflections on Michelangelo's Drawings for Cavalieri', Gazette des Beaux-Arts, 38 (1951), 99-110. That the two interpretations of the Tityus were complementary is defended in Saslow, Ganymede, 35-60; noting Michelangelo Buonarroti, Rime, ed. Enzo Noè Girardi (Bari: Laterza, 1960), nos. 98, 260.

24 Cf. Girolamo Bologni, Candidae, 3.1.1-8; Jacopo Sannazaro, Elegie, 2.7.63-9; Antonio Tebaldeo, Rime, 478.37-42, 572.

25 See, for example, Alexander Nagel, 'Gifts for Michelangelo and Vittoria Colonna', Art Bulletin, 79 (4) (1997), 647-68; Ruvoldt, 'Michelangelo's Open Secrets', esp. 122; Barkan, Transuming Passion, 81.

26 The classic anthropological study remains Marcel Mauss, The Gift: Forms and Functions of Exchange in Archaic Societies, trans. Ian Cunnison (London: Cohen \& West, 1966).

27 On marriage gifts: Christiane Klapisch-Zuber, 'The Griselda Complex: Dowry and Marriage Gifts in the Quattrocento', in Klapisch-Zuber, Women, Family and Ritual in Renaissance Italy, trans. Lydia G. Cochrane (Chicago: University of Chicago Press, 1985), 213-46; Jane F. Bestor, 'Marriage Transactions in Renaissance Italy and Mauss's Essay on the Gift', Past and Present, 164 (1999), 6-46. On gifts for births and baptisms: Marie Musacchio, Art and Ritual of Childbirth in Renaissance Italy (New Haven, CT: Yale University Press, 1999); Louis Haas, The Renaissance Man and His Children: Childbirth and Early Childhood in Florence, 1300-1600 (New York: Palgrave Macmillan, 1998). On gifts granted after death: Julius Kirshner, Marriage, Dowry, and Citizenship in Late Medieval and Renaissance Italy (Toronto: University of Toronto Press, 2015), 74-93, esp. 84-5.

28 Richard C. Trexler, Public Life in Renaissance Florence (Ithaca, NY and London: Cornell University Press, 1980), 323-6.

29 The examples given are of gifts offered by the Pratese merchant Francesco di Marco Datini to the notary Lapo Mazzei: Lapo Mazzei, Lettere di un Notaro a un Mercante del Secolo XIV, con altre Lettere e Documenti, ed. C. Guasti, 2 vols (Florence: Le Monnier, 1880), 1: 7, $29,148,184$, etc.

30 See, generally, Andrea Bayer (ed.) Art and Love in the Renaissance (New York: Metropolitan Museum of Art, 2008). 


\section{The Agency of the Gift-Drawing}

31 For example: Carteggio 4: 108, 188, 207; Giorgio Vasari, La Vita di Michelangelo nelle redazioni del 1550 e 1568, ed. Paola Barocchi, 4 vols (Milan and Naples: Ricciardi, 1962), 1: 118. See also William E. Wallace, 'Miscellanea Curiositae Michelangelae: A Steep Tariff, a Half Dozen Horses, and Yards of Taffeta', Renaissance Quarterly, 47 (2) (1994), 330-50; Graziano Bianchi, Michelangelo e il Nipote (Florence: La Lettere, 2001), 14, 21-2.

32 Vasari, Le vite, ed. Milanesi, 7: 726; Ascanio Condivi, Vita di Michelagnolo Buonarroti, ed. Giovanni Nencioni (Florence: Studio per Edizione Scelte, 1998), 63-4; Benedetto Varchi, Orazioni funerale di M. Benedetto Varchi, fatta e recitata da lui pubblicamente nell' essequie di Michelagnolo Buonarroti in Firenze nella Chiesa di San Lorenzo (Florence: Giunti, 1564), $35-6$.

33 Vasari, Le vite, ed. Milanesi, 7: 726: nè voleva presenti di nessumo, perchè pareva, come uno gli donava qualcosa d'essere sempre obligato a colui; Vasari, Le vite, eds Barocchi and Bettarini, 6: 112.

34 For Aretino's praise see Carteggio, 4: 82-4 (16 September 1537). On 20 January 1538, he begged for the cartoons Michelangelo usually burnt, albeit vainly (Carteggio, 4: 90-1). Feeling slighted, he penned a stinging attack on 31 October 1545 (Carteggio, 4: 215-17).

35 Mauss, The Gift; Maurice Leenhardt, Notes d'ethnologie néo-calédonienne (Paris: Institut d'Ethnologie, 1930); Documents néo-calédoniens (Paris, 1932). For a more recent discussion of this concept, see also Cecily Hilsdale, 'Gift', Studies in Iconography, 33 (2012), 171-82.

36 Jonathan Parry, 'The Gift, the Indian Gift and the "Indian Gift”, Man, new ser. 21 (3) (1986), 453-73.

37 Vasari, Le vite, ed. Milanesi, 5: 167.

38 Vasari, Le vite, ed. Milanesi, 5: 223.

39 Carlo Cesare Malvasia, Felsina pittrice. Vite de' pittori Bolognesi, ed. Giampietro Zanotti, 2 vols (Bologna: Tip. Guidi all'Ancora, 1841), 2: 5-66; Susan L. Caroselli (ed.) Guido Reni, 1575-1642 (Bologna: Nuova Alfa Editoriale, 1988), 254; Genevieve Warwick, 'GiftExchange and Art Collecting: Padre Sebastiano Resta's Drawing Albums', Art Bulletin, 79 (4) (1997), 630-46, here 632.

40 William E. Wallace, 'How Did Michelangelo become a Sculptor?', in The Genius of the Sculptor in Michelangelo's Work (Montreal: Montreal Museum of Fine Arts, 1992), 151-67, here 155-6.

41 Carteggio, 1: 35-6. Buonarroto, however, insisted on selling Strozzi the dagger: Carteggio, 1: 38. See William E. Wallace, 'Manoeuvring for Patronage: Michelangelo's Dagger', Renaissance Studies, 11 (1) (1997), 22-6.

42 Seneca, De beneficiis, 1.2: Beneficiorum simplex ratio est: tantum erogatur; si reddet aliquid, lucrum est, si non reddet, damnum non est. Ego illud dedi, ut darem.

43 On the reception of the De beneficiis, see Miriam T. Griffin, Seneca on Society: A Guide to De Beneficiis (Oxford: Oxford University Press, 2013), 164-8.

44 For example: Augustine, Ep., 153.14.

45 Augustine, De Trinitate, 4.3.19.

46 See, for example, Natalie Zemon Davis, The Gift in Sixteenth-Century France (Oxford: Oxford University Press, 2000).

47 For example: John Calvin, Inst., 3.1.4, 3.2.33, 3.11.10; Com. Gal. 2: 20. See Charles Raith II, Aquinas \& Calvin on Romans: God's Justification and Our Participation (Oxford: Oxford Uiversity Press, 2014): 97-106; J. Todd Billings, Calvin, Participation, and the Gift: The Activity of Believers in Union with Christ (Oxford: Oxford University Press, 2007).

48 Beneficio di Cristo, 4, ed. G. Paladino, Scrittori d'Italia: Opuscoli e lettere di riformatori italiani del Cinquecento, 2 vols (Bari, 1913), 1: 26-7.

49 Benedetto Varchi, Seneca De Benefizii, tradotto in volgar fiorentino (Florence: Lorenzo Torrentino, 1554), 4. See also Alexander Nagel, 'Gifts for Michelangelo and Vittoria Colonna', Art Bulletin, 79 (4) (1997), 647-68, here 651.

50 Nagel, 'Gifts for Michelangelo and Vittoria Colonna'.

51 Carteggio, 4: 120.

52 Some of the most intriguing letters of this sort were written by Vittoria Colonna. See Abigail Brundin, Vittoria Colonna and the Spiritual Poetics of the Italian Reformation (Aldershot: 
Ashgate, 2008), 101-32; Marjorie Och, 'Vittoria Colonna and the Commission for a Mary Magdalen by Titian', in Beyond Isabella: Secular Women Patrons of Arts in Renaissance Italy, eds D. G. Wilkins and S. E. Reiss (Kirksville, MO: Truman State University Press, 2001), 193-225, esp. 212-13.

53 Carteggio, 4: 2: Sarebbe lecito dare il nome delle cose che l'uomo dona, a chi le riceve ma per buon rispecto non si fa in questa.

54 On the role of privacy, see Ruvoldt, 'Michelangelo's Open Secrets'.

55 Vasari, La vita, ed. Barocchi, 1: 125: nel suo dire molto coperto et ambiguo, avendo le cose sue quasi due sensi.

56 On 'secondary agency', see, for example, Alfred Gell, Art and Agency: An Anthropological Theory (Oxford: Clarendon Press, 1998), 36-51.

57 Michelangelo's play of assurance extended even to chiding Tommaso for doubting his love: Carteggio, 4: 26.

58 Carteggio, 4: 36 (August 1533).

59 Carteggio, 4: 13 (12 July 1533); 4: 25 (26 July 1533); 4: 32 (2 August 1533); 4: 40-1 (16 August 1533); 4: 42-3 (23 August 1533); 4: 48 (30 August 1533); 4: 50 (6 September 1533); 4: 56 (18 October 1533).

60 James Saslow, “'A Veil of Ice between My Heart and the Fire”: Michelangelo's Sexual Identity and Early Constructions of Homosexuality', Genders, 2 (1998), 77-90, here 82-3.

61 Michelangelo, Rime, 83.5-6: E se 'l vulgo malvagio, isciocco e rio, / di quel che sente, altrui segna e addita....

62 Michelangelo, Rime, 58.9-11:

Dunche, oilmè! come sarà udita

la casta voglia che 'l cor dentro incende

da chi sempre se stesso in altrui vede?

63 Michelangelo, Rime, 58.12-14.

64 Michael Rocke, Forbidden Friendships: Homosexuality and Male Culture in Renaissance Florence (Oxford: Oxford University Press, 1996), 227-36, 243-52; John K. Brackett, Criminal Justice and Crime in Late Renaissance Florence, 1537-1609 (Cambridge: Cambridge University Press, 1992), 131.

65 Saslow, Ganymede, 88-9, 150-4, 171-2, 231 note 50, 235 note 1; Luis Crompton, Homosexuality and Civilization (Cambridge, MA: Belknap Press of Harvard University Press, 2009): 264-5; Jacques Mesnil, Botticelli (Paris: Albin Michel, 1938), 98, 204; Luca Beltrami, Documenti e memorie riguardanti la vita e le opere di Leonardo da Vinci (Milan: Treves, 1919), 4-5; Luigi Greci, Benvenuto Cellini nei delitti e nei processi fiorentini (Turin: Fratelli Bocca Editori, 1930).

66 Michelangelo, Rime, 251.1-4:

Nel dolce d'una immensa cortesia,

dell'onor, della vita alcuna offesa

s'asconde e cela spesso, e tanto pesa

che fa men cara la salute mia.

67 Condivi, Vita di Michelagnolo, ed. Nencioni, 62; Vasari, Le vite, ed. Milanesi, 7: 223, 271-2. Michelangelo's great-nephew even changed the genders in any verses that appeared to express love for a man in preparing the editio princeps of his poetry: Michelangelo Buonarroti, Rime ... Raccolte da Michelagnolo suo nipote (Florence: Giunti, 1623).

68 Carteggio, 3: 444: Leggite il cuore e non la lectera, perché 'la penna al buon voler non può gir presso' Quoting Petrarch, Canz., 23.91.

69 See Albert J. Rivero, 'Petrarch's "Nel Dolce Tempo de la Prima Etade"', MLN, 94 (1) (1979), 92-112; Michelangelo's use of this canzone is discussed at Deborah Parker, Michelangelo and the Art of Letter Writing (Cambridge: Cambridge University Press, 2010), 116.

70 Carteggio, 3: 445-6: Penso bene, anzi son certo che de la affettione che mi portate la causa sia questa, che, essendo voi virtuosissimo, o per dir meglio essa virtù, sete forzato amar coloro che di essa son seguaci e che l'amano, tra li quali son io - et in questo, secondo le mie forze, non cedo a molti. 


\section{The Agency of the Gift-Drawing}

71 Carteggio, 3: 446: Vi prometto bene ... ché mai portai amore ad huomo più che ad voi, né mai desiderai amicitia più che la vostra... Spero bene, se [fortuna] non mi vuole di nuovo cominciare a tormentare, tra pochi giorni esser guarito et venire a fare il mio debito in visitarvi, se a quella piacerà. In questo mezo mi pigliarò almanco doi hore del giorno piacere in contemplare doi vostri desegni che Pier Antonio me à portati, quali quanto più li miro, tanto più mi piacciono.

72 Carteggio, 4: 1: mi reputerei e direi in disgratia del cielo e della terra, se per la vostra non avessi visto e creduto Vostra S[ignori] a accectare volentieri alcune delle opere mie.

73 Carteggio, 3: 445: vi rispondo che non erano bastanti fare che $u[n]$ buomo eccellentissimo come voi e senza secondo, nonché senza pari, in terra, desiderasse scrivere a un giovane appena nato al mondo e, per questo, quanto si può essere ingnorante.

74 Benedetto Varchi, Liber carminum, ed. A. Greco (Rome, 1969).

75 Carteggio, 4: 1: Enon che appena [mi parete] nato, come in essa di voi mi scrivete, ma stato mille altre volte al mondo...

76 For example: Petrarch, Canz., 200.5-8.

77 Petrarch, Canz., 203.9-11.

78 Petrarch, Canz., 44.12-14; cf. Canz., 164.12-14, 172.12, 281. Note that he also shed tears a mille a mille: Canz., 55.7.

79 For example: Petrarch, Canz., 264.1-8.

80 Petrarch, Canz., 21.1-3:

Mille fiate, o dolce mia guerrera, per aver co' begli occhi vostri pace v'aggio proferto il cor...

Trans. from Petrarch's Lyric Poems: The Rime Sparse and Other Lyrics, trans. and ed. Robert M. Durling (Cambridge, MA: Harvard University Press, 1976), 56.

81 For what follows, see Brundin, Vittoria Colonna, 102-7.

82 Carteggio di Vittoria Colonna, ed. Ermanno Ferrero and Giuseppe Müller (Turin: Ermanno Loescher, 1889), 203.

83 Carteggio di Vittoria Colonna, 200-2. Despite its position, this letter was certainly written after the aforementioned missive from Marguerite: Pierre Jourda, Répertoire analytique et chronologique de la correspondance de Marguerite d'Angoulême: duchesse d'Alençon, reine de Navarre (1492-1549) (Paris: Champion, 1930), nos. 799-800. 


\title{
8 Distributing Dürer in the Netherlands \\ Gifts, Prints and the Mediation of Fame in the Early Sixteenth Century
}

\author{
Jaya Remond
}

On 12 July 1520, Albrecht Dürer, accompanied by his wife Agnes, left Nuremberg for Antwerp, to obtain confirmation of his annual pension from Charles V, initially awarded by Maximilian I. Dürer arrived in Antwerp in August 1520 and left the Netherlands in July $1521 .{ }^{1}$ Based in Antwerp for most of his stay, he took trips to Brussels, Mechelen, Bruges and Zealand. The purported goal of the journey - the renewal of the imperial pension - is in fact mentioned only a few times in the artist's travel notes, the originals of which are lost but survive in the form of two later copies. ${ }^{2}$ Dürer's notes are usually referred to as a Tagebuch or diary, although they can be thought of more as a hybrid of cashbook and travel record, written in a precise, simple and somewhat dry language. ${ }^{3}$ The report of Dürer's various expenses and distribution of artworks forms the core around which his text is organised.

In his diary, the artist comes across as a dynamic entrepreneur, eager to circulate his art. Sculptors or painters they may have been, but Renaissance artists in Nuremberg were more often than not also businessmen. ${ }^{4}$ This seems to have been particularly true of printmakers at the dawn of their craft, when selling prints had not quite become an independent profession. ${ }^{5}$ At the beginning of his career, Dürer had occasionally relied on colporteurs to distribute his prints outside of his native Nuremberg. ${ }^{6}$ He must have grown quickly dissatisfied with this mode of circulation, however, as this task was soon passed over to his mother and his wife, notably during his second trip to Italy. A fairly well-travelled artist eager to advertise his fame and talent beyond the borders of Nuremberg, Dürer could not have ignored the profit-making possibilities of Antwerp, where he settled for several months. This city, at the time the second most populous in Europe after Paris, was at the heart of a dense commercial network, and was the continent's most important hub regarding international trade and dealings in luxury goods. The gateway to most European commercial cities and even new regions of the globe, Antwerp yielded a sphere of influence of unsurpassed reach and gradually became the foremost art centre of the period. ${ }^{7}$

Dürer's diary devotes significant attention to the distribution of prints, paintings and drawings, reflecting the pivotal importance he attached to the circulation and transmission of his art. In fact, the actual number of sales represents a relatively small share in the total amount of transactions carried out in the Netherlands. Out of the 110 recorded transactions involving prints, only 25 represent actual sales, while 8 can be counted as exchanges. ${ }^{8}$ Gifts account for 77 transactions, which represent a volume of at least a few hundred objects: over 200 items, to which one must add several batches (at least 15 ) of prints. ${ }^{9}$ These records suggest that Dürer's journey was also an operation to heighten his prestige, in which the distribution of gifts played a 


\section{Distributing Dürer in the Netherlands}

crucial role. More than selling his art or ensuring his pension, Dürer sought to build and strengthen a network of relations and market his image. Prints were the artworks most commonly offered. ${ }^{10}$ Their portability, reproducibility and affordability made them ideal presents. As opposed to the paintings and drawings made during the trip, they were ready-made artefacts that could be easily and immediately handed out. ${ }^{11}$

Dürer's diary points to a heightened degree of intentionality in the distribution patterns and instrumentalisation of certain art objects. Possessing a type of agency that has long been recognised and analysed, artworks have an unusual capacity to connect people socially. ${ }^{12}$ Moreover, such artworks being given as gifts also modifies their function, as it further enhances their mediating power. For it is not just a physical shift in ownership that happens when objects are being transferred from giver to receiver: an interpersonal bond is also created in this process of transmission. Dürer's text does not provide much information about the responses of those receiving his gifts but it partly clarifies the goals behind the artist's gift-giving. Accordingly, this paper will focus on certain aspects of Dürer's dispensing of gifts, but rather than addressing matters of reception and audience, the role of the artist and his aims in gift-giving will be of central concern. A microscopic observation of Dürer's discourse as it unfolds in his diary sheds light on how the artist imbued prints with meaning, particularly when they were given as gifts- how he granted them the power to perform certain tasks. ${ }^{13}$ What are prints actually expected to do, that other artworks cannot? Of course, prints conveniently condensed and conveyed the best of the artist's skills, but I will argue that Dürer's prints were meant to achieve more than that: prints also stood for the artist's body. Indeed, gifts of artworks could fulfil many purposes, but Dürer knowingly endowed his prints with a particular kind of incarnate presence. As such, engravings, woodcuts and printed books were meant to conjure up and channel the memory of his persona as they were being given as gifts. Encapsulating the essence of Dürer's art, the medium of print became a privileged conduit for reminiscence, self-promotion and recognition.

Modern definitions of the gift describe it as a thing given voluntarily without the expectation of a payment. ${ }^{14}$ In his seminal study of gift-giving practices, Marcel Mauss argues that there is no such thing as a pure gift in so-called 'archaic' societies. ${ }^{15}$ Gifts may seem to be things innocently given, but much rather might represent the interests of the giver. As Valentin Groebner's research on public and diplomatic gifts in the cities of the Upper Rhine has shown, the same held true in medieval and early modern Europe. ${ }^{16}$ Gifts were seldom given without the hope of receiving something in return, although this expectation was not necessarily made explicit. Dürer's case confirms this fluid, if not ambivalent, notion of the gift. Even though the artist categorises his different transactions in the Netherlands meticulously, the implications of the gift are not immediately discernible. In the diary, Dürer generally uses the term geschenckt (given) to designate any transaction involving a gift, namely when an object is offered without the explicit expectation of an immediate compensation. ${ }^{17}$ For sales, Dürer usually uses the terms verkaufft (sold) or gelöst (bought), always with the mention of a price. Despite this careful semantic differentiation in the registration of transactions, the status of Dürer's gifts remains ambiguous. Gifts clearly participate in a dynamic cycle of reciprocity and hospitality, involving shared meals and counter-gifts. However, Dürer's mode of note-taking does not always follow a strict chronology, which makes it often difficult to establish an exact causal correlation between the number of shared meals, the gifts distributed to certain individuals and the many gifts Dürer himself received. 
In Dürer's mind, gifts are connected with expressions of honour and respect. Fellow artists and craftsmen in Bruges gave him gifts in a very public, material demonstration of esteem: 'They invited me to dinner, made me gifts and showed me great honour.'18 Like hospitality, gifts do not only establish a connection between givers and recipients, thereby generating a dialectic of bonding and intimacy. ${ }^{19}$ They also participate in the labelling of their givers: people are metonymically associated with the gift they offer. In this way, the gift becomes an extension of the giver. ${ }^{20}$ Thus Dürer identifies one acquaintance through the gift the latter gave him previously: 'The man in Antwerp who gave me the small head of a child is named Lorenz Sterck. ${ }^{21}$ In the case of sales, Dürer mentions the names of the buyers only a few times. One such is Sebald Fischer, his first sale, and then later Felix Hungersberg. ${ }^{22}$ The majority of his buyers remain unidentified. Gifts of prints, however, are recorded with far greater precision. Dürer is always careful to name or identify in some way the recipient of the gift. ${ }^{23}$ The greater emphasis placed on the identification of gift recipients as opposed to buyers testifies to the significance of gifts for Dürer: gifts clearly have a powerful human factor and enable a personal connection in a way that sales do not.

What does Dürer try to achieve by giving out so many gifts? For the most part, he does not explicitly mention his reasons, nor does he expand on the modes or rituals of gift-giving. It can be inferred from his travel record that most of the gifts, offered in an urban context, are private and personal rather than public and official. Dürer received many gifts from his generous friends and reciprocally gave them presents in turn. Such friends include his powerful Portuguese acquaintances from whom he received various items of exotica. ${ }^{24}$ Gifts can also express gratitude for a service. ${ }^{25}$ They can occasionally accompany gifts of other artworks or sales of prints. For example, after having sold eight gold florins' worth of prints - including a whole set of engravings - to Felix Hungersberg, Dürer gives the latter one more set of engravings as a bonus. ${ }^{26}$ In this case, the gift is used as an additional reward rather than a way of generating future sales.

Gifts of prints are also used as a way of initiating first contact with people Dürer has not seen yet in person. Thus, at the beginning of his trip, Dürer has prints sent to the sculptor Conrad Meit, whom he has not met yet, through a messenger. This print set includes two large whole sheets, Saint Jerome in his Study (Figure 8.1) and the Melencolia I, as well as several half sheets, specifically the three new Marys, Anthony and Veronica ${ }^{27}$ Similarly, before meeting Maximilian I's daughter Margaret of Austria, Dürer sends her an engraved Passion as a gift. No other artworks, drawings or paintings are used in such a way, namely as a sort of proxy for the artist's presence: only printed items, whether illustrated books or single sheets, serve this purpose throughout the duration of Dürer's trip. More than an extension of the self, prints function as a substitute for it, as the gift of prints precedes the actual introduction and meeting in person. Prints are embodied objects, much like portraits: they stand for Dürer as the vessel bearing his presence.

In this way, the gift, particularly the gift of print, is imbued with the individuality of its giver and maker, and Dürer is keenly aware of what prints can convey. He writes in his diary that he gave an engraved Passion to Margrave Johann of Brandenburg so that he would remain a presence in the Margrave's memory: 'I gave the Margrave Hansen of Brussels my letter of introduction, that my lord of Bamberg wrote, and offered him a Passion engraved in copper, so that he remembers me. ${ }^{28}$ Distributed as gifts, prints are meant to conjure up the memory of Dürer in the minds of those who receive them and evoke his absent body in a way other media evidently cannot. 


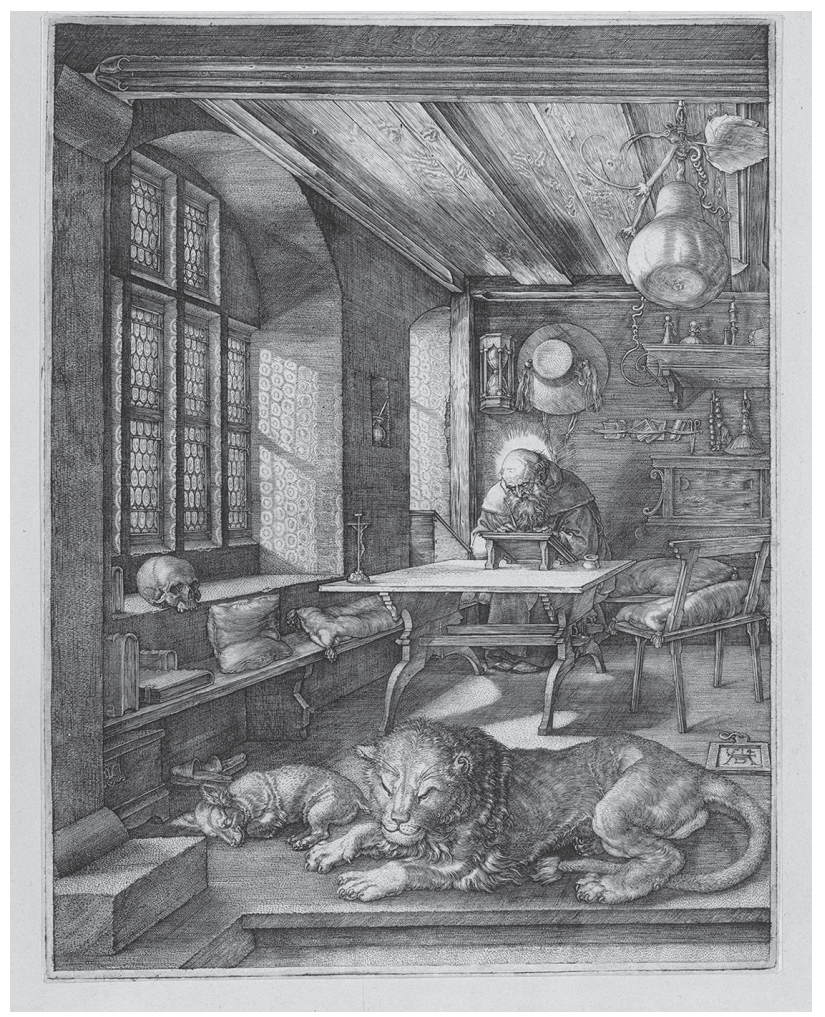

Figure 8.1 Albrecht Dürer, Saint Jerome in His Study, engraving, $248 \times 189$ mm, 1514 . Berlin, Kupferstichkabinett, Staatliche Museen zu Berlin, inv. no. 401-2.

Unlike a portrait drawing, which binds the artist to the sitter, the print is more of a free agent, liberated from the constraints of commissions. In the case of drawn portraits, which could be finished in a few hours or in one evening, Dürer often received a standard compensation of about one florin. ${ }^{29}$ While some portraits are made and given as presents, Dürer only rarely uses the terms geschenckt when he mentions such images. He usually simply writes that he made a portrait (conterfet), without adding much further information. In several places in the diary, he underlines the fact that he was given nothing in return for the portraits or the other drawings he made: 'I have made six portraits and was given nothing for those. ${ }^{30}$ While gifts of prints also trigger exchanges and counter-gifts, other media, particularly portrait drawings, seem much more embedded within mechanisms of reciprocity and financial reward. The text of the diary makes it clear that Dürer expected some sort of payment or compensation for them in a fashion that is not expressed for the prints, or at least suggested in a less obvious way.

Its reproducibility, and the ease with which it may be transported, made printed work a suitable vehicle for the circulation of an artist's fame or skills. ${ }^{31}$ Its relative affordability meant prints could be generously distributed without incurring too much of a financial loss. Registering carefully what he has given out, Dürer acts as the selfaware curator of his acts of distribution. More than portrait drawings, prints display 
the whole range of Dürer's skills, the variety of his artistry, not just in the depiction of human figures but also of landscapes, animals and objects. Prints condense and advertise the essence of his invention and imagination. In his Ricordi dated 1549, the Italian collector Sabba da Castiglione details the way Dürer's prints were appreciated and looked at, highlighting the elements that elicited visual pleasure from the viewer: 'figures', 'animals', 'perspectives', 'buildings', 'distant landscapes' and 'marvellous descriptions that would stupefy a Protogenes and an Apelles', all displayed in the sheets taken by Dürer to the Netherlands. ${ }^{32}$ Among these, Dürer privileged the dark and detailed works such as Adam and Eve (Figure 8.2), Saint Eustace, Nemesis, A Knight, Death and the Devil and Saint Jerome in his Study. ${ }^{33}$ These programmatic prints, most of which keenly demonstrate the outcome of Dürer's research on the human figure and proportions, also showcase his virtuosic representation of different textures.

Looking over Dürer's activity, can motifs and patterns of distribution be discerned? Robert Grigg sees a recurring cycle in the prints' distribution and argues for the use of pre-collated sets based on format rather than iconography. However, the volume of data is too small to establish real statistical evidence. ${ }^{34}$ Some repetitive patterns can nonetheless be observed. For instance, Dürer tends to distribute the same gift several times in a row to different recipients. During his stay in Brussels, for example, Dürer gives away the same item eight times out of nine, namely the engraved Passion, a small suite easy

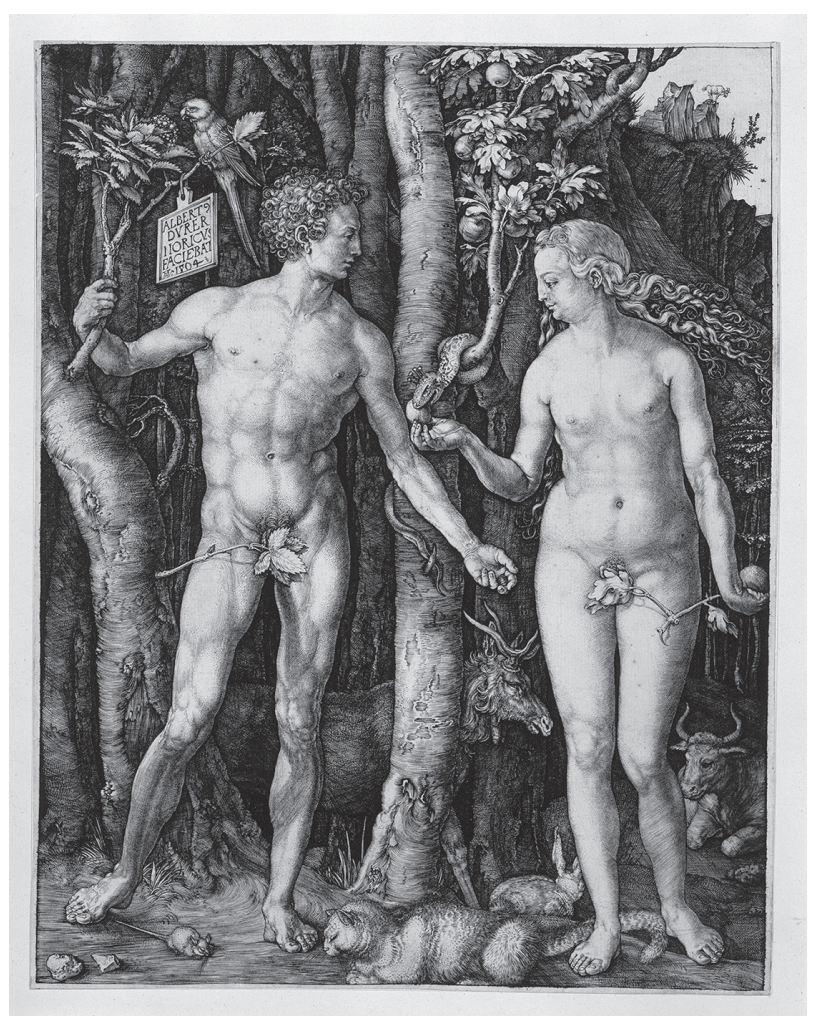

Figure 8.2 Albrecht Dürer, Adam and Eve, engraving, $250 \times 195$ mm, 1504. Berlin, Kupferstichkabinett, Staatliche Museen zu Berlin, inv. no. 101-1893. 


\section{2}

\section{Distributing Dürer in the Netherlands}

to transport and distribute. ${ }^{35}$ Dürer also distributed a significantly higher number of the Saint Jerome piece, which he must have deemed particularly representative of the best of his work. ${ }^{36}$ One thing is certain, Dürer does not exactly tailor the distribution of prints to his recipients. For instance, he gives the same print, such as the Melencolia I, to both servants and people of a higher social status, including foreign merchants, artists and members of the court. When Dürer gives packages of prints, the bundles often contain an exemplary sample of his work: a balanced number of whole sheets, half sheets, sometimes quarter sheets and books. In other words, Dürer gives a combination of items that best illustrate his artistry, in differing formats and techniques. ${ }^{37}$

Dürer was deeply conscious of the financial value of art in general, and of prints in particular. In his theoretical writings, he advises the artist 'to be sure that art is bought at a costly price; no remuneration is too high for it, and this is godly and fair. ${ }^{38}$ He was even more keenly aware of the commercial value of prints, which, made for an open market, guaranteed better payments and more fruitful long-term sales than paintings. In a letter to Jakob Heller, he famously complained about the painstaking process painting requires, and lamented that he would have made a lot more money had he decided to stick to his prints instead. ${ }^{39}$ This testifies to a pragmatic, nononsense approach to business. Ultimately, Dürer's prime motive was to make money and selling prints was the best way of achieving that goal. Even when prints are given as gifts rather than sold as products, Dürer mentions their monetary value on many occasions. By recording such information in writing, he controls and assigns value to the items, giving us an insight into his pricing system. Adam and Eve is sold for four stuivers, the woodcut Passion for three times as much, twelve stuivers. Such prices are not outrageous: Adam and Eve, for instance, costs a little more than the price of a meal, worth three stuivers. ${ }^{40}$ But Dürer's pricing scale nonetheless sets his prints apart from and above - other prints produced in Antwerp in the first decades of the sixteenth century. ${ }^{41}$ Skill is emphatically a matter of both visible and monetary value. Dürer's pricing scale reflects the fairly high standards set by the artist himself for his prints.

The emphasis placed on the value of financial prints is also evidenced by some of the exchanges made in Antwerp. On one occasion, Dürer gives a set of his 'best engravings' worth six florins to the Italian painter Thomas Vincidor who had previously offered him a gold ring worth five florins. ${ }^{42}$ Dürer's counter-gift communicates the high value of his prints: these are worth gold, and in an overbidding gesture, Dürer notes that his gift is actually worth more money than Vincidor's by one florin. Giftgiving becomes a performative operation: a way to show off his generosity and but also assert the preciousness of his own prints.

Dürer's generous gift-giving practices paint a grateful and liberal portrait of the artist, as the 'great lord' he longed to be. ${ }^{43}$ His gifts thus participated in social exercises which were performed to achieve specific yet multilayered objectives, beyond the expression of gratitude and appreciation. The act of gift-giving offered an ideal stage for self-representation, especially as giver and maker were one and the same individual. Moreover, all of Dürer's prints bore the mark of their creator in the form of a ubiquitous monogram, which asserted the presence of the artist in every object he offered. Targeting recipients from a variety of backgrounds, Dürer recognised the power of a print as an enduring means of connection: gifts of prints did not just instantly bring people together, but were also meant to perpetuate a memory of their maker over time. His prints continued to be avidly sought out and collected long after his return to Nuremberg and his death in 1528, but Dürer's influence on the reception of his art 
was after all restricted. ${ }^{44} \mathrm{He}$ could not control the trajectory taken by his artworks after these were given away: the objects then had a life of their own. Nevertheless, the text of Dürer's diary leaves little doubt about the affective and effective power that the artist himself was able to invest in his prints.

\section{Acknowledgements}

B: For their comments and help at their various stages of my research and writing, I would like to thank Prof. Jeroen Stumpel, whose graduate seminar at Harvard University gave the first impetus for this paper, as well as Sabrina Sadique, Nick Forshaw, Dr Thomas Eser, Urte Brauckmann and the anonymous reviewers.

\section{Notes}

1 Hans Rupprich (ed.), Dürer: Schriftlicher Nachlass, vol. 1 (Berlin, 1956), 151, 177. I will be referring to Rupprich's edition of the text throughout. An extensively annotated transcription is also available in Jan Veth and Samuel Muller, Albrecht Dürers niederländische Reise, 2 vols (Berlin, 1918). See also the annotated translation in J. A. Goris and Georges Marlier (trans. and ed.), Albert Dürer. Journal de voyage dans les Pays-Bas (Brussels, 1937) and English translation in Albrecht Dürer, Records of Journeys to Venice and the Low Countries (Roger Fry ed., Rudolph Tombo trans.), (New York: 1995, 1st ed. 1913), 31-99. A new translation is available in Jeffrey Ashcroft (trans. and ed.), Albrecht Dürer: A Documentary Biography (New Haven, CT: 2017), vol.1.

2 These copies are now at the Staatsbibiothek in Bamberg (JH.Msc.Art.I (iii.18)) and the Stadtarchiv in Nuremberg (S.I, L. 79, No. 15, Faszikel 18). For a brief history of both copies, see Rupprich, Dürer: Schriftlicher Nachlass, vol. 1, 146-7. The copy of the Staatsbibliothek in Bamberg can be consulted online, urn:nbn:de:bvb:22-dtl-0000001897, http://nbn-resolving.de/urn:nbn:de:bvb:22-dtl-0000001897.

3 Rupprich uses the term Tagebuch for instance, and I will refer to Dürer's record of his journey as his 'diary' throughout this paper. Dürer's scrupulous record of his expenses recalls bookkeeping practices common among merchants, as evidenced in contemporary account books such as that of Anton Tucher. See Wilhelm Loose (ed.), Anton Tuchers Haushaltbuch (1507 bis 1517) (Tübingen, 1877).

4 See Rainer Brandl, 'Art or Craft? Art and the Artist in Medieval Nuremberg', Gothic and Renaissance Art in Nuremberg 1300-1550 (New York and Munich, 1986), 56-8.

5 Jean Adhémar, 'Les Premiers éditeurs d'estampes', Nouvelles de l'Estampe, no. 6 (1972), 3. On Dürer and the print market in Northern Europe, see David Landau and Peter Parshall, The Renaissance Print, 1470-1550 (New Haven, CT: 1994), 347-58.

6 Werner Schultheiss, 'Ein Vertrag Albrecht Dürers über den Vertrieb seiner grafischen Kunstwerke', Scripta Mercaturae, 1 (2) (1969), 77-81. On Dürer's activity as an entrepreneur, see Wolfgang Schmid, Dürer als Unternehmer. Kunst, Humanismus und Ökonomie in Nuremberg um 1500 (Trier, 2003).

7 On the German presence in Antwerp, see Donald Harreld, High Germans in the Low Countries: German Merchants and Commerce in Golden Age Antwerp (Leiden, 2004). On economic phases of expansion in sixteenth-century Antwerp, see Herman van der Wee, The Growth of the Antwerp Market and the European Economy (Fourteenth-Sixteenth Centuries) (The Hague, 1963). On the development of the art market in Antwerp, see Dan Ewing, 'Marketing Art in Antwerp, 1460-1560: Our Lady's Pand', Art Bulletin, 72 (4) (1990), 558-84 and Filip Vermeylen, 'Marketing Paintings in Sixteenth-Century Antwerp: Demand for Art and the Role of the Panden', in Peter Stabel, Bruno Blonde and Anke Greve (eds), International Trade in the Low Countries, (14th-16th Centuries), Merchants, Organization, Infrastructure, Proceedings of the International conference, Ghent-Antwerp 12th-13th January 1997 (Leuven and Apeldoorn, 2000), 193-213.

8 Exchanges are understood as instances during which prints are explicitly traded against other goods or items. Transactions designate sales, gift-giving and exchanges. It should be 
noted that Dürer's - sometimes non-linear - way of recording his various transactions makes it difficult to compile a precise overview.

9 Dürer does not indicate the number of prints contained in each one of these sets, which are simply referred to as 'prints' (Kunst or artworks, understood to be prints).

10 Other media and objects (such as drawings and paintings) have been covered in the following publications: Gerd Unverfehrt, Da sah ich viel köstliche Dinge: Albrecht Dürers Reise in die Niederlande (Göttingen, 2007); Dagmar Hirschfelder, 'Dürers Bildniszeichnungen der niederländischen Reise als biografische Zeugnisse', in G. Ulrich Großmann, Almuth Klein and Petra Krutisch (eds), The Challenge of the Object/Die Herausforderung des Objekts, vol. 3 (Nuremberg, 2013), 1031-5; Jeffrey Chipps Smith, 'Albrecht Dürer as Collector', Renaissance Quarterly, 64 (1) (2011), 1-49.

11 By comparison, Dürer mentions 107 portrait drawings and 21 paintings, most of which were sold or given as gifts. See note 10 .

12 I refer essentially to Alfred Gell's concept of agency, which acknowledged and theorised the ability of artworks to 'influence' and connect viewers. Gell viewed artworks primarily as 'a system of action, intended to change the world rather than encode symbolic propositions about it.' In this '“action”-centred approach to art', artworks play a dynamic, powerful role as social agents. Far more than just material entities, they function as persons, as devices for 'securing the acquiescence of individuals in the network of intentionalities in which they are enmeshed'. See: Alfred Gell, Art and Agency: An Anthropological Theory (Oxford and New York, 1998), 6-7; Alfred Gell, 'The Technology of Enchantment and the Enchantment of Technology', in Jeremy Coote and Anthony Shelton (eds), Anthropology, Art and Aesthetics (Oxford: Clarendon Press, 1992), 43.

13 On agency and response, and for a useful criticism of Gell, see Caroline van Eck, 'Living Statues: Alfred Gell's Art and Agency, Living Presence Response and the Sublime', Art History, 33 (4) (2010), 642-59.

14 This is, for instance, the definition given by the New Oxford Dictionary of English (Oxford, 1998) ('a thing given willingly to someone without payment; a present'), although the supposed absence of expected reciprocity may be questioned in modern and contemporary gift-giving as well. On modern gifts, see Frank Adloff, 'Beyond Interests and Norms: Toward a Theory of Gift-Giving and Reciprocity in Modern Societies', Constellations: An International Journal of Critical and Democratic Theory, 13 (3) (2006), 407-27.

15 Marcel Mauss, 'Essai sur le don: Forme et raison de l'échange dans les sociétés archaïques,' Sociologie et Anthropologie (Paris, 1973, first published in 1923-4 in L'Année Sociologique), 149-279. Malinowski coined the notion of 'pure gift'. See Bronisław Malinowski, Argonauts of the Western Pacific (London, 1922), 176. In De Beneficiis, Seneca stresses that one should continue to make gifts even if they are not returned: gifts cannot be dependent on the possibility of a future compensation. See Seneca, De Beneficiis, book I, in John W. Basore (trans.), Moral Essays, vol. III (Cambridge, 1935). For a general overview on gifts, see Hirokazu Miyazaki, 'Gifts and Exchange', in Dan Hicks and Mary C. Beaudry (eds), The Oxford Handbook of Material Culture Studies (Oxford, 2010), 246-64.

16 Valentin Groebner, Gefährliche Geschenke. Ritual, Politik und die Sprache der Korruption in der Eidgenossenschaft im späten Mittelalter und am Beginn der Neuzeit (Konstanz, 2000); see also Felicity Heal, The Power of Gifts: Gift-Exchange in Early Modern England (Oxford, 2014).

17 Sixteenth-century Latin-German dictionaries translate Geschenck with Donum (gift), or Munus (gift, but also service, favour), Schencken with Do (give). See Johannes Fries and Robert Estienne, Dictionariolum puerorum tribus linguis Latina, Gallica et Germanica conscriptum...(Zurich, 1548), 216; Josua Maaler, Die teütsch Spraach: alle Wörter, Namen und Arten zuo reden in hochteütscher Spraach,... (Zurich, 1561), fol. 349 and v, Johannes Fries, Novum dictionariolum puerorum Latinogermanicum \& e diverso Germanicolatinum ... (Zurich, 1568), 806.

18 ... must mit ibnen zu nacht essen, schenckten mir und machten kunstschafft und thetten mir groß ehr. See Rupprich, Dürer: Schriftlicher Nachlass, vol. 1, 168. Similar receptions take place earlier in Antwerp and later in Ghent. On the performance of exchanges, gratitude and reciprocity during Dürer's trip in a formal setting, see Dagmar Eichberger, 'Dürer and the Netherlands: Patterns of Exchange and Mutual Admiration', in Larry Silver and Jeffrey Chipps 
Smith (eds), The Essential Dürer (Philadelphia, 2010), 149-65, and Heike Sahm, Dürers kleinere Texte: Konventionen als Spielraum für Individualität (Tübingen, 2002), 146-57.

19 Seneca and Erasmus underlined the connection between gifts and friendship. On this 'language of friendship' created by gift-exchange, see Natalie Zemon Davis, 'Beyond the Market: Books as Gifts in Sixteenth-century France', Transactions of the Royal Historical Society, 33 (1983), 77 and following, and Natalie Zemon Davis, The Gift in Sixteenth-Century France (Madison, WI, 2000), 20, 36.

20 On gifts as a 'spatiotemporal extension of the self' see Nancy D. Munn, The Fame of Gawa: A Symbolic Study of Value Transformation in a Massim (Papua New Guinea) Society (Cambridge, 1986), 11.

21 A painted head on canvas. 'Der man zu Antorff, der mit das kindsköpfflein geschenckt hat, der haißt Lorencz Stärck.' See Rupprich Dürer: Schriftlicher Nachlass, vol. 1, 152, 156 and endnote 131.

22 Ibid., 152, 157.

23 For instance, one gift recipient is identified based on his social standing, as a 'young count', ibid., 160.

24 Joao Brandao, factor of Portugal, and his secretary Rodrigo Fernandez d'Almada thus received generous gifts of prints. See ibid., 154; Unverfehrt, Da sah ich viel köstliche Dinge, 49, 219-20.

25 At least seven transactions can be identified as thank-you gifts, such as the gifts presented to Joachim Patenier (who lent Dürer colours), Patenier's servant and the servant of Dürer's cousin. See Rupprich, Dürer: Schriftlicher Nachlass, vol. 1, 152, 160.

26 Jtem der Felix, hauptmann und lautenschlager, hat mir ab kaufft ein ganczen kupffertruck und ein holcz Passion, 2 halb pögen, 2 viertel bögen, umb 8 gold gulden; so hab ich im geschenckt ein ganczen kupffertruck, ibid., 157.

27 The go-between, Gilles van Apfenauwe, receives two whole sheets, presumably as a thankyou present, ibid., 154.

28 My italics. Dürer refers here to the bishop of Bamberg. Jtem ich hab dem margraffen Hansen $z u$ Prüssel mein fürder brief geben, den mein herr von Bamberg geschrieben hat, und hab ihm ein jn kupffer gestochenen Passion geschenckt, mein dabeÿ zu gedencken. Ibid., 154.

29 Ibid., 157, 163.

30 Item 6 persohn haben mir nichts geben, die jch zu Prüssel hab conterfetet. See ibid., 156. Toward the end of the diary, Dürer mentions that, between his expenses and sales, his stay in the Netherlands was eventually not financially profitable. In the same passage, Dürer similarly complains that Margaret of Austria gave him nothing for the artworks he made and gave her. Dürer clearly anticipated a remuneration for things he had made on the spot. Jch hab in allen meinen machen, zehrungen, verkaufen und andrer handlung nachthail gehabt jm Niederland, jn all mein sachen, gegen grossen und niedern ständen, und sonderlich hat mir fraw Margareth, für das ich ihr geschenckt und gemacht hab, nichts geben, See ibid., 175-6.

31 Highlighting Dürer's artistry as a printmaker above all other skills, Erasmus, who received an engraved Passion from Dürer, marvelled at the latter's ability to express the visible and invisible world simply through the means of black lines. See Erwin Panofsky, "Nebulae in Pariete": Notes on Erasmus' Eulogy on Dürer', Journal of the Warburg and Courtauld Institutes, 14 (1/2) (1951), 36.

32 Michael Bury, 'The Taste for Prints in Italy to c.1600', Print Quarterly, 2 (1) (1985), 14.

33 Rainer Schoch, Matthias Mende and Anna Scherbaum (eds), Albrecht Dürer. Das druckgraphische Werk. Band I. Kupferstiche, Eisenradierungen und Kaltnadelblätter (Munich, London and New York, 2001), cat. 39, 32, 33, 69, 70.

34 Robert Grigg, 'Studies on Dürer's Diary of His Journey to the Netherlands: The Distribution of the "Melencolia I"', Zeitschrift für Kunsgeschichte, 49 (1986), 405.

35 Rupprich, Dürer: Schriftlicher Nachlass, vol. 1, 154-6.

36 Given fourteen times in total, Saint Jerome in His Study encapsulates the finest of Dürer's technique: it is a dark engraving, with a wealth of details and a slightly claustrophobic composition (see Grigg, 'Studies on Dürer's Diary of His Journey to the Netherlands', 403-4. On several occasions, Dürer mentions that he gave away some of his 'best' prints, suggesting a particular awareness of the quality of certain pieces (to Joao Brandao: 'die besten aus den 


\section{Distributing Dürer in the Netherlands}

viertelbogen': to Thomas Vincidor: 'meines besten gedruckten dings'; and to Christian of Denmark: 'die besten stuckh aus mein ganczen truck'). See Rupprich, Dürer: Schriftlicher Nachlass, vol. 1, 154, 158, 176.

37 See, for instance, the prints given to Jacob Banisius or Lazarus Ravensburger, ibid., 156-7, 164.

38 'Item der ander teill seit, wy jm ein söllicher v̈ber schwencklicher künstner sein künst tewer söll lassen zallen, vnd kein gelt jst zw vill dorfür, och ist es göttlich vnd recht.' Draft of the introduction and table of contents of the Lehrbuch der Malerei, see Hans Rupprich (ed.), Dürer: Schriftlicher Nachlass, vol. 2 (Berlin, 1966), 91, also discussed in Alexander Nagel, 'Art as Gift: Liberal Art and Religious Reform in the Renaissance', in Gadi Algazi, Valentin Groebner and Bernhard Jussen (eds), Negotiating the Gift: Pre-modern Figurations of Exchange (Göttingen, 2003), 337.

39 'Vnd hette ichs bißhero gethan, so wollte ich vf den heitigen tag $1000 \mathrm{fl}$. reicher sein', letter dated 26 August 1509. See Rupprich, Dürer: Schriftlicher Nachlass, vol. 1, 72.

$40 \mathrm{Ibid}$., 164. For a summary and explanation of the currencies used by Dürer, ibid., 179 note 4, and Unverfehrt, Da sah ich viel köstliche Dinge, 213, 226.

41 Jan van der Stock showed how, in 1511, the Onze-Lieve-Vrouwe-Lof Guild in Antwerp purchased a package of 300 prints for 35 stuivers, and 18 years later, a package of 200 cheap prints for 26 stuivers and 2 deniers. See Jan van der Stock, Printing Images in Antwerp. The Introduction of Printmaking in a City: Fifteenth Century to 1585, Studies in Print and Printmaking, vol. 2 (Rotterdam, 1998), 281. On the price of prints, see also Fedja Anzelewsky, 'Quelques considérations sur les prix et les formats des gravures à l'époque de Dürer', Nouvelles de l'Estampe, 64-5 (1982), 11.

42 Rupprich, Dürer: Schriftlicher Nachlass, vol. 1, 158. Dürer also notes that Vincidor's ring is worth potentially twice as much. See also note 36 .

43 In a letter to Willibald Pirckheimer written in Venice dated 13 October 1506, Dürer complains about the difference in treatment between Nuremberg and Venice where he is regarded with more respect: 'Hÿ pin jch ein her, doheim ein schmarotzer etc.' See ibid., 59.

44 In the 1560s, Christopher Plantin states how difficult it has become to obtain prints by Dürer. Iain Buchanan, 'Dürer and Abraham Ortelius', Burlington Magazine, 124 (957) (1982), 734-5. 
Part 4

Agency of Physical Manipulations 



\title{
9 The Early Modern Bible between Material Book and Immaterial Word
}

\author{
Wim François
}

In his book, Used Books: Marking Readers in Renaissance England from 2008, William Sherman rightly observed that 'the transcendence of their texts notwithstanding, Bibles ... are material objects, created, circulated, and used by actual people, in specific settings, for particular purposes.' Taking this fruitful insight as a starting point, this article will propose a model to study early modern Bibles from three different perspectives: (1) text and paratext, which implies a concentration on the 'transcendent' content; (2) the objective features of certain Bible editions, such as typefaces, layout, and images, among others; (3) traces of appropriation in individual copies. This threefold relationship determines the character of a certain edition or copy and may also inform the researcher about intended groups of readers, as well as its actual use. Given the timeframe in which this article is situated, the Reformation Era, speaking about the characteristics of a Bible also involves dealing with its confessional color, since confession was tremendously important in the period under consideration. ${ }^{2}$ The theoretical framework presented in this article will be illustrated through several examples of specific Bible editions. These copies are for the most part taken from the vernacular Bible tradition of the Low Countries during the sixteenth century, but the framework that we sketch can also incorporate examples from other traditions.

\section{Text and Paratext}

In order to determine the place of a particular Bible edition within the confessionalized landscape of the Early Modern Era, Church historians often use a kind of checklist of biblical passages that are liable to a confessionally-colored rendering and that facilitate the scholar in situating an edition within a determined camp. One of the most famous examples concerns the translation of Romans 3: 28 which reads 'For we account a man to be justified by faith, without the works of the law' (Douai Reims Version). Luther added the famous word 'alone' to 'faith,' to make the translation congruent to his sola fide-doctrine: 'Therefore we assume that a man is justified without the works of the law, by faith alone.' But since the word 'alone' is not to be found in the Greek original, its addition became a bone of contention between Lutherans and Catholics (and even between Lutherans and non-Lutheran Protestants), and thus an identitymarker of the former.

Apart from the translation of specific biblical passages, the paratextual materials may also display an outspoken confessional character that becomes evident through prefaces, prologues to individual Bible books, summaries above the chapters, and/ or marginal glosses. Such paratextual materials were designed to serve the specific 


\section{0}

aim for which the Bible edition was intended, be it for personal reading, following the official liturgy of the Church, or for use in the 'conventicles' of religious dissident groups. These elements deliberately steered the interpretation of the reader in a certain direction, a not so difficult task given their placement at the beginning of a book or chapter, or adjacent to the text in the margin. ${ }^{3}$ In this regard, Protestants borrowed paratextual materials from Erasmus, and of course from Luther and other Reformers, whereas Catholics chose 'orthodox' materials, such as the prologues of Saint Jerome to accompany the Bible books as found in the Vulgate. Eventually, the Catholic Church preferred a 'naked' Vulgate translation, devoid of all paratextual materials, but one made subservient to the official liturgy of the Church through the inclusion, among other elements, of a saints' calendar and a table indicating which Epistles and Gospels were to be read on each Sunday and feast day.

One last confessional marker for an edition was the choice of the biblical canon itself. Whereas Catholics accepted the extended canon as it was found in the medieval copies of their Vulgate, Luther claimed that the Old Testament books that were not included in the Hebrew Bible (but only in the Greek) should not be received as canonical. Luther relegated these 'apocrypha' to an intertestamental section between the Old and the New Testament. He even created a kind of deuterocanonical appendix within the New Testament and included Hebrews, James, Jude and Revelation in this category. He not only called into question the apostolic origin of these works, but even denounced their failure to express the core of the Gospel as the good news of salvation from sin by Christ alone. ${ }^{4}$

\section{Objective Features: Typefaces, Layout and Images}

Theories on the 'Bible as an object' have raised the question of how 'objective' features of Bibles could be used as agents of a definite confessional character and may inform us about intended readers and actual users. In this regard, attention will now be paid to particular features such as layout, typefaces, images, and other pictorial elements that translators, publishers, and printers chose for their Bible editions in order to give them a particular (confessional) character and for a certain audience. In a sixteenth-century context, the 'stakeholders' mentioned may also have taken censorship measures into account, so that a book censor could have, either directly or indirectly, been involved in its production.

Luther was particularly skillful in exploring the possibilities of a book's layout in order to instill his views into the reader's mind. As regards the canon, the table of contents from his September Testament of 1522 emphasized in a visual way that Hebrews, James, Jude, and Revelation constituted a kind of deuterocanonical appendix to the New Testament by separating them from the 'fully canonical' books of the New Testament with a large blank space and the omission of a (serial) number. ${ }^{5}$

Luther, moreover, altered the common division of the New Testament text into pericopes and, concomitantly, adapted the layout and division into paragraphs on the printed page. According to this method, he took care to put biblical verses that he wanted to highlight theologically at the beginning of a new paragraph and had them start with an indentation. Such a layout, together with the blank line it created before the text, made the passage stand out from the rest of the page, thus giving it emphasis. ${ }^{6}$ In Luther's September Testament of 1522 we see how this happens with 
the aforementioned verse of Romans 3: 28 'Therefore we assume that a man is justified without the works of the law, by faith alone.' In other words, text, paratext - see the marginal glosses - and layout serve Luther's aim, namely to instill into the minds of his readers his theology of justification by faith alone. This technique of indented paragraphs, borrowed from Luther's Bibles, was later taken over in several Dutch and other language - Bibles. ${ }^{7}$

Another interesting example is taken from the New Testament translated into Spanish by the Reformation-minded humanist Francisco de Enzinas and printed in Antwerp by Steven Mierdmans in 1543. In Romans 3, we notice that two verses that are important for the Lutheran doctrine of justification by faith alone are highlighted through the printing of key words in capital letters (Figure 9.1):

Romans 3: 22 Verdaderamente la justiçia de Dios es por la fee de Jesu Christo, para todos y sobre todos los que crein. ['And indeed the righteousness of God is by faith of Jesus Christ unto all and upon all them that believe.']

Romans 3: 28 Concluimos pues que el hombre es iustificado por la fee, sin las obras de la ley. ['Therefore we conclude that a man is justified by faith, without the deeds of the law.']

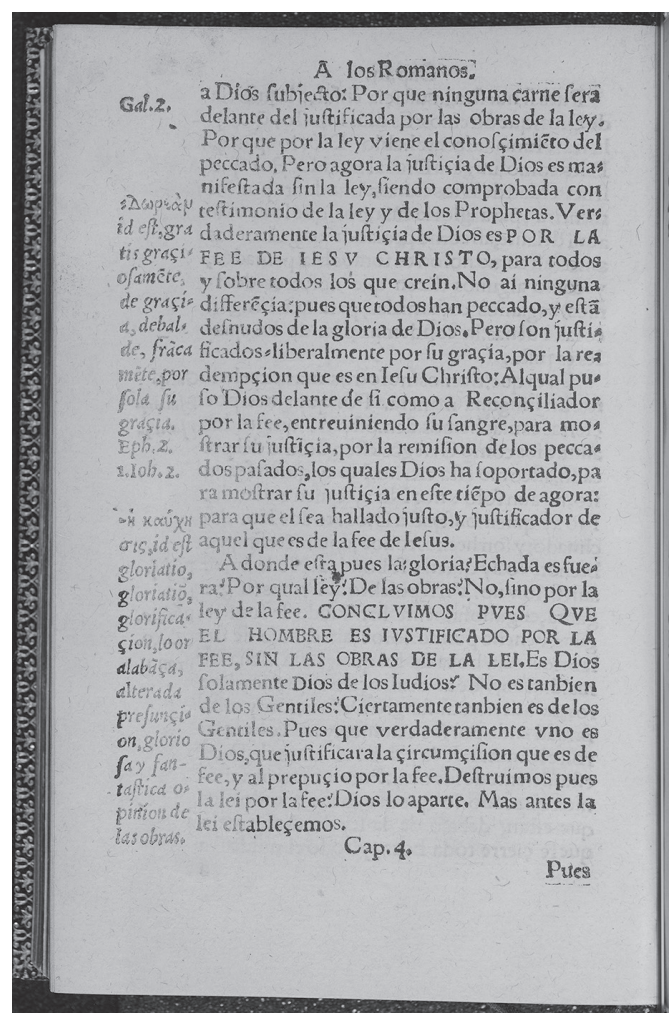

Figure 9.1 El nuevo testamento de nuestro Redemptor y Salvador Iesu Christo ...., trans. Francisco de Enzinas ([Antwerp: Steven Mierdmans], 1543), to Rom. 3. Brussels, Koninklijke Bibliotheek van België, LP 28636. 


\section{The Early Modern Bible}

Through the addition of a marginal gloss to Romans 3: 24 explaining the Greek term dorrean 'gratis, for free,' Enzinas emphasized in concurrence with the Lutheran tradition that God had offered his grace to man through the salvific death of Jesus at the cross and that man was justified by faith alone in God's graceful gift and not by the alleged merits of his works. In contrast to Luther, Enzinas did not add the word 'alone' to the translation of Romans 3: 28, but preferred - obviously for reasons of cautiousness - to highlight the same theology through more subtle means, namely the use of capital letters and the addition of marginal annotations. ${ }^{8}$

In other Bible editions, hands with pointing index fingers (maniculi) - which were already used in medieval manuscripts - were printed in the margin. ${ }^{9}$ This is, for example, the case in the Bible (both in the Old and the New Testament) printed by Willem Vorsterman in Antwerp in 1528. These manicules were now used to point to passages with a certain (theological) interest, often to texts that were important to the Reformational ideas of sola scriptura, sola gratia, and sola fide. We refer only to two examples: Romans 4: 6-7 'just as David also described the blessedness of the man, to whom God imputes righteousness apart from works: "Blessed are those whose lawless deeds are forgiven, And whose sins are covered"' (New King James); Ephesians 2: 8-9 'For by grace you are saved through faith, and that not of yourselves, for it is the gift of God; Not of works, that no man may glory.' ${ }^{10}$

It is important to notice that Vorsterman's 1528 Bible was devised as an 'orthodox' alternative to the famous Liesvelt Bible, the first edition of which was published two years earlier, but which was viewed with suspicion because of its Reformation-minded characteristics. However, several Reformation-minded passages were again included in Vorsterman's first edition, likely because one or more compositors in Vorsterman's office was sympathetic to religiously dissident ideas and deliberately ignored the corrections that were presented to them, to the great embarrassment of the 'correctors' and the printer-publisher. Therefore Willem Vorsterman brought, within a few months, in 1529, a revised version of the New Testament onto the market, with the contested biblical passages now adapted to the Vulgate, and with most of the manicules removed (Figures 9.2(a) and 9.2(b)).

Before focusing on Bible illustrations in the strict sense of the word found in Dutch Bibles, our attention is captured by an interesting pictorial element that we find in the Dutch 'Luther' Bibles published by Jacob van Liesvelt in 1535 - already mentioned above - Hansken (I) van Liesvelt in 1538 and Jacob van Liesvelt in 1542. The 'prettily arranged lines of the last paragraph of the Old Testament' are followed by a rose. This rose is also to be found on the title page of the New Testament part of the 1538 and 1542 Bibles. This was likely a subtle reference to Luther's rose, which the Reformer had adopted as his seal by 1516-17 and which he had used since 1519 as an authentication of the printed materials that went through his hands (in distinction to the many pirated editions which frequently contained mistakes). In regard to his Bible editions, the copyright mark appeared for the first time in Luther's edition of Joshua-Esther from Wittenberg in 1524 and was even printed on the title page of his edition of the Psalms from the same year. From the 1530s onward, the Luther rose turned into a mere ornamental marker. ${ }^{11}$ Van Liesvelt, who is known for his ability to take prompt advantage of all kinds of new evolutions in the world of books and religion, was eager to include the rose in his editions. ${ }^{12}$

We now turn our attention to the use of illustrations in vernacular Bibles. In this regard it should be emphasized that the large majority of the illustrations in Dutch 

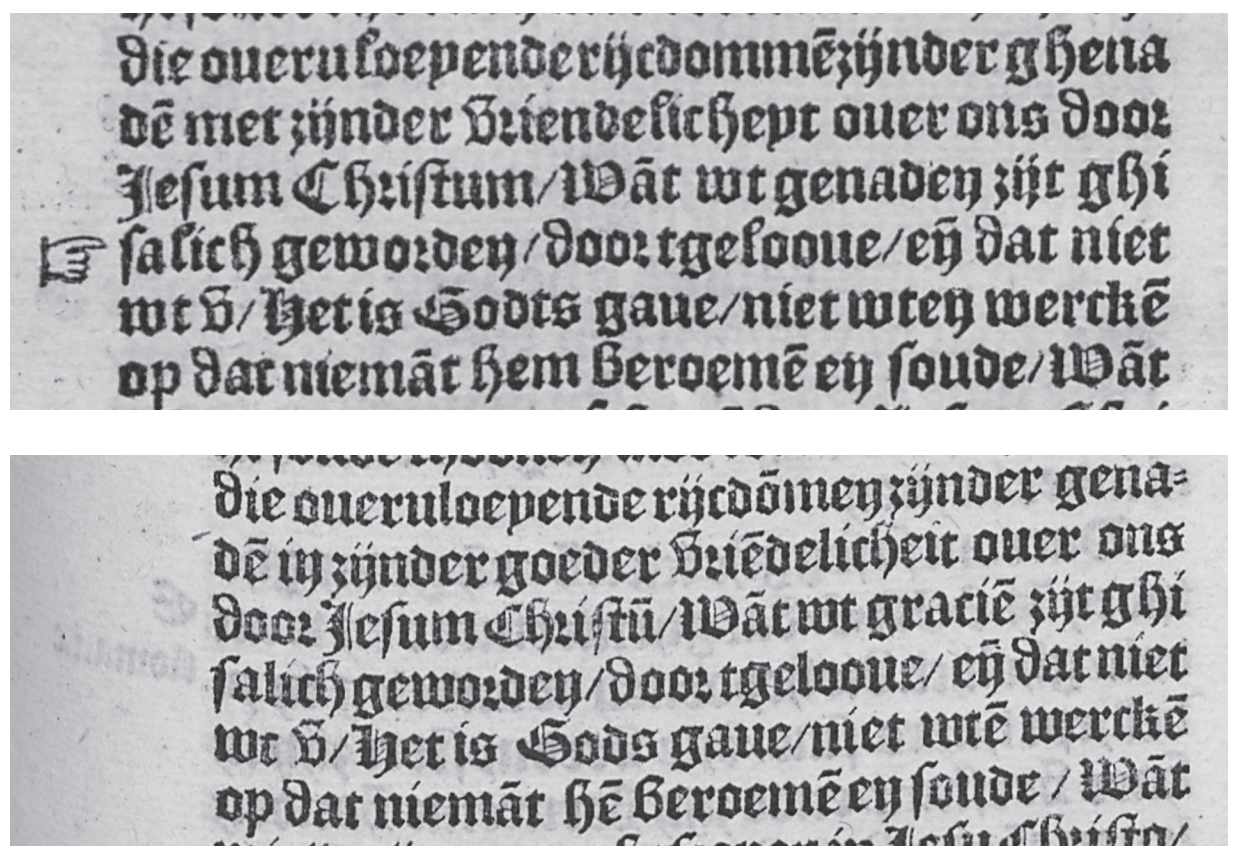

Figure 9.2(a) and 9.2(b) De Bibel Tgeheele Oude ende Nieuwe Testament... (Antwerp: Willem Vorsterman, 1528) and Tgeheele Nieu Testament ... (Antwerp: Willem Vorsterman, 1529), to Eph. 2: 8-9. Leuven, KU, Maurits Sabbe Library, GBIB P22.055.1/F\% $\mathrm{BIJB} / 1528-29$.

Bibles aim at providing the reader with a visualization of the literal meaning of the text and, as such, offer an aid to comprehend the heart of the biblical story, although the selection of elements from the narrative that are visualized is in any event a 'hermeneutical fact. ${ }^{13}$ In the context of this contribution, it is important to note that the large majority of the Bible illustrations have no confessional color and were used indiscriminately in Protestant or Catholic Bibles. With regard to the (Old Testament) illustrations included in sixteenth-century Dutch Bibles, it should, however be observed that an important part of them bear pictorial features that go back ultimately to the late Middle Ages, making them open to a typological interpretation. Three of the often copied German illustration cycles in Dutch Bibles - Erhard Schön's series for Jacob Sacon's Lyons Vulgate editions (1518-21), Hans Holbein's Icones (c.1525; first published in book form in 1538), and Hans Sebald Beham's Biblische Historien (1533) drew extensive inspiration from the so-called Cologne Bible printed by Heinrich Quentel in 1478-9, whereas the Italian Malerbi Bible published by LucAntonio di Giunta in Venice 1490 is also an important source. The illustrations accompanying the description of the Ark of the Covenant, the Tabernacle of the Desert, and Solomon's Temple go back ultimately to the pictorial tradition of the Postilla by Nicholas of Lyra (c.1270-1349). It remains an open question, however, whether, without receiving any guidance, the users of sixteenth-century Bibles were able to see all the Old Testament scenes depicted as a pre-figuration of the salutary events of the life of Christ, his mother, 


\section{The Early Modern Bible}

or the mysteries of the Church. It is also true that a part of the sixteenth-century readership, in particular those readers who were influenced by the 'new' humanist and Reformation-minded ideas, also harbored critical thoughts regarding the late medieval typological tradition. ${ }^{14}$

Whatever the case may be, in the largely Catholic Vorsterman Bible of 1533-4 and in the editions published in its wake, glosses and annotations were included in the margin to make the typological relationships of many images explicit (in addition to providing other kinds of information). ${ }^{15}$ The Catholic accents are striking, as one can see from the annotation to the picture illustrating Exodus 3, Moses before the burning bush that is not consumed. In the margin we read the annotation: 'This bush burned but was not consumed, which is a figure of the immaculate virginity of the Mother of God, Mary. ${ }^{16}$ The bush that burned without being consumed was traditionally seen as a pre-figuration of Mary and signified her conception of Jesus 'without being consumed by the flames of concupiscence' and thus without compromising her virginity. This is at least the explanation we also find in the late medieval block books, as the Biblia Pauperum and Speculum humanae salvationis. ${ }^{17}$ The word 'immaculate,' onbevleckt in Middle Dutch, may also recall Mary's Immaculate Conception, the belief that Mary was kept free from the stain of original sin from the very moment of her conception (which should not be confused with her lasting virginity). The view, however, that the burning bush was a pre-figuration of Mary's Immaculate Conception was not as widespread as the belief that it was a pre-figuration of Mary's virginity, and the view developed only gradually, when the doctrine of the Immaculate Conception became more and more accepted, with the Franciscans showing themselves to be its most zealous propagators.

At Exodus 25 we find an image of the table on which the so-called 'loaves of proposition' or 'showbread' were to be placed, an image taken from the Postilla tradition. This was of course considered as a pre-figuration of the Sacrament of the Altar. ${ }^{18}$ We do not, however, find this motif in Speculum humanae salvationis or in Biblia Pauperum. In the Middle Ages the loaves of proposition were considered to be a figure of God's nourishing Word, but in early modern Catholic exegesis, precisely in dispute with the Protestants, they were increasingly interpreted as a pre-figuration of the Sacrament of the Altar. ${ }^{19}$

There are, however, a few exceptions to the general non-confessional character of biblical illustration programs. In this regard we cannot avoid referring to the 21 illustrations of the Apocalypse which Lucas Cranach made for Luther's September Testament of 1522 and which served as an inspiration for Hans Holbein's illustration cycle for the edition of Luther's New Testament that appeared in 1523 with Thomas Wolff in Basel. It is generally known how the Beast coming out of the Abyss according to Apocalypse 11: 7 (identified by Luther with the Antichrist), the Beast spitting the unclean spirits from Apocalypse 16: 10-13, and the Whore of Babylon from Apocalypse 17: 1-6 the 11 th, 16th, and 17 th images respectively - were depicted wearing a papal tiara. Holbein had preserved the papal tiara, although in Luther's December Testament of 1522, the Duke George of Saxony, commanded that the tiara be replaced with a simple crown in order to attenuate the harsh anti-Roman character. ${ }^{20}$

Equally interesting are the 14th and 18th images, dealing with 'Angels proclaiming the day of judgment and the fall of Babylon,' and 'The burning of Babylon and a mighty angel casting a great (mill)stone into the sea,' respectively. Holbein's depiction of corrupt Babylon clearly resembles Rome and its Castle of the Holy Angel, which 
was the fortified palace of the popes in that period. It is usually accepted that the picture is a copy of the right half of the representation of Rome from the Nuremberg Chronicle by Hartmann Schedel (1493). It is striking, however, that in Germany these images were not considered as anti-Roman or, at least, their anti-Roman slant was so discrete that they were not regarded as provocative. They were not removed from the December Testament of 1522 . Even the New Testament by Hieronymus Emser that was published in 1527 by Wolfgang Stöckel in Dresden and that offered a vulgatized version of Luther's New Testament, still has the angel on the Castel Sant'Angelo, whereas the tiaras worn by the Beasts and by the Whore of Babylon were removed.

Holbein's series lies at the basis of most Apocalypse illustrations in the Dutch New Testaments and Bibles of the sixteenth century. Only a few printers, however, dared to keep the papal tiaras in the 11th, 16th, and 17th woodcuts. Among them are two early Reformation-minded Dutch New Testaments, namely Hiero Fuchs's 1525 Cologne edition and Hans (I) van Ruremund's edition published in Antwerp in the same year and in which the same woodcuts were used. ${ }^{21}$ Apart from the New Testament editions of Fuchs and Van Ruremund, the complete Bible edition of Henrick Peetersen van Middelburch from 1535 and his New Testament of 1538 also contain an image of the Whore of Babylon wearing a papal tiara on her head (17th image), whereas the tiara had been replaced by a simple crown in the 11th and 16th images. In all other editions of Dutch Bibles or New Testaments of the said period, the papal tiaras have disappeared with the traces of the cutting away of the upper elements of the tiara often visible on the woodcuts.

Inversely, most Dutch Bible editions from the period have preserved the angel on top of the Castel Sant'Angelo-shape fortress of Babylon (14th and 18th pictures), as was the case in Germany. However, Willem Vorsterman decided to remove it. In his thoroughly Catholic Dutch New Testament of August 1530, Vorsterman had already removed the angel from the 14th print, whereas the 18th still retained it (the woodblocks used are borrowed from Jan van Ghelen in 1528). In the New Testament of November 1530, the angel was removed even from both pictures of the castle (the woodblocks are those Vorsterman had already used for his French New Testament of 1529). In the complete Bible editions of 1532 and later, the same Apocalypse woodblocks were once again used, thus displaying Babylon without an angel on the top of its castle. It is beyond doubt that Vorsterman, who aimed at bringing good Catholic Bibles onto the market, wanted to avoid every identification of the Castle depicted in his Bible with the Castel Sant'Angelo in Rome. For this was what the Reformers had aspired to, namely identifying apocalyptic Babylon from John's Revelation with contemporary Rome, the see of the pope whom they considered to be the Antichrist. ${ }^{22}$

Apart from the tiara-wearing pope, Reformation-minded Bibles show us pictures of monks and clergy in very unflattering circumstances, which may be viewed as an anticlerical sneer (a phenomenon that was not at all unfamiliar to the inhabitants of the Low Countries, since the late Middle Ages onwards).$^{23}$ In the literature on illustrations in Dutch Bibles, other alleged examples of confessionally inspired images have been put forward, although such a confessional reading can rarely be maintained after serious scholarly consideration. ${ }^{24}$ What remains is the overall impression that Bible illustrations are, to an important degree, confessionally neutral and designed to 'create a summarization of the biblical narratives in immediate and clearly observable images of the story.' 25 The watershed distinction between Catholic and Protestant Bibles in the Low Countries occurred in the 1550s, when the use of images disappeared almost 


\section{6}

completely from Protestant Bibles, which only preserved the didactic or explanatory prints showing the Temple and the Tabernacle, as well as some maps of the Holy Land. Catholic Bibles, in contrast, continued to be copiously illustrated. ${ }^{26}$

\section{Traces of Appropriation in Individual Copies}

In a last part of this article, we will leave the focus on how translators, publishers, and printers - whether or not in debate with the censors - conceived the production of a Bible translation in order to study how owners and users appropriated the work. The appropriation of a Bible book may be described according to a tripartite division, namely users' traces, owners' marks, and content-related interventions such as marginal notes and censorship measures. ${ }^{27}$ The question of whether a book was actually read requires one to pay attention to objective users' traces: pages well-thumbed at the edges, irregular edges to the text-block or, only occasionally, traces of fire which may have been caused by reading by candlelight. There are even examples of books containing food stains.

Apart from the 'objective' traces that users left behind, they often deliberately introduced all kinds of annotations. The first and most common inscriptions are data of provenance and ownership notes. The owners of Bibles may have been convents and monasteries, individual friars and sisters, clerics living in the world, or laymen and women. In some Bible copies, we even find genealogies in the sense that important family events, such as births, marriages, and deaths, are recorded. These are often found on a blank leaf at the beginning or end of the book, or in between the Old and New Testaments. In addition, references to what the owners saw as important historical events have been written down, thus marking their own place in history (Figure 9.3). ${ }^{28}$ Many Bibles that were originally in lay hands eventually came into the possession of monasteries when they were donated or bequeathed.

Furthermore, we find copies containing extensive underlining, often crudely executed, selective marginalia, as well as larger annotations that may inform us about the theological ideas of the owner and their confessional color - provided that we are able to get through the paleographical nightmare (Figure 9.4). ${ }^{29}$ In a heavily annotated copy of the 1533-4 edition of Vorsterman's Bible, we see how the reader has written an additional note to the marginal gloss giving a typological explanation of 'Moses before the burning bush.' This note reads: 'Inviolate, intact, and chaste art Thou, O Mary'30 (Figure 9.5). Here, indeed, 'printed marginalia [are] imitated or elaborated in handwritten annotations. ${ }^{31}$

In some cases, even extra pages were added to make the copy usable for a specific aim the owner had in mind. The Maurits Sabbe Library of the University of Leuven preserves a remarkable copy of the Catholic New Testament printed in Leuven in 1548. As is usually the case with books of this type, the text of the New Testament was followed by the text of the Epistle readings taken from the Old Testament that were read during mass (in this instance with an emphasis on the lessons of Lenten Fast). However, a beautiful handwritten quire has been added containing the Dutch text of several Old Testament lessons that were not included in the printed part. The quire has been immediately (and not at a later stage) bound together with the printed work, with a book binding which is still the original one and is stamped with an image of the Habsburg Emperor Charles V. ${ }^{32}$ In this way the booklet was tailored even more to the need of the owner or user to help him or her to follow the scriptural readings at mass. 


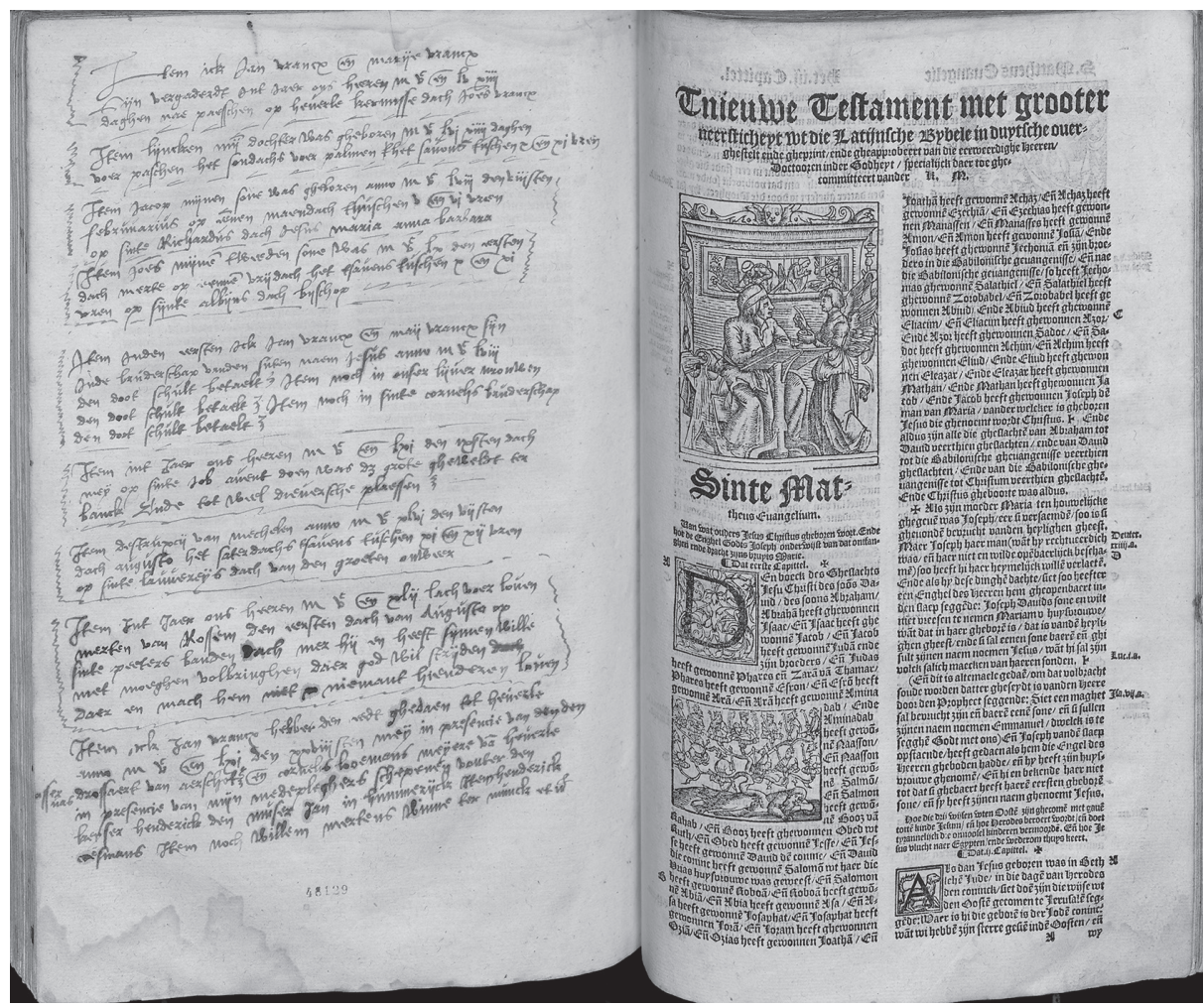

Figure 9.3 De Bibel inhoudende het oude ende nyeuwe Testament ..., trans. Nicholas van Winghe (Antwerp: Widow Henrick Peetersen van Middelburch for Marie Ancxt, 1560). Leuven, KU, Maurits Sabbe Library, GBIB P22.055.1/F\%/ $\mathrm{BIJB} / 1560$.

Later, in 1640, the book was in the possession of a religious sister named Elisabeth de Gru(u)tere. ${ }^{33}$

In rare cases, we even find interesting examples of how texts and images in Bibles were subject to active censorship. In a copy of Liesvelt's 1535 Bible, preserved in the Maurits Sabbe Library, we see how the Lutheran addition 'alone' has been carefully scratched out from Romans 3: 28.

The Maurits Sabbe Library also preserves a Dutch Catholic Bible, translated by the Carmelite Alexander Blanckart and printed by Jaspar van Gennep in Cologne in 1547-8. The title page border shows us a variation to a renowned picture by Anton Woensam, called 'of Worms' $(\dagger 1541)$ and is vividly colored by an unidentified user (Figure 9.6). On top of the page border we find a variation to the famous staircase of grace. Jesus is showing the wounds in his hands and his side to the Father, who sits enthroned as a severe judge (see the accompanying passages from Zacharias 1: 15 'And I am angry with a great anger with the nations,' and Deuteronomy 32: 23 'I will spend my arrows among them' [DRV]). Jesus' act should be seen as an act of intercession on behalf of a condemned mankind. Just as God created Eve from Adam's rib depicted below on the page border - Jesus has opened the possibility for mankind 


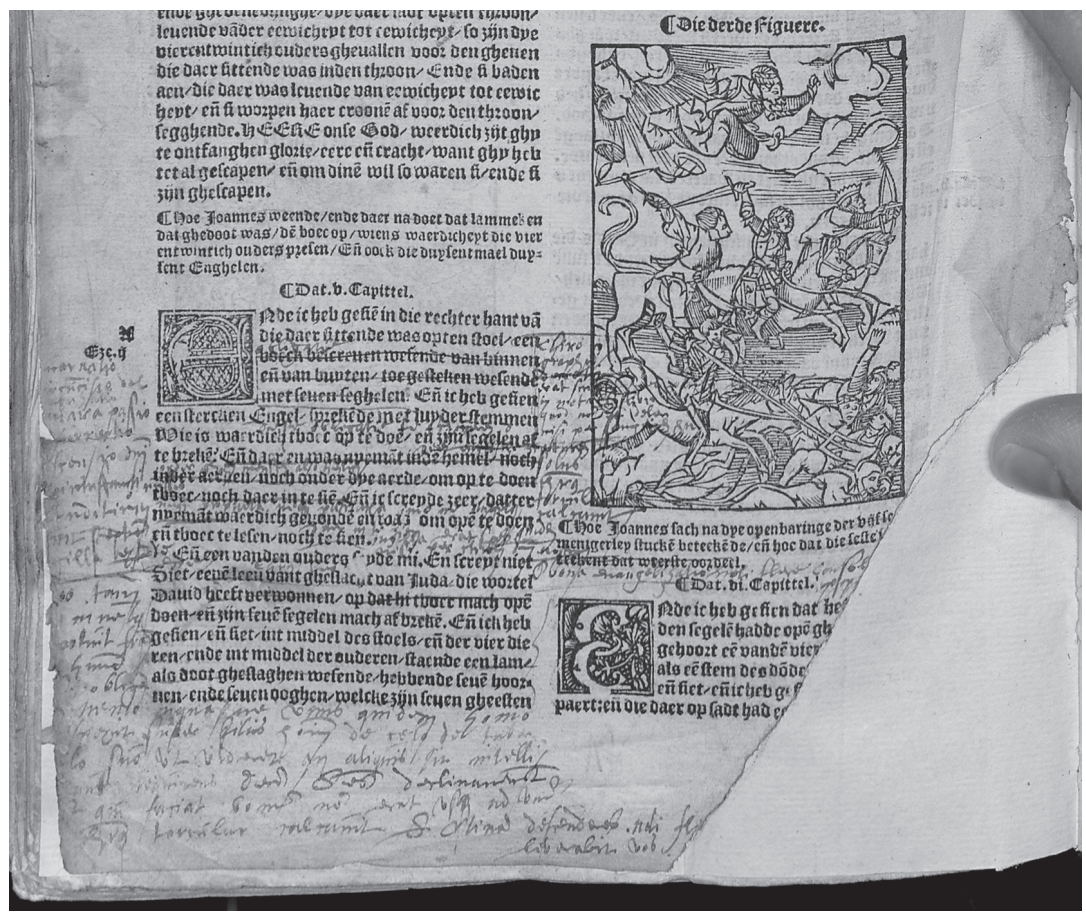

Figure 9.4 Den Bibel Tgeheele Oude ende Nieuwe Testament... (Antwerp: Willem Vorsterman, 1533-4), to Apo 5. Leuven, KU, Maurits Sabbe Library, GBIB $\mathrm{P} 22.055 .1 / \mathrm{F}^{\circ} / \mathrm{BIJB} / 1533-34$.

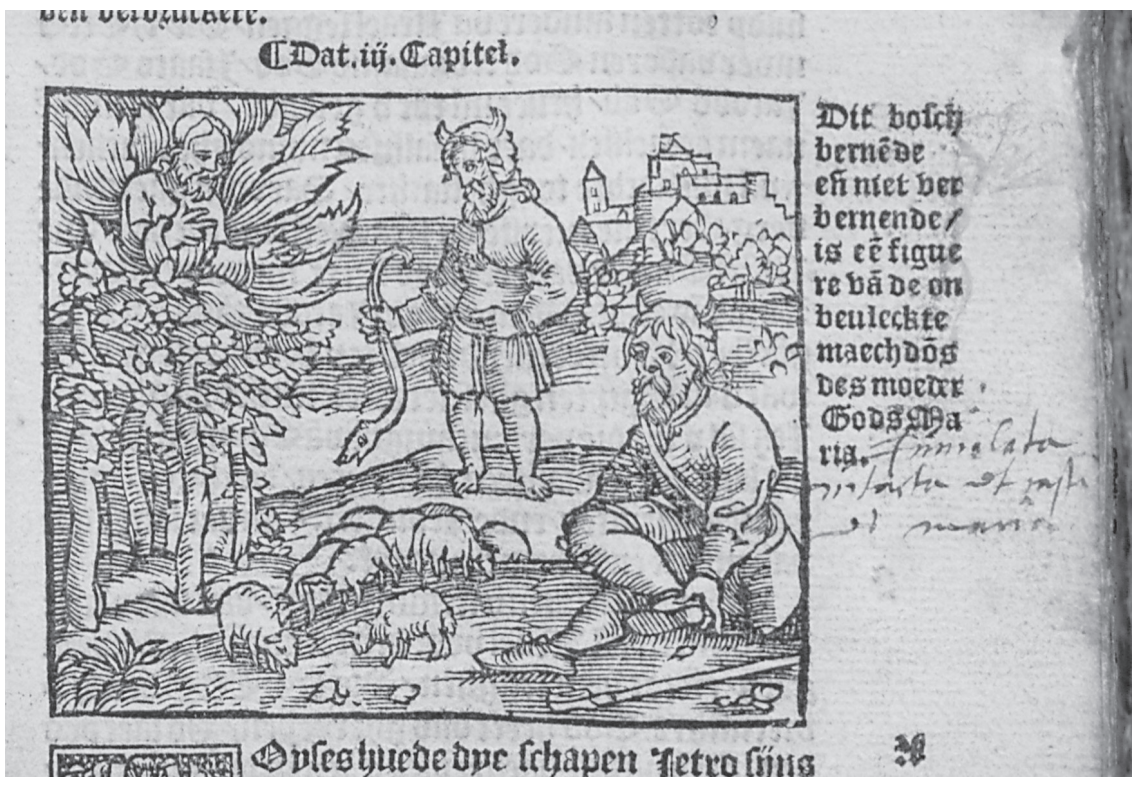

Figure 9.5 Den Bibel Tgeheele Oude ende Nieuwe Testament... (Antwerp: Willem Vorsterman, 1533-4), to Ex. 3. Leuven, KU, Maurits Sabbe Library, GBIB $\mathrm{P} 22.055 .1 / \mathrm{F}^{\circ} / \mathrm{BIJB} / 1533-34$. 


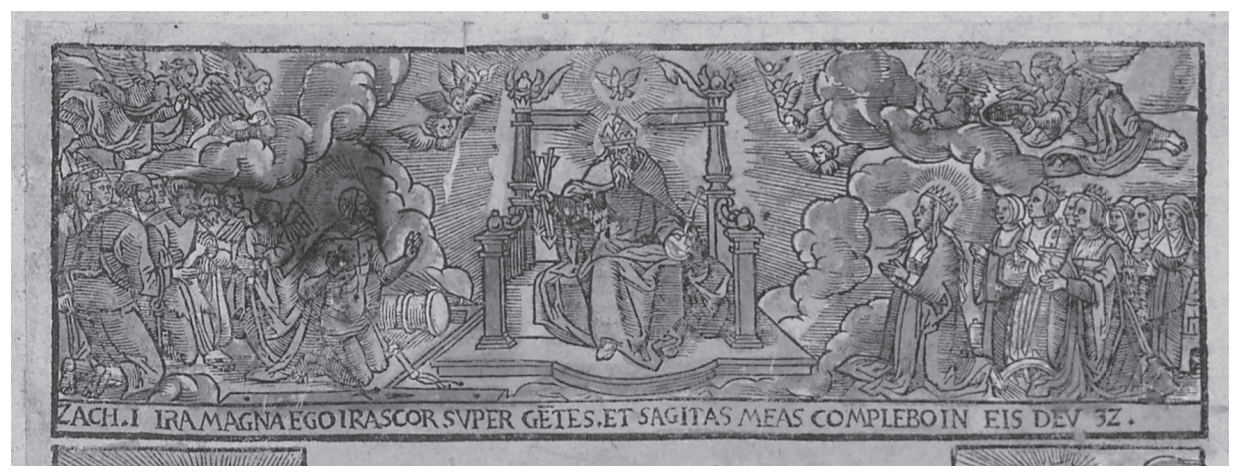

Figure 9.6 Die Bibel, wederom met grooter nersticheit oversien ende gecorrigeert ..., trans. Alexander Blanckart and Joannes Sprengel (Cologne: Jasper van Gennep, 1547-8), front page. Leuven, KU, Maurits Sabbe Library, GBIB $\mathrm{P} 22.055 .1 / \mathrm{F} / \mathrm{BIJB} / 1548$.

to be restored and saved through the open wounds in his hands and his side. On the other side of Jesus, Mary is also implied in this act of intercession before God's throne. Apart from the fact that the title page has been colored, the presence of an inkblot just along the length of Jesus' figure is striking. This inkblot has no accidental cause, but has most probably been applied as a deliberate censure of the image. The reason is that Jesus is not at the place where He should be, namely enthroned at the right hand of God, but is depicted on a lower step, kneeling before the Father, and even on the same level as Mary. The hypothesis of a deliberate censorship is confirmed by the fate of other images of the same kind, the most famous example being the painting of the staircase of grace by Abraham Bloemaert (1564/6-51), which is currently still in the Saint-John's Cathedral in 's-Hertogenbosch (the Dutch part of Brabant). Immediately after its arrival there $c .1615$, the painting evoked the discontentment of Antonius Bruynincx, a member of the cathedral chapter. On order of the bishop of Den Bosch, Bloemaert made a pen drawing of the painting, which was sent to the Louvain theologians for further examination. The theologians did not hesitate to issue a negative assessment, for the reasons explained above. ${ }^{34}$

A last example of how users or readers may deal with books and images is to be found in a Catholic New Testament edited by the Jesuit Frans de Coster or Costerus and published in 1614 by Joachim Trognaesivs in Antwerp. The Bible was explicitly destined for the market in the Dutch Republic. In order to be acceptable to a Protestant readership, the edition did not contain images. Since the aim was to bring the Protestants of the North back to Catholicism, anti-Protestant glosses in the New Testament were included in order to convince them of the necessity of such a step. However, the Maurits Sabbe Library preserves a copy of Costerus's edition, in which lots of images are carefully inserted or glued on the relevant pages of the New Testament. The work dates from the middle of the seventeenth century and contains images from engravers such as Cornelis Galle (1576-1650), Cornelis Schut (1597-1655), Martin van den Enden (1605-73), Joannes Meyssens (1612-70), and Caspar Huberti (1619-84), among others. The aim was, of course, to adapt this New Testament for Catholic devotional practices, providing a meditative apparatus in both text and image that would nourish the soul (Figure 9.7). 


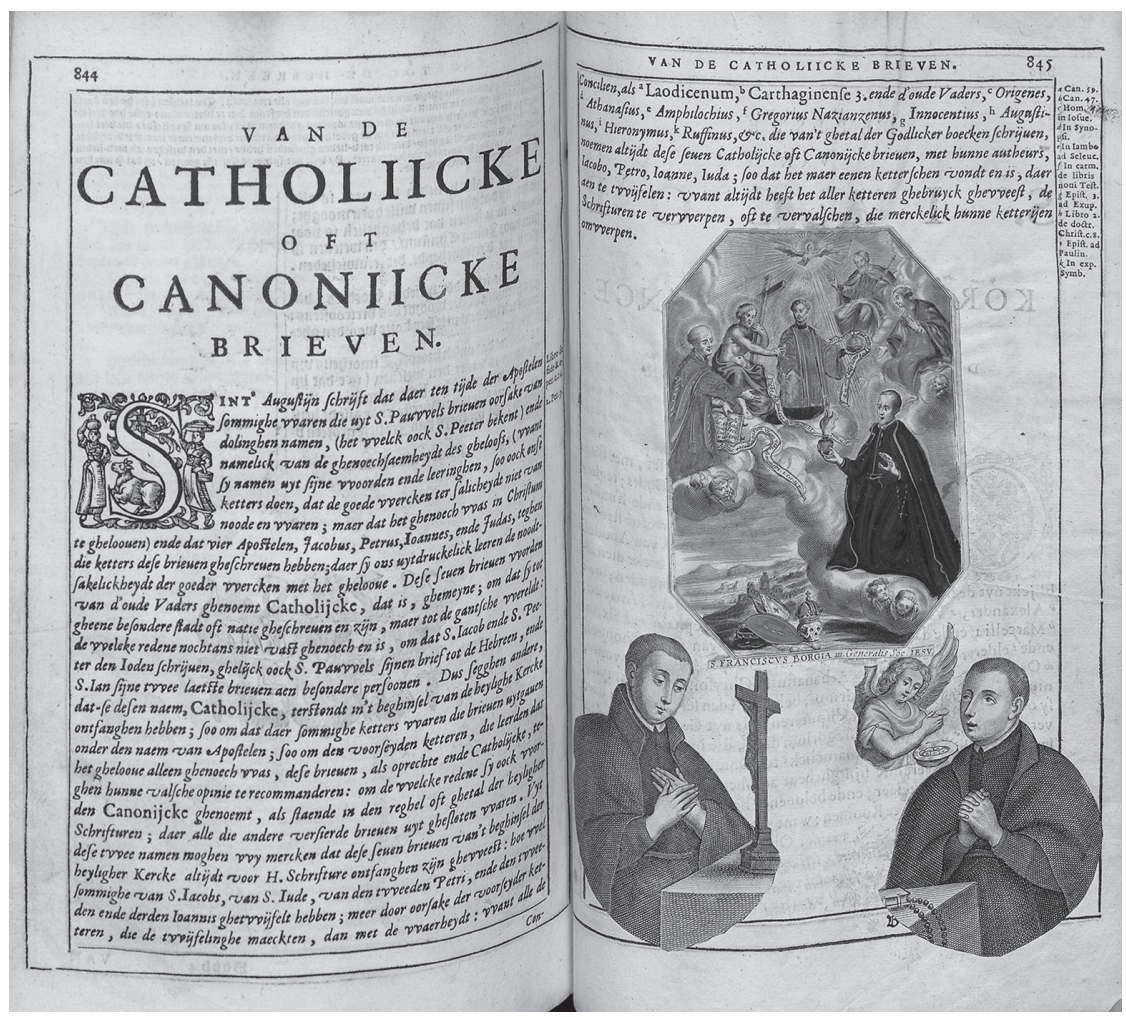

Figure 9.7 Het nieu testament onses Heeren Iesu Christi met korte uytlegghinghen ..., ed. Franciscus Costerus (Antwerp: Ioachim Trognaesius, 1614. Leuven, KU,

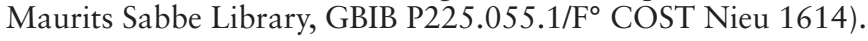

\section{Conclusion}

The study of the Bible in the Reformation should not only concentrate upon text and paratext, but should also take into account the material aspects of certain editions and even devote an increasing interest in individual copies. Indeed, the study of individual copies may inform us about who actually read a certain Bible. A complete view in this regard will require the examination of provenance and other data in a broader set of copies.

This research, however, is liable to a few methodological difficulties. For example, cheap religious books that contained the New Testament or the Epistle and Gospel readings from mass - which were often edited in an octavo, duodecimo or seidecimo format and which were intensively used and read - were often kept in use until they were completely worn out. After such intensive use, these types of books were often thrown away, with the result that they have been lost to research. ${ }^{35}$ The implication here is clear: the books that are the most fascinating for scholars interested in the social history of reading have fewer chances of survival than preciously edited books that were hardly touched. Furthermore, the books that were preserved in monasteries, and 
which were kept in public libraries following the secularization of those institutes, had more chance of survival than books owned by lay people that were constantly passed down to new generations and may have been liable to a lack of interest in some of the new owners. These methodological provisos notwithstanding, many interesting insights regarding actual readership may be expected from the examination of a larger set of individual Bible copies from the Reformation Era. ${ }^{36}$

\section{Notes}

I wish to thank Ms Jennifer Besselsen-Dunachie for her invaluable assistance in translating the text.

1 William H. Sherman, Used Books: Marking Readers in Renaissance England (Philadelphia, PA: University of Pennsylvania Press, 2008), 72.

2 Our theoretical framework is tributary to several authors, among whom Robert Darnton, 'What is the History of Books?,' Daedalus, 111 (1982), 65-83; idem, 'What is the History of Books? Revisited,' Modern Intellectual History, 4 (2007), 495-508; Donald McKenzie, Bibliography and the Sociology of Texts (London: British Library, 1986); Roger Chartier, The Order of Books: Readers, Authors, and Libraries in Europe between the Fourteenth and the Eighteenth Centuries, trans. Lydia G. Cochrane (Oxford: Polity Press, 2007); Roger Chartier, 'The Order of Books Revisited,' Modern Intellectual History, 4 (2007), 509-19.

3 Apart from confessionally colored marginal glosses, other types of printed marginalia in Bible books may claim to be more 'neutral,' such as cross-references to other biblical passages, textual variants, explanations of Hebrew and Greek source words, as well as biblical names, chronological annotations, and so on. But the mere presence of 'linguistic glosses on source words or textual variants' may not be as neutral as it looks at face value, as William Sherman has rightly observed, since "these too created a contested space on the edge of the text and revealed to the readers a multiplicity or indeterminacy in the transmission of God's Word' (Sherman, Used Books, 74). Interesting ideas on printed marginal glosses may also be found in Heidi Brayman Hackel, Reading Material in Early Modern England: Print, Gender and Literacy (Cambridge: Cambridge University Press, 2005), esp. 88-100 and 125-36.

4 Among the numerous works on Luther's Bible translations, the following are useful in the context of this article: John L. Flood, 'Martin Luther's Bible Translation in its German and European Context,' in The Bible in the Renaissance: Essays on Biblical Commentary and Translation in the Fifteenth and Sixteenth Centuries, ed. Richard Griffiths (Aldershot: Ashgate, 2001), 45-70; Mark U. Edwards Jr., Printing, Propaganda and Martin Luther (Berkeley, CA: University of California Press, 1994).

5 Edwards, Printing, Propaganda and Martin Luther, 109-31, here 113. Cf. Flood, 'Martin Luther's Bible Translation,' 54.

6 Cf. Edwards, Printing, Propaganda and Martin Luther, 122-3.

7 Frans A. Janssen, 'The Rise of the Typographical Paragraph,' in Cognition and the Book: Typologies of Formal Organisation of Knowledge in the Printed Book of the Early Modern Period, eds Karl A. E. Enekel and Wolfgang Neuber (Leiden: Brill, 2005), 9-32, at 21-4.

8 Cf. Els Agten, 'Francisco de Enzinas, a Reformation-minded Humanist with a Vernacular Dream: A Spanish New Testament,' Reformation and Renaissance Review, 14 (2012), 219-42, at 235-7. See there for further literature.

9 On the maniculi or manicules: Sherman, Used Books, 25-52, esp. 40-5.

10 Cf. Wim François, 'De Vorstermanbijbel van 1528 en later: naar een katholieke bijbel,' in De Bijbel in de Lage Landen: Elf eeuwen van vertalen, eds Paul Gillaerts et al. (Heerenveen: Jongbloed, 2015), 237-65, here 250. On the Vorsterman Bible, see also Wim François, 'The Compositors' Neglect or the True Story Behind the Prohibition of Vorsterman's Dutch Bibles,' Ephemerides Theologicae Lovanienses, 91 (2015), 239-56.

11 Dietrich Korsch, 'Luther's Seal as an Elementary Interpretation of His Theology,' in Harvesting Martin Luther's Reflections on Theology, Ethics, and the Church, ed. Timothy J. Wengert (Grand Rapids, MI and Cambridge: Eerdmans, 2004), 56-77, at 60; Haimo 
Reinitzer, Biblia deutsch. Luthers Bibelübersetzung und ibre Tradition (Wolfenbüttel: Herzog August Bibliothek, 1983), 144-7; Hans Volz, 'Das Lutherwappen als 'Schutzmarke,"' Libri, 4 (1954), 216-25.

12 Goran Proot, 'Designing the Word of God: Layout and Typography of Flemish 16thCentury Folio Bibles Published in the Vernacular,' De Gulden Passer, 90 (2012), 143-79, at 173.

13 Max Engammare, 'Les représentations de l'Écriture dans les Bibles illustrées du XVIe siècle. Pour une herméneutique de l'image imprimée dans le texte biblique,' Revue française d'histoire du livre, 64 (1995), 117-89.

14 On the decline of the interest in typological associations in the Biblia Pauperum tradition, see Jan Piet Filedt Kok, 'Een Biblia pauperum met houtsneden van Jacob Cornelisz. en Lucas van Leyden gereconstrueerd,' Bulletin van het Rijksmuseum, 36 (1988), 83-110.

15 See also for this section Wim François, 'Typology - Back with a Vengeance! Text, Images, and Marginal Glosses in Vorsterman's 1534 Dutch Bible,' in Imago Exegetica: Visual Images as Exegetical Instruments, 1400-1700, eds Walter S. Melion, James Clifton, and Michel Weemaes (Leiden: Brill, 2014), 89-136, esp. 108ff. Cf. Walter S. Melion, 'Bible Illustration in the Sixteenth-Century Low Countries,' in Scripture for the Eyes: Bible Illustration in Netherlandish Prints of the Sixteenth Century, exhib. cat., Museum of Biblical Art, New York City; Michael C. Carlos Museum, Emory University, Atlanta, eds James Clifton and Walter S. Melion (London and New York: Museum of Biblical Art and D. Giles Ltd, 2009), 14-106, esp. 15-26; Engammare, 'Les représentations de l'Écriture dans les Bibles illustrées du XVIe siècle,' 176-84.

16 Dit bosch bernende ende niet verbernende / is een figuere van de onbevleckte maechdoms des moeder Gods Maria.

17 See also François, 'Typology - Back with a Vengeance!', 120, with references to Biblia Pauperum, ed. Avril Henry (Ashgate: Aldershot, 1987), 51 and The Bible of the Poor [Biblia Pauperum]: A Facsimile and Edition of the British Library Blockbook C.9 d.2, eds Albert C. Labriola and John W. Smeltz (Pittsburgh, PA: Duquesne University Press, 2012), 16, 58, 100, 145-6. Also The Mirror of Salvation [Speculum Humanae Salvationis]: An Edition of British Library Blockbook G. 11784, eds. Albert C. Labriola and John W. Smeltz (Cambridge: Clarke, 2002), 30, 103-4; A Medieval Mirror: Speculum Humanae Salvationis 1324-1500, eds Adrian Wilson and Joyce Lancaster Wilson (Berkeley, CA: University of California Press, 1984), 154; Enriqueta Harris, 'Mary in the Burning Bush: Nicolas Froment's Triptych at Aix-en-Provence,' Journal of the Warburg Institute, 1 (1937-8), 281-6 (esp. 281 for the quotation).

18 Die tafel van der voorsettincs des broots figuere van tsacrament des outaers.

19 See also François, 'Typology - Back with a Vengeance!', 122-4. See there for further references.

20 Edwards, Printing, Propaganda and Martin Luther, 123-7. Cf. Flood, 'Martin Luther's Bible Translation,' 54-9. One of the basic works remains Peter Martin, Martin Luther und die Bilder zur Apokalypse: Die Ikonographie der Illustrationen zur Offenbarung des Johannes in der Lutherbibel 1522 bis 1546 (Hamburg: Friedrich Wittig Verlag, 1983). Cf. Engammare, 'Les représentations de l'Écriture dans les Bibles illustrées du XVIe siècle,' 166-8.

21 Bart A. Rosier, The Bible in Print: Netherlandish Bible Illustration in the Sixteenth Century, trans. Chris F. Weterings, vol. 1 (Leiden: Foleor, 1997), 13-14, and esp. 51-8, 119-21. It is uncertain who used the woodblocks first, although Rosier seemed still convinced that it was Fuchs; Nelly de Hommel-Steenbakkers, 'Censorship or Self-Protection? Modifications in Apocalypse Illustrations in Sixteenth-Century Bibles Printed in the Low Countries,' in Infant Milk or Hardy Nourishment? The Bible for Lay People and Theologians in the Early Modern Period, eds Wim François and August den Hollander (Leuven: Peeters, 2009), 191-221, esp. 193-5.

22 Rosier, The Bible in Print, vol. 1, 54-5 and 21; De Hommel-Steenbakkers, 'Censorship or Self-Protection? Modifications in Apocalypse Illustrations,' 195-7.

23 See, for example, the horrified monk seeking protection at Babylon's burning (18th image to the Apocalypse) and the devil as a bearded monk in the Gospel story of the temptations in the desert (cf. Cebus Cornelis de Bruin, De Statenbijbel en zijn voorgangers: Nederlandse bijbelvertalingen vanaf de Reformatie tot 1637, rev. Frits G. M. Broeyer [Haarlem: Nederlands Bijbelgenootschap and Brussels: Belgisch Bijbelgenootschap, 1993], 168-9). 
24 See the discussion of 'Moses Explaining the Rights of Priests' and 'Josiah has the Book of Law Read' in Rosier, The Bible in Print, vol. 1, 118-19.

25 Rosier, The Bible in Print, vol. 1, 121. Cf. Engammare, 'Les représentations de l'Écriture dans les Bibles illustrées du XVIe siècle,' 184.

26 Cf. James Kearney, The Incarnate Text: Imagining the Book in Reformation England (Philadelphia, PA: University of Philadelphia Press, 2009), 22: 'Protestants would reject the written word as an image.' The Amsterdam scholar August den Hollander has, however, asked the question as to whether the dramatic diminution of images in Dutch Protestant Bibles should only be ascribed to the (alleged) Protestant hostility towards pictures and images, or whether this phenomenon has also to do with the move of the production to the North of the Low Countries, where the tradition of including images in books was less developed than in the South (Antwerp).

27 Cf. the tripartite division of manuscript marginalia, marks of active reading (such as underlinings), marks of ownership (for example signatures or shelf marks), and marks of recording (debts, marriages, births, accounts, and so on), in Brayman Hackel, Reading Material in Early Modern England, 138.

28 Cf. Sherman, Used Books, 76.

29 Cf. Sherman, Used Books, 79, also 83.

30 Inviolata, intacta et casta es Maria.

31 Brayman Hackel, Reading Material in Early Modern England, 100.

32 The text contained in the added manuscript pages is not taken from the Old Testament in the Dutch 'Louvain Bible' of 1548, but from its predecessor, the Vorsterman Bible. It looks as if the text of the complete Louvain Bible was not available when the manuscript pages were written. Indeed, a New Testament edition containing the text of the Louvain Bible had already been published a few weeks or even months before the complete edition was brought onto the market in September 1548. Obviously, the manuscript had been written immediately after the publication of the New Testament, in order to fill the lack in the liturgical lessons of the same, after which it was bound together with the printed work. On the book binding, see Luc Indestege, 'Das Bild Karls V. auf flämischen Einbänden des XVI. Jahrhunderts,' Gutenberg Jahrbuch [36] (1961), 309-18, esp. 311.

33 Dat geheel nieuwe Testament ..., trans. Nicholas van Winghe (Leuven: Bartholomeus van Grave, 1548) (signature Leuven, Maurits Sabbe Library, P 225.055.1 BIBL 1548).

34 See the description and commentary by Marcel Gielis on the following websites: http:// lyrawww.uvt.nl/ mgielis/geloof\%20in\%20beeld/Bloemaert\%20Intercessie.htm; https://adel bertdenaux.wordpress.com/2012/12/04/de-mariologie-van-adelbert-denaux-in-beeld/ (accessed 25 October 2015).

35 Brayman Hackel, Reading Material in Early Modern England, 196: 'Many early moderns read their books to pieces.'

36 In this regard ground-breaking research has been done by Mart van Duijn on the remaining copies of the 'Delft Bible,' the very first printed Bible in Dutch (1477): Mart van Duijn, 'Gods Woord gemeengoed: Een sociale geschiedenis van de Delftse Bijbel (1477-ca.1550)' (PhD dissertation, Rijksuniversiteit Groningen, 2014). 


\title{
10 Diagnostic Performance and Diagrammatic Manipulation in the Physician's Folding Almanacs
}

\author{
Karen Eileen Overbey and Jennifer Borland
}

Bodleian MS Ashmole 6 (Figure 10.1) is one of around 30 known physician's folding almanacs - small manuscripts of medical reference material in Latin, all (save one) made in England around the fifteenth century. ${ }^{1}$ The folding almanacs are compact, most ranging from five to ten folios, with each folio devoted to a single element used for diagnosis or prescription: calendars, astrological tables, and medical canons. These manuscripts probably served many of the same diagnostic functions as other late medieval medical books, though with abbreviated contents - their calendars, tables, and diagrams were used to determine the appropriate timing of treatments,

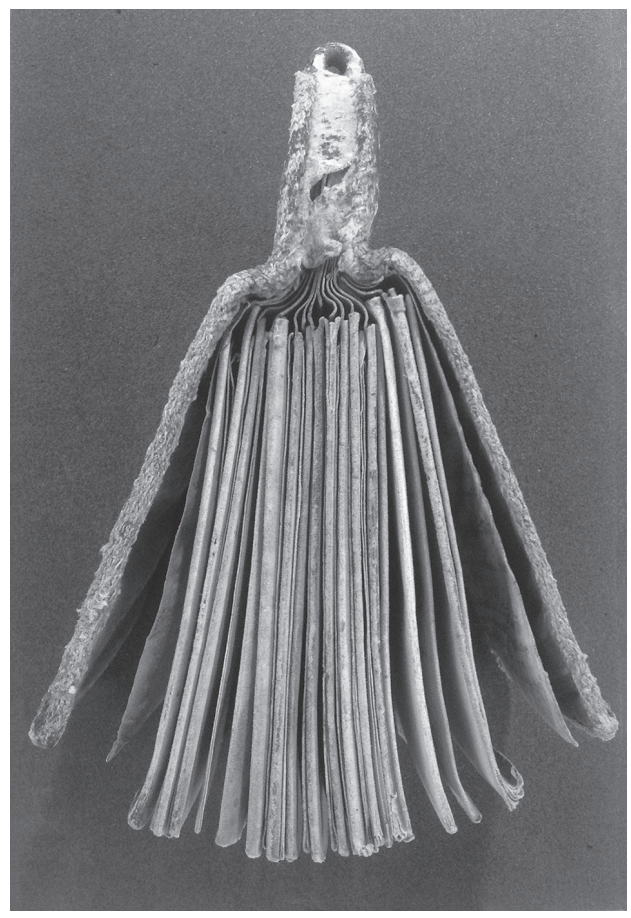

Figure 10.1 Folding Physician's Almanac, showing structure of folded folios with leather cover, overall length $15 \mathrm{~cm}$ England, fifteenth century. Oxford, Bodleian Library, MS Ashmole 6. 
including the administration of medicine as well as purging, bleeding, and cautery. ${ }^{2}$ What distinguishes the folding almanacs is their form: rather than a codex with quires sewn into a binding, each folio of the almanac is folded in half, and then again in thirds or sometimes fourths. Each sheet of parchment has a small, extended tab along one edge; when the folded sheets are stacked together, the tabs are gathered and stitched, often into a fabric or leather cover. With the folios folded this way, almanacs are also small in size: they are long and narrow, with folded dimensions averaging around $13 \times 5$ centimeters. This format, and the unusual binding, made the almanacs extremely portable. Some, such as Lambeth Palace MS 873, have been preserved along with leather cases, which may have protected them inside a purse ${ }^{3}$ others, such as Ashmole MS 6, still have their strong leather covers and a thick tab with an attached loop, to hang directly from its owner's belt. ${ }^{4}$ To use the information in the almanacs, a practitioner would detach the manuscript, turn to the relevant section, partially or fully unfold, refold, and unfold again. Rather than simply read as a diagnostic tool, the almanac requires manual handling: the images, charts, and texts were neither fixed nor held still in the hand, and in the process of treatment the almanac moved in the space between doctor and patient. Folding almanacs should thus be seen as part of a complex network in which patient, doctor, and book are all active, and in which the materiality of the almanac is instrumental.

As historians of science have shown, the content of the folding almanacs is critical to understanding the practices of late medieval medicine, in particular the role of astrology in diagnosis and treatment. ${ }^{5}$ The almanacs have also been briefly studied in art historical scholarship, primarily in terms of the iconography of Zodiac Man. ${ }^{6}$ But our concern is different: to understand the efficacy of the almanacs as located not only in their medical texts, their representational rhetoric, and their diagnostic functions, but also in their materiality. Almanacs were not simply a collection of useful texts: they were worn on the body, touched habitually, and manipulated like astrolabes and other scientific instruments, and this aspect of the almanacs has so far had little investigation. Our project considers the multiple social discourses in which almanacs were implicated: not only the prestige and practice of medieval medicine, but also issues of affect, shared space, bodily contact, wonder, secrecy, revelation, and memory. Our attention is on the 'objectness' of almanacs, the networks in which they acted, and their potency within the spaces of treatment.

Unfortunately, there is no direct textual or visual evidence for how doctors - or patients - used folding almanacs. ${ }^{7}$ Our proposals about the use and reception of the almanacs are based on careful examination of the manuscripts themselves, and on our own experiences manipulating them: holding, unfolding, turning, and opening. We draw on material evidence of wear and use, along with textual evidence of how itinerant doctors worked, to reconstruct the ways that almanacs were active in the encounter between doctor and patient. By closely examining the material aspects of almanacs - their structure, layout, and condition - we argue that this movement engaged both doctor and patient physically and affectively in the technology of treatment. This approach relies on both the intermateriality of almanacs (that is, their associations with other portable, personal objects imbued with efficacy, such as jewelry, amulets, and charms) and on their performative manipulation: gazing, fingering, opening, and closing. Folding almanacs, rather than simply a newfangled reference book, can be understood as a participatory space of knowledge in late medieval England. 


\section{Gestures of Diagnosis}

As Hilary Carey, Peter Murray Jones, and Faith Wallis have each argued, almanacs were most likely taken out in the field by trained doctors whose practices were not in court or urban settings, but rather around busy towns such as Norwich, Durham, and York. ${ }^{8}$ Whereas London doctors might be regularly employed in gentry households, provincial practitioners like Thomas Fayreford and John Crophill treated a range of patients in the town center and also in outlying areas: merchants, titled landholders, laborers; men, women, children. ${ }^{9}$ Not all doctors of this sort were university-trained physicians; Crophill, for example, was primarily employed as a bailiff of Wix priory, and was also a part-time ale taster. ${ }^{10}$ More often they had some professional training and a lot of practical, empirical knowledge about remedies and prognosis; most probably had a fair to good grasp of Latin, enough to comfortably use the almanacs' charts and tables, alongside a general familiarity with lunar astrology. ${ }^{11}$ The small size, portable format, and abbreviated texts of the folding almanacs provided the basic reference material for diagnosis of common complaints, and would have served the needs of itinerant doctors who were neither treating complex medical conditions nor performing surgery. Along with headaches and fevers, the ailment most often treated by Fayreford, for example, was 'suffocation of the womb': shortness of breath, anxiety, and seizures attributed to the swelling of the uterus. ${ }^{12}$

Medical care began with an understanding of timing - the time of day, season of the year, or part of the lunar cycle at which a patient fell ill - and so the calendar is the most basic component of all folding almanacs. ${ }^{13}$ It includes both liturgical feasts and detailed astrological information, and is typically arranged over three or four folios. The calendar was used in conjunction with charts of solar and lunar eclipses (Figure 10.2) to determine in which sign of the zodiac the sun or moon resided for any day of the month; it was also used with the table of planets, to calculate their locations throughout the day and assess their influence on the human body. ${ }^{14}$ This information was further coordinated with the Zodiac Man, which showed at a glance which stars ruled over which limbs, organs, and bodily fluids. Equipped with the proper astrological context for patient, location, and complaint, the practitioner could move on to diagnosis.

Most of the almanacs also include the most common diagnostic tool, uroscopy, as a canon text or in some of the more richly decorated examples as a vividly colored wheel of urine flasks. Patients brought their urine to the doctor, who compared it to the descriptions or images: red urine with mucus, for example, was a sign of an overheated liver. Following diagnosis, the doctor prescribed treatment, which could include medicines, herbs, charms, and bloodletting to balance the bodily humors. Nearly all the folding almanacs include texts on bloodletting, and often a diagram of Vein Man, showing the places on the body to tap for various conditions. Some of these prescriptions might be carried out by the diagnosing doctor, especially in more remote areas, but in larger towns a specialized apothecary mixed the medicines, and bloodletting was performed by a barber-surgeon. ${ }^{15}$

The diagnostic operations with the folding almanacs required a series of hand and even body movements, some sequential, some repeated: first, the almanac would be removed from the purse or case, or detached from the belt. Folded folios were thumbed or fanned or rifled until the proper calendar page was located. Then began a series of openings, turnings, and unfoldings. There is no fixed or standard arrangement of the pages of almanacs: calendars could be organized over three 


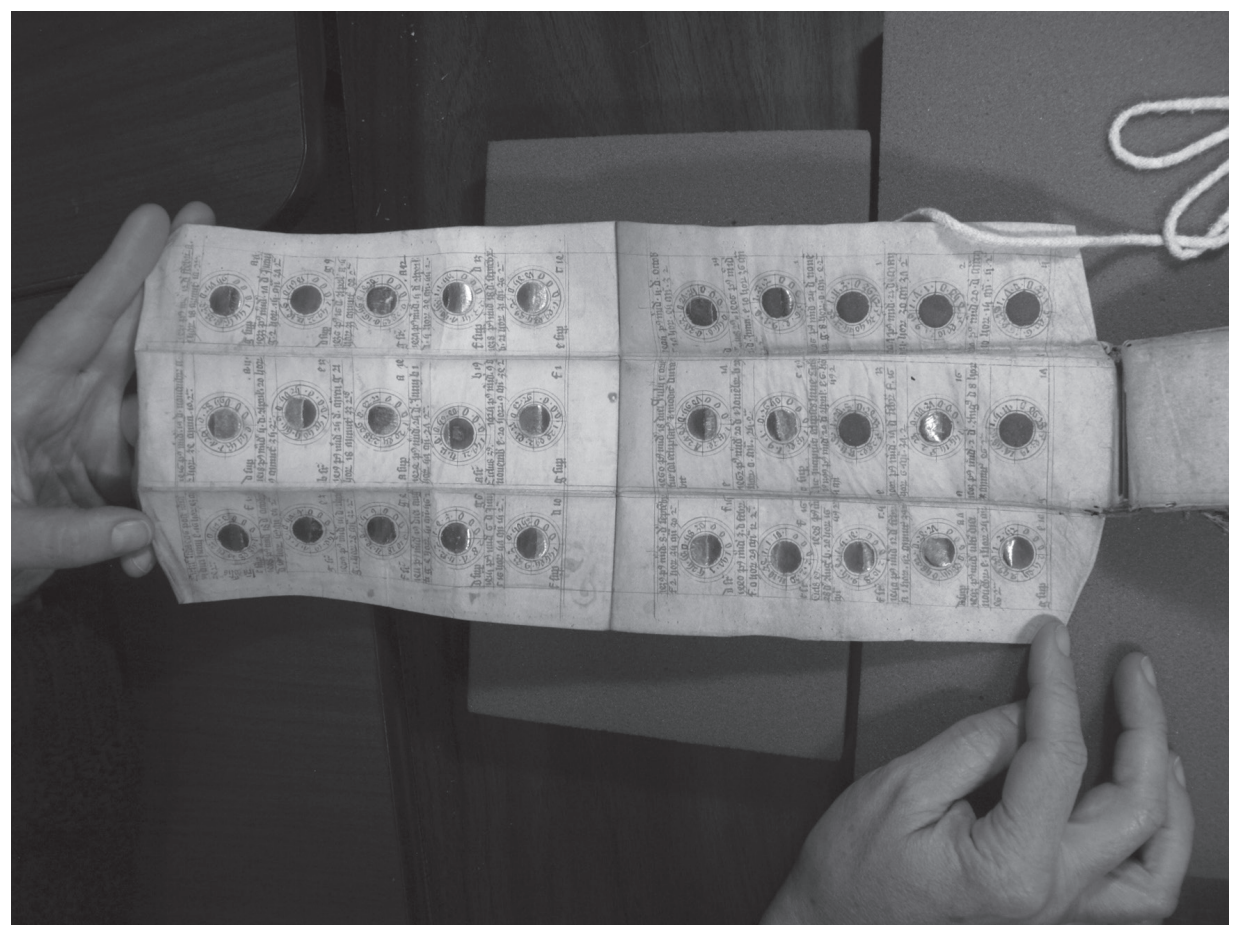

Figure 10.2 Charts of solar and lunar eclipses Almanach, tabula festorum, mobilium ab anno 1364 usque annum domini 1462, York, England, between 1406 and 1424. Philadelphia, The Rosenbach, MS 1004/29, fol. 7.

folios or four; canon texts on bloodletting and planetary influences sometimes cover a full folio and sometimes are abbreviated to a single column of text; some almanacs have interpolated material, such as illuminated lunar eclipse charts or elaborate tables of moveable liturgical feasts. These eccentric layouts meant that the gestures of diagnostic performance were personal gestures, unique to each doctor as he consulted his well-worn almanac.

To identify the proper astrological context for a patient's particular complaint, for example, the practitioner might first consult a calendar page: he would flip the almanac to the correct month, unfold the page, scan the text for the appropriate date, and close the page along the familiar creases. Next he might consult the lunar eclipse chart, with a similar series of unfoldings, openings, skimmings, and refoldings, and perhaps also again for the planetary tables. Most likely only one folio was opened at a time - the manuscript otherwise becomes cumbersome and difficult to hold - and so the manipulations could have become rather elaborate. (We found, for example, that it was not possible to hold a folio in just one spot to open it fully: it was necessary to take hold of a corner, lift up, change position with both hands, grasp again, and open.) Physicians who used the almanacs must have become deft at locating information and working the pages.

For the doctor, the gestures of unfolding would no doubt have become habit after a while, especially once the parchment had softened, become worn and pliable. Many of 


\section{8}

The Physician's Folding Almanacs

the manuscripts are stained along edges and at corners, from use and accident; many exhibit small tears where they have been folded over and over. Over time, the almanac, rather than needing to be fully read for each diagnostic encounter, could have become (to borrow a phrase from Mary Carruthers) a 'retrieval structure': a mnemonic device for choosing and recombining stored information. ${ }^{16}$ Individual visual features would also have served mnemonic functions. Most of the calendars and texts are highly abbreviated, and the outermost fold of each folio is a title page - blank, except for the names of the months or of the contents (octobri nouembri decembri in Morgan MS G.47, fol. 3, for example, or eclipses lunae in Rosenbach MS 1004/29, fol. 7). These title pages were certainly indexical; they could have functioned in the way of a decorated initial, as a trigger for reading and organization. Similarly, as for other medieval manuscripts, the distinguishing colors of red and black in the calendars, and the diaper patterns and grids of the planetary hours and lunar-zodiacal correspondences (as in Bodl. Rawl D928, Figure 10.3), are at once engaging visualizations and practical configurations of knowledge for easy retrieval, especially in the practiced movements of unfolding diagnosis. In some cases, simply manipulating the folded pages might have been enough to activate the physician's stored memory of data and diagnosis, in a gesture not unlike the fingering of rosary beads - another personal, tactile memory device, hung from the belt to be both displayed and handled.

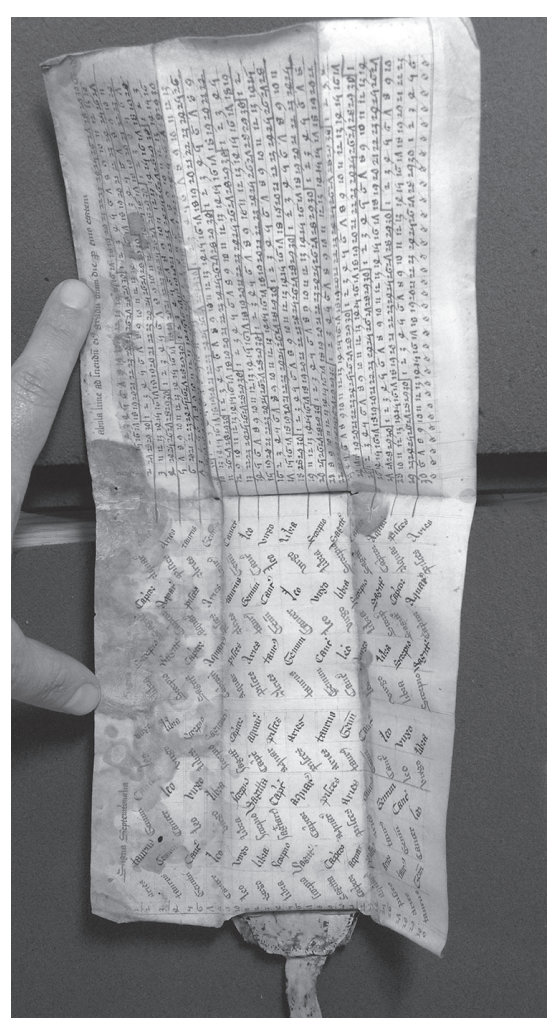

Figure 10.3 Table of planetary hours. Oxford, Bodleian Library, MS Rawlinson D928. 


\section{An Affective Network}

This familiarity on the part of the doctor would have made the performance of diagnosis quite a spectacle - the images, charts, and texts were not held still in the hand, but rather opened out, turned around, over, and sideways, moving quickly in the space between doctor and patient - a space which we assume to be fairly intimate, close enough to take the pulse and inspect a urine sample. ${ }^{17}$ There are no images of these encounters, but we can imagine physician and patient standing near to each other, perhaps with the almanac opened (or opening between them). ${ }^{18}$ For diagnostic uroscopy, for example, the urine flask must have been, at some point, held close to the color wheel - probably in the hands of the patient, while the doctor compared the color to that in the manuscript; holding both at once would be difficult. ${ }^{19}$ Prescription, too, could have involved some sharing of the almanac's contents: if bloodletting, for example, was to be performed by a surgeon other than the consulting physician, the patient might be shown the illustration of Vein Man and advised just where on the body the blood would be let.

There are wonderful rhythms to the mathematics and geometries of the pages, and for the patient, the practiced, manual operations could make the almanac magical, ritualized, and talismanic - particularly if the patient was not Latin-literate, or when the folding and unfolding was rapid, and the images flashed by quickly. While the folding almanac may have been a novel medical technology in late medieval England, it would have been familiar in its performativity and affectivity, as medieval medical practice combined academic instruction in medical theory and in the science of astrology with hands-on training in herbs, charms, and talismans. Doctors could recommend prayer or a visit to a saint's shrine along with apothecary medicines; gemstones with healing powers and charms written on pieces of parchment were not only in common use, but even recommended by medical practitioners alongside other, more scientific treatments. ${ }^{20}$ It was not only doctors who understood these relationships: healers and housewives made use of herbal remedies, prayers, and charms, and both folk medicine and saints' cults employed what we might call sympathetic magic, such as laying gemstones with healing attributes on afflicted parts of the body, or wearing talismanic jewelry. The late-fifteenth-century gold engraved Coventry Ring (British Museum AF.897), for example, displays the risen Christ and the five wounds on the outside, and has inscribed on the inside: 'The five wounds of God are my medicine, the holy cross and passion of Christ are my medicine, Caspar Melchior Baltazar ananyzapta tetragrammaton.' Ananyzapta and Tetragrammaton are relatively common magical 'nonsense' words in late medieval inscriptions, and the names of the three Magi were regularly invoked in healing rituals. When the ring was worn on the finger, the prayer was in direct contact with the skin, and could be rubbed or touched constantly, amplifying the potency of the medical invocation. Such jewelry, which was visible to others while it was simultaneously handled by the wearer, contributed to perceptions about the owner's access to knowledge and healing potential; folded almanacs likely conjured similar associations.

Rather than separate categories of treatment, these were all part of the repertoire of medieval doctors. The Rosa Medicinae, for example, a fourteenth-century medical treatise written by the Oxford-trained court physician John Gaddesden, contains a wealth of amuletic and ritual therapies, including gestures, drawings, herbal recipes, and verbal charms, such as a Latin incantation to cure nosebleed. ${ }^{21}$ Relatively few of 


\section{0}

The Physician's Folding Almanacs

these ephemeral products of health treatment survive; one that does, however, is a piece of parchment (Figure 10.4) that includes prayers and an image of St Margaret. Presumably so that it could be used repeatedly, this scrap was stored in a cylindrical leather-covered wooden box with incised and painted images of St Margaret, John the Baptist, and the Apostle Peter. The presence of St Margaret is in line with many of the textual references to such charms, due to her role as patron saint of childbirth and motherhood. ${ }^{22}$ That this image of Margaret has been vigorously rubbed attests to the extra potency its tangibility offered; it must have been touched, over and over, by many patients seeking cures. Healing remedies like this worked through a combination of tactility, gesture, and manipulation that could have provided a context for the movements of the almanac. Doctor, patient, and parchment are all implicated in the exchange - what Jane Bennett calls a 'temporary working assemblage,' a locus of 'affection and allure. ${ }^{23}$

\section{Performing the Space of Knowledge}

During the doctor's operations with the folding almanacs, the patient would have seen the reverse of whatever folio the physician opened: text, images, or charts often upside down, or sideways. (In the Morgan almanac, for example, when the doctor held up the

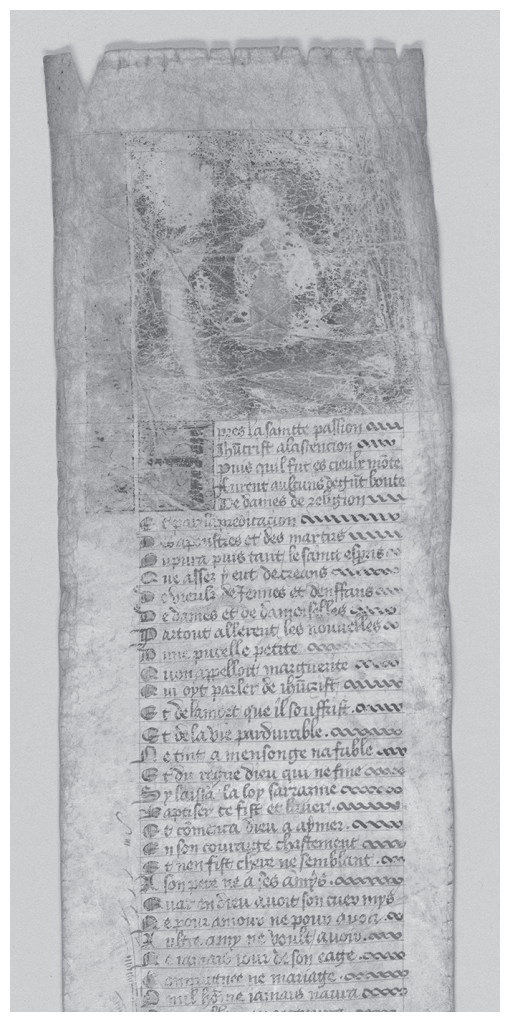

Figure 10.4 St Margaret emerging from the Dragon. Vie de Sainte Marguerite. France, probably Paris, 1491. New York, The Pierpont Morgan Library, MS M.1092, Recto. 
diagram of Vein Man and the texts on bloodletting, the image of Zodiac Man would have faced the patient, with the top of the head at the bottom of the page.) Some of these must have been familiar - a landholder with a good income, for example, may have owned a Book of Hours with a calendar, and had enough practical literacy to make out some of the headers. ${ }^{24}$ Even a patient without textual literacy, however, could have recognized the images of Zodiac Man and Vein Man; with their contemporary hair styles, even inverted, they must have at least been recognizable as bodies, relatable to his or her own body. ${ }^{25}$ Patients (who had certainly come to the encounter with the expectation of being diagnosed and treated, if not eventually cured) might therefore have eagerly received the seemingly magical manipulations of the almanac as a kind of gestural charm, and even taken the glimpses of planetary tables to be a fortune-telling game or divination chart - information visualizations that they might have recognized, other popular kinds of prognostication, and ones which also had cosmic significance.

This kind of correspondence is exactly the point: that is, correspondence itself is central to the efficacy of the almanacs, and indeed of all medieval medicine, which lay out the correlation of macrocosm and microcosm, and assessed the effects of stars, planets, and elements on the body and mind. Diagnosis depended on a multivalent understanding of the relations between the human body and heavenly bodies. As Luke Demaitre puts it, 'everything, including the human body, was connected in the vastness of the universe and in the cycle of life,' and so understanding celestial influences was key in preventative medicine, useful for diagnosis of chronic conditions, and even employed for acute complaints like headaches and broken bones. ${ }^{26}$ The content of the folding almanacs, like other medical manuscripts in codex form, is primarily made for figuring out these microcosmic correspondences.

But the almanac - in contrast to other medieval medical sources - was more than just a reference for these concordances. It moved in the space between doctor and patient, opening, turning, coming close, pulling away - creating an active and activated space of healing between the body of the doctor and the body of the patient. Physical manipulation of diagnostic tools was not unique to folding almanacs. Moving information wheels or volvelles are found in other late medieval medical and scientific manuscripts, including the well-known Guild Book of the Surgeons of York (BL Egerton 2572, fol. 51r), dating to the last quarter of the fifteenth century. The York volvelle was used, like the tables and calendars of the folding almanacs, to calculate the position of the sun and moon in the signs of the zodiac, and to determine whether a particular procedure was astrologically auspicious. In comparison to volvelles, the almanacs - with their complicatedly folded folios and multiple manual gestures - offer a much less economical, more unwieldy way to calculate information: a few turns of the disc wheels could accomplish the same readings as a whole series of foldings, unfoldings, scannings, and shufflings. But the requirements of the almanac implicate the body in the diagnostic process to a much greater degree than do the volvelles. This might be understood as a simple distinction between a bound codex and a folding book. But we want to suggest a more agential difference, and a difference in spatial expectation of the user. Through the operations of the almanac, both patient and doctor are engaged visually, physically, and perhaps even emotionally in the negotiation of image, space, and animation. Lynda Nead has argued that for early motion pictures, especially those in which things like speeding trains are depicted, there was a kind of 'synergy between the viewer and the image'; as a 'display of the spectacle 


\section{The Physician's Folding Almanacs}

of movement,' the films elicited 'highly motivated physical responses from their audiences, who themselves became part of the spectacle. ${ }^{27}$ Folding almanacs can perhaps be understood as a similar kind of participatory spectacle, one in which physician, patient, and parchment are all active. Affect and wonder, then, are not only part of the reception of almanacs, but integral to their very workings, and part of their efficacy.

Of course, all kinds of medieval images suggest movement and multidimensional perception, and implicate the body in the cognitive process. Perspective, for example, often required mental manipulation to effect spatial reorientation. As Linda Neagley has argued, the doors and windows of the Bayeux Embroidery lead to interior scenes which we should understand as turned perpendicular to the picture plane; these architectural representations fostered an embodied sense of space that allowed the viewer to 'envision himself as a witness to an event in real time and space. ${ }^{28}$ A similar process of imaginative manipulation leading to the beholder's spatial self-awareness operates in late medieval devotional wall painting, such as in the parish church at Stoke Dry, Rutland, which is roughly contemporary with the almanacs. In the image of the martyrdom of St Edmund (Figure 10.5) the archers are surely not meant to be piercing the saint directly from each side. The visitor to the chapel must imaginatively 'fold' the image into three dimensions so that the archers stand in front of Edmund and, in an

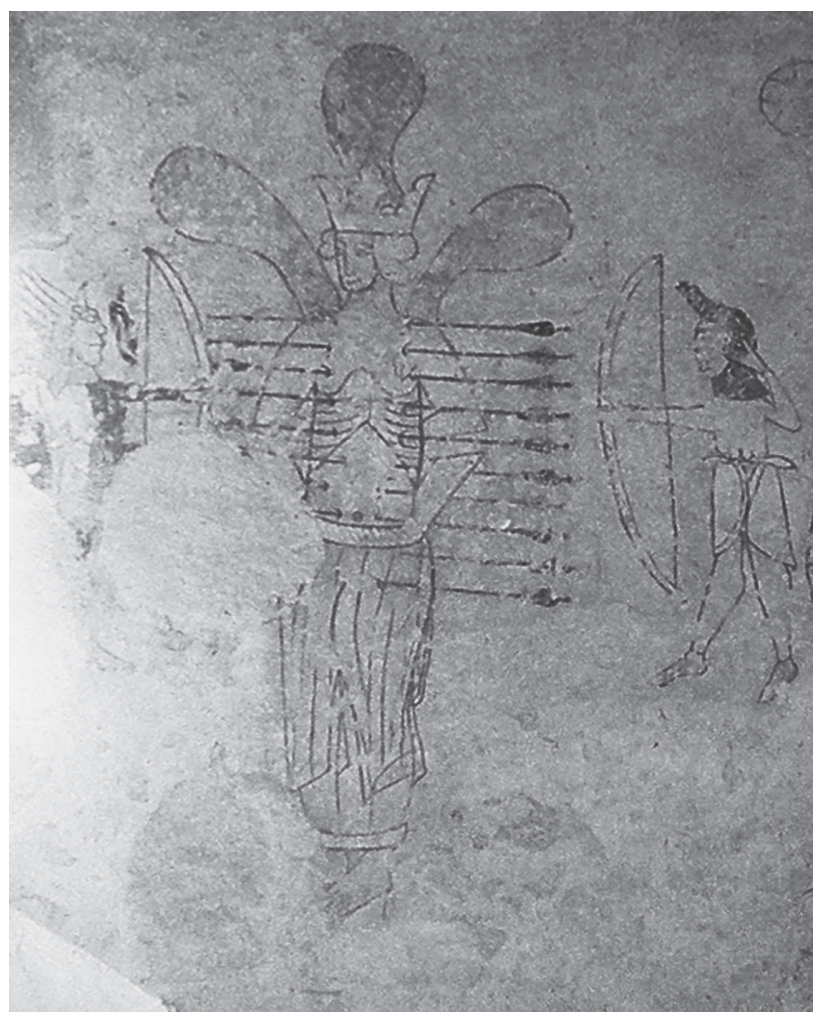

Figure 10.5 Martyrdom of St Edmund. Wall painting at St Andrew's Church, Stoke Dry, Rutland. 
anagogical collapse of time, also occupy the space of the medieval worshipper. This kind of visual and mental exercise - a sort of virtual reality machine, or 3D generator put viewers into active, constructive encounter with images and their meanings, and required (or even nurtured) an active, constructive subjectivity. ${ }^{29}$

The somatic experience of the almanacs, we propose, could incite the beholder to an analogous mental practice, in which the manipulation of image and memory encouraged consideration not of historical or teleological position, but of cosmic position: the relationship of human body to celestial bodies, of microcosm to macrocosm. This contemplation is grounded both in the medical content of the almanacs and in their intermateriality - their associations with a range of popular objects and images, from talismans to gambling games. Through that network of associations, both material and spatial, the manuscripts produced the space of treatment itself; the field of doctor, patient, and almanac can be understood as a space of macrocosmic connection, a node of knowledge. Within that field, the almanac functions as a moving diagram, an animated version of the complex mnemonic images based on Alain of Lille's De sex alis cherubim, or of the cosmic visualizations of Byrthferth of Ramsey's computational treatises. The twelfth-century illumination of the latter (in BL Harley MS 3667, fol. 8r), for example, superposes the Ages of Man, the cardinal directions, the bodily humors, the four winds, and the four gospels to demonstrate the unity of heaven and earth. In the almanacs, various aspects of cosmographic knowledge are collected - we might even think of them as layered together, when the almanac is folded closed and reconstituted around the bodies of patient and doctor. Thus the performance of diagnosis and cure is also a performance of the cosmically balanced body.

$* * *$

As with the St Margaret parchment and the paintings at Stoke Dry, the instrumentalization of the folding almanac requires active participant beholders, manipulating image and memory to locate themselves within space and time. The almanac becomes a space of knowledge, not only through its astro-medical content, but also (and, we argue, especially) through its constructive encounters with patient and doctor. While certainly the Latin texts and scientific information were central to specific medical learning, authority, and competence, the performative operations of the almanac should be seen as another 'instrument' of that science. Patient and doctor are located within the cosmographic system of celestial influences, bodily humors, and healing actions - all of these multiple and complementary modes of knowledge move in and through the space at the hands of the doctor.

\section{Acknowledgements}

Our research on this project was facilitated by access to materials at a number of libraries and collections, including the British Library, London; the Bodleian Libraries, Oxford; Lambeth Palace Library, London; the Morgan Library and Museum, New York; the National Library of Scotland, Edinburgh; the Rosenbach Museum and Library, Philadelphia; the Library, Royal Observatory, Edinburgh; and the Wellcome Collection, London. We are particularly grateful for the assistance of Karen Moran at the ROE, Elizabeth Fuller at the Rosenbach, and Amanda Engineer and Stefania Signorello at the Wellcome. Jack Harnell and Adrienne Albright each shared their own related work with us and provided helpful feedback on this project, as did Emily 
Gephart and our colleagues in the Material Collective. Anna Klosowska pointed out intriguing correspondences between some almanac material and fortune-telling games, and Krystl Hall helped us realize the spatial possibilities of the almanacs. Our sincere thanks to these colleagues for their generosity and collaboration. An earlier version of this project was presented at 'Medieval Art History After the Interdisciplinary Turn,' University of Notre Dame, March 2014. We thank the organizers and participants, especially Beate Fricke, Cecily Hilsdale, Danielle Joyner, Alicia Walker, and Aden Kumler for their comments and support.

\section{Notes}

131 English folding almanacs are currently known. For terminology, general description, discussion of the debates surrounding function, and a list of known English almanacs as of 2003, see Hilary M. Carey, 'What is a Folded Almanac? The Form and Function of a Key Manuscript Source for Astro-medical Practice in Later Medieval England,' Social History of Medicine, 16 (3) (2003): 481-509; see also Hilary M. Carey, 'Astrological Medicine and the Medieval English Folded Almanac,' Social History of Medicine, 17 (3) (2004): 345-363. Carey dates the almanacs on the basis of calendar information; the earliest is Oxford, Bod. Lib. Rawl. D 938 (1348) and the latest Ballarat, Victoria, Fine Art Gallery Crouch 4 (1508). In the most recent study, J. P. Gumbert lists 30 English almanacs from among 63 books in total using this format; Gumbert, Bat Books: A Catalogue of Folded Manuscripts Containing Almanacs or Other Texts (Turnhout: Brepols, 2016). Gumbert leaves out National Library of Scotland MS Acc.12059.3. We thank Jessica Legacy for her observations in this regard.

2 Carey, 'Astrological Medicine,' 350. They have also been compared to other folded and/or portable manuscripts, such as folded calendars and folded books, although in England the folded format was used almost exclusively for medical almanacs; see Carey, 'What Is the Folded Almanac?' 486ff, 488. An example of a non-medical folding almanac is London, BL Egerton 2724; BL Egerton 828 is a medical manuscript with similar content (including a zodiac man) but in codex form.

3 Some images of physicians with purses, which have usually been assumed to be for money, may be for portable reference books like the folding almanacs; see for example C. H. Talbot, 'A Medieval Physician's vade mecum,' Journal of the History of Medicine and Allied Sciences 16 (1961): 213-33, at 213-14.

4 Carey, 'Astrological Medicine,' 358.

5 Carey, in both 'What Is the Folded Almanac?' and 'Astrological Medicine,' gives a thorough review of the scholarship. See also Cornelius O'Boyle, 'Astrology and Medicine in Later Medieval England: The Calendars of John Somer and Nicholas of Lynn,' Sudhoff's Archiv, Bd. 89, H. 1 (2005): 1-22.

6 This work includes Peter Murray Jones, Medieval Medical Miniatures (Austin, TX: University of Texas Press, in cooperation with the British Library, 1985), revised as Medieval Medicine in Illuminated Manuscripts (London and Milan: Centro Tibaldi, 1998); Peter Murray Jones, 'Image, Word, and Medicine in the Middle Ages,' in Visualizing Medieval Medicine and Natural History, 1200-1550, eds Jean A. Givens, Karen M. Reeds, and Alain Touwaide (Aldershot, UK and Burlington, VT: Ashgate, 2006): 1-24; Sara Öberg Strådal, 'Medieval Medical Diagrams: meanings, audiences, and functions,' Hektoen International, 5 (3) (2013) http://www.hektoeninternational.org/ (accessed 5 November 2015); K. B. Roberts and J. D. W. Tomlinson, The Fabric of the Body: European Traditions of Anatomical Illustrations (Oxford: Clarendon Press, 1992).

7 In several satirical bas-de-page scenes of a copy of the Decretals of Gregory IX (BL Royal 10 E IV, fols 53v and 54), Reynard the Fox appears dressed as a physician who pretends to treat his enemy Isegrim the wolf; Reynard wears a belt with suspended pouches; other examples of a physician with books or pouches hanging from a belt include Copenhagen, Kongelige Bibliotek, MS GKS 227 2o, fol. 28r, and Heidelberg Cod. Pal. germ. 644, 94v. While these images are suggestive of how folding almanacs were likely carried, none can be definitively identified as representations of their use. Talbot discusses the practice of wearing books in 
pouches, suggesting this is how some almanacs were worn and noting that this is similar to how clerics carried small breviaries: Talbot, 'A Medieval Physician's vade mecum,' 213-33, at 214. For small books carried on belts, see Emily Diane Pietrowski, 'Multum in parvo: The Miniature Hours of Edith G. Rosenwald as Woman's Devotional Book and Amulet,' Master's Thesis, University of Texas at Austin, 2013. Carey, 'What is the Folded Almanac?' also considers how they were worn. For additional suggestions regarding use and wear, see Gumbert, Bat Books, 19-24. For more on the satire of physicians, see Linda Ehrsam Voigts, 'FifteenthCentury English Banns Advertising the Services of an Itinerant Doctor', in Between Text and Patient: The Medical Enterprise in Medieval and Early Modern Europe, eds Florence Eliza Glaze and Brian K. Nance (Florence: SISMEL, 2011): 245-77. Good accounts of practice and training include Faith Wallis (ed.), Medieval Medicine: A Reader (Toronto: University of Toronto Press, 2010): 195-204; Nancy Siraisi, Medieval and Early Renaissance Medicine: An Introduction to Knowledges and Practice (Chicago: University of Chicago Press, 2009); Carol Rawcliffe, Medicine and Society in Later Medieval England (Stroud, Gloustershire: Sutton, 1995): 58-81; and Katherine Park, 'Medical Practice,' Cambridge History of Science, Volume 2: Medieval Science, eds Michael H. Shank and David C. Lindberg (Cambridge: Cambridge University, 2013): 611-29.

8 Harry Bober suggests that folding almanacs 'accompanied the doctor on his calls' while the codex form of medical calendars were intended for 'home use'; see 'The Zodiacal Miniature of the Très Riches Heures of the Duke of Berry: Its Sources and Meaning,' Journal of the Warburg and Courtauld Institutes, 11 (1948): 1-34, at 24.There is a debate regarding who used the almanacs; Carey, 'Astrological Medicine,' 355-60 argues for a range of users, including physicians but also people generally interested in astrology. See also Peter Murray Jones, 'Information and Science,' in Fifteenth-Century Attitudes: Perceptions of Society in Late Medieval England, ed. Rosemary Horrox (Cambridge: Cambridge University Press, 1994): 97-111, at 109; and Talbot, 'A Medieval Physician's vade mecum,' 218-19. Another possibility is that they were used by doctors, but that the exact medical information was less important than the appearance of learned medical authority conveyed by wearing the book. Until the mid-fifteenth century in England the profession was primarily made up of clerics; the almanacs coincide with the rise in non-clerical practitioners, the 'scramble for patronage,' the growth of vernacular medical texts, and an increasingly specialized medical hierarchy; see Rawcliffe, Medicine and Society, 105-26. The almanacs certainly gave prestige and authority to doctors, particularly to itinerant practitioners, at a time when 'licensing procedures and other institutional markers of competence' were a subject of public concern; see Park, 'Medical Practice,' 624.

9 Both Fayreford (fl.1400-50) and Crophill (d.1485) are known through their surviving manuscripts - not folding almanacs, but commonplace books that include medical treatises and records of patients treated: BL Harley 2558 (Fayreford, in Latin) and Harley 1735 (Crophill, in English). See Peter Murray Jones, 'Thomas Fayreford: An English Fifteenth Century Medical Practitioner,' in Medicine from the Black Death to the French Disease, ed. Roger French (Aldershot, UK and Burlington, VT: Ashgate, 1998): 156-83; E. W. Talbert, 'The Notebook of a Fifteenth-Century Practicing Physician,' Studies in English, 22 (1942): 5-30; and James K. Mustain, 'A Rural Medical Practitioner in Fifteenth-Century England,' Bulletin of the History of Medicine, 46 (1972): 469-76.

10 Mustain, 'A Rural Medical Practitioner,' 471; Voigts, 'Fifteenth-Century English Banns,' 259.

11 Most almanacs have basic rather than specialized astrological information, similar to what was available in popular, vernacular scientific literature. See Carey, 'What Is a Folded Almanac?' and 'Astrological Medicine.'

12 Jones, 'Thomas Fayreford,' 170-3. This ailment, discussed by Classical authors including Hippocrates and Galen, was most often treated by placing sweet-smelling substances near the vagina and foul-smelling substances near the nostrils.

13 Carey, 'Astrological Medicine,' 363.

14 The calculations possible with the almanac are not as specific as those made with astrolabes and other measuring devices (which could account more precisely for meridians and geographic locations) but presumably they were good enough for calculations in the field and would meet the basic computational needs of medical astrology. See Lynn White, Jr, 'Medical Astrologers and Late Medieval Technology,' Viator, 6 (1975): 295-308, and Wallis, Medieval 


\section{The Physician's Folding Almanacs}

Medicine, 317-34. On the use of almanacs for medical astrology, see Carey, 'Astrological Medicine,' and O'Boyle, 'Astrology and Medicine.' Astrological and calendrical tables were also essential for selecting propitious times for practices, including bleeding, purging, and medicating, as well as for picking herbs and preparing various talismans.

15 For discussions of types of medical practitioners (physician, barber, surgeon, apothecary, leech) and their various training and practices, see Vern L. Bullough, 'Medical Practice in the Middle Ages, or Who Treated Whom,' in Bullough, Universities, Medicine and Science in the Medieval West (Aldershot: Ashgate, 2004), 277-288; Carole Rawcliffe, 'The Profits of Practice: The Wealth and Status of Medical Men in Later Medieval England,' Social History of Medicine, 1 (1988): 61-78; and Rawcliffe, Medicine and Society, 105-215.

16 Mary Carruthers, 'Ars oblivionalis, ars inveniendi: The Cherub Figure and the Arts of Memory,' Gesta, 48 (2) (2009): 99-118, at 111.

17 Reynard (as physician) and Isegrim (as patient) are close to one another in the images from BL Royal 10 E IV (see above, note 7), and Bod. Lib. Ashmole 399 fol. 34v depicts patients holding their urine flasks as they wait to see the physician. For more on physician-patient interactions, see Michael R. McVaugh, 'Bedside Manners in the Middle Ages,' Bulletin of the History of Medicine, 71 (2) (1997): 201-223.

18 While a codex would likely have rested on a table, we found the almanac to be more awkward to handle if it is not held in the hands.

19 This speculation presumes that the colours in the uroscopy wheels were considered practical and diagnostic, and that chromatic accuracy was both desirable and possible; other interpretations of the uroscopy wheels are surely possible. We appreciate discussions of this problem with Carly B. Boxer, who generously shared some research in progress.

20 See Lea T. Olsan, 'Charms and Prayers in Medieval Medical Theory and Practice,' Social History of Medicine, 16 (3) (2003): 343-366 and Peter Murray Jones, 'Amulets: Prescriptions and Surviving Objects from Late Medieval England,' in Beyond Pilgrimage Souvenirs and Secular Badges, ed. Sarah Blick (Oxford: Oxbow, 2007): 92-107.

21 Tony Hunt, Popular Medicine in Thirteenth-Century England: Introduction and Texts (Woodbridge: D. S. Brewer, 1990), chapter 1, and Olsan, 'Charms and Prayers,' 344-55; both discuss Gaddesden. Many astro-medical texts from this period were accompanied by charms. See Rawcliffe, Medicine and Society, 94-5, 218; Linda Ehrsam Voights, 'What's the Word? Bilingualism in Late-Medieval England,' Speculum, 71 (4) (1996): 813-26; Lea T. Olsan, 'Marginality of Charms in Medieval England,' The Power of Words: Studies on Charms and Charming in Europe, eds James Kapalo, Eva Pocs, and William Ryan (Budapest: Central European University Press, 2013): 135-64; and Olsan, 'The Corpus of Charms in Middle English Leechcraft Remedy Books,' Charms, Charmers and Charming: International Research on Verbal Magic, ed. Jonathan Roper (Basingstoke: Palgrave Macmillan, 2009): 214-37.

22 Don C. Skemer, 'Amulet Rolls and Female Devotion in the Late Middle Ages,' Scriptorium, 55 (2001): 197-227.

23 Jane Bennett, 'Systems and Things: A Response to Graham Harman and Timothy Morton,' New Literary History, 43 (2) (2012): 225-33, at 231.

24 It has been estimated that around 40 percent of male householders in late medieval London had some knowledge of Latin; Stanford E. Lehmberg, A History of the Peoples of the British Isles, vol. 1 (London: Routledge, 2002): 137.

25 Stråland points out this detail in 'Medieval Medical Diagrams.'

26 Luke Demaitre, Medieval Medicine: The Art of Healing, From Head to Toe (Santa Barbara, CA: Praeger, 2013): 15.

27 Lynda Nead, 'Velocities of the Image c.1900,' Art History, 27 (5) (2004): 745-69, at 756.

28 Linda Elaine Neagley, 'Portals of the Bayeux Tapestry: Visual Experience, Spatial Representation, and Oral Performance,' in The Bayeux Tapestry: New Approaches, eds Michael J. Lewis, Gale R. Owen-Crocker, and Dan Terkla (Oxford: Oxbow Books, 2011): 136-46, at146.

29 On subjectivity and active reading of images, see Suzanne Lewis, Reading Images: Narrative Discourse and Reception in the Thirteenth-Century Apocalypse (Cambridge: Cambridge University Press, 1995) and Carruthers, 'Ars oblivionalis, ars inveniendi.' 


\title{
11 Surgical Saws and Cutting-Edge Agency
}

\author{
Jack Hartnell
}

Paracelsus, the totemic figure of Renaissance medicine, chemistry and natural philosophy, wrote of surgery in his Große Wundarznei (1536):

sonder es ist ein gewisse Kunst und ein warhafte, gleich so fertig als ein zimerman in seim zimern... kan es aber nit recht, so ratschlag er all tag und noch wird nichts guts daraus. felt am lezten alles ein.

it is a certain art and a true one, exactly as skilful as a carpenter in his carpentry ... if [the surgeon] cannot do it right, then he might ask advice all day and night, and nothing good will come of it. Everything will collapse in the end. ${ }^{1}$

Two professions give way into one. The surgeon is conflated with the woodworker, the body with the machine, and death with mechanical breakdown or fault. This was a common trope in writings on the surgical discipline in the later Middle Ages and early Renaissance. The thirteenth-century French surgeon Henri de Mondeville, for example, wrote of ways to cure what he dubbed 'that ingenious device' - the engine of the body - echoing physicians since Hippocrates and Galen who had long conceived of food as a form of semi-combustible fuel, providing heat and stoking the furnace of the body's mechanical operations. ${ }^{2}$ Man and machine were even brought together quite literally in the polymorphous fourteenth-century treatises on both medicine and engineering by the Italian inventor and anatomist Guido da Vigevano, as likely to contain plans for a crusader crank-wagon as a retro-orbital neuroanatomy. ${ }^{3}$

As Pamela Smith has eloquently shown, Paracelsus and his contemporaries were the harbingers of a gradual epistemic shift in relation to medicine and artisanship. ${ }^{4}$ Generations earlier, groups of artists and makers had used an intensified detailing of nature to refigure the act of imaging into a claim to knowledge itself, attempting to express an increasingly intellectual understanding of the natural philosophical world they so accurately depicted. Craftsmen of the fifteenth and sixteenth centuries a bracket that included surgeons - built on this conviction, narrating with competency and vivacity their interactions with both matter and the human form. But as well as a common intellectual ambition, surgeons and other artisans also shared much more literal ground too: their tools. Surgical writers encouraged the use of the blacksmith's pincer and tongs, the cooper's gimlet (used for piercing barrels), or the carpenter's gouge, normally designed to mark grooves in beams but reworked and extolled by some surgeons as the best device for searching out wounds in the head and trepanning the skull. ${ }^{5}$ 


\section{Surgical Saws and Cutting-Edge Agency}

Prime among these cross-pollenated tools were saws. Just as comfortable in the hand of carpenters working wood, butchers dividing flesh, foresters felling trees and surgeons operating on patients, these toothed blades were a vital part of many a craftsman's toolkit. They do not, however, respond well in the hands of the historian, littered as they are with a wide range of historicising complications. ${ }^{6}$ Matters of survival are paramount: we know of these quotidian objects through their presence in various tangential medieval sources - literary, visual, archaeological - yet very few of them actually survive today. And this paucity makes their structures of facture and use hard, if not impossible, to unravel. Of extant medieval and renaissance saws, few have firm evidence of specific makers, owners or patients upon whom they worked. Concerned primarily with fitting such objects into retrospective histories of today's surgical terminologies, historians have not tended to consider such artefacts creatively.

Here, I want to briefly explore several ways in which we might reverse this historical trend. Using as a springboard the saw's quotidian location between the realms of aesthetics and practicality, I want to think about these objects as witnesses to diverse medical and social practices, and in so doing present them anew as fierce historical agents. But importantly, I want to explore in their agency something more than Alfred Gell's broad anthropological 'magic' or Maurice Merleau-Ponty's conception of an object's phenomenological sentience. ${ }^{7}$ Rather than presenting their object agent-hood as a cure-all to their broad historical problems, I want to use the term as a structure for thinking through these tricksy things. For as this volume re-visits the Pandora's Box of 'agency', first opened some 20 years ago, it is important to keep in mind that its complex presence in objects like surgical saws might not in fact be a solution. It might instead be the very problem in the first place.

The evolution of limb amputation stretches back to prehistory, and on the whole it seems not to have been particularly successful. Most operations resulted in the patient's death, and despite a slow trajectory of improvement from the Classical world through to the Middle Ages, with further developments in surgical understanding prompted by refreshed anatomical exploration in the sixteenth century, amputations before the modern era were perilous, fraught with complication and often mortally wounding. 8

But although it was most often a failure in medical terms, amputation nevertheless triumphantly courted a broader cultural imagination, with authors of various types fixating upon the process and its metaphorical potential. Take the hagiographer of the doctor saints Cosmas and Damian, who inserted into their twelfth-century vita an episode in which a man prays that the pair heal his leg, riddled with cancer. ${ }^{9}$ Responding to his Christian call, Cosmas and Damian appear to him in a dream the following night bearing ointments and iron surgical instruments, whereupon they remove the limb, and rather than leave him one-legged - miraculously replace it with that of an Ethiopian man recently buried in a nearby churchyard (Figure 11.1). Radically and racially transformed, the man awakes the following morning fully healed of his ills. Few actual cases from the period are narrated with as much detail as this miraculous transplant, although one particularly vivid first-hand account survives describing the amputation of the particularly high-status leg of Holy Roman Emperor Friedrich III (Figure 11.2). ${ }^{10}$ Suffering from a gangrenous infection, thought at the time to be gout brought on by an over-consumption of melons, Friedrich's foot slowly turned numb and then green and then black. On 8 June 1493 in the city of Linz, the leg was removed by the Jewish surgeon Hans Seyff, who wrote a brief account of the operation now split between 


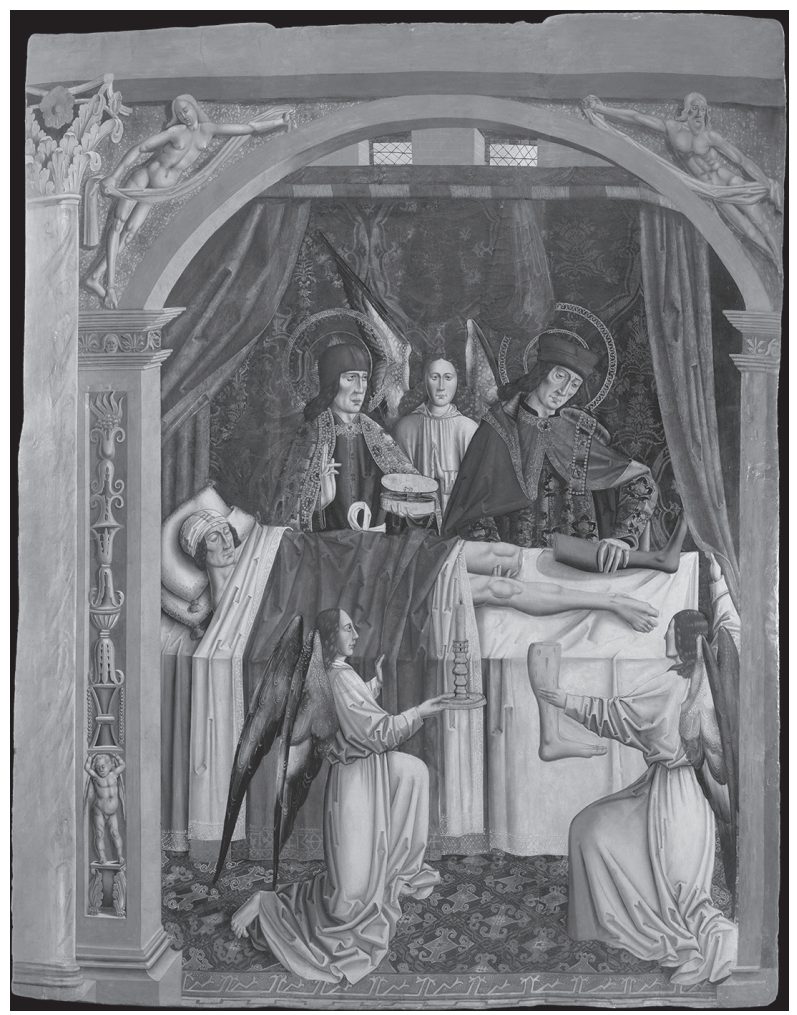

Figure 11.1 Attributed to the Master of Los Balbases, Saints Cosmas and Damian Performing the Miracle of the Transplanted Leg, oil on wooden board, c.1495. Wellcome Collection, London.

documents in Stuttgart and Vienna. Perhaps Seyff was compelled to put pen to paper by the immense pressure of the situation, operating in the presence of lords, knights and seven of the king's personal doctors, or perhaps the report was intended as insurance, an attempt to separate the operation (viewed as a success) from Friedrich's death by infection some weeks later (less successful). Whatever occasioned it, as an accurate surgical record it remains virtually unique. Accounts of amputations were far more likely to appear under fantastical or divine auspices, subsuming the oft-fated surgical procedure into a reassuringly familiar trope of sickness and miraculous cure.

The only surviving witnesses to these medieval and early-modern surgical procedures are the amputation saws themselves. Today scattered among museums from London to Leiden to La Paz, there are some consistencies in this rather widely constituted group. All are ether iron or steel, all sport a similar bow-shaped construction, and they are often of around the same ergonomic size, between 40 and $60 \mathrm{~cm}$ from handle to tip. Those which survive in approachable condition stem only from the very end of the Middle Ages and Early Renaissance, and a surprisingly large number of these are intricately decorated. 


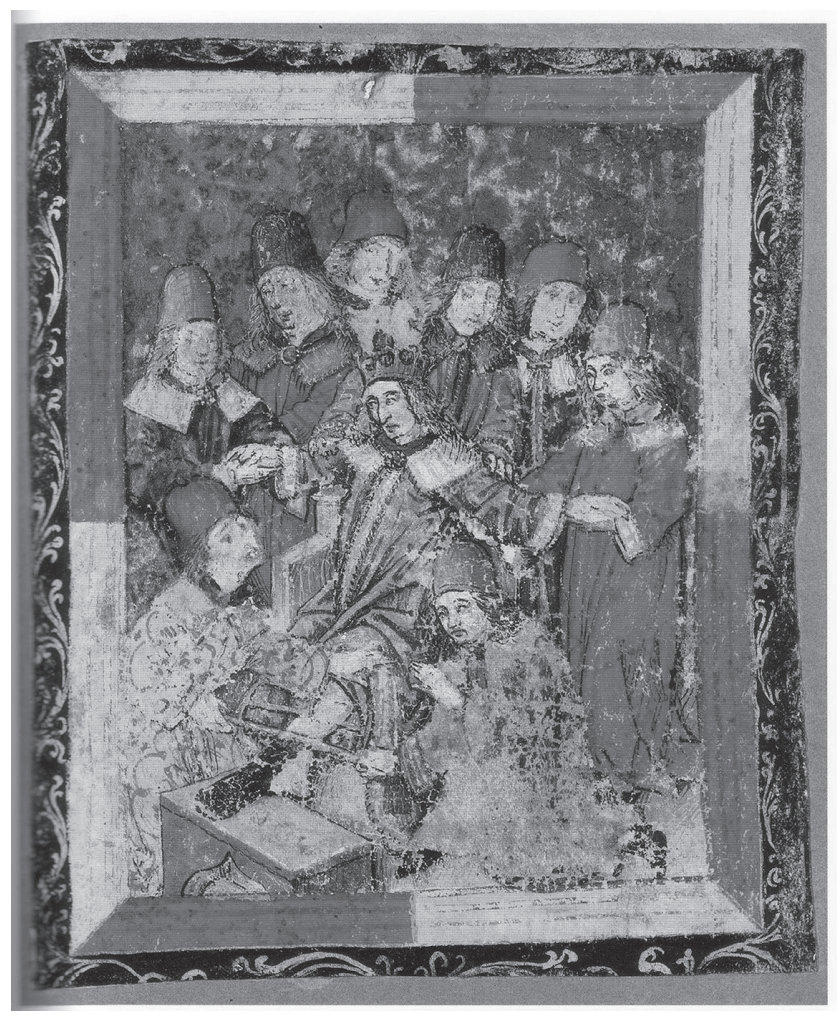

Figure 11.2 Anonymous, The Leg Amputation of Friedrich III, watercolour on paper, c.1493. Vienna, Graphische Sammlung Albertina, Min. 22475.

It is in this fact that the first sense of these objects' potential as sentient agents emerges. Where ornament does appear, it is almost always organic and extremely animated. ${ }^{11}$ Patterns gravitate towards the foliate, like the petal-shaped gilding and vine-scroll inlay of damascened examples, now in the Wellcome Collection (Figure 11.3). Several others sport animal features, hawk-headed handles or frilled elephantine trunks that spiral out from the main body of the design to energise the saw. Human faces abound too, in both extant saws and their printed designs, morphing eloquently from handles and joints. ${ }^{12}$ One particularly vivid sixteenth-century example from the Science Museum in London includes polished stone-set eyes designed to catch the light, flashing a wink at its handler upon movement (Figure 11.4). Others still seek to reflect the animalistic actions of the saw itself: in an ivory-handled saw from the collections of the Science Museum, London, two fishy creatures hold the blade in place, their eyes formed from the tool's locking bolts and their mouths grinning wide to bear the jagged shapes of the blade beneath, the blade's teeth posing as their own. ${ }^{13}$ Such orally-fixated animation is especially fitting given that late medieval surgical treatises often designated the act of surgery itself as a 'biting' craft, with writers returning repeatedly to the action of 'chewing', 'munching' and 'gnawing' in their texts to describe the diseases, surgical operations and surgery's own instruments. ${ }^{14}$ 


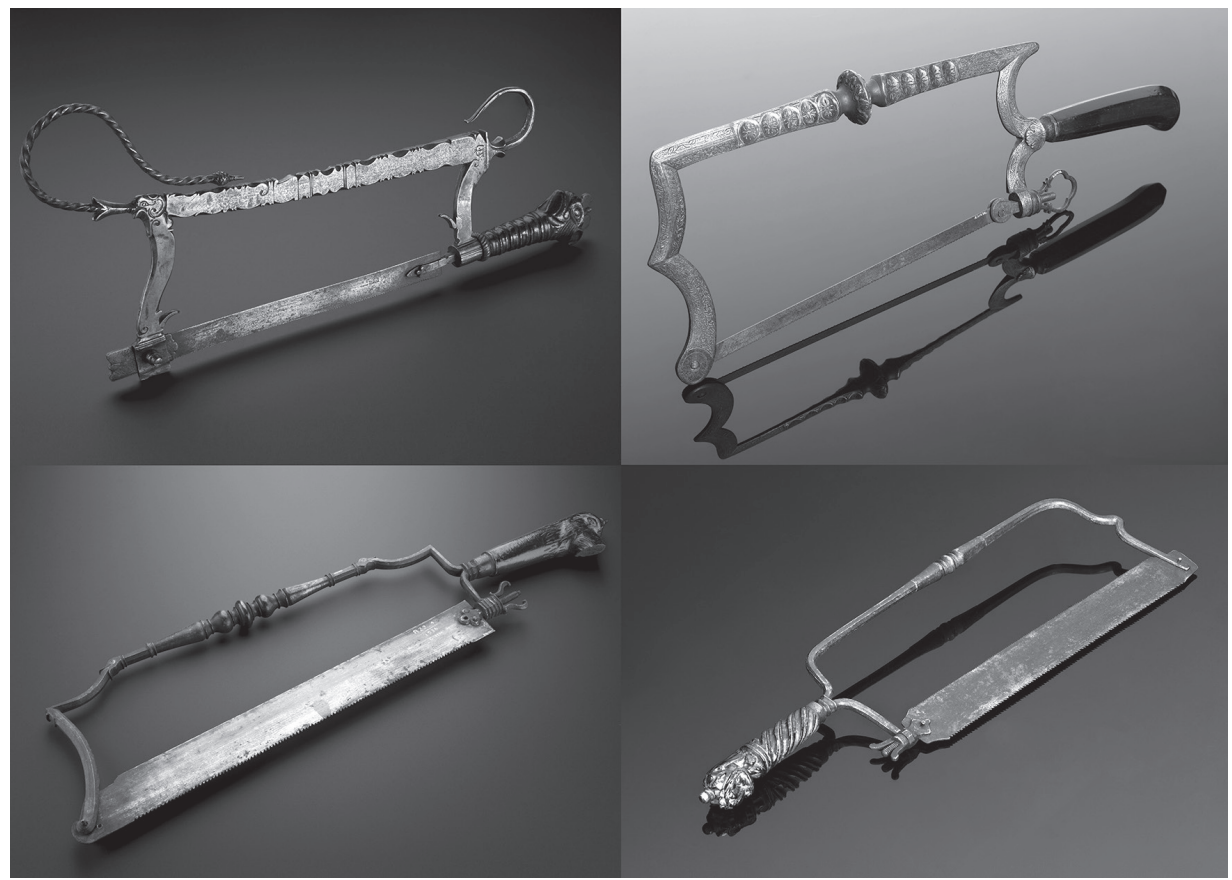

Figure 11.3 Four surgical saws, iron, steel, and gilded details with wooden or metal handles, late fifteenth and sixteenth centuries. London, Wellcome Collection (long-term loan from Science Museum, Hamonic Collection), object numbers (clockwise from upper-left): A241432, A121436, A135416, A121431.

This ingestative idea likewise aligns with more imaginative conceptions of the saw extant in Middle English writing, for these tools could not only look and bite but could also be made to speak. Uniquely preserved in a manuscript in the Bodleian Library in Oxford is a short poem, now titled The Debate of the Carpenter's Tools. ${ }^{15}$ Here, a gaggle of animated objects from a woodworker's bench debate the best way for their master to achieve prosperity and, more importantly, how their furious work might keep up with his rapacious habit for drink. After disputations from the axe, the brace, the compass, and others, the saw eagerly joins the chorus, reprimanding the compass as an apologist for his inebriated master:

It is bote bost pat pou doyst blow.

For thofe pou wyrke bothe dey and nyght,

He wyll not the, I sey pe ryght.

He wones to nyghe pe alewyffe

It is but boast that you do blow.

For though you work both day and night,

He will not prosper, I rightly say.

He lives too near the ale-wife ${ }^{16}$ 


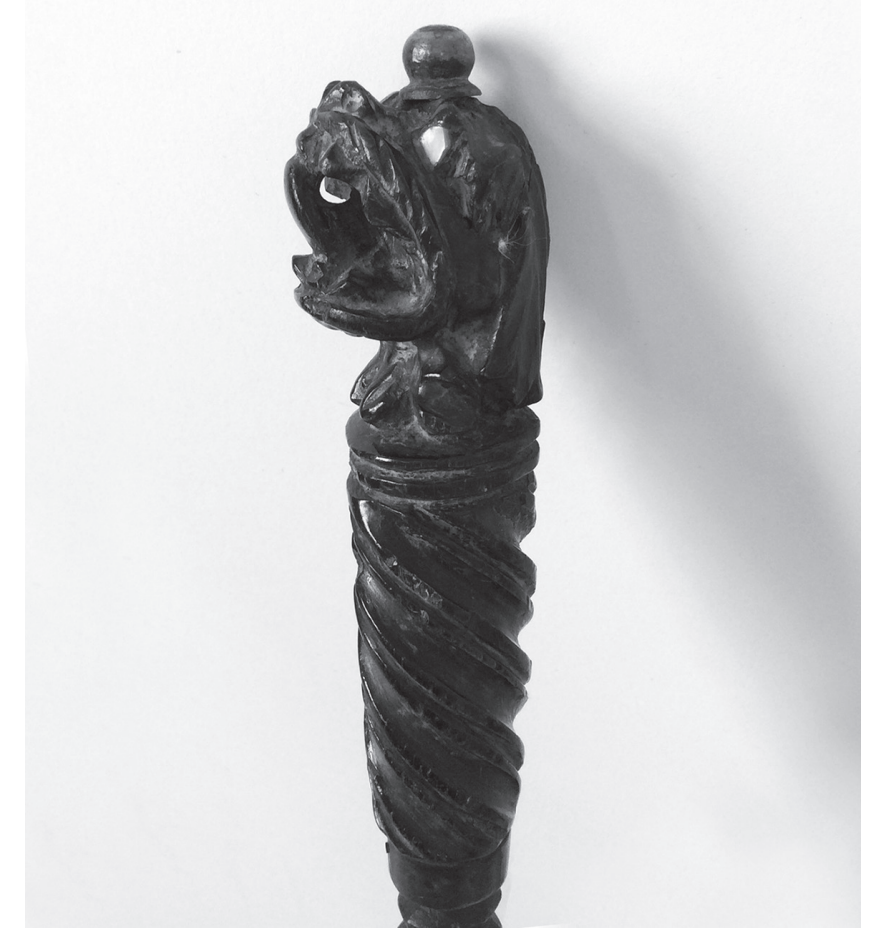

Figure 11.4 Detail of the handle of a bow-frame amputation saw, steel and ebony with inset reflective eyes. London, Science Museum, Hamonic Collection, object number A135416.

Recourse to drink, concludes the instrument, is hardly thriving. The carpenter's saw, just like the surgeon's, stood for hard toil and committed craft, embodying artisanal loyalty and animated canny.

Presented in this manner, the agency of the surgical saw - the activity of the object in the details of its decoration - might appear to be metaphor alone: the animals amid its metal or its voice in support of its master are poignant, even humorous, but not actual mechanical interventions. Yet, uniquely in these saws, there appear also to have been more concrete forms of sentience built into their actual ergonomics.

Fundamentally, almost all surviving saws are deeply uncomfortable to hold. Try to pick up any of the examples in Figure 11.3 and their short handles swiftly guide the user's fingers not into neatly-grooved, comfortable grips, but into the very jaws of its animated decoration. They chew and peck at the surgeon, especially as his grip saws aggressively back and forth through tough human tissue and bone. ${ }^{17}$ Anthropologist Tim Ingold has suggested that by offering an instinctive grasp, otherwise inanimate tools are somehow vivified through ergonomics; they gain the capacity to direct their own use, or at least extend an intended pattern of use as crafted into them by their makers. ${ }^{18}$ Couple this idea with a surgical saw's uncomfortable handling and their message quickly morphs into one of resistance. Their writhing foils, frills and 
decorative heads turn their biting activities not just towards the patient - being sawn away by the blade's teeth - but towards their surgical handlers too.

One simple solution to these apparently uncooperative saws is to suggest that such elaborate objects were never really designed to be used: covered in aggressive and awkward detail, they were visual pieces not functional ones. Yet this seems specifically not to have been the case. Various fifteenth- and sixteenth-century surgical sources present comparatively accurate images of amputation scenes, with printed instructional manuals showing elaborate saws in full swing (Figure 11.5). ${ }^{19}$ Several textual sources, too, suggest that an uncomfortable and aggressively rendered handle was something known and accepted by medieval and early modern surgeons, and about which they and their patients complained on a regular basis. The fourteenth-century French surgeon Guy de Chauliac recommended covering the patient's eyes with a cloth so that they would not be offended by the sight of the operation's elaborate equipment, and by the sixteenth and seventeenth centuries surgeons like John Woodall or Jacques Guillemeau were actually calling for the simplification of saw designs, not only because they were uncomfortable to hold, but because their decorative frills were inclined to catch and tear the patient's skin. ${ }^{20}$

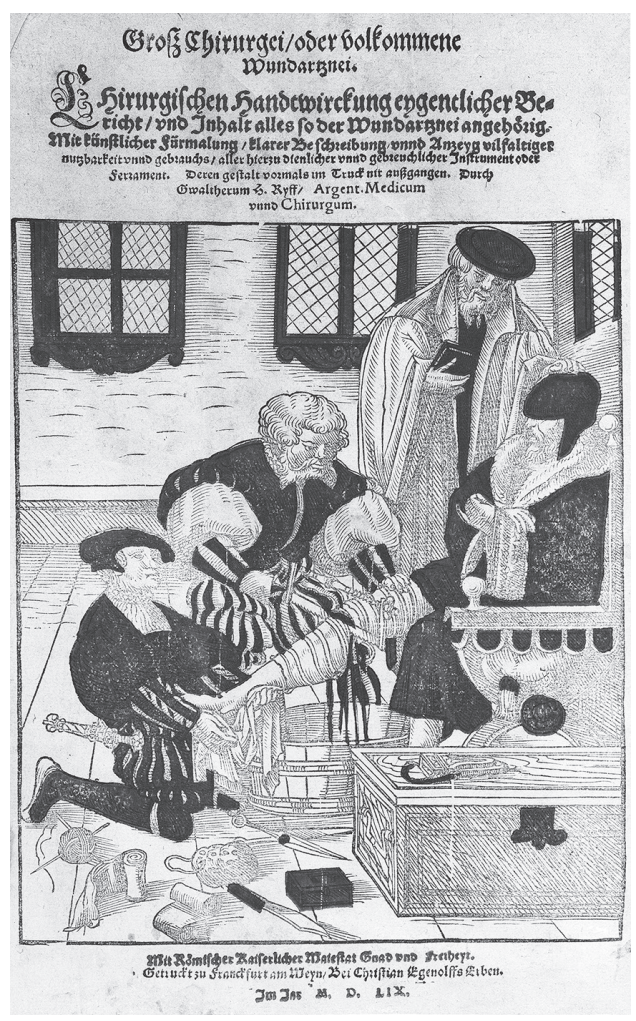

Figure 11.5 Frontispiece to Walther Ryff, Gross Chirurgei oder volkommene Wundartznei (Frankfurt: Christian Egenolff, 1559). London, Wellcome Library, EPB/D $5677 / \mathrm{D}$. 


\section{4}

Surgical Saws and Cutting-Edge Agency

A dichotomy thus emerges between ergonomics and practical use on the one hand, and ornament and decoration on the other. In fact, we might begin to see these saws more subtly as mediators between a number of different needs within the realm of the surgical craft, including more socially potent issues of ownership and display. An image from the printed work of German battlefield surgeon Hieronymus Brunschwig, his Buch der Cirurgia (1497), is thought to be the earliest surviving depiction of a so-called surgical armamentarium - an armoury of the surgeon's tools - a common tradition carried into the more widespread surgical imagery of the later sixteenth century, for example Andreas Vesalius' De humani corporis fabrica (Figure 11.6). Presented with aggrandising clarity, in these images we see a boldly outlined gathering of instruments hanging about a folding wooden structure or scattered atop the operating table: knives, scissors, syringes, probes, arrow and bullet extractors, and, always prominent among them, the amputation saw. Taking care to make clear the details of their complex handles and hinges, saws in these armamentaria are presented as a prominent and important element of surgery's public face, their presence designed to be as informative of a surgeon's practice as the actual accounts of treatments described in the texts alongside them.

These visualisations also emphasise the sheer financial value of these tools, and the presence of instruments in the wills of craftsmen confirm their significant expense. A series of early sixteenth-century English testaments noted by the London Consistory

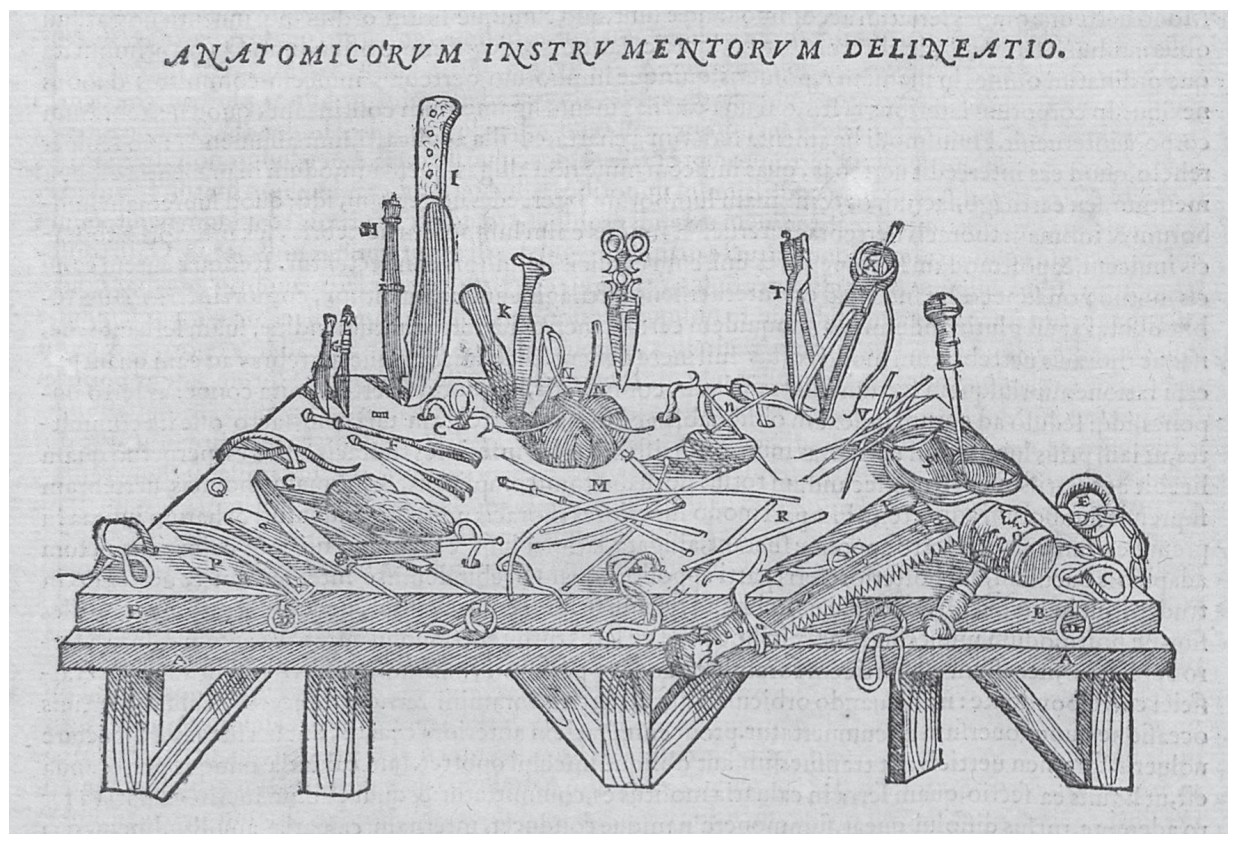

Figure 11.6 Anatomical instruments displayed on a table, including an amputation saw. Andreas Vesalius, De Humani Corporis Fabrica, reproduced from the original 1543 volume by Franciscius \& Criegher in Venice, 1568. Heidelberg, Universitätsbibliothek, urn:nbn:de:bsz:16-diglit-129406. 
Court preserve several such bequests: Nycholas Grove, barber, singles out his 'gryndyng stonys' [grinding stones] and 'a case with rasers' [razors] to be passed on to his family and friends; the tailor Robert Fosster lists first among his possessions 'a shop borde and 2 payer of sherres [shears] and 2 pryssyng yerns [pressing irons]' (at 3s. $4 \mathrm{~d}$. also among his most valuable possessions); and Antony Copage, a surgeon, requests that all his '“enturmentes of stele"' [instruments of steel] be left to his servant George on the condition that 'he be of the same crafte'. ${ }^{21}$ The latter suggests particularly well the twinned financial and emotional power of Copage's tools, whose prominent inclusion suggests a parity with his books, finest clothes and the personal tokens left to his wife. Brunschwig or Vesalius' tools are, after all, presented complete with their etched grips, animalistic foliate-ended handles and cuir bouilli cases, features that again link the manual craft of surgery back to the expensive output of other artisans who dwelt in the same socially and intellectually ambitious milieu. Extant saws bear little sign of their individual makers, besides the often generic or untraceable stamps on their blades, yet we must remember that such complex tools were doubtless crafted by master makers, the decidedly delicate constructions of expert cutlers, goldsmiths and later (in an expanding early-modern marketplace) increasingly niche instrument-makers. ${ }^{22}$ As the elaborate trade cards of such craftsmen grew to show, early-modern makers were as intricately tied to the trajectory of their objects as owners like Copage. ${ }^{23}$ And earlier medieval and Renaissance craftsmen too, although largely anonymous, were similarly bound to their tools. A cast bronze epitaph of a Nuremberg instrument maker known only as Voyott, for example, takes particular care in the detailing and conspicuous display of his tools, a maker forever memorialised by his instruments. ${ }^{24}$ Above a text extolling his skill, a cluster of Voyott's specialities are suspended within a wreath: gouge, chisel, hammer and - standing like a central cenotaph within the frame - an upended saw.

By displaying the tools of their trade within their texts and on their tombs, such craftsmen were conceding that their objects possessed a more intricate, symbolic agency. For the surgeon, presenting one's inventory proved that they were in possession of the tools actually needed to perform an operation, an aspect more important than it sounds. Even in 1554, by which time the practices of Vesalian exploratory anatomy were well underway in some academic quarters, a woodworker named Galop is recorded as being called to St Bartholomew's Hospital in London to 'practyse surgery' on a patient whose limb needed amputating with a saw, the man requested not for his anatomical expertise but merely his possession of the right equipment. ${ }^{25}$ As a guild-oriented craft it was particularly important for surgeons to control access to instruments, for this was in a very real sense a method of controlling practice. Possession of tools, therefore, conferred both social standing and professional power, active agents within surgical social circles and deeply intertwined with a sense of group technical command. Embodying both action and expertise, saws were non-textual carriers of such artisanal understanding, the display of instruments directly linked to the display of surgical knowledge.

I began with Paracelsus' blurring of the body and machine, and in closing I want to briefly return to this idea to illustrate one more direction in which the agency of these saws can take us, perhaps a quieter and more contemplative one. As Mary Carruthers has so aptly shown, memory itself was conceived of in the later Middle Ages as a machina, a 'machine for performing the tasks of invention'. ${ }^{26}$ Certainly depictions like Voyott's or Brunschwig's can be seen as evocative, memorialising even, presented 
in a reified style comparable to contemporary visual inventories of relics in church treasuries. ${ }^{27}$ But it is not only a comparison with holy gatherings that remind us of the significant position of tools within the upper echelons of early modern society.

In 1544, August the Strong, Elector of Saxony, commissioned the renowned metalworker Leonhard Danner to create an extensive series of exceptional tools. ${ }^{28}$ Still preserved in museums in Dresden and Paris, they are remarkable in their breadth and skill: a bench for drawing wire inlaid with delicate, wooden intarsia scenes of the processing court, engraved axes, hammers, clamps, planes and an enormous gilded saw intricately etched with decorative motifs and coats of arms. But Danner's tools were explicitly not for use; they were display pieces designed to take their place within August's ever-expanding and much-famed Wunderkammer. ${ }^{29}$ Accompanying the Elector's cornucopia of symbolic objects and conversation pieces, from gold-set nautilus shells to mother-of-pearl model ships, Danner's tools were included in part for the sheer craft of their elegant making. But through their inclusion within the discursive and contemplative space of the Wunderkammer, they also served to intellectualise craft and embody a group of idealised wielders for which they came to stand. August was, of course, not alone in this collecting obsession. Tools of work, including saws, featured in contemporary collections from Christian III of Denmark to the Holy Roman Emperor Kaiser Rudolf II, and in all of these collections the users of such instruments - woodworker and surgeon alike - were evoked in a learned milieu which sought to reify the world of good Christian work. In such idealised modes of looking and thinking, we can read a certain sense of craft-memory, perhaps even craft-nostalgia. This, after all, came at a broad historical moment when certain processes of manufacture were modernising across Europe. Hydraulically operated sawmills were flourishing, automatous pieces of machinery with their own clear kinetic agency. Set besides these machines, the position of the manual saws as specifically hand-held, manipulable objects was perhaps what made them particularly prized in the Wunderkammern..$^{30}$ Coincident with a tangible moment of human disengagement with such tools, we can begin to see their uncomfortable and convoluted form, insistently spiky and unpleasant in the surgeon's hands, as a deliberate and constant reminder of their almost antiquated 'hand-held-ness'.

Surgical saws can be seen as both participants and eloquent commentators on the social worlds they actively witnessed. Their diverse forms of agency saw them fluctuate between ideas of intense beauty and intense function, a group of objects whose liminal liveliness makes them troublesome for historians to pin down. It seems appropriate, then, to leave the last word to one of these object agents themselves, another speaking surgical saw from sixteenth-century Germany, now in Vienna. Punning on the double meaning of the German spruch, translating as both 'saw' and 'motto', a short poetic verse etched onto its bow reminds us of the eloquence and agency, the fear and hope, that such saws could inspire:

\section{Spruch: Grausam sieht mein Gestalt herein, mit Angst, Schwäche und großer Pein, wann das Werk nun ist vollendt das trauern sich in Freude wendt.}

Motto: Cruel looks are in my shape here lain, with fear, weakness and great pain, But when the work is then all ended, mourning into joy is rendered. ${ }^{31}$ 


\section{Notes}

1 Theophrastus Bombast von Hohenheim (commonly called Paracelsus), Die Große Wundarznei (Augsburg: Heinrich Steiner, 1536): 10-11. My translation. For Paracelsus' complete works, see Karl Sudhoff, Paracelsus: Sämtliche Werke, 14 vols (Munich: R. Oldenbourg, 1929-33), digitised as part of the University of Zurich's 'Paracelsus Project', http://www.paracelsus.uzh.ch/index.html (accessed 25 September, 2015). For biographies of Paracelsus, see either the classic work by Walter Pagel, Paracelsus. An Introduction of Philosophical Medicine in the Era of the Renaissance, 2nd edn (Basel: Karger, 1982), or more recent work by Charles Webster, Paracelsus: Medicine, Magic, and Mission at the End of Time (New Haven, CT and London: Yale University Press, 2008).

2 Marie-Christine Pouchelle, Corps et chirurgie à l'apogée du Moyen Age (Paris: Flammarion, 1983), later translated into English as The Body and Surgery in the Middle Ages (New Brunswick, NH: Rutgers University Press, 1990): 102ff. For Mondeville's original text in full, see Julius Pagel, Die Chirurgie des Heinrich von Mondeville (Berlin: Hirschwald, 1892). The Catalan surgeon Arnau de Vilanova also stressed similar metaphorical links between surgery and craft: Mirko D. Grmek, 'Arnaud de Villeneuve et la médecine du travail', Yperman, Bulletin de la Société belge d'histoire de la médecine, 8 (1961): 1-3. On Classical ideas of metabolism, see C.-E. A. Winslow and R. R. Bellinger, 'Hippocratic and Galenic Concepts of Metabolism', Bulletin of the History of Medicine, 17 (1945): 127-36.

3 Vigevano's mechanical and anatomical writings are found in a group of treatises dedicated to King Philip VI of France: first the Texaurus regis Francie aquisitionis terre sancte de ultra mare (1335), including designs for wagons, ships and siege towers (Paris, Bibliothèque nationale de France, MS Latin 11015); and second, the Anathomia designata per figures (1345), including 24 anatomical plates, 18 of which are lost (Chantilly, Musée Condé, MS 334). On Vigevano's anatomical writings, see Ernest Wickersheimer, Anatomies de Mondino de' Luzzi et de Guido de Vigevano (Paris: Droz, 1926). On Vigevano's designs in the history of engineering, see Giustina Ostuni, Le macchine del Re. Il Texaurus Regis Francie di Guido da Vigevano (Vigevano: Diakronia, 1993); Wolfgang Lefèvre (ed.) Picturing Machines, 14001700 (Cambridge, MA: MIT Press, 2004), especially contributions by David McGee and Rainer Leng (chapters 2 and 3).

4 Pamela H. Smith, The Body of the Artisan. Art and Experience in the Scientific Revolution (Chicago: Chicago University Press, 2004): 82ff. For a more regionally specific case study of this phenomenon in early-modern Turin, see Sandra Cavallo, Artisans of the Body in Early Modern Italy (Manchester and New York: Manchester University Press, 2006). On objects caught in related artisanal debates, see Paula Findlen (ed.), Early Modern Things: Objects and their Histories, 1500-1800 (New York: Routledge, 2012).

5 For a general overview of pre-modern surgical equipment, see John Kirkup, The Evolution of Surgical Instruments. An Illustrated History from Ancient Times to the Twentieth Century (Novato, CA: Norman, 2006). This book gathers and refines Kirkup's various earlier articles on aspects of medical instrumentation. Normally organised typologically or by period, these were published as 'The History and Evolution of Surgical Instruments', parts I to XII in the Annals of the Royal College of Surgeons between 1981 and 2004. On earlier instruments, see Stefanos Geroulanos, 'Chirurgische Instrumente: Altertum \& Byzanz', Archives internationales d'histoire des sciences, 60 (2010): 13-32. For medieval tools more generally, see Johan David, L'outil, Typologie des Sources du Moyen Age Occidental 78 (Turnhout: Brepols, 1997).

6 On the contested relationship between medical instruments and the historical enterprise, see Ghislaine Lawrence, 'The Ambiguous Artifact: Surgical Instruments and the Surgical Past', in Medical Theory, Surgical Practice: Studies in the History of Surgery, ed. Christopher Lawrence (London: Routlege, 1992): 295-314; James M. Edmonson, 'Learning from the Artefact: Surgical Instruments as Resources in the History of Medicine and Medical Technology', Caduceus, 9 (2) (1993): 87-98; Gretchen Worden, 'Steel Knives and Iron Lungs: Medical Instruments as Medical History', Caduceus, 9 (2) (1993): 111-18.

7 For Gell on agency, see his seminal article 'Vogel's Net: Traps as Artworks and Artworks as Traps', Journal of Material Culture, 1 (1996): 15-38, and the more substantial extension of this idea in his Art and Agency: An Anthropological Theory (Oxford: Clarendon Press, 1998). For a complex historiographical study of the emerging anthropological interest in 
'agency', see Webb Keane, 'Self-Interpretation, Agency, and the Objects of Anthropology. Reflections on a Genealogy', Comparative Studies in Society and History, 45 (2) (2003): 222-48. For eloquent introductions to the use of Maurice Merleau-Ponty's phenomenology in considering objects, see Amelia Jones, 'Meaning, Identity, Embodiment: The Uses of Merleau-Ponty's Phenomenology in Art History', in Art and Thought, eds Dana Arnold and Margaret Iversen (Malden, MA and Oxford: Blackwell, 2003): 72-90; Michael Ann Holly, 'Iconology and the Phenomenological Imagination', Ikon, 7 (2014): 7-16.

8 John Kirkup, A History of Limb Amputation (London: Springer, 2007).

9 See K. Zimmerman (ed.), One Leg in the Grave Revisited: The Miracle of the Transplantation of the Black Leg by the Saints Cosmas and Damian (Eelde: Barkuis, 2013). On the spectre of amputation in a literary context, see David S. King, 'Learning from Loss: Amputation in Three Thirteenth-Century French Verse Romances', Modern Philology, 110 (2012): 1-23.

10 See Daniel Carlo Pangerl: “Item als man dem kayser Fridrichen sin fuß abschnitt”. Die Beinamputation an Kaiser Friedrich III. am 8. Juni 1493 in Linz', Sudhoffs Archiv, 94 (2010): 195-200. The account is now divided into two parts: the first is a handful of pages outlining the operation (Stuttgart, Württembergische Landesbibliothek, Cod. med. et phys. 208 , fol. $71 \mathrm{v}-72 \mathrm{v}$ ); the second is an anonymous painting of the event that perhaps acted as a frontispiece to the account (Vienna, Graphische Sammlung Albertina, Min. 22475, here Figure 11.2).

11 For a consideration of surgical tools in the realm of sculpture, see Marie-Veronique Clin, 'Surgical Instruments as Art Objects', in Antique Tools and Instruments from the Nessi Collection (Milan: 5 Continents, 2004): 103-14.

12 See, for example, the anthropomorphic handle design of the amputation saw heading chapter 13 of Ambroise Paré, Dix livres de la chirurgie, avec le magasin des instrumens necessaires à icelle (Paris: Jean Le Royer, 1564), n.p. On Paré's instruments in context, see Alain Ségal, 'L'instrumentation chirurgicale à l'époque d'Ambroise Paré', Histories des sciences medicales, 25 (1991): 109-26.

13 The saw is object number A121435, Science Museum, London (formerly Hamonic Collection).

14 For more on this, see Jack Hartnell, 'Tools of the Puncture. Skin, Knife, Bone, Hand', in Flaying in the Premodern World: Practice and Representation, ed. Larissa Tracey (Rochester, NY: Boydell \& Brewer, 2017): 20-50.

15 Oxford, Bodleian, MS Ashmole 61.1. See Edward M. Wilson 'The Debate of the Carpenter's Tools', Review of English Studies, 38 (1987): 445-70. The poem is reproduced in George Shuffelton (ed.), Codex Ashmole 61: A Compilation of Popular Middle English Verse (Kalamazoo: Medieval Institute Publications, 2008), digitised here: http://d.lib.rochester.edu/ teams/text/shuffelton-codex-ashmole-61-debate-of-the-carpenters-tools (accessed 21 May 2016). It also features in John W. Conlee (ed.), Middle English Debate Poetry: A Critical Anthology (East Lansing, MI: Colleagues Press, 1991): 222-35.

16 Wilson, 'The Debate of the Carpenter's Tools', 456. My translation.

17 For this phenomenon in surgical knives, see Hartnell, 'Tools of the Puncture'. For later evocations of similar ideas see Katherine Rowe, “'God's Handy Worke”. Divine Complicity and the Anatomist's touch', in The Body in Parts. Fantasies of Corporeality in Early Modern Europe, eds David Hillman and Carla Mazzio (London: Routledge, 1997): 285-309.

18 Tim Ingold, 'Tools, Minds and Machines: An Excursion in the Philosophy of Technology', Techniques and Culture, 12 (1989): 151-76. For a further example of anthropological approaches to tools and technology, see Tim Ingold, 'Walking the Plank: Meditations on a Process of Skill', in Defining Technological Literacy: Towards an Epistemological Framework, ed. John R. Dakers (New York: Palgrave Macmillan, 2006): 65-80; Alessandro Cesati, 'Civilisation and Its Tools', in Antique Tools and Instruments from the Nessi Collection (Milan: 5 Continents, 2004): 113-61.

19 While such images cannot be taken as verbatim sources for surgical operations, they do clearly show a significant commitment to verism and accuracy; moreover, they are plentiful, and are all consistent in showing the elaborate details of instrumentation. For just some of the many examples, see instruments in Brunschwig's Buch der Chirurgia (Strasbourg: Johann Grèuninger,1497), discussed below; the table of instruments in Andreas Vesalius, De humani 
corporis fabrica libri septem (Basel: Oporini, 1543), here Figure 11.6; the frontispiece of Walter Ryff, Gross Chirurgei, oder volkommene Wundartznei (Frankfurt: C. Egenolff, 1559), here Figure 11.5; later editions of Wilhelm Fabry (Hildanus), De gangraena et sphacelo (Cologne: Kerschedt, 1593); or the frontispiece to Jacques Guillemeau, Le chirurgie françoise recueillie des antiens médecins et chirurgiens (Paris: Nicolas Gilles, 1594).

20 Edouard Nicaise, La Grande Chirurgie de Guy de Chauliac (Paris: Félix Alcan, 1890); Kirkup, Surgical Instruments, 381.

21 These wills have been published, with an introduction, as London Consistory Court Wills, 1492-1547, ed. Ida Darlington (London, 1967). The will of Grove appears as record 183, Fosster as 156 and Copage as 108.

22 On later industries of instrument-making, see Larry Stewart, 'Science, Instruments, and Guilds in Early-Modern Britain,', Early Science and Medicine, 10 (3) (2005): 392-410; Luigi Nessi, 'Objects of Use and Subjects of Representation', in Antique Tools and Instruments from the Nessi Collection (Milan: 5 Continents, 2004): 9-41.

23 See, for example, the later trade card of a French instrument-maker $c .1700$ who was located, according to his card, 'at the Crowned Pomegranate' (Waddesdon Collection, 3686.1.2.2); or the card, complete with elaborate surgical saw, of Henry Patten, 'Razor maker at the Saw and Crown in Middle Row Holborn', reproduced in Ambrose Heal, London Tradesmen's Cards of the XVIII Century: An Account of their Origin and Use (Toronto: General Publishing, 1968). See also, Phillipa Hubbard, 'The Art of Advertising: Trade Cards in Eighteenth-Century Consumer Cultures', PhD, Warwick University (2009).

24 On Voyott, see Nessi, 'Objects of Use', 37ff; Walther Bernt, Altes Werkzeng (Munich: Callwey, 1939): 128-9.

25 R. T. Beck, The Cutting Edge: Early History of the Surgeons of London (London: Lund Humphries, 1974): 8.

26 Mary Carruthers, The Craft of Thought: Meditation, Rhetoric, and the Making of Images, 400-1200 (Cambridge and New York: Cambridge University Press, 1998): 22-3.

27 See, for example, the relics and reliquaries of Friedrich III, Elector of Saxony, represented in woodcuts by Lucas Cranach the Elder (c.1472-1553) in the well known Wittenberger Heiltumsbuch, printed only eight years after Brunschwig's text (Wolfenbüttel, Herzog August Bibliothek, 154.2 Theol. 1).

28 Martina Minning, 'Werkzeug in der Dresdener Kunstkammer', in Die kurfürstlich-sächische Kunstkmmer in Dresden. Geschichte einer Sammlung, eds Dirk Syndram and Martina Minning (Dresden: Sandstein Verlag, 2012): 167-83. On the particularly practical emphasis of collecting in Dresden, see Helen Watanabe-O'Kelly, 'Kunstkammer, Library, and Chamber of Anatomy: The Management of Knowledge at the Dresden Court in the Early Modern Period', in Ways of Knowing, ed. Mary Lindemann (Leiden: Brill, 2004): 53-66. On August and his collection more generally, see Dirk Syndram and Antje Scherne (eds), Princely Splendor: The Dresden Court 1580-1620 (Dresden and New York: Metropolitan Museum of Art/Staatliche Kunstsammlungen Dresden, 2004).

29 On the Wunderkammer more generally, see Neil Kenny, Curiosity in Early Modern Europe: Word Histories (Wiesbaden: Harrassowitz, 1998); Horst Bredekamp, The Lure of Antiquity and the Cult of the Machine: The Kunstkammer and the Evolution of Nature, Art, and Technology, trans. Allison Brown (Princeton, NJ: Marcus Weiner, 1995); Oliver Impey and Arthur MacGregor (eds), The Origins of Museums: The Cabinet of Curiosities in Sixteenthand Seventeenth-Century Europe (Oxford: Oxford University Press, 1985); Thomas DaCosta Kaufmann, 'Remarks on the Collection of Rudolf II: The Kunstkammer as a Form of Representation', Art Journal, 38 (1) (1978): 22-8.

30 On early modern mechanisation, see Jonathan Sawday, Engines of the Imagination: Renaissance Culture and the Rise of the Machine (London: Routledge, 2007). On early plans for hydraulic saws, see Jean-Pierre Adam and Pierre Varène, 'La scie hydraulique de Villard de Honnecourt et sa place dans l'histoire des techniques', Bulletin Monumental, 143 (4) (1985): 317-32. For a brief and accessible account of the development of saw mechanisation, see the volume produced to celebrate the bicentenary of saw-makers Spear \& Jackson Ltd: P. d'A. Jones and E. N. Simons, Story of the Saw (London: James Cond, 1961).

31 Reproduction in Bernt, Altes Werkzeng, no. 96. My translation. 

Part 5

The Agency of Things and Human Agency 



\title{
12 The Boots of Saint Hedwig Thoughts on the Limits of the Agency of Things
}

\author{
Jacqueline E. Jung
}

Covering a full folio of the great fourteenth-century illuminated codex recounting her life story (the Vita Maior beatae Hedwigis, in the manuscript familiarly known as the Hedwig Codex), the holy duchess Hedwig, patron of Silesia (d.1242, can.1267) could well be regarded as the emblem of medieval art history's material turn (Figure 12.1). ${ }^{1}$ Beneath a microarchitectural canopy, the luxuriously garbed saint dominates the page's surface with her physical presence, captivating both her diminutive

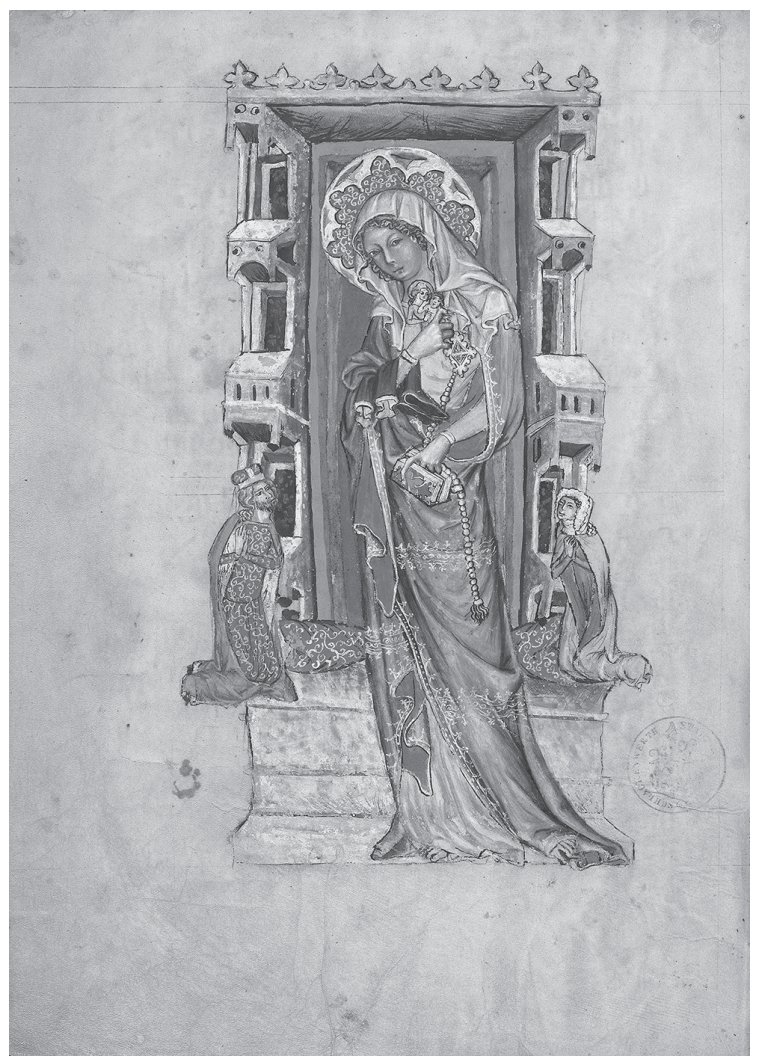

Figure 12.1 Vita beatae Hedwigis (Hedwig Codex), Silesia, 1353, fol. 12v: St Hedwig with Duke Ludwig of Liegnitz and Duchess Agnes. Los Angeles, J. Paul Getty Museum, Ludwig XI 7. 


\section{4}

The Boots of Saint Hedwig

descendants who gaze at her from the borders and the living viewers toward whom she herself looks. Complementing Hedwig's apparent physical substance is her adherence to material stuff. The fingers of her left hand grapple with the pages of a small prayerbook, while her right hand clutches to her chest an ivory statuette of the Virgin and Child. A string of prayer beads stretches between these two things, as if to substantiate the voice that would convey the words from the manuscript to their divine recipients.

As devotional objects and as subjects of tactile encounter, Hedwig's statuette and prayerbook have received much attention in recent scholarship. ${ }^{2}$ Easier to overlook are the soft, fur-lined, brown leather boots that lie slung across her right forearm. This is in part because they are camouflaged against the cascading folds of her cloak, and in part because they simply do not fit into the expected devotional toolkit of the late medieval holy woman. It is these boots that I wish to focus on here, for they call attention both to the power of material objects as mediators of the sacred and, paradoxically, to the limits of the 'agency of things.' As we shall see, they point back, in subtle but palpable ways, to the human being - a conglomeration of will, actions, and physical presence - as the creative force effecting changes in the self and the social sphere. Before exploring the role shoes (and other things) played in the legend of St Hedwig, let us consider these things for what they are.

\section{On Shoes and Being Worn}

What, after all, could be more powerfully eloquent objects than shoes? Running the gamut between necessity and frivolity, shoes speak to their wearer's myriad contacts with both the physical and the social world. To those who have gone without, they promise protection for the body's most hard-working extremities. ${ }^{3}$ To those who have plenty, there is never enough. Fancy designer shoes, we know from recent history (witness Imelda Marcos) and popular culture (Sex and the City), are the exemplary objects of commodity fetishism, a role they have enjoyed at least since the age of Louis Quatorze. ${ }^{4}$ When, at the end of the aforementioned television series, Carrie Bradshaw's paramour slipped a blue satin pump on her foot as a proposal of marriage, this (easily ridiculed) action played into a deep tradition linking footwear with eros. The Cinderella story from which the scene derived represents but one instantiation of a larger set of expectations and practices found in Judaic, Muslim, pagan, and early medieval Christian cultures. ${ }^{5}$ To bestow a shoe upon a woman was in early Germanic society an act of both generosity and subjugation: this gift, after all, provided an interface between woman and world, enveloping her body precisely where it made physical contact with the ground. To accept the shoe was to accept the husband and his claims to mediation. Woe to the man whose prospective bride deemed his gift of shoes ill-fitting and sent them back! He was on a par with the henpecked Jewish husbands who, according to a Yiddish saying, 'wore the slippers' in the house, letting their wives take control of matters properly left to men. ${ }^{6}$

In the Judeo-Christian tradition, shoes (or, more often, sandals) bore great symbolic weight - and of course so did their removal. We might think here of God's command to Moses in Exodus 3: 5 to 'put off thy shoes from thy feet' when approaching holy ground. The transfer of shoes between one man and another signaled the conclusion of a successful business or economic transaction, while to remove someone else's shoe was an act of self-submission; the synoptic Gospels all have John the Baptist predict that 'one will cometh after me . .., the latchet of whose shoes I am not worthy to stoop down and loose[n]' (Mk 1: 7). ${ }^{7}$ This implies that Jesus was expected (pace the early Franciscans) to traverse the harsh terrain of Judea in some kind of protective footgear. ${ }^{8}$ 
In biblical times and beyond, having one's shoes removed by another person was the prerogative of the powerful, one reason why Jesus's act of baring and washing his disciples' feet on Maundy Thursday was such a potent act. ${ }^{9}$ Conversely, choosing to tread the earth barefoot signified a relinquishment of authority. God commanded Isaiah to 'walk naked and barefoot' to signal the impending defeat of the Egyptians and Ethiopians by the Assyrians (Is. 20: 2). And taking off one's shoe to throw at another was in antiquity - as in modern Muslim cultures - a devastating insult. ${ }^{10}$

Shoes do not seem to have been used often as projectiles in medieval Europe. At least until the mid-fourteenth century, when narrow shoes with pointed extensions called poulaines (or pikes) became all the rage, their value was chiefly practical. ${ }^{11}$ The pious service of doling out shoes to men, women, and children was part of the repertoire of legendary holy men such as Crispin and Crispianus ${ }^{12}-$ but footwear donations were not just the domain of saints. Individual wills and institutional bequests from various countries indicate that people often left shoes, along with money or food, for the local poor. ${ }^{13}$ On the thirteenth-century choir screen of Strasbourg Cathedral, the program of the Seven Works of Mercy carved in the gables was even expanded to include the distribution of new footwear to the needy! ${ }^{14}$ In that (now-lost) relief, documented in a drawing by Jean-Jacques Arhardt, a lay couple brandished a pair of ankle-high boots like trophies over the outstretched hands of barefoot beggars. ${ }^{15}$ A sermon by the Franciscan preacher Berthold of Regensburg, explaining the impossibility of saving souls from hell, gives a glimpse of both the instrumentalization of other-world visions by charlatans and the desirability of shoes on the black market: 'If someone says to you, 'I was in hell and saw your father and your mother, and [they said] you could help them [by giving over] two shoes' - believe me, you couldn't help them with all the shoes in the world.' ${ }^{\text {16 }}$

In sum: in a way that transcends time and place, shoes have symbolic value, they have aesthetic value, and they have practical value. They also possess something we might call presence value, a kind of agency as material indices of human lives. 'Working with shoes probably is one of the most difficult parts of working here,' said Jolanta Banaś-Maciaszczyk, head of the preservation department at Auschwitz, in a New York Times report on the efforts to keep intact the 'ghastly inventory' of this concentration camp. ${ }^{17}$ The approximately 110,000 shoes of Auschwitz victims are kept in massive piles behind glass, filling rooms with the vibrant relics of absent bodies. ${ }^{18}$ The power of shoes to evoke presence was harnessed, in a more artificial way, by the Hungarian film director Can Togay and sculptor Gyula Pauer, who lined a stretch of the Danube Promenade in Budapest with a row of sixty cast-iron shoes to commemorate the Jewish men and women who were shot there and left to fall into the river. ${ }^{19}$

The life that thrums within empty leather is something that philosophers have recognized at least since Heidegger reflected on Van Gogh's rustic clodhoppers in 'The Origin of the Work of Art' (1935). 'A pair of peasant shoes and nothing more' is what the picture seems to represent (Figure 12.2). And yet -

From the dark opening of the worn insides of the shoes the toilsome tread of the worker stares forth. In the stiffly rugged heaviness of the shoes there is the accumulated tenacity of her $[$ sic] slow trudge through the far-spreading and ever-uniform furrows of the field swept by a raw wind. On the leather lie the dampness and richness of the soil. Under the soles slides the loneliness of the field-path as evening falls. In the shoes vibrates the silent call of the earth, its quiet gift of the ripening grain and its unexplained refusal in the fallow desolation of the wintry field. ${ }^{20}$ 


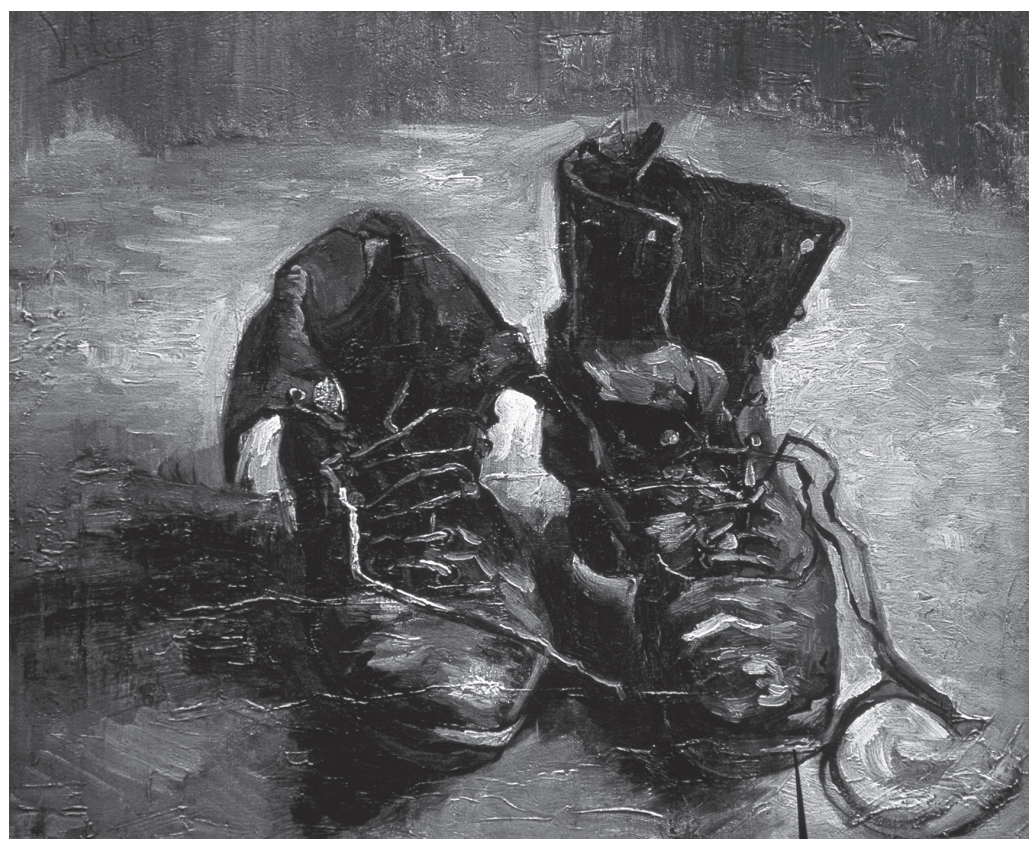

Figure 12.2 Vincent Van Gogh, A Pair of Shoes, 1886. Amsterdam, Van Gogh Museum.

Heidegger envisioned the owner as an anonymous peasant woman, a view corrected by Meyer Schapiro, who surmised that the shoes were the artist's own. ${ }^{21}$ Dietrich Schubert has recently suggested that these shoes were painted at the conclusion of Van Gogh's long journey by foot, in 1880, from his home in Belgium to the northern French town of Courrières, where he visited the painter Jules Breton. 22 This circumstance would have made the picture into a memento of what the artist regarded as a pilgrimage of deep spiritual import. However one understands them, what is clear is that the battered old shoes stand as eloquent relics - 'vieille relique,' as Van Gogh's friend Paul Gauguin described them ${ }^{23}$ - of some body's encounters with the world.

As the site where body and earth connect, shoes not only bear the traces of the world's detritus; they also, more immediately than any other variety of clothing, index the presence of the absent body itself, testifying to its unique combination of weight and mass, its health, its hurts, its distinctive gait. This fact is what makes the Auschwitz shoes so unbearable. It is also what can make shoes objects of desire. Let us listen to Thomas Hardy, an English author of fiction who was no less sensitive than Heidegger to the eloquence of things. ${ }^{24}$ In his 1872 novel Under the Greenwood Tree he gathered some rustic characters, including a cobbler, around the footwear a young woman had left behind. 'Their glances . . . converg[ing] like wheel-spokes upon the boot at [their] center,' the men admired 
this interesting receptacle of the little unknown's foot - and a very pretty boot it was. A character in fact - the flexible bend at the instep, the rounded localities of the small nestling toes - scratches from careless scampers now forgotten - all, as repeated in the telltale leather, evidencing a nature and a bias. ${ }^{25}$

This is intimate, heady stuff. Dick, the book's protagonist and the girl's eventual lover, 'surveyed it with a delicate feeling that he had no right to do so without having first asked the owner of the foot's permission.'

The cobbler proceeds to compare the lady's boot to a rough-and-tumble example nearby, noting that, despite their drastically different appearances, his specialized eyes can discern the connectedness of their wearers. 'To you, nothing,' he declares, 'but 'tis father's voot and daughter's voot to me as plain as houses.' 'I don't doubt there's a likeness,' a companion replies, 'a mild likeness - a fantastical likeness. But $I$ han't got imagination enough to see it perhaps.'

To observe familial relationships in the shapes of well-worn shoes indeed requires a combination of an eloquently empty artefact and a beholder imaginative enough to reinfuse it with presence. What both Heidegger and Hardy's men are recognizing here is what Michel de Certeau called 'the fascinating presence of absences. ${ }^{26}$ The phrase was inspired by a visit to the Shelburne Museum in Vermont, a reconstructed nineteenthcentury village where the author had seen innumerable familiar objects, polished, deformed, or made more beautiful by long use ... [displaying] the marks of active hands and laboring or patient bodies for which these things composed the daily circuits. ${ }^{27}$

Reading bodies into sewing machines or shoes is of course not merely a literary or philosophical fancy; historians of material culture do this all the time..$^{28}$ A series of excavations undertaken in London in the mid-1980s yielded a cache of garments and shoes that reveal much not only about manufacturing techniques and changing fashions but about the physiques, ailments, and ambulatory mannerisms of late medieval townsfolk..$^{29}$ One unpretentious late-fourteenth century shoe displays heavy wear on the inner surfaces of the sole and some loosening of the stitching on the corresponding part of the vamp, revealing that its wearer walked with a pigeon-toed gait; extra stitching added around the outer side helped the shoe recover its symmetry. ${ }^{30}$ Its wearer was hardly a fashion victim, but the same cannot be said of the folks who squeezed their feet into the pointed shoes that became all the rage beginning in the $1370 \mathrm{~s} .{ }^{31}$ To retain the shape of these shoes the leather had to be quite stiff, and it is no wonder that people who wore them daily developed all kinds of problems, as we can see in Figure 12.3. ${ }^{32}$ Bunions, arthritis, hammer-toe - such painful ailments were both caused and exacerbated by the shoes, affecting the shape of the sufferer's feet, the way they hit the ground, and, we can surmise, the configuration of his bodily posture as he moved along the streets. ${ }^{33}$ Such a person could strike back at these agents of his discomfort, slicing the leather where her joints swelled or her toes curled to give her feet some relief. ${ }^{34}$ It is difficult to think of a more intimate confrontation of persons and things, each an active agent in giving shape and expression to the other. Ordinary people from the Middle Ages seldom recorded their mundane experiences in writing, but their shoes testify powerfully to their vanity, their pains, their yearning for comfort - their erstwhile bodily presence traversing the ground. ${ }^{35}$ I ask readers to hold all this in mind as we return to the duchess Hedwig and her material world. 
146 Hallux valgus ('bunion'). The severe patch of wear on this narrow pointed shoe is at just the point where the metatarso-phalangeal joint may be expected to swell and bulge outwards if the wearer suffers from this condition. The great toe inevitably becomes twisted in the direction of the other toes. Late 14 th-century.
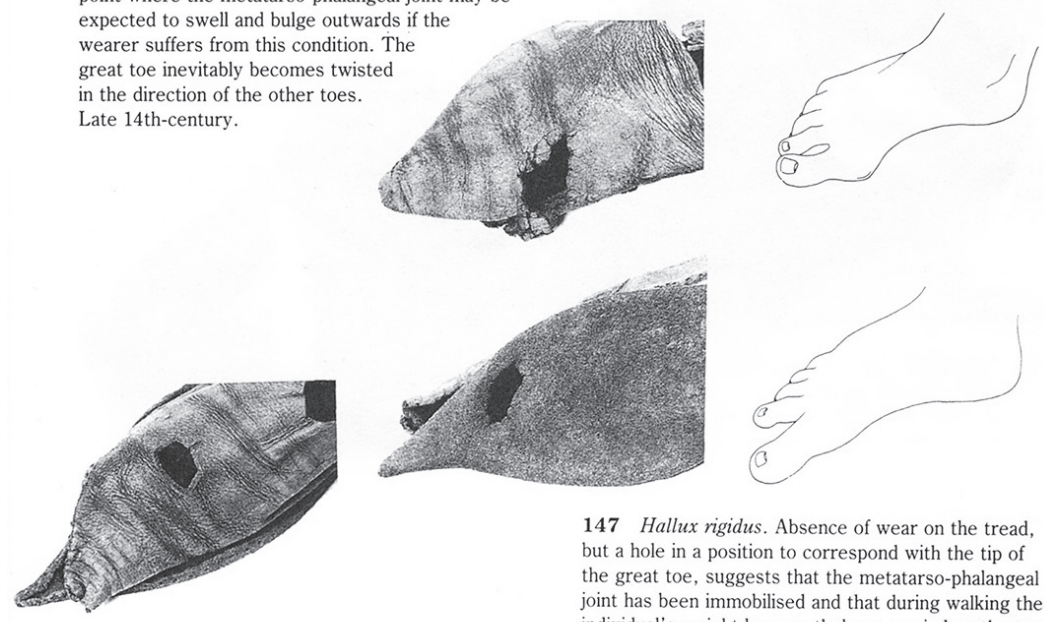

147 Hallux rigidus. Absence of wear on the tread, but a hole in a position to correspond with the tip of the great toe, suggests that the metatarso-phalangeal joint has been immobilised and that during walking the individual's weight has mostly been carried on the toe itself rather than on the ball of the foot. The cut-out in the upper was probably made to accommodate a swelling above the arthritic joint. Late 14th-century.
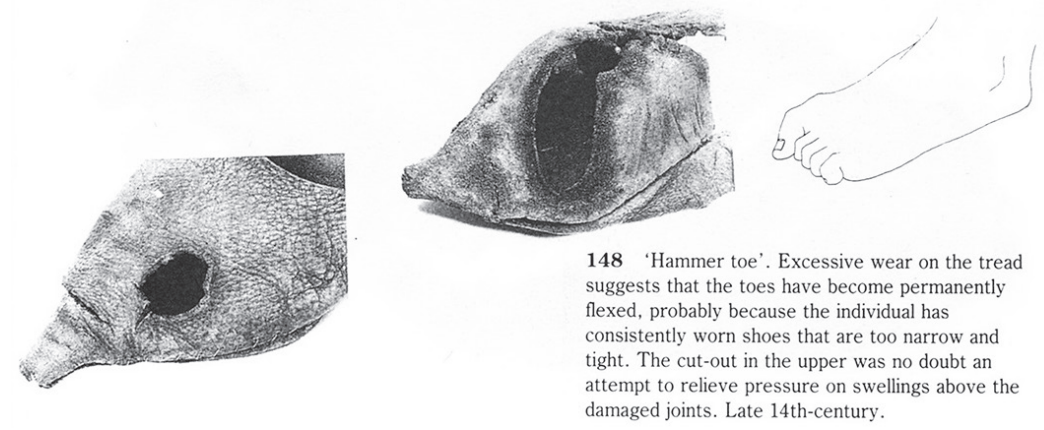

Figure 12.3 Three medieval shoes and the problems they caused to feet. Photo from: Francis Grew and Margrethe de Neergaard, Shoes and Pattens. Medieval Finds from Excavations in London: 2, rev. edn (Woodbridge: Boydell, 2001), 109.

\section{St Hedwig, Material Things, and the 'Fascinating Presence of Absences'}

It is important to keep in mind too that neither the text of Hedwig's life (the Vita Maior) nor its attendant images present an unmediated view of their subject. Though based in part on eyewitness reports, the Vita was not composed until around 1300, nearly sixty years after her death, and was made to conform in many respects to the expectations about holy women that had accrued in the intervening decades. ${ }^{36}$ The Hedwig Codex was created in 1353 at the behest of Hedwig's descendant Ludwig I, duke of Liegnitz and Brieg. ${ }^{37}$ The images, newly invented for this manuscript by a 
single artist working in dark ink with soft washes of color, are thus remarkable documents not so much of Hedwig's life as of its interpretive reception; we see here the way a particularly thoughtful ymagier, working closely with the scribe and his aristocratic patrons, sought to define the virtues of his subject. ${ }^{38}$ Subsequent artists who commemorate Hedwig in more public images (for example, a painted altar wing from Wrocław now in the National Museum in Warsaw) would retain the basic contours of these miniatures' iconography while transforming their details, muting the illuminator's subtle reflections offered on the agency of people in relation to things. ${ }^{39}$

Hedwig was born in 1174 into a family, led by the Duke of Andechs Berthold IV and his second wife Agnes of Wettin, that enjoyed a jaw-dropping level of wealth, prestige, and cultural influence. ${ }^{40}$ Her brother Eckbert was the bishop of Bamberg; her elder sister Agnes wed King Philip Augustus of France and bore him a son; her younger sister Gertrude was the wife of King Andrew of Hungary, with whom she had a daughter, the future Saint Elizabeth. ${ }^{41}$ Like her sisters and, eventually, her charismatic niece, Hedwig married an illustrious man, Duke Henry the Bearded of Silesia, and bore him seven children before insisting on a formal vow of chastity. ${ }^{42}$ From that point until his death in 1238, the Vita tells us, Hedwig interacted with her husband voluntarily only when she wanted to promote the needs of the poor or the monastic communities she supported. ${ }^{43}$ Because women could not officially establish religious institutions, Hedwig needed Henry's assistance in 1203 to found what would become her most prized community, the Cistercian convent at Trzebnica, which she initially staffed with nuns from Bamberg. ${ }^{44}$ She herself never took Holy Orders, but was a regular visitor at the convent while remaining active in the public sphere both before and after her husband's death in 1238, engaging with the needy in various ways: in the text and images of the Codex we find her feeding, washing, and giving money to the poor, sending candles to prisoners, and gaining people's release from capital punishment. ${ }^{45}$

Illustrating one of these episodes, an image on the upper half of fol. $64 \mathrm{v}$ shows a disheveled criminal being cut down from the gallows and falling to his knees before Hedwig, whose pleas for mercy have softened her husband's judgment (Figure 12.4 top). The grateful man's kneeling posture, uplifted hands, and rightward orientation find echoes in a figure in the page's lower register - this time a female derelict whom Hedwig saves from a different crippling fate (Figure 12.4, bottom). This local woman, named Quirna, has found herself unable to release the rod she was using to drive her husband's mill on a Sunday. The miller having trimmed the rod down to portable size, he has led his hapless wife, her fingers wrapped tight around it, to Hedwig. The duchess's prayers, along with the offender's promise never again to break the Sabbath laws, succeed in loosening her cramped hands. The episode is comical and overtly didactic, but the image of the woman clasping the stick resonates powerfully in this manuscript, for it forms a foil to images of Hedwig herself clutching an ivory statuette of the Madonna and Child both during her life and after her death (see Figures 12.1, 12.12, $12.14,12.15)$. We shall return to this point. For now, let us stick with the highly material, body-oriented brand of piety that this motif epitomizes.

In the private sphere of the convent at Trzebnica, this piety took many forms. It could involve works of art, as when Hedwig prayed before a crucifix and summoned it to life. ${ }^{46}$ In the illustration on fol. $24 \mathrm{v}$, the painter emphasizes the immediacy of Hedwig's engagement with Christ in the object (Figure 12.5 top). The text tells us that her custom was to pray prostrate on the floor of the convent choir; as she did 


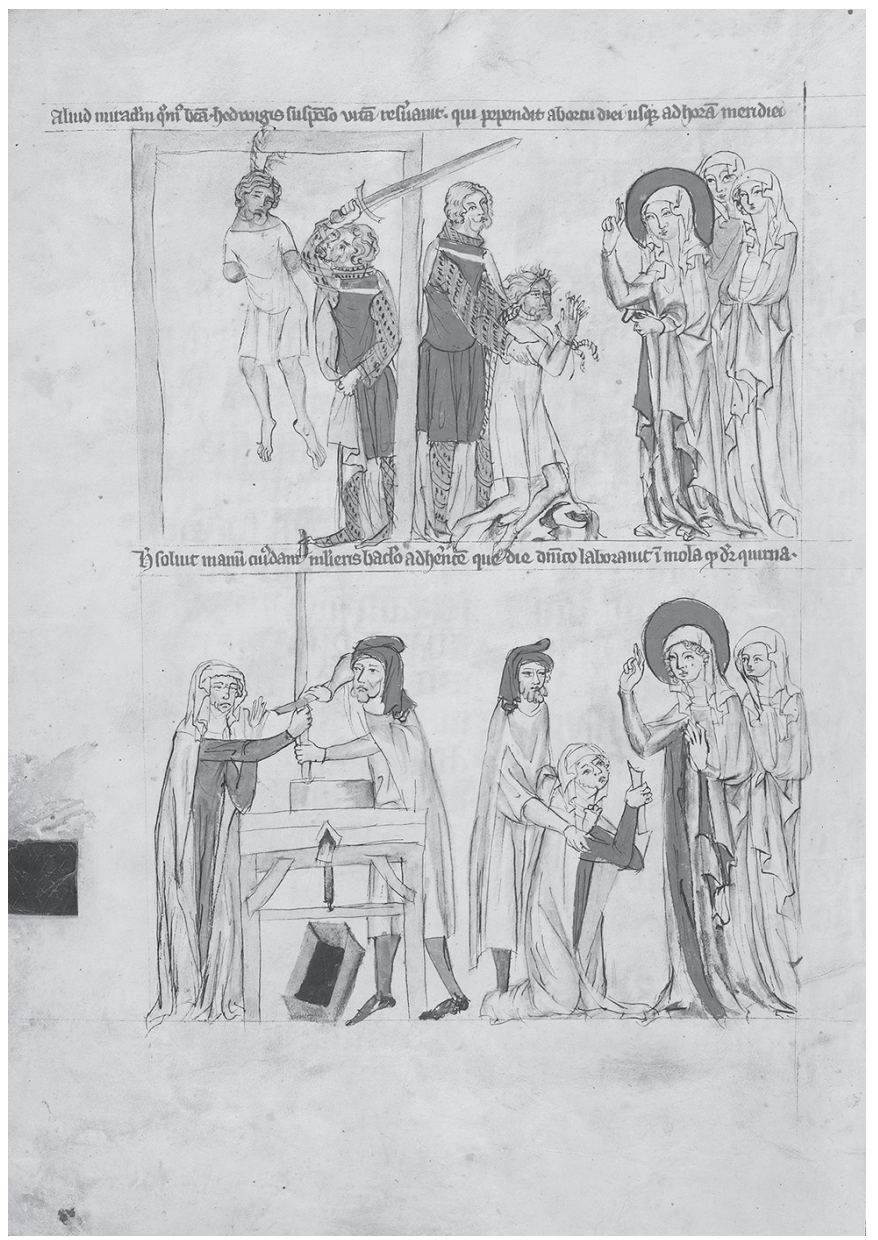

Figure 12.4 Hedwig Codex, Silesia, 1353, fol. 64v: A hanged man is released thanks to Hedwig's intervention (top); a woman who has worked a mill on a Sunday appeals to Hedwig to loosen her hands from her tool (bottom). Los Angeles, J. Paul Getty Museum, Ludwig XI 7.

so, another nun saw the crucifix remove his right hand from the cross to bless the saint, and heard him assure Hedwig that he would grant her request. ${ }^{47}$ But although in the picture the second nun retains her place as an onlooker and authenticator of the vision, the artist has transformed the scene into an intimate and direct visual dialogue: Christ, the active agent, addresses the petitioning saint, who in turn kneels upright and gazes forthrightly into his face. Blood spurts from his side wound and trickles over his ribs - red pigment flicked onto the vellum in a manner similar to its application in the scene of Hedwig's own bodily mortifications (Figure 12.6 bottom). Here we find the saint, with her crimson-lined cloak still wrapped around her hips, performing her weekly ritual of first flagellating herself and then, exhausted, forcing her reluctant maidservant Demundis to continue the work. ${ }^{48}$ The women who took up the flail after Hedwig's exertions tended to notice that drops of blood still clung 


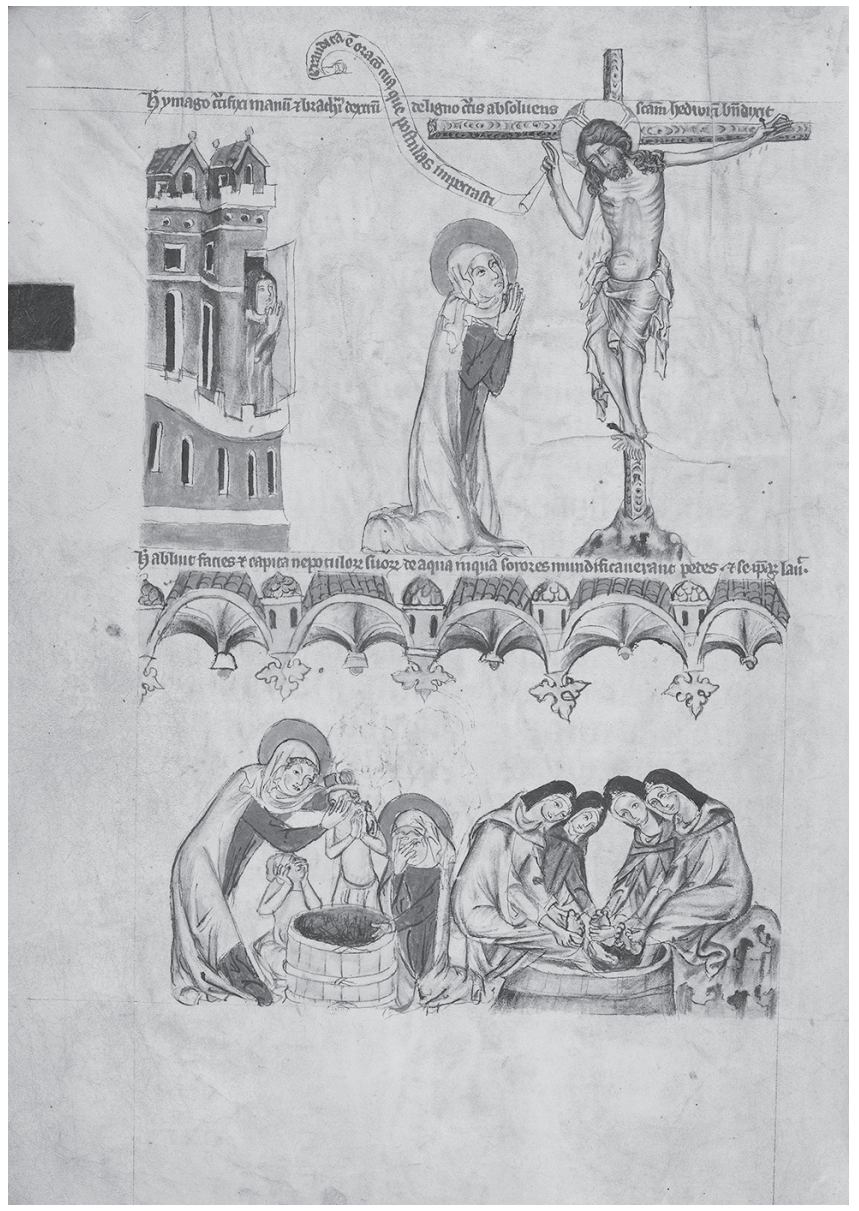

Figure 12.5 Hedwig Codex, Silesia, 1353, fol. 24v: A crucifix speaks to Hedwig during prayer (top); Hedwig cleanses herself and her grandchildren with the water nuns used to wash their feet (bottom). Los Angeles, J. Paul Getty Museum, Ludwig XI 7.

to the leather. ${ }^{49}$ The flail, as a material object, helped Hedwig refashion her flesh into something resembling the suffering Christ's - and told the tale of her efforts to those who examined it afterward. ${ }^{50}$

There were of course gentler ways of changing one's body into an image. At the top of fol. 46r Hedwig sits at her private table at the convent, taking a modest meal while a nun reads scripture aloud (Figure 12.7 top). Flanked by embodiments of activity (the singing sister) and temporary idleness (the nun at the left who waits), Hedwig freezes in mid-motion: so great is her attention to the holy words that her hand, holding a morsel of food, halts before reaching her mouth and she sits there stiffly, like a statue or painted icon. ${ }^{51}$ The episode pictured immediately below moves us from the mundane to the sublime (Figure 12.7 bottom). Rapt in solitary prayer, the saint was once suddenly encompassed by a light of indescribable radiance and intensity. The spectacle was so shocking, the text informs us, that the sole witness to 


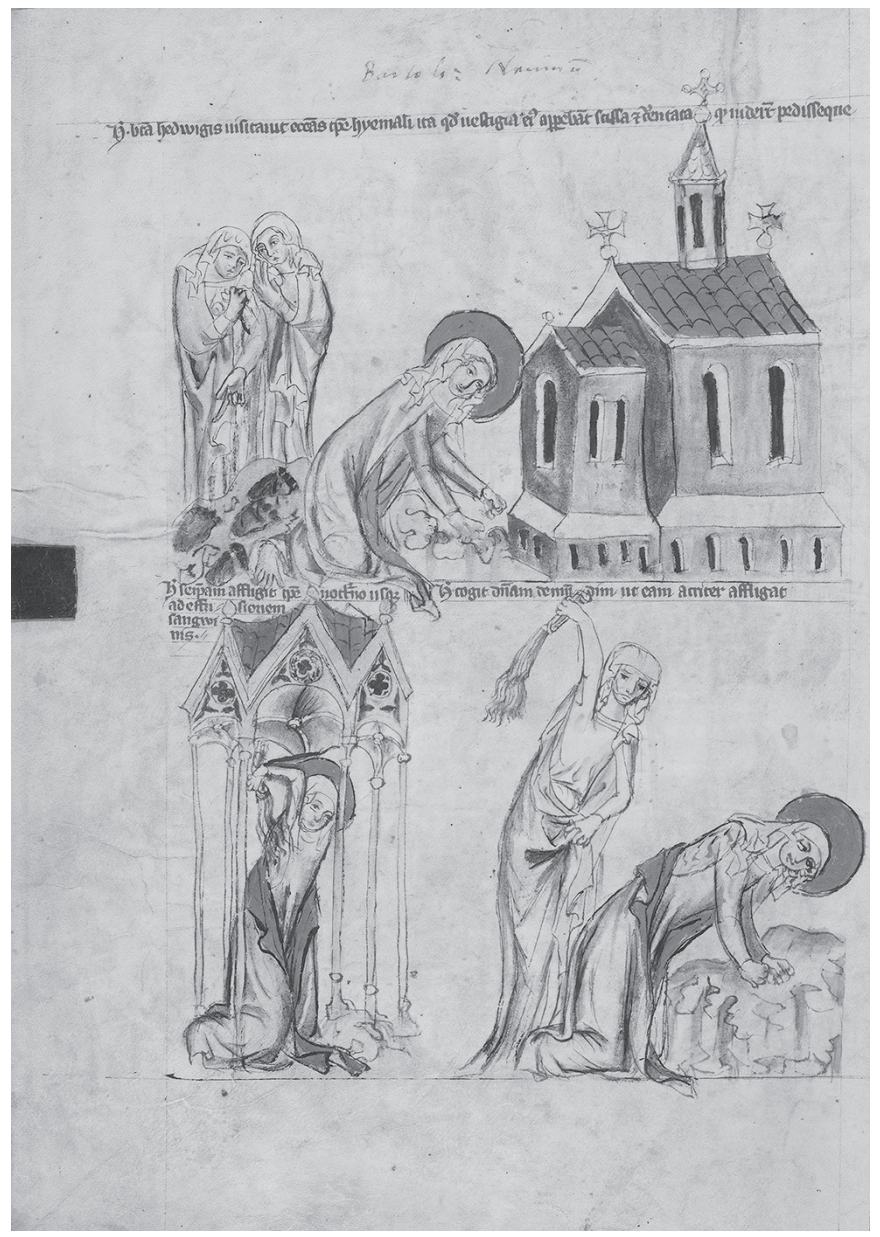

Figure 12.6 Hedwig Codex, Silesia, 1353, fol. 38v: Hedwig crawls barefoot to church through the snow, leaving bloody footprints behind (top); Hedwig flagellates herself, then has an attendant continue the process (bottom). Los Angeles, J. Paul Getty Museum, Ludwig XI 7.

the event, a veteran servant named Bogoslaus, left the house in terror. ${ }^{52}$ The rubric near his head underscores this response, stating that Boguzlaus de Savon pavore territus recessit, but the picture again tells a different story. The old man appears to be lunging into the room through an arched window as if drawn by the saint's magnetic presence, with face raised and eyes wide open. Hedwig, her back turned to him, peers through a square aperture toward the ineffable divine; the subject of her vision, somewhere beyond this architectural threshold in the blank margin of the page, remains out of our view.

Here and throughout the manuscript, Hedwig herself - both her body as object and the actions it performs - is the agent of her own contact with God and the sign to others of her special favors from him. Very often she is shown acting alone and observed 


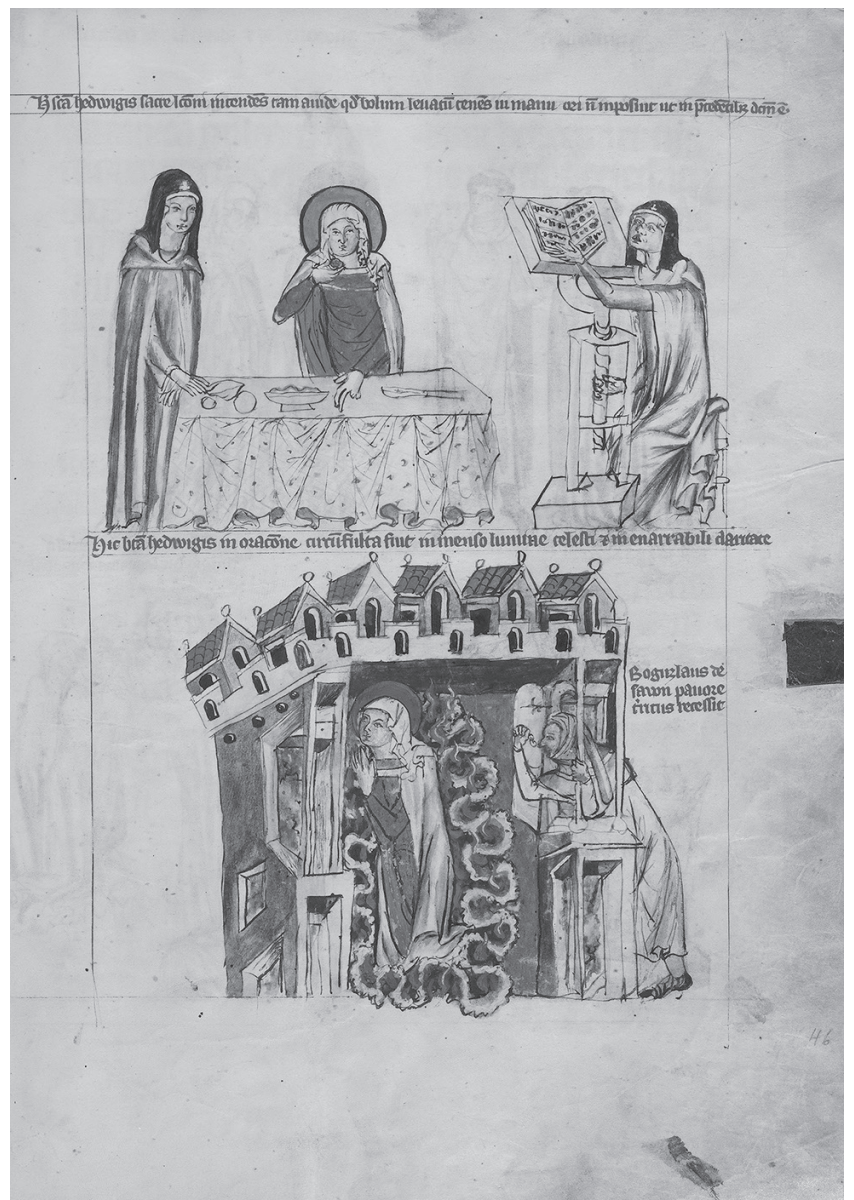

Figure 12.7 Hedwig Codex, Silesia, 1353, fol. 46r: Hedwig's hand freezes in place as she listens to scripture during dinner (top); Hedwig levitates and glows while she prays (bottom). Los Angeles, J. Paul Getty Museum, Ludwig XI 7.

surreptitiously by witnesses in the margins, who, we must assume, are the sources of information that comprised the Vita. ${ }^{53}$ When Hedwig performs devotions centered on other people, by contrast, she waits until they are gone. For example, the Vita tells us that when the sisters of Trzebnica gathered for dinner table, she would slip into the choir of their church and kiss the individual nuns' stalls (Figure 12.8 top). ${ }^{54}$ The artist renders this space ambiguous, positioning Hedwig's legs in such a way as to occlude a view of the wooden dividers between the two seats, yet nesting her halo directly within the arc of the niche. The niche itself, of course, is meant to embrace individual bodies from behind, not to canopy their heads. ${ }^{55}$ Framed by this opening, Hedwig fuses with the object: she solidifies into the furniture while animating it through her own presence, highlighting its inherent anthropomorphism. Juxtaposed with Hedwig's physical form, the abstract opening of the right-hand niche resolves into the shape of a nun's 


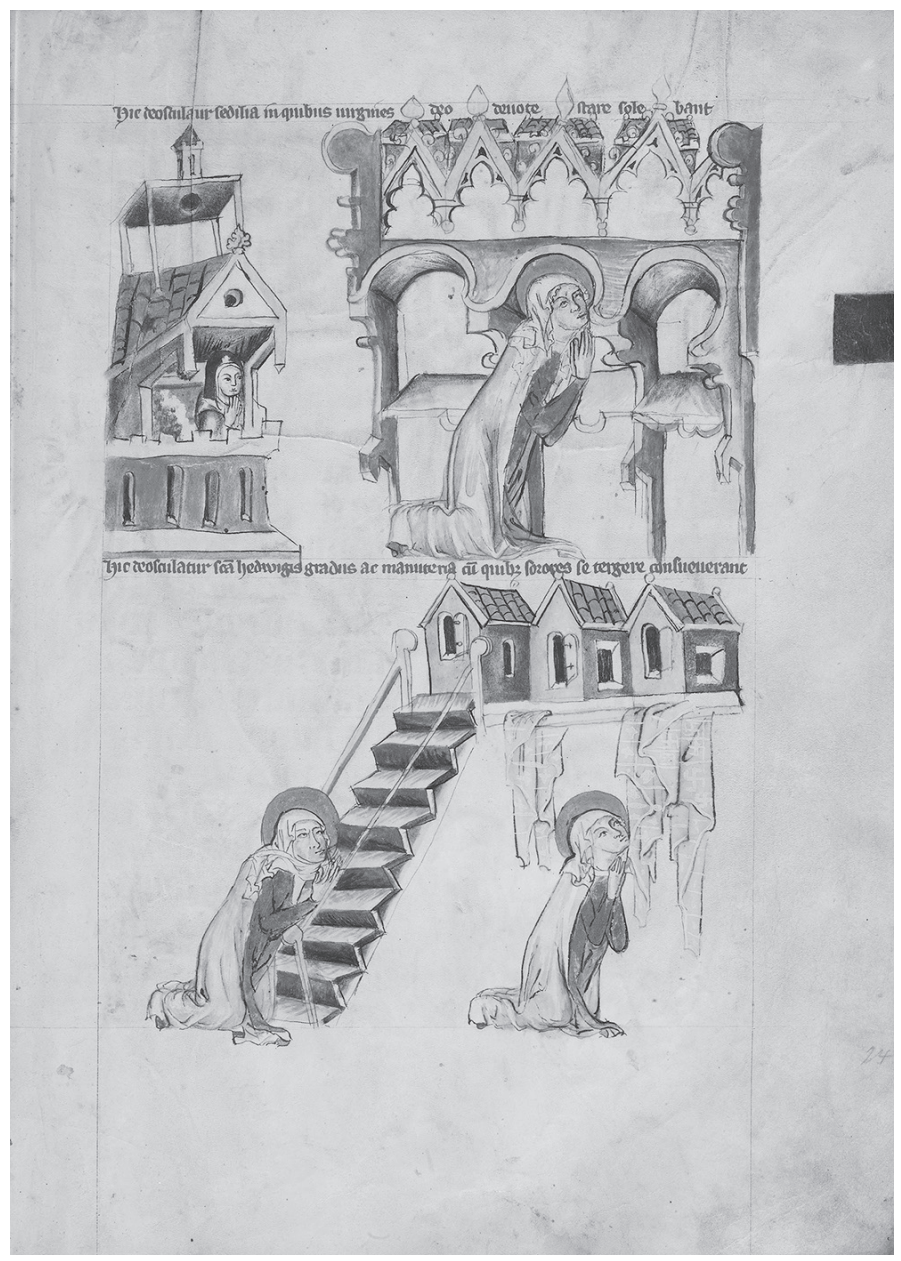

Figure 12.8 Hedwig Codex, Silesia, 1353, fol. 24r: Hedwig kisses the nuns' choir stalls in the Trzebnica convent (top), kisses the stairs to their dormitories and their used hand-towels (bottom). Los Angeles, J. Paul Getty Museum, Ludwig XI 7.

veiled head: it echoes the observing sister's contours, but with the head now tilted forward as if bowed in prayer. This reminds us, very subtly, that Hedwig's devotion is not to the choir stalls but to the women they held. The thing is important insofar as it contained the nuns' bodies, and in that respect it is never really empty. For viewers like St Hedwig, with 'imagination enough to see them,' the stalls always reverberated with the fascinating presence of their living occupants.

When the women were in choir, Hedwig discovered their presence in other places, lingering in other things. 'She would go up into their dormitory,' the text tells us, 'and humbly and devoutly kiss all the stairs that the nuns trod, and even the footstools by their beds and the switches with which they beat themselves. ${ }^{956}$ The artist here could have composed a nice vignette of Hedwig in their sleeping quarters, but chose instead to single out the objects that most powerfully oscillated between absence and presence 
(fol. 24r; Figure 12.8, bottom left). Look at the remarkable staircase she kisses. The zigzagging line of the steps' outer boundary, with its alternating pattern of grey and white, and the stark contrasts of illumination and shading on the steps themselves give this structure an extraordinary sense of volumetric presence. The solidity of its spatial construction is no less palpable than that of the little row of cells, with their steeply pitched roofs, to which it leads. The artist is intent on letting us know that Hedwig is indeed kissing the stairs: look how he has sketched the corner of one step over her halo, as if the thing were leaping up to touch her mouth. But it is not the stairs as such that merit her loving engagement; it is the women who daily traversed them.

The accordion-like folds of the stairs slicing across the folio's lower quadrant give the surrounding blank surface a remarkable palpability and spaciousness. In both its formal composition and its vacillation between surface and space, presence and absence, the structure finds a surprising resonance with the work of Rachel Whiteread, particularly her Untitled (Stairs) of 2001 at the Tate Modern in London or her Untitled (Domestic) of 2002 in the Albright-Knox Art Gallery in Buffalo. But Whiteread's casts of the spaces once defined by objects or architecture have an unsettling tendency to stimulate the viewer's wish to engage with a recognizable space and then block it off, frustrating both the viewer's imaginative entry and her ability to envision others occupying the space. ${ }^{57}$ The artist of the Hedwig Codex, by contrast, uses objects like the staircase to open up the field of imaginative projection for both his protagonist and beholders.

The image's suggestive capacity extends into the adjacent vignette (Figure 12.8, bottom right), where we witness Hedwig in the nuns' living quarters, kissing the towels with which they have washed their hands 'in enormous love and virtuous humility particularly in the places where they showed the most dirt. ${ }^{98}$ Although the text proceeds to describe her 'making the sign of the cross on her eyes and breast with these unclean cloths, as if they were holy relics,' the painter shows no tactile engagement, placing Hedwig instead in the empty space between the towels. This leaves viewers to imagine her manipulating the cloths that she sees as still infused with the holy presence of the unseen nuns. By imagining her fondling the clothes, we perform the same kind of projection of people onto objects that Hedwig does when she treats those objects as sacred. In this light it is tempting to read the sketchy patterns of crosses and hooked crosses, painted in vivid white against the creamy wash of the cloths, not as embroidered designs but as visible traces of Hedwig's gestures. By treating these ordinary hand-towels 'as if they were holy relics,' she made them into holy relics. Here again, the focus of both text and image is not on the sanctity of the sisters or the special quality of their material environment. What is special is Hedwig's devotion to the women through the things they touched - the rich imagination that, like Hardy's cobbler's, enabled her to find the sparkling human presence in the stuff of daily life.

Sometimes that presence was not so sparkling, as when Hedwig used the dirty water in which the nuns had washed their feet to cleanse 'her own eyes and face'; indeed, we learn, she would wash 'her whole head and neck' in that water, as well as the faces of her 'little grandchildren,' born aristocrats all (Figure 12.5). ${ }^{59}$ This was a thing 'to be marveled at' (mirandum est); medieval readers were clearly not expected to think that the dirt from monastic women's feet was something to be sought out. In this image the artist has rendered palpable the material substance of the dirt by scribbling deep lines within the murky gray wash that fills the tub - lines that suggest not only the filth of the nuns' feet but also the vital, active presence of the draftsman's hand. 


\section{The Boots of Saint Hedwig}

No dirt appears on these figures' faces, but Hedwig was known to leave traces of her own body for others to see and marvel at: footprints laced with blood that clung to rocks and dirt and snow as she made her way, often tired and weakened by fasting, from her home to various churches in the area between Wrocław and Trzebnica (Figure 12.6 top). Her own feet, the Vita tells us, were seldom washed. 'Their soles were raw and hard and had many large cracks, into which one could fit a twig (festuca) or even a finger.' ${ }^{60}$ They bled frequently, not only when she was trudging through the cold but also when she was resting at home, though she seldom seemed to notice or to be bothered by it herself. ${ }^{61}$ Why did Hedwig have such foot problems? Because, as you have undoubtedly predicted, she did not wear shoes.

This was evidently a huge deal. We must remember that Hedwig was about six years older than Francis of Assisi, whose followers would make bare feet an emblem of their brand of urban religiosity. ${ }^{62}$ During her lifetime, going barefoot outdoors was hardly commonplace - especially in northern Europe, especially for people of high status, and especially for women. ${ }^{63}$ Even in the fourteenth century, the bare feet she displays in the full-page miniature and elsewhere in the manuscript would have looked as strange and incongruous as those sported in public by particularly daring or drunken celebrities. ${ }^{64}$ In the Hedwig Codex, nine columns of text over six folio surfaces (fols. 34v-37) detail the duchess's refusal to wear shoes, the resulting damage to her feet, and the conflicts this form of asceticism caused with the people who cared about her. ${ }^{65}$ One can sympathize with her husband, Duke Henry, who insisted (surely for symbolic as well as practical reasons) that she put shoes on and grew angry when she did not. One day, in a miracle highlighted by a manicule in the codex's margin (fol. 35), her husband made a surprise visit to her quarters. ${ }^{66}$ Mirabile dictu, God, 'the one for whose sake she kept her feet bare,' instantly made shoes appear on her feet so that she would escape his indignation (Figure 12.9 top).

Normally Hedwig kept what the text calls 'shoes' (calciata) tucked under her arm. Both the full-page image and the narrative vignettes that portray her rejection of footwear, by contrast, show tall, soft boots slung over her arm (Figures 12.1, 12.9). This is a bit of artistic license that makes them more visible, but it may also have had social resonance. In the mid-fourteenth century, such boots were seriously out of fashion. Even in monastic communities, evidence survives of people rejecting the leather boots they were allotted in favor of low-cut, lightweight shoes with pointed toes (much to the chagrin of authorities). ${ }^{67}$ The very fact that Hedwig carries boots, and not the pointed shoes that her husband and his retinue wear, is already a sign of her selfimposed austerity.

In any case, in both text and image, not only her bare feet but also the unworn boots became a visual hallmark of Hedwig's sanctity- and the impetus of her best joke in the Vita.

One of her confessors, an abbot Gunther of Leubus, once gave her a pair of new shoes and ordered her to wear them. She accepted them gladly, but instead of wearing them, carried them around under her arm. After a year, the abbot reprimanded her for her disobedience, whereupon she showed him the shoes, just as new and unused as when she had gotten them, and said humbly [with a play on the fact that the Latin word portare, like the German tragen, means both 'to wear' and 'to carry']: 'My father, I was indeed obedient; here are the shoes you gave me, and I have carried/worn them often [et ego eos frequenter portavi]. ${ }^{96}$ 


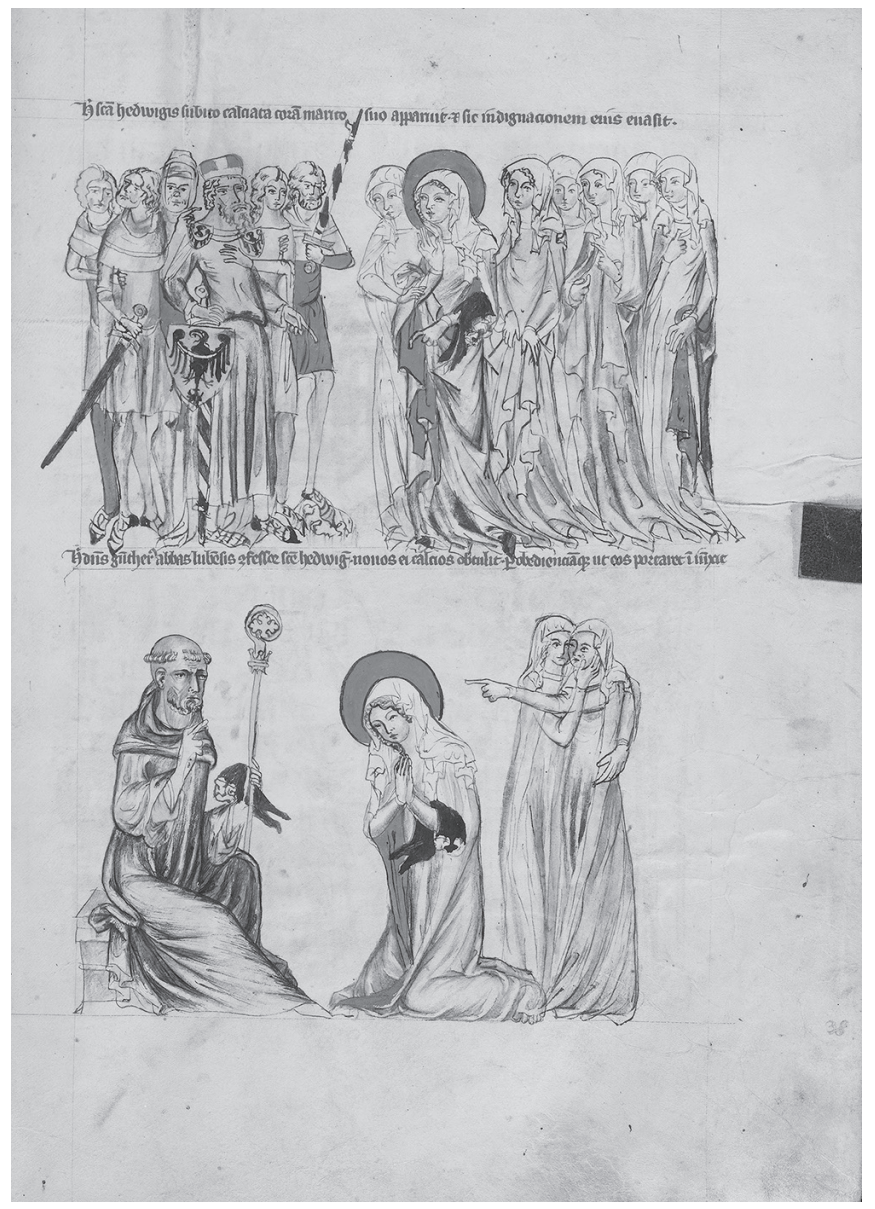

Figure 12.9 Hedwig Codex, Silesia, 1353, fol. 38r: Hedwig's normally bare feet are miraculously shod when her husband surprises her in her chamber (top); Hedwig demonstrates to her confessor how she has 'worn' the shoes he gave her (bottom). Los Angeles, J. Paul Getty Museum, Ludwig XI 7.

This confrontation is what we see at the bottom of fol. 38r (Figure 12.9), but here the merriment is transferred onto Hedwig's two attendants, who huddle together in the corner and point sassily toward the stern abbot, while the saint kneels in feigned innocence.

When our artist included these boots among Hedwig's devotional accessories in the showstopping full-page image (Figure 12.1), then, it was not because of any special material properties they possessed. It was not even because they were relics that bore the imprint of a body's encounters with the world, like Van Gogh's shoes or Hardy's dainty boot or the slashed-up shoes of hammer-toed townspeople (Figures 12.2, 12.3). It was because she carried them. Otherwise devoid of her presence, the boots served to index her attitude and her actions - her strong-willed behavior toward male authorities, her circumvention of noble decorum, her cheeky wit, her willingness to wreck her 


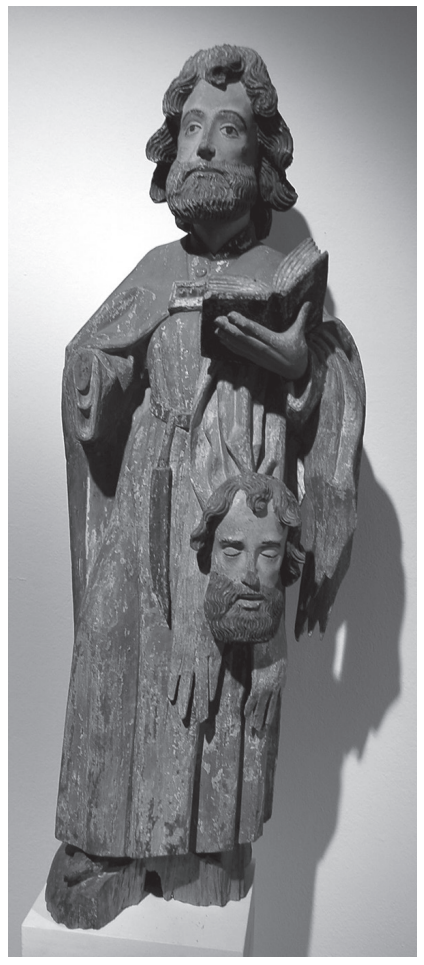

Figure 12.10 Sculpture of St Bartholomew, wood with polychromy, southern Germany or Switzerland, c.1470. Fribourg (Switzerland), Musée d'art et d'histoire.

feet, just as she wracked her flesh, for God. As things, the boots are just dead weight scraps of once-living flesh no more useful, in themselves, than the flayed skin that St Bartholomew holds in so much late medieval devotional imagery (Figure 12.10). ${ }^{69}$

Willful as it might seem, the comparison between Hedwig's empty boots and Bartholomew's flaccid flesh is appropriate not only because both are devoid of life; Bartholomew also happened to be the patron saint of the Trzebnica convent and of the Piasts, the Silesian clan into which Hedwig had married. ${ }^{70}$ As such he appears in the Hedwig Codex, along with St Vincent, as a sculpture on the main altar of the convent church (Figure 12.11, bottom left). It is at this point in the visual narrative that we first see the ivory statuette that the duchess was also known to carry around. Interestingly, the page showing Hedwig's shoe controversies (fol. 38r, Figure 12.9) and that showing her praying at the altar are composed similarly (fol. 46v, Figure 12.11). In the upper register of each, Hedwig, standing with her attendants, confronts a male authority figure across a blank space: in the former page it is her husband demanding that she wear shoes, and in the latter her chaplain, who introduces a layman disguised as a priest who will read her the mass. In each lower register, the duchess kneels and makes gestures of prayer. In the one case she faces her confessor, who bears an empty boot curled around his staff; in the other she faces her church's sacred patrons, one of whom bears his old flesh on a rod balanced on his shoulder like a grisly bindle. And in the one case Hedwig lets her own boots droop over her arm - dead, useless items - while in the other she 


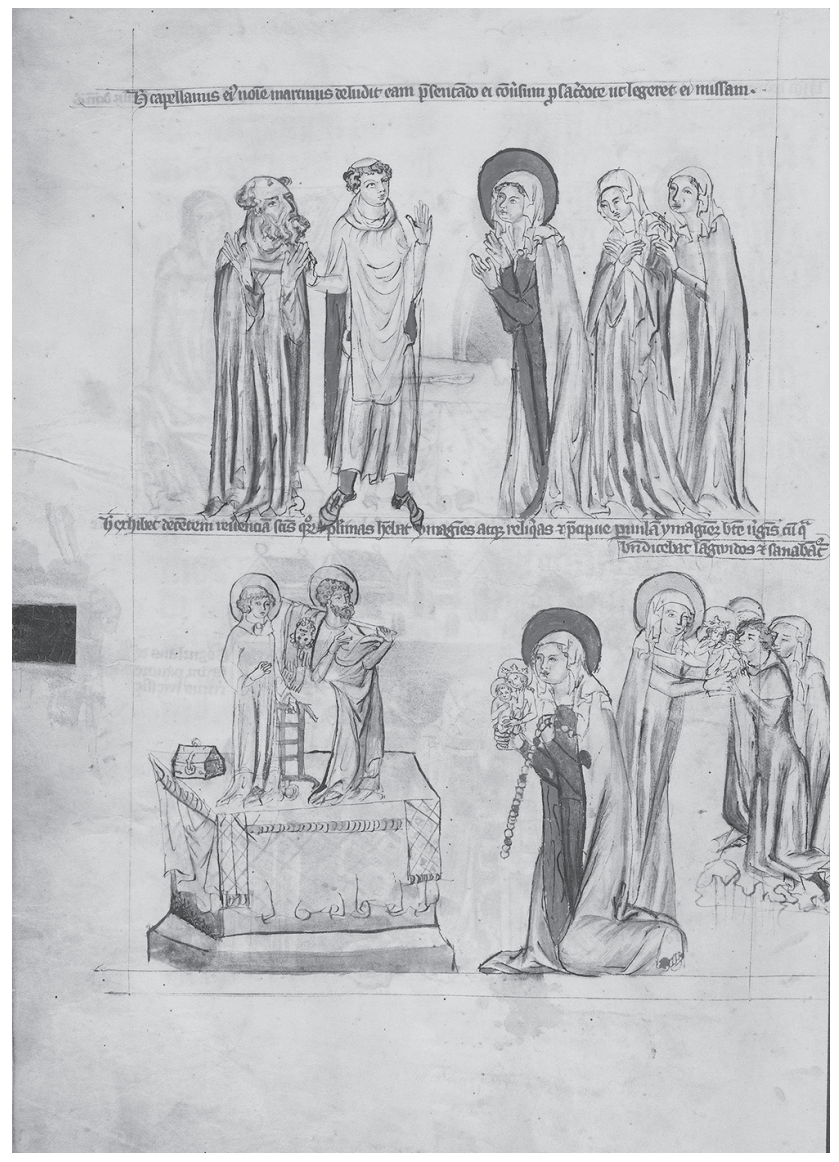

Figure 12.11 Hedwig Codex, Silesia, 1353, fol. 46v: Hedwig converses with her chaplain (top); Hedwig prays at altar of Trzebnica convent church holding ivory statuette and gives the statuette to others to kiss (bottom). Los Angeles, J. Paul Getty Museum, Ludwig XI 7.

clutches to her chest both a set of rosary beads and the ivory figurines, the Holy Mother and Child, whose halos testify to their living, vibrant presence despite their status as artificial representations.

Although the statuette represented Christianity's most important characters, and although our artist has pictured them with slight shifts in position and gaze, as if they were animate beings, ${ }^{71}$ the Vita ascribes no agency to the object at all. Hedwig holds it 'in order to gaze at it lovingly,' and seeing it 'strengthens her devotion and arouses her to greater love of the glorious Virgin. ${ }^{72}$ When Hedwig holds the figure up to sick people, they are healed - not through the power of Mary, but as a sign of 'the great rewards gained by one who always carried the Mother of God with her out of the zeal of love. ${ }^{73}$ Although the illuminator did not show Hedwig holding the statuette on her deathbed at Trzebnica (fol. 82v; Figure 12.12), he did append to that scene a vignette testifying to the saint's eventual presence in absence: in a twist on Hedwig's own practices (see Figure 12.5), a sister washes her face and drinks of the water 


\section{0}

\section{The Boots of Saint Hedwig}

that had been used to clear the saint's corpse, and finds herself cured of her chronic thirst (Figure 12.12, bottom right). But the little sculpture returned, nestled against Hedwig's abdomen like an infant in the womb, when she was shown liturgically commemorated and prepared for burial (fol. 87r; Figure 12.13).

When, in the process of her canonization in 1267 , she was exhumed and her relics translated into the church, Hedwig's left hand remained intact, clutching the ivory figure as a sign of her deathless devotion. ${ }^{74}$ The statuette itself was merely a representation; its importance resided in the fact that it could be grasped. As an index and confirmation of sanctity, it was the woman's uncorrupted hand that bore the agency in this scenario, and formed the focus of devotional attention (Figure 12.14 bottom). The detached hand clasping the figurine, carried by a solemn-faced bishop, occupies a central place in the image of the official procession into church. Before him stands another cleric cradling the saint's haloed skull, preparing to follow candle-bearing deacons into the portal; behind him, another dignitary clutches more bones (including a near-intact right hand) while a passel of noble laymen wearing daggers - and, in one case, fine pointed shoes - look on mournfully. Hedwig, reduced to an assortment of

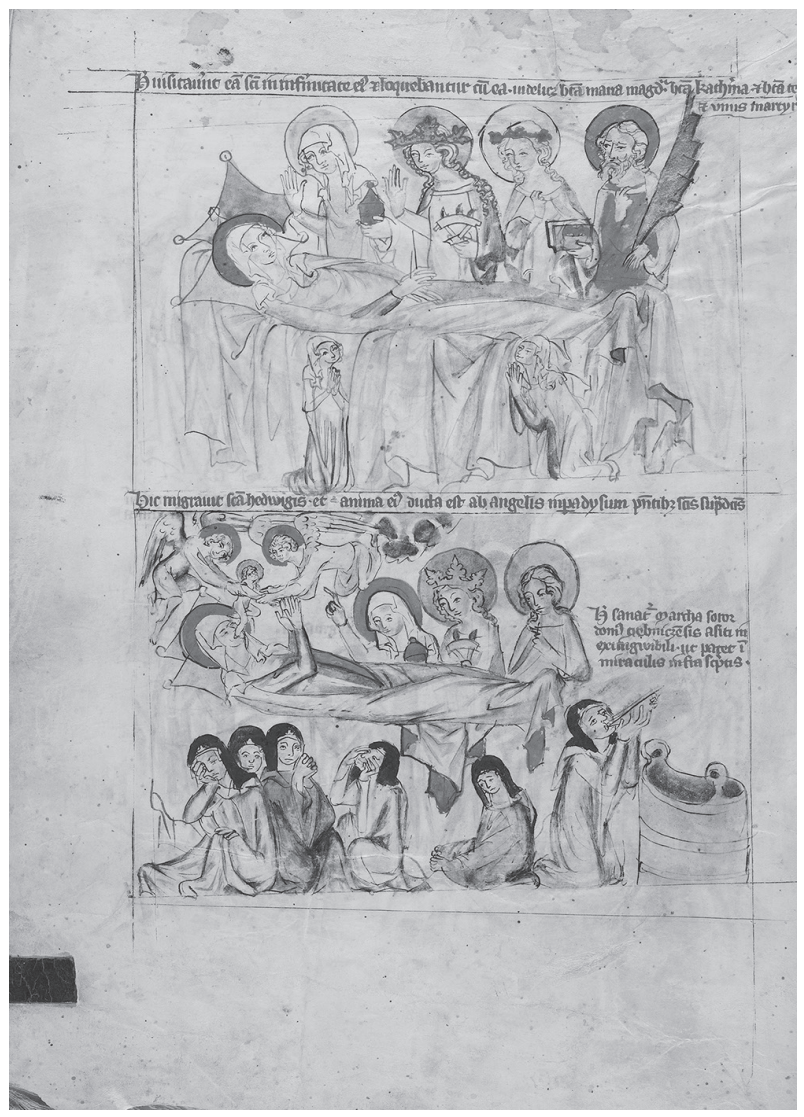

Figure 12.12 Hedwig Codex, Silesia, 1353, fol. 82v: Hedwig is attended by saints on her deathbed (top), then breathes her last in the presence of nuns (bottom). Los Angeles, J. Paul Getty Museum, Ludwig XI 7. 


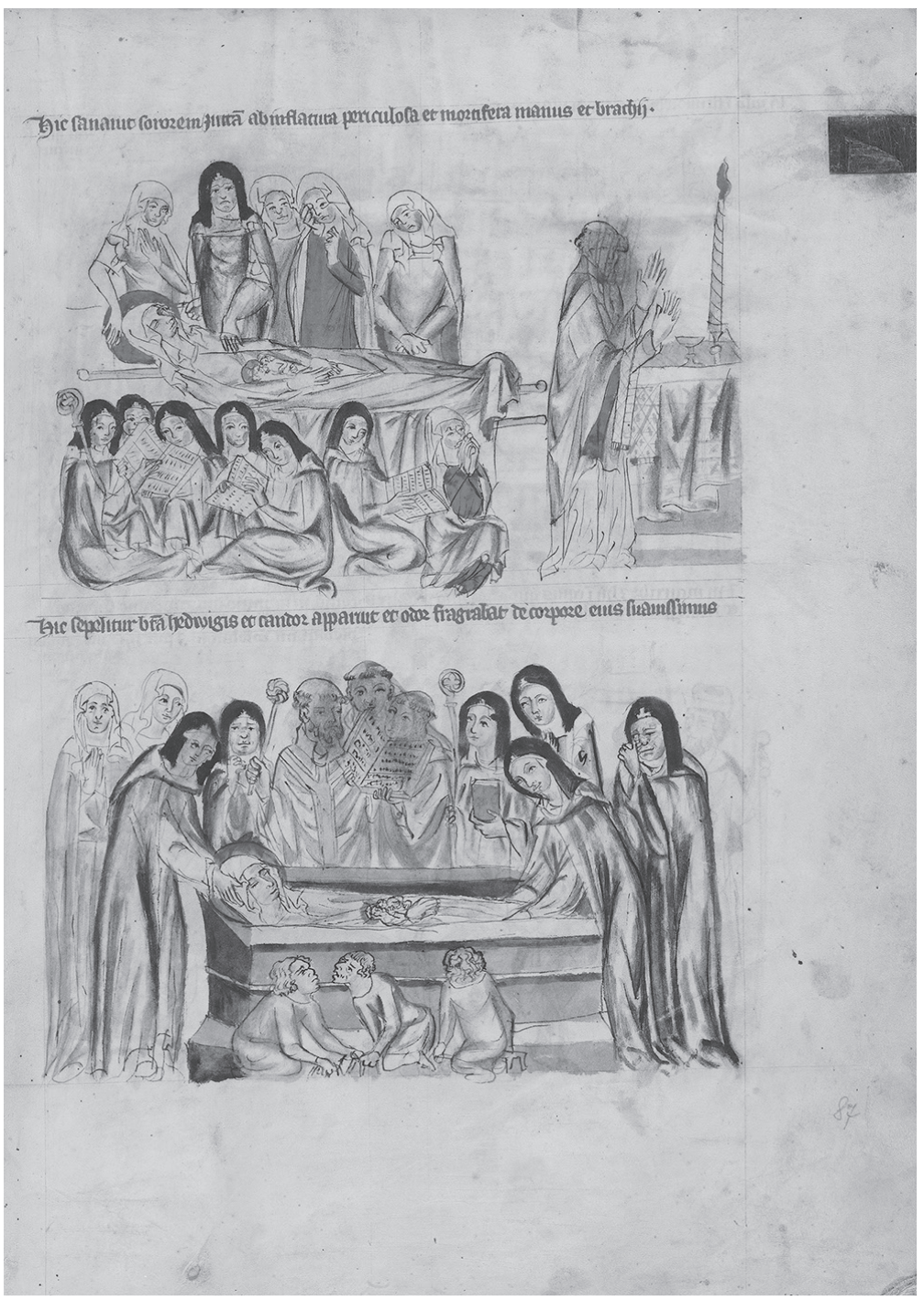

Figure 12.13 Hedwig Codex, Silesia, 1353, fol. 87r: Hedwig is liturgically commemorated (top) and prepared for burial (bottom). Los Angeles, J. Paul Getty Museum, Ludwig XI 7.

parts, has made the transition from person to thing, and we, along with the book's original readers, can rest assured that she would assume a new, enduring form of power through her relics. ${ }^{75}$

The pictorial program also includes scenes of miracles enacted near and far from her body before its translation, but I want to close with that central motif in the procession image: the man in the crowd, holding a hand that grasps a sculpture of a woman holding a child who touches her. For this little sequence of nested bodies, with the sculpted artefact at their center, stands as an inverted exemplar of the pattern we have charted 


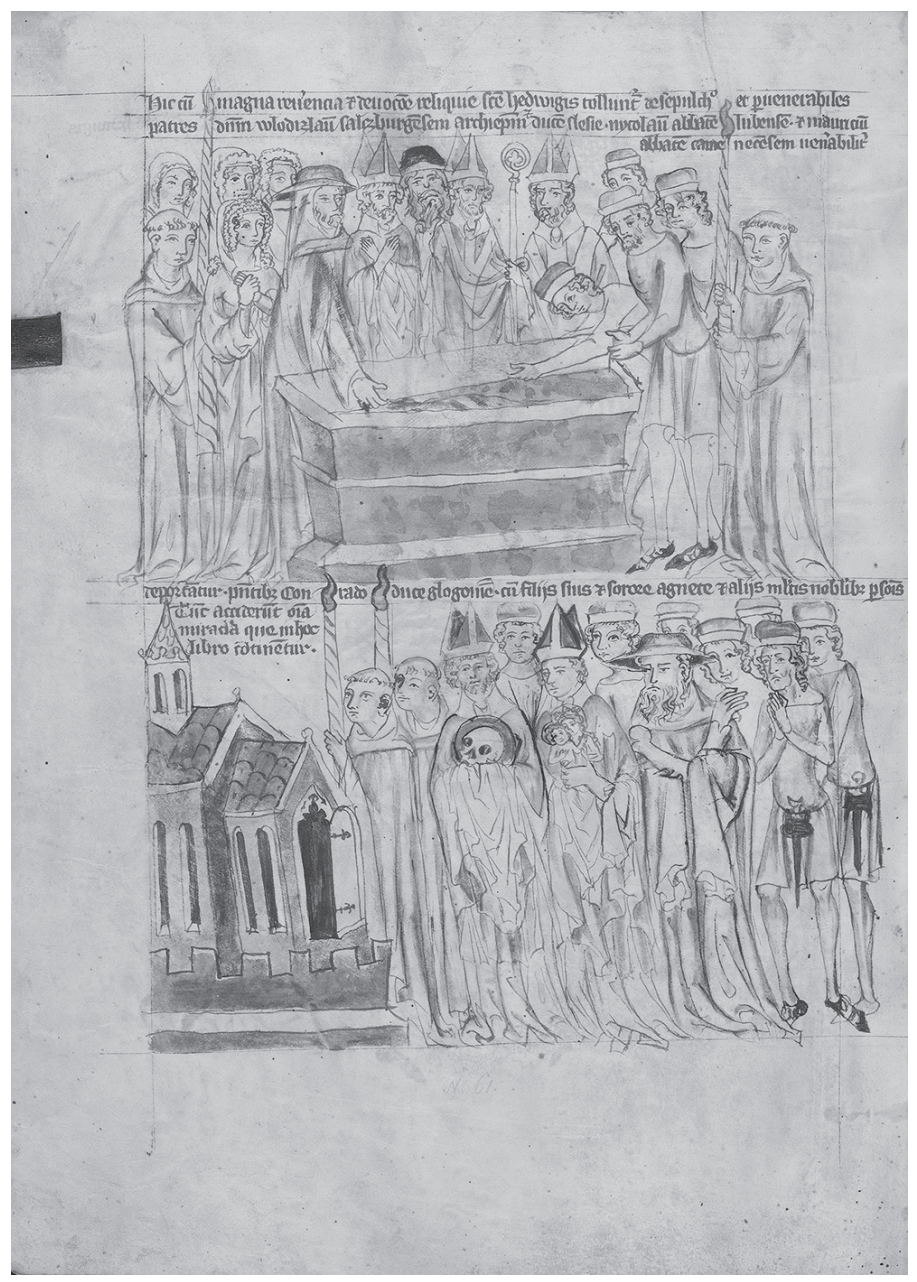

Figure 12.14 Hedwig Codex, Silesia, 1353, fol. 137v: Hedwig is exhumed (top) and her relics processed into church at her canonization in 1267 (bottom). Los Angeles, J. Paul Getty Museum, Ludwig XI 7.

throughout this manuscript - one that, in my view, is vital as we art historians reflect on our métier in the midst of the present 'material turn.' I am referring to the celebration of the human-made object (the choir-stall, the hand-cloth, the shoe, etc.) that was physically empty but nonetheless replete with the presence of the women or men who made it, touched it, inhabited it, looked at it - the human agents who gave the thing life. This model extends to the Hedwig Codex itself, whose pictures - which their sketchy outlines, thin coloration, abundant pentimenti and corrective scrapings - are so cheerfully open in their revelation of the artist's nimble hands and mind at work.

In this light, the full-page depiction of St Hedwig assumes a new aspect (Figure 12.1). With her empty boots calling attention to her bare feet, with her prayerbook and statuette evincing her own devotional agency, with her beautifully drawn body providing a model for her adoring descendants, Hedwig does not emblematize the 'agency of things' 
after all. ${ }^{76}$ Rather, she insists that we remember all those absent people - the makers, subjects, and recipients of art - whose fascinating presence we can still discern, with some imagination, in the things they left behind. ${ }^{77}$

\section{Notes}

1 A facsimile of the manuscript, now held by the Getty Research Institute in Malibu, California (MS Ludwig XI 7), has been published as Der Hedwigs-Codex von 1353. Sammlung Ludwig, ed. Wolfgang Braunfels (Berlin: Mann, 1972), hereafter cited as HC. The accompanying volume, containing a complete edition of and commentary on the texts by Peter Moraw, will be cited as HC2. High-resolution color images of all the Hedwig Codex illuminations may be viewed or downloaded through the Getty's Open Content Program: http://www.getty. edu/art/collection/objects/1407/unknown-maker-nicolaus-of-prussia-vita-beatae-hedwigissilesian-1353-000000/. I urge readers to consult these wonderful reproductions to see the smaller details I discuss below.

2 Corinne Schleif, 'St. Hedwig's Personal Ivory Madonna: Women's Agency and the Powers of Possessing Portable Figures,' in The Four Modes of Seeing: Approaches to Medieval Imagery in Honor of Madeline Harrison Caviness, eds Evelyn Staudinger Lane Elizabeth Carson Pastan, and Ellen M. Shortell (Farnham: Ashgate, 2009), 382-403; Jacqueline E. Jung, 'The Tactile and the Visionary: Notes on the Place of Sculpture in the Medieval Religious Imagination,' in Looking Beyond: Visions, Dreams, and Insights in Medieval Art and History, ed. Colum Hourihane (Princeton, NJ: Index of Christian Art, 2010), 203-40; Jeffrey F. Hamburger, 'Representations of Reading Reading Representations: The Female Reader from the Hedwig Codex to Châtillon's Léopoldine au Livre d'Heures,' in Die lesenede Frau, ed. Gabriela Signori (Wiesbaden: Harrassowitz, 2009), 183-245; and Ewald Walter, 'Hedwigs Stellung zur bildenden Kunst im Zisterzienserorden,' in Studien zum Leben der hl. Hedwig Herzogin von Schlesien (Stuttgard: Theiss, 1972), 13-35.

3 One thinks here of Gerald Waller's famous photograph of an Austrian orphan throwing his face blissfully skyward as he hugs a pair of shiny new dress shoes, first published in Life Magazine, 30 December 1946, 22. See http://blog.burnedshoes.com/post/34117773241/geraldwaller (last retrieved 25 July 2017).

4 Mildred Davison, 'Shoes of Our Ancestors', Bulletin of the Art Institute of Chicago, 28 (1934), 103-6.

5 What follows is drawn from Jacob Nacht, 'The Symbolism of the Shoe with Special Reference to Jewish Sources,' Jewish Quarterly Review, n.s. 6 (1915), 1-22.

6 Ibid., 15.

7 Livio Pestilli, 'Apostolic Bare Feet in Masaccio's Tribute Money: Early Christian and Medieval Sources,' Source: Notes in the History of Art, 26 (Fall 2006), 5-14.

8 Ibid., 9-10.

9 See Nils Holger Petersen, 'Medieval Liturgy and the Senses: The Case of the Mandatum,' in The Saturated Sensorium: Principles of Perception and Mediation in the Middle Ages, ed. Hans Henrik Lohfert Jørgensen, Henning Laugerud, and Laura Katrine Skinnebach (Aarhus: Aarhus University Press, 2015), 180-205.

10 Nacht, 'Symbolism,' 5. For a recent case, see Steven Lee Myers and Alissa J. Rubin, 'Iraqi Reporter Hurls Shoes at Bush and Denounces Him on TV as a "Dog”,' New York Times, 14 December 2008; online edition: http://www.nytimes.com/2008/12/15/world/ middleeast $/ 15$ prexy.html?pagewanted=all\&_r=0 (last retrieved 20 August 2015).

11 For a survey of shoes gleaned from archaeological and art historical records, with a focus on the northern European Middle Ages, see Olaf Goubitz et al., Stepping through Time: Archaeological Footwear from Prehistoric Times until 1800 (Zwolle: Stichting Promotie Archeologie, 2001).

12 See an altarpiece panel by one of the Bern Nelkenmeister from around 1505, now in the Schweizerisches Nationalmuseum in Zurich; reproduced in Armut: Perspektiven in Kunst und Gesellschaft, eds Herbert Uerlings et al. (Darmstadt: Primus, 2011), 181, Figure 92.

13 See Michel Mollat, The Poor in the Middle Ages: An Essay in Social History (New Haven, CT: Yale University Press, 1986), 143 and passim; Feudal Society in Medieval France: 


\section{4}

\section{The Boots of Saint Hedwig}

Documents from the County of Champagne, ed. Theodore Evergates (Philadelphia: University of Pennsylvania Press, 1993), 143-4; Christopher Daniell, Death and Burial in Medieval England, 1066-1550 (London: Routledge, 1997), 50-1.

14 See Jacqueline E. Jung, The Gothic Screen: Space, Sculpture, and Community in the Cathedrals of France and Germany, ca. 1200-1400 (Cambridge: Cambridge University Press, 2013), 139-44, with relevant bibliography.

15 Reproduced in ibid., 132.

16 Franz, Die Messe im deutschen Mittelalter (Freiburg: Herder, 1902), 226, note 1.

17 Rachel Donadio, 'Preserving the Ghastly Inventory of Auschwitz', New York Times, 15 April 2015, online edition: http://www.nytimes.com/2015/04/16/arts/international/atauschwitz-birkenau-preserving-a-site-and-a-ghastly-inventory.html?_r=0 (last accessed 24 October 2016).

18 See http://auschwitz.org/en/museum/historical-collection/, last accessed 24 October 2016.

19 The basic information comes from https://en.wikipedia.org/wiki/Shoes_on_the_Danube_ Bank (last accessed 24 October 2016).

20 Martin Heidegger, 'The Origin of the Work of Art,' in Poetry, Language, Thought, trans. Albert Hofstadter (New York: Harper \& Row, 1971), 17-87, here 33-4.

21 Meyer Schapiro, 'The Still Life as a Personal Object - A Note on Heidegger and van Gogh'(1968), repr. in Theory and Philosophy of Art: Style, Artist, and Society (New York: Braziller, 1994), 135-42.

22 Dietrich Schubert, 'Van Goghs Sinnbild 'Ein Paar alte Schuhe' von 1885, oder: ein Holzweg Heideggers,' in Habitus: Norm und Transgression in Bild und Text. Festgabe für Lieselotte E. Saurma-Jeltsch, eds Tobias Frese and Annette Hoffmann with Katharina Bull (Oldenbourg: Akademie, 2011), 331-54, here 346.

23 Quoted in ibid., 347.

24 On Hardy's materialist orientation, see Elaine Scarry, 'Work and the Body in Hardy and Other Nineteenth-Century Novelists,' in Resisting Representation (New York: Oxford University Press, 1994), 49-90.

25 Thomas Hardy, Under the Greenwood Tree (Oxford and New York: Oxford University Press 1985), 25-6.

26 Michel de Certeau, The Practice of Everyday Life, trans. Steven F. Rendall (Berkeley, CA: University of California Press, 1984), 21.

27 Ibid.

28 So do poets, novelists, and of course anthropologists, as Miri Rubin reminded us in her contribution to the Agency of Things conference; see, for example, Daniel Miller, The Comfort of Things (Cambridge: Polity Pres, 2008), and E. Annie Proulx, Accordion Crimes (New York: Scribner, 1996).

29 Francis Grew and Margrethe de Neergaard, Shoes and Pattens. Medieval Finds from Excavations in London: 2, rev. edn (Woodbridge: Boydell, 2001). For other cases see Justyna Wubs-Mrozewicz, 'Shoes and Shoemakers in Late Medieval Bergen and Stockholm,' Collegium Medievale (2005), 7-35; and Goubitz et al., Stepping through Time.

30 Grew and de Neergaard, Shoes and Pattens, 108.

31 These were known in France and England as 'poulaines' or pikes, and in Germany as 'crakower' for their supposed origins in Cracow. See ibid., 116.

$32 \mathrm{Ibid}$., 109; see, in the same book, 24, 108, and 110 for photos of other shoes that register distress.

33 See the remarks accompanying Figure 148, in ibid., 109, reproduced here as Figure 12.3.

34 Cf. a predella panel by the Master of the Rinuccini Chapel from c.1370, now at the Accademia in Florence, in which a colorfully garbed St Anthony Abbot distributes money to beggars. Their neediness is manifest not only in their stooped postures but also in their feet, which, if not bare, are shod in well-worn, sliced-up shoes.

35 As evident in the permanent display of medieval shoes at the Budapesti Történeti Múzeum (Budapest History Museum), and the Fall 2015 exhibition at the Victoria and Albert Museum, London, called 'Shoes: Pleasure and Pain'' which takes a cross-cultural approach. See http://www.vam.ac.uk/content/exhibitions/shoes-pleasure-and-pain/about-the-exhibition/ (last accessed 23 October 2016).

36 See Hamburger, 'Reading Representations,' 186-87. For expectations about female sanctity, see Gábor Klaniczay, 'Legends as Life Strategies for Aspirant Saints in the Later Middle 
Ages,' Journal of Folklore Research, 26 (1989), 151-71; Gisela Muschiol, 'Zur Typologie weiblicher Heiliger vom frühen Mittelalter bis zur "Legenda maior," in Das Bild der heiligen Hedwig im Mittelalter und Neuzeit, eds Eckhard Grunewald and Nikolaus Gussone (Munich: Oldenbourg, 1996), 39-54. For the local context, see Teresa Dunin-Wąsowicz, 'Sainte Hedwige et l'hagiographie médiévale polonaise,' in Le cute des saints au XIe-XIIIe siècles, ed. Robert Favreau (Poitiers: University of Poitiers, 1995), 53-61.

37 See Josef Krása and Klaus Kratzsch, 'Beschreibung der Handschrift und kunsthistorische Einordnung der Miniaturen,' in HC2, 9-34.

38 For the originality of the images, see ibid., 22-4.

39 See Jakub Kostowski, 'Das Breslauer Triptychon der Hedwigslegende. Herkunft und Ikonographie,' in Grunewald and Gussone (eds), Das Bild der heiligen Hedwig, 159-82.

40 For Hedwig's historical position, see Joseph Gottschalk, St. Hedwig, Herzogin von Schlesien (Cologne: Böhlau, 1964).

41 This family group is pictured in HC, fol. 10v. For more on this clan, see Herzöge und Heilige: Das Geschlecht der Andechs-Meranier im europäischen Hochmittelalter, eds Josef Kirmeier and Evamaria Brockhoff (Munich: Haus der Bayerischen Geschichte 1993), 66-99. For Elizabeth and her massive influence, see ibid., 131-44; and Elisabeth von Thüringen: Eine europäische Heilige, eds Dieter Blume and Matthias Werner, 2 vols (Petersberg: Imhof, 2007).

42 An event shown in $H C$, fol. 18 r.

43 As in HC2, 74-5.

44 For this convent, see Gottschalk, St. Hedwig, 219-29.

45 These activities largely correspond with the Acts of Corporeal Mercy advocated for lay women and men; see Martina Wehrli-Johns, 'Armenfürsorge, Spitaldienst und neues Büssertum in den frühen Berichten über das Leben der heiligen Elisabeth,' in Blume and Werner (eds), Elisabeth von Thüringen: Aufsätze, 153-63.

46 HC2, 78; discussed by Jung, 'Tactile and Visionary,' 215-16.

47 HC2, 78 .

48 HC2, 88; discussed by Hamburger, Visual and Visionary, 303-5.

49 HC2, 88. Four eighteenth-century flails from the Dominican convent of Unterlinden (Colmar) appear in Krone und Schleier: Kunst aus mittelalterlichen Franenklöstern, ed. Kunst- und Ausstellungshalle der Bundesrepublik Deutschland, Bonn und dem Ruhrlandmuseum Essen (Munich: Hirmer, 2005), 479-80.

50 On the agency of tools and weapons, see Elaine Scarry, The Body in Pain: The Making and Unmaking of the World (New York: Oxford University Press, 1987).

51 This is one of only three images in the manuscript in which Hedwig appears en face. In one $(H C$, fol. 30v), she is again dining alone and lifting a vessel of water to her lips; her husband stands nearby, chiding her for drinking only water, whereupon the liquid turns to wine. In a very different composition ( $H C$, fol. 30r) she assumes the central position among a row of nuns crouching on the ground to grieve for the death of Hedwig's husband. While the other mourners weep, she alone gazes outward, betraying no emotion.

52 HC2, 90; also discussed by Jeffrey F. Hamburger, Nuns as Artists: The Visual Culture of a Medieval Convent (Berkeley, CA: University of California Press, 1997), 174.

53 Cf. Hamburger, 'Reading Representations,' 188-9.

54 HC2, 78.

55 Emily Savage, a presenter at the Agency of Things conference, offered useful insights on the interactive design and function of choir stalls in late medieval churches.

56 HC2, 78.

57 See Uros Cvoro, 'The Present Body, the Absent Body, and the Formless,' Art Journal, 61 (2002), 54-63.

58 HC2, 79.

59 Ibid.

60 HC2, 86.

$61 \mathrm{Ibid}$.

62 Michael Robinson, St. Francis of Assisi: The Legend and the Life (London: Continuum, 1997), 120; Pestilli, 'Apostolic Bare Feet.'

63 The Franciscans came to Silesia only in 1236, seven years before her death; see Gottschalk, St. Hedwig, 208. For expectations of courtly women in Hedwig's milieu, see Sybille Schröder, 'Frauen im europäischen Hochadel des ausgehenden 12. und beginnenden 13. Jahrhunderts. 


\section{The Boots of Saint Hedwig}

Normen und Handlungsspielräume,' in Blume and Werner (eds), Elisabeth von Thüringen: Aufsätze, 27-34.

64 'Kick Off Those Heels! Stars without Shoes,' New York Post, Page Six, 7 May 2014; online edition: http://pagesix.com/2014/05/07/kick-off-those-heels-stars-without-shoes (last consulted 24 October 2016).

65 HC2, 85-7.

66 HC2, 85-6. The episode has its own rubric: Quomodo subito apparuit calciata miraculum.

67 Allison D. Fizzard, 'Shoes, Boots, Leggings, and Cloaks: The Augustinian Canons and Dress in Later Medieval England,' Journal of British Studies, 46 (2007), 245-62.

$68 \mathrm{HC} 2,86$.

69 In the Musée de l'art et d'histoire, Fribourg (Switzerland), dating to c.1470.

70 See Gottschalk, St. Hedwig, 127.

71 A point discussed in Jung, 'Tactile and Visionary,' 237-39.

72 HC2, 94.

73 Ibid.

74 HC2, 154, discussed in Jung, 'Tactile and Visionary', 239-40.

75 On the spread of Hedwig's cult, see Gottschalk, St. Hedwig, 291-315.

76 A similar conclusion was reached, via a different itinerary, by Schleif, 'Hedwig's Ivory Madonna.'

77 A much shorter and differently focused iteration of this paper was presented in a session organized by Alexa Sand and sponsored by the International Center of Medieval Art at the International Congress on Medieval Studies, Kalamazoo, Michigan, May 2014. I am grateful to Grażyna Jurkowlaniec, Kamil Kopania, and their colleagues for providing me occasion to expand and nuance my reflections for the event in Warsaw, and to the editors of this volume for this opportunity to present them in more solid form. 


\section{Index}

‘s-Hertogenbosch: Saint-John Cathedral 139

Abenaes, Salomon born as Alvaro Mendes 28

Actor-Network Theory (ANT) see Latour, Bruno

Aelian (Claudius Aelianus) 23, 28

aesthetics $75-8,158$

agent $6,9-10,12,17,30,52,63,68,76,99$, $120,130,158,160,165-6,177,180,182$; autonomous agent 64 ; human agent 6,63 , 192; non-human agent 11 ; primary agent 6,69 ; secondary agent 6 ; social agent 6 , 10,91

Agnes of Wettin 179

Alain of Lille 153

Alberti, Leon Battista 67; Della pittura 77

Aldobrandini, Giovanni 94

Aldobrandini, Piero 106

Alfonso I of Aragón 97

Alfonso IV of Aragón 54

Alfonso VII 52

Alfonso X 52

Alfonso XI of Castile 51-5, 58-9

Andrew of Hungary 179

Angelini, Bartolomeo 108

Anghiari, Giusto d' 96

anthropology of art 76

Antwerp 17, 117, 119, 122, 131-3, $135,137-40$

Apelles 121

Appadurai, Arjun 9

Aretino, Pietro 104-5

Arezzo 3

Arhardt, Jean-Jacques 175

art nexus 76

August II the Strong of Saxony 166

Augustine of Hippo 10, 78-80, 106; Confessions 78

Auschwitz 175-6

Avignon 51

Bacci, Andrea 17, 30; L'Alicorno 28

Bachelard, Gaston 42
Bamberg 119, 179

Banaś-Maciaszczyk, Jolanta 175

Barbo, Pietro, pope Paul II 91, 96, 98-9

Basel 134

Baxandall, Michael 76

Bayeux Embroidery 152

beauty see also aesthetic 10-11, 22-4, 30, 35, 75-80, 83-4, 104, 166

Beham, Hans Sebald 133

Beneficio di Cristo 106

Bennett, Jane 150

Bentivoglio, Giovanni 96

Bernard of Clairvaux 35

Berry, Jean de 7

Berthold of Regensburg 175

Berthold IV of Andechs 179

Bible 11, 129-137, 139-141; New Testament 130-2, 134-6, 139-40; Old Testament 80, $130,132-3,136$

biographies of objects 98

Blanckart, Alexander 137, 139

Bloemaert, Abraham 139

Boccaccio, Giovanni 104

Bologna see Bentivoglio, Giovanni

Bologni, Girolamo 104

Boodt, Anselmus de 20, 23, 25

Botticelli, Sandro 108

Bourdieu, Pierre 4

Breton, Jules 176

Brieg 178

Bruges 117, 119

Brunschwig, Hieronymus 164-5

Brussels 17, 40, 117, 119, 121, 131

Bruynincx, Antonius 139

Budapest 175,

Buonarroti, Michelangelo 10, 103-12; Childrens' Bacchanal 112; Fury 103; Hercules (statue of) 106; Pietà (for Vittoria Colonna) 112; Punishment of Tityus 103-7, 112; Rape of Ganymede 103-8, 112; Three Heads 103; Zenobia 103

Buonarroto, Michelangelo's brother 106 
Burgos 52, 54; Cistercian abbey of Las Huelgas 9, 51, 53-4; Cristo de Burgos 57

Byrthferth of Ramsey 153

cabinet of curiosity see Wunderkammer Cafaggiolo: Villa Medici 95

Calvin, John 106

Capponi, Neri Gino di 95

Caravaggio, Michelangelo Merisi da 77

Carey, Hilary 146

Carnesecchi, Bernardo di Cristofano 95

Carpi 96

Carruthers, Mary 79, 148, 165

Castiglione, Sabba da 121

Catalanus, Jordanus (Jourdain de Séverac)-24

Catelan, Laurens 24-5

Cavalieri, Tommaso de' 10, 104-5, 107-9, 111

Cellini, Benvenuto 108

Cerda, Fernando de la 53-4

Certeau, Michel de 177

Charlemagne 28

Charles V Habsburg 91, 117, 136

Charles the Bold 28

Chauliac, Guy de 163

Chellini, Giovanni 95

Chigi, Agostino 98

Christian III of Denmark 166

Chua, Liana 7

Church Fathers 35, 106

Clement VII, pope 103, 106

Colle di Val d'Elsa 80-1

Cologne 133, 135, 137, 139

Colonna, Vittoria 10, 1067, 111-12

Commachio 98

Compostela 51-9

Condivi, Ascanio 108

Constantine the Great 19

Copage, Antony 165

Coquatrix, Jacques 57

Coster or Costerus, Frans de 139-40

Croll, Oswald 25

Crophill, John 146

Ctesias 23

Danner, Leonhard 166

Dante, Alighieri 78-81, 104; Divina Commedia 78

Daston, Lorraine 91

Delphi (Apollonian temple) 74

Demaitre, Luke 151

Deruta 110

devotion 8-9, 11, 33, 36-9, 63, 65, 67-8, 183-5, 188-90

Distelberger, Rudolf 17-18

Donatello 95

Dresden 135, 166

Duchamp, Marcel 6
Dürer, Albrecht 10, 117-23; Adam and Eve 121-2; Anthony 119; A Knight 121; Death and the Devil 121; Marys 119; Melencolia I 119, 122; Nemesis 121; Passion 119, 121-2; Saint Eustace 121; Saint Jerome in his Study 119-21; Veronica 119

Durham 146

Eckbert 179

Edward I of England 28

Edward III of England 59

Edward IV of England 27

Eleonora of Aragón 92-3, 97

Elliott, Mark 7

Emser, Hieronymus 135

enchantment 59, 76, 79 see also Gell, Alfred

Enden, Martin van den 139

Enrique IV of Castile 58

Enzinas, Francisco de 131-2

Erasmus of Rotterdam 106, 130

Este de: Alfonso 96; Ercole 96, 98; Isabella 98; Leonello 91

Evans, Robert John Weston 23

Farce of Ávila 58

Fayreford, Thomas 146

Federigo da Montefeltro 98

Fernando IV of Castile 51

Fernando de la Cerda 53-4

Ferrante of Naples 97

Ferrara 91-2, 96, 98

Fiorentino, Rosso 105

Florence 64, 95-7, 103, 108

Fludd, Robert 25

Forteguerri, Carlo 95

Fosster, Robert 165

Francis of Assisi see Saints

Frankfurt 17

Frederick IV of Tyrol 91

Friedrich III Habsburg 158-60

Fries, Christian 29

Fuchs, Hiero 135

Gaddesden, John 149

Gaiger, Jason 64-6

Galen 157

Galle, Cornelis 139

Garnett, Jane 64-5

Gauguin, Paul 176

Gell, Alfred 5-7, 10, 12, 59, 69, 75-9, 158; Art and Agency: An Anthropological Theory 6, 76; The Technology of Enchantment and the Enchantment of Technology (essay) 5, 76

Gelmírez, Diego 55

Gennep, Jaspar van 137, 139

George of Saxony 134

Gertrude of Hungary 179 
Ghelen, Jan van 135

Ghent: Gallilee 37

Ghiberti, Lorenzo 99

Giddens, Anthony 4

Gift 9-10, 28, 64, 65, 92, 103-12, 117-22, $132,174-5$

Giunta, LucAntonio di 133

Gogh, Vincent Van 175-6, 187

Gonzaga: Francesco II 96; Francesco, cardinal 98

Gosden, Chris 5

Graziano, Frank 67-8

Grigg, Robert 121

Groebner, Valentin 118

Grove, Nycholas 165

Guillemeau, Jacques 163

Guizzelmi, Giuliano 63-4, 67-9

Gunther of Leubus 186

Hamburger, Jeffrey 33

Hardy, Thomas 176-7, 185, 187

Hedwig of Silesia 11-12, 173-4, 177-92

Hegel, Georg Wilhelm Friedrich 75

Heidegger, Martin 8, 175-7

Heller, Jakob 122

Henry I the Bearded of Silesia 179, 186

Herkenrode 38

Hippocrates 157

Holbein, Hans the Younger 133-5

Holmes, Megan 64-5

Horenbout, Gerard 37

Huberti, Caspar 139

Impruneta: image of Madonna 64

index 6, 12, 57, 76-7, 190

Ingold, Tim 9, 162

inscription 20, 38, 91-2, 99, 110, 136, 149

inventory $19,26,28,91-3,96,98$, 165,175

ivory $26,28,160,174,179,188-90$

Jerusalem 35

Johann, Margrave of Brandenburg 119

Jones, Peter Murray 146

Kant, Immanuel 76

Kantorowicz, Ernst 58

Keane, Webb 99

Khevenhueller, Johann van 19

Kuhnrath, Heinrich 25

Kunstkammer 9, 17-19, 27, 30-1, 40, 166

La Paz 159

Lamprecht, surnamed 'der Pfaffe' ('the Priest') 20

Landino, Cristoforo 104

Landore, Bérenger de 58

Las Huelgas de Burgos see Burgos
Latour, Bruno 4, 12; Actor-Network Theory (ANT) 4-5

Leenhardt, Maurice 105

Leiden 159

Leo X, pope 96

Lessing, Gotthold Ephraim 11

Leuven 40, 136, 139

Liegnitz 173, 178

Liesvelt: Hansken van 132; Jacob van 132; Bible 132, 135

Limburg, brothers 7

Linehan, Peter 51, 53

Linz 158

London 146, 159-60, 164-5, 177, 178, 185

Louvain see Leuven

Ludwig I of Liegnitz and Brieg 173, 178

Luther, Martin 11, 129-32, 134-5

Maier, Michael 25

Malvasia, Carlo Cesare 106

Manfredi, Carlo Francesco 18-19

Mantovano, Battista 104

Mantua 96

Margaret of Austria 119

Marguerite de Navarre 111

Marini, Andrea 30

Martelli, Niccolò 94

material culture 5, 9, 33, 39, 177

material turn 4, 9, 173, 192

materiality 4, 7-12, 55145

Matthias Corvinus 98

Mauss, Marcel 105, 118

Maximilian I Habsburg 117, 119

Mechelen 9, 33-4, 36-7, 39-41, 117

Medici de' 95, 97-8; Cosimo 28; Francesco I Grand Duke of Tuscany 17, 30; Giuliano 98; Ippolito 103; Lorenzo 96, 98-9; Piero il Gottoso (Piero di Cosimo) 98; Piero lo Sfortunato (Piero di Lorenzo) 98

Meit, Conrad 119

Merleau-Ponty, Maurice 158

Meudon 73-4

Meyssens, Joannes 139

Michelangelo see Buonarroti

Michelet, Jules 42

Middelburch, Henrick Peetersen van

Mierdmans, Steven 135, 137

Milan 95-8

miraculous images 7, 9, 57, 63-7, 69-70

Miseroni, Ottavio 18, 20, 22

mnemonic device 148

Modena 10, 92, 93-4

Mondeville, Henri de 157

Montalto delle Marche 91; Montalto

Reliquary 91-2, 99

Moralejo, Serafín 58

Morgan, David 65 
Nagel, Alexander 106

Naples 81, 83, 97; crucifix in church of Sant'Aniello a Caponapoli 80-2

Narsinghgarh 28

Nead, Lynda 151

Neagley, Linda 152

network 4-6, 9-10, 28-9, 65, 69, 94, $117-18,145,149,153$

Nicholas of Lyra 133

Norwich 146

Nuremberg 9, 26, 117, 122, 135, 165

Nygren, Christopher 68

Olsen, Bjørnar 5

Ovid (Publius Ovidius Naso) 77

Oxford 59, 149, 161

Paracelsus (Theophrastus Bombastus von Hoheneim) 25, 157, 165

Paris 28-9, 53, 73, 106, 117, 150, 166

Parmigianino 77, 106

Parry, Jonathan 105

Pauer, Gyula 175

Paul II, pope see Barbo, Pietro

Pedro IV 52

Petrarch (Francesco Petrarca) 108-10

Pfaff, Nikolaus 20, 26, 30

Philip Augustus of France 179

Philip of Burgundy 28

Philostratus Flavius 24

Physiologus 19, 24, 28

pilgrimage 176; virtual 35

Pinchart, Alexandre 37

Piombo, Sebastiano del 108

Pisa 81,83

Pisano, Giovanni 81, 83

Pleyère, Isaac de 29

Pliny the Elder (Caius Plinius Secundus) 23, 26; Natural History 3

Ponzetto 24

Prague 19-20

Prato 63-4, 69; church of Santo Stefano 68; image of Santa Maria delle Carceri 63-4, 67-9

prosopopoeia $73-4$

Protogenes 121

Quentel, Heinrich 133

Raphael 96

Rashun ar Raschid 28

Raymond II Ebrard of Coimbra 54

Reformation 129, 131-2, 134-5, 140-1

Rembrandt Harmenszoon van Rijn 6

Reni, Guido 106

Rilke, Rainer Maria 10, 73-5, 77-9, 84; Archaic Torso of Apollo (poem) 73
Rodin, Auguste 73, 75

Romano, Marco: crucifix at Colle di Val d'Elsa 80-1

Rome 20, 24, 96, 103, 108, 134-5; Castel Sant'Angelo 135

Rosser, Gervase 64-5

Rovere, Francesco Maria delle 96

Rubin, Miri 33

Rubin, Patricia 95

Rudolf II Habsburg 17-20, 23, 25-6, 166

Rudy, Kathryn M. 35-6

Ruremund, Hans van 135

Ruvoldt, Maria 103

Sacon, Jacob 133

Saint: Bartholomew 188; Cosmas and Damian 158-9;

Edmund, patron saint 152; Elizabeth of Hungary 179; Francis of Assisi 186; George 59; Hedwig of Silesia see Hedwig of Silesia; Jerome 130; John the Baptist 8, 150, 174; John the Apostle 80, 135; Leonard 63; Longinus 80; Margaret of Antioch 150, 153; Mary (Virgin Mary) 38-9, 63-5, 80, 134, 136, 139, 189; Mary Magdalene 39, 80; Peter 150; Stephen 63; Three Magi 149; Vincent 188

Salomon, Xavier 92

San Miniato 95

Sancho IV 52

Sangallo, Giuliano da 63

Sannazaro, Jacopo 104

Schapiro, Meyer 176

Schedel, Hartmann 135

Schier, Bruno 36

Schön, Erhard 133

Schubert, Dietrich 176

Schut, Cornelis 139

Seneca (the Younger) 106

Seville: Virgen de los Reyes 55

Seyff, Hans 158-9

Sforza: Bianca Maria 98; Caterina of Forlì 96; Drusiana 96; Francesco 98; Gian Galeazzo Maria of Milan 97; Ippolita of Calabria 97; Ludovico of Milan 96-8

Shepard, Odell 24

Sherman, William 129

Siena 96

Sixtus IV, pope 96

Sixtus V, pope 91

Smith, Pamela 157

sociable things 93

Stierle, Karlheinz 78

Stöckel, Wolfgang 135

Stoke Dry 152-3 
Strasbourg: Cathedral 175

Strozzi 97, 106; Antonio 95; Filippo 97, 106; Gabriello di Soldo 97

Stuttgart 159

Suger of St Denis 22

Tebaldeo, Antonio 104

Togay, Can 175

Tornabuoni, Giovanni 98

Torrón, Francesco 55

Tournai 55-6

Trexler, Richard 63-5, 69

Trognæsivs, Joachim 139

Trotti, Paulo Antonio 97

Trzebnica 179, 183-4, 186, 188-90

unicorn 9, 17-20, 23-30, 34, 41

Urbino 96

Valori, Francesco 97

Vandenbroeck, Paul 33

Varchi, Benedetto 106, 110

Vasari, Giorgio 3, 104-8; The Lives (Le vite de' più eccellenti pittori, scultori e architettori) 103

Venice 98, 133, 164

Vermeye, Jan Cornelisz 17-20, 23, 30

Vermont 177
Vesalius, Andreas 164-5

Vicenza 91

Vienna 23, 77, 106, 159, 166

Vigevano, Guido da 157

Vinci, Leonardo da 108

Vincidor, Thomas 122

Virgin Mary see Saints

Viterbo 106, 110-1

Vorsterman, Willem 132-6, 138

Voyott 265

Wallis, Faith 146

Walton, Kendall 65-7

Warburg, Aby 41

Warsaw 179

Whiteread, Rachel 185

Wittenberg 132

Woensam, Anton 137

Wolff, Thomas 134

Woodall, John 163

Worm, Olé 29-30

Wrocław 179, 186

Wunderkammer see Kunstkammer

Yeats 41

York 146, 151

Zaragoza 52 


\section{Taylor \& Francis eBooks}

\section{Helping you to choose the right eBooks for your Library}

Add Routledge titles to your library's digital collection today. Taylor and Francis ebooks contains over 50,000 titles in the Humanities, Social Sciences, Behavioural Sciences, Built Environment and Law.

\section{Choose from a range of subject packages or create your own!}

\section{Benefits for you}

》) Free MARC records

》 COUNTER-compliant usage statistics

$\gg$ Flexible purchase and pricing options

》All titles DRM-free.

\section{REQUEST YOUR}

FREE

INSTITUTIONAL

TRIAL TODAY

Free Trials Available

We offer free trials to qualifying academic, corporate and government customers.

\section{Benefits for your user}

»Off-site, anytime access via Athens or referring URL

»Print or copy pages or chapters

》) Full content search

》Bookmark, highlight and annotate text

» Access to thousands of pages of quality research at the click of a button.

eCollections - Choose from over 30 subject eCollections, including:

\begin{tabular}{|l|}
\hline Archaeology \\
\hline Architecture \\
\hline Asian Studies \\
\hline Business \& Management \\
\hline Classical Studies \\
\hline Construction \\
\hline Creative \& Media Arts \\
\hline Criminology \& Criminal Justice \\
\hline Economics \\
\hline Education \\
\hline Energy \\
\hline Engineering \\
\hline English Language \& Linguistics \\
\hline Environment \& Sustainability \\
\hline Geography \\
\hline Health Studies \\
\hline History \\
\hline
\end{tabular}

\begin{tabular}{|l|}
\hline Language Learning \\
\hline Law \\
\hline Literature \\
\hline Media \& Communication \\
\hline Middle East Studies \\
\hline Music \\
\hline Philosophy \\
\hline Planning \\
\hline Politics \\
\hline Psychology \& Mental Health \\
\hline Religion \\
\hline Security \\
\hline Social Work \\
\hline Sociology \\
\hline Sport \\
\hline Theatre \& Performance \\
\hline Tourism, Hospitality \& Events \\
\hline
\end{tabular}

For more information, pricing enquiries or to order a free trial, please contact your local sales team: www.tandfebooks.com/page/sales 